\title{
High Performance Systems
}

\section{Proceedings from the Conference on High Speed Computing}

April 18-21, 1994

\section{Comtriled by}

Manuel B. Vigil

\section{DISCLATMER}

This report was prepered as an account of work sponsoed by an abency of the Uniled Stales Government. Neither the United States Goparament nor any ageacy therofi, nor any of theik employees, makes any warranty, express or implied, or assumes any legal bibitify or Jopponst. bility for the accuracy, completeness, or usefulness of Jng information, apparates, product, of

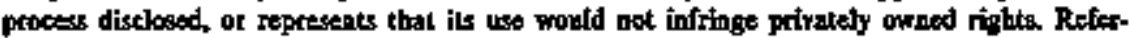
ence berein to any specific commercial produch, processh or service by trade name, tradeantath, mafulacturer, or otherwtse does not necessorlly constitete or Imply its entiorsemend, recrommendation, of fworing by the Uniled States Gonernmeat or any agency thereof. The views: and opinions of awthors expessed herein do not nesessarty slute or reflect those of the United stales Governmeal of any agency thereof. 
$-\cdots \cdots$ 


\section{DISCLAIMER}

Portions of this document may be illegible in electronic image products. Images are produced from the best avaliable original document. 


\section{Table of Contents}

Titie/Author

Page

Virtual Enterprise 2000

1

Fred Kovac, Goodyear Tire and Rubber Co.

Managing User Expectations

15

Tom Maurer, Summit Information Systems

23

Survival of the Fittest

Gary Smaby, SMABY GROUP

Is Economic Competitiveness a Mission?

Hassan Dayem, I ANL

CCC: Criminals Caught by Computing

55

Tom Kraay, Booz, Allen and Hamilton, Inc.

Beyond Lithography: Molecular Manufacturing and the Future of Computing

Ralph Merkle, Xerox PARC

Studying Occupational Hand Disorders

Frank Wilson and George Moore, University of Californix

The High Performance Storage System

Dick Watson, $L L N L$

Quantum Computers and Fredkin Gates

Isaac Chuang, Stanford University

Dynamic Task Migration from SPMD to SIMD Virtual

Machines

James Armstrong, Purdue University

Looking Under the Hood While Driving the Information Highway

Ed Krol, University of Illinois

Internet Demo, "Takin' Fer Out For a Spin Around the Block"

Tom DeBoni, $L L N L$, and Dale Land, $L A N L$

ATOMIC/Myrinet-A New Gigabit LAN Technology

Danny Cohen, Myricom, Inc.

New Frontiers in Wireless Communications

James Stuart, Calling Communications

Speculations on the Structare of Software in the 21st Century 


\title{
HIGH PERFORMANCE SYSTEMS \\ PROCEEDINGS FROM THE CONFERENCE ON \\ HIGH SPEED COMPUTING \\ APRIL 18-21, 1994 \\ Compiled by \\ Manuel B. Vigil
}

\begin{abstract}
ASTRACT
This doctment provides a written compilation of the presentations and viewgraphs from the 1994 Corference on High Speed Computing given at the High Speed Computing Conference, "High Perfomance Systems," held at Glepeden Beach, Oregon, on April 18 through 21, 1994.
\end{abstract}




\title{
VIRTUAL ENTERPRISE 2000
}

\author{
Fred Kovac, Goodyear Tire \& Rubber Co.
}

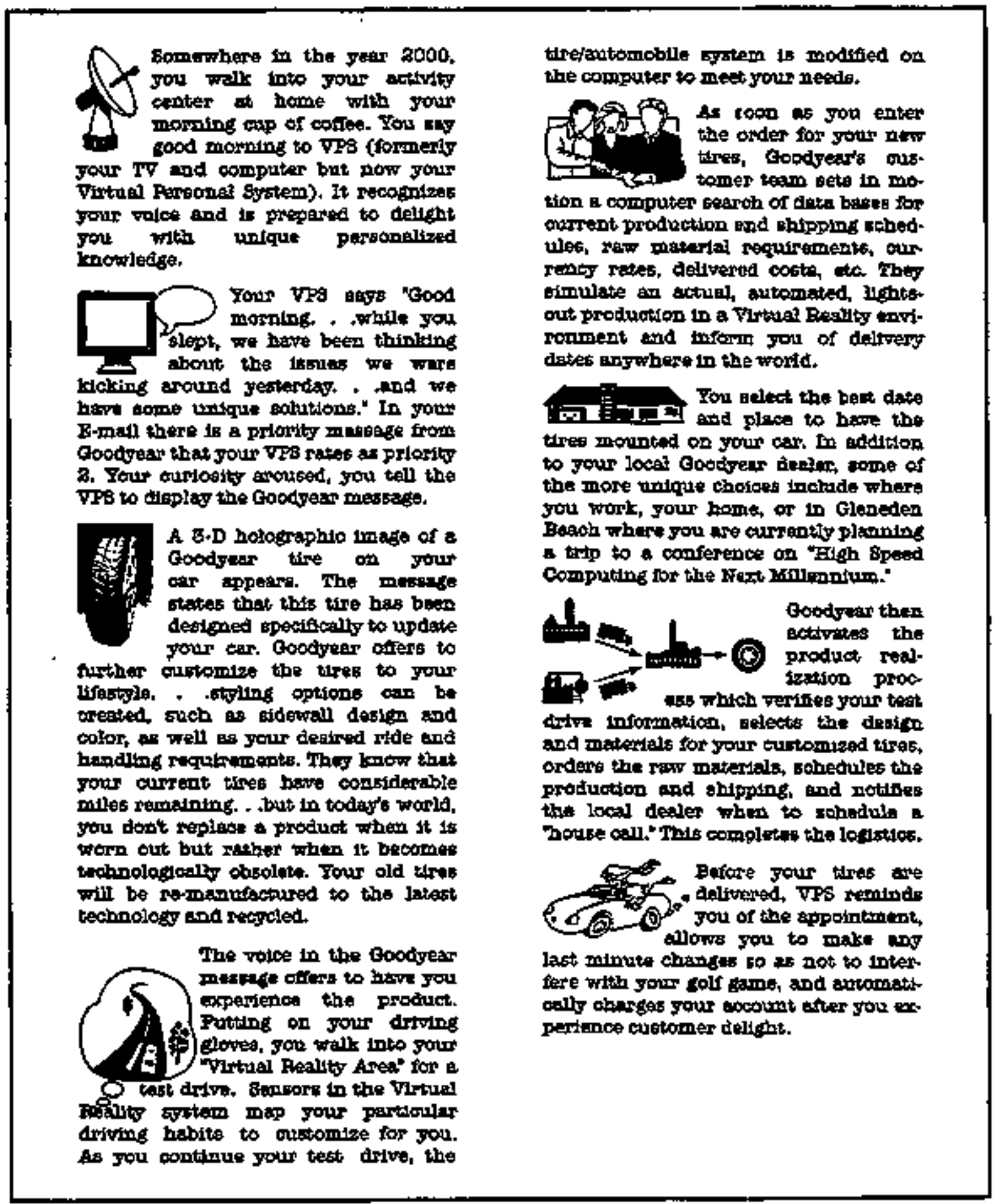




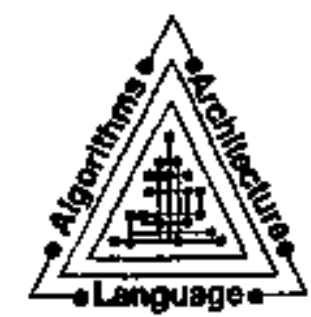

\section{VIfTUAL ENIEAPAISE 296 in}

Corporations are tedises a raptety of moreasindy difleult oballonges as the world approaties the millemก1um:

- OustomenfConsumer Satisfaction/Delient/Logalty

- World Class Quallty and Vajue

- speed ana liesponsiviness (Short Cyale Trimes)

- Changing Demographiaefidfertyles

- Masp Cutomization (Difrerentistion)

- Bhorter Product Itto Cycles

- Innovedire New Froducts

- Inpredrctable Teohnolosy Changes Dyparme Markets

- Thiniz Global . . Gustomire Ioval

- Global Rationalization of Invertments (Bconomies of Bosle, Seope)

- Intense clobal Competition (Froducts/Fnowiedge)

- Goverpmental Fegulations

- Environminti Sastainabimty

- Imployes Commitament

- Bhareholder/Stakeholder Valuo
To meet these challenges sucoesgtulity, a new agile business stivucture called

VIRTOAL BIIBRAPRISE 2000

based on information pystems technoloty, is emerging (Fis 1 ).

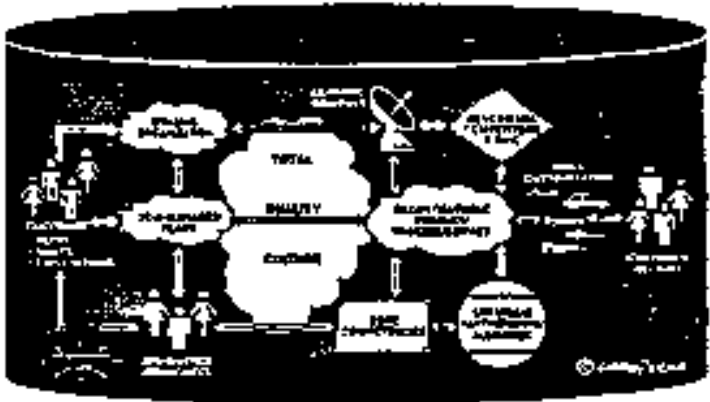

Pis 1 - Virtual fnterpribe 2000

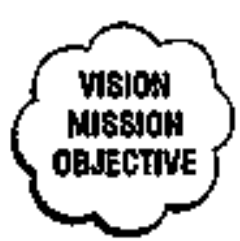

If an onterprite is to compete in the jear 2000, 1ts astontates (employeas) must be motivated by a vistion. Aseociates without a vision resort to extipity. A viston sets forth the ind of operetion the compens wants to be. It should be at agle "stretch," not an textension of the post. A vision for virvual enterprise 2000 is gresented in Fig a.

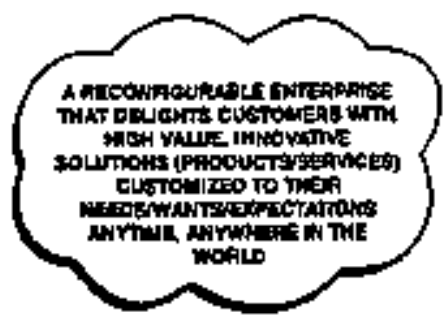

FH Z - EDteaprier VIaion 


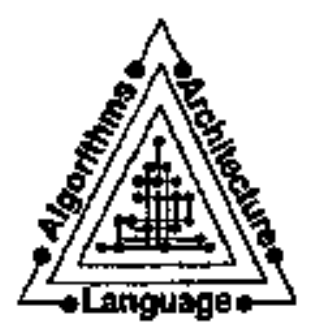

A Fision 18 a leadersbip statement. It focuseg on the future. It can shape the tuture.

While a Fision points atrection, a mission for Virtual Boterpidse 2000 otates purpose (Fis 3).

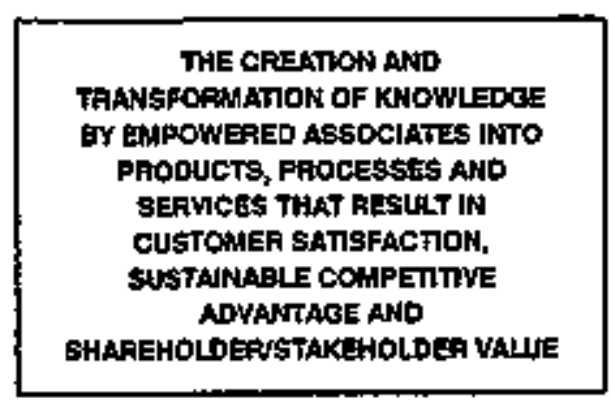

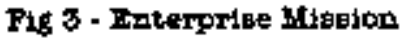

The rision and mission 8et the stage for the objectives of the enterpilse. The example in Fie 4 depicts the obfoctives ortined by stanley c. Gevit for boodyear.

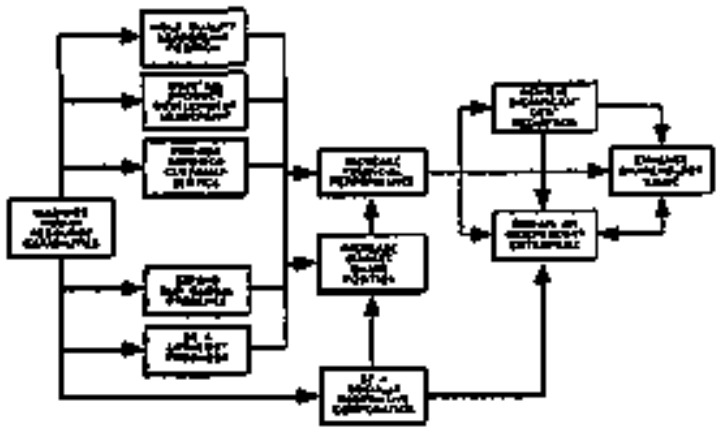

Fis 4 - ghan Ganit Objectsires

Strategles are then deviloped to achieve the objectives. These estab. Wh the companj's stratede focus trom which bustuess planning and resource elloctition can be formulated (His $\$$ ).

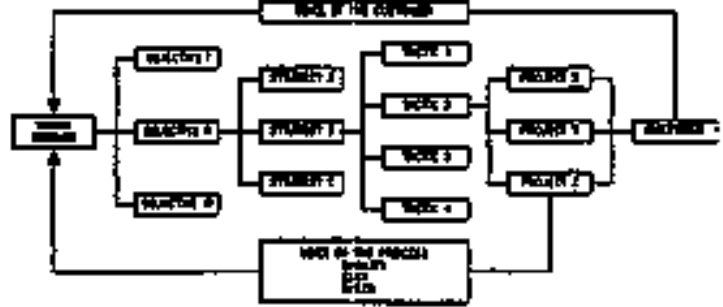

Fis 5 - Stratedo Foous

Deployment is facillitated using techniques such as Hax, Floshin, TQMI, etc.

\section{YIFTUAL ENTMRPRISE $206 n^{\circ}$} Virtual Bnterprise 2000 is basically $\mathrm{a}$ reconflgurable, computen-nderorked, oustomer solutions delivery system.

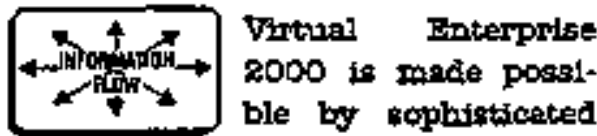
Information systems technolost. The tmerging inteythotionid information infrastracture (III) rowolutionizts: onterprise, othucation and onterteinment (BBE). Information and dete are transparent, seamless and easty accessible any time, eny plase. Systems ecoommodate difital, volol, text, and tinaging as well as differenges in languages, customs, currencies, the Informition aus. ments produts's (Imehatrobios end/or cyberntata). Information leveraging is vital to Vurtual Bntar prise BODO.

Irformetion Age teohnoloby permits

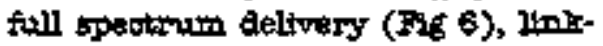
ing information and entipresise goals. 


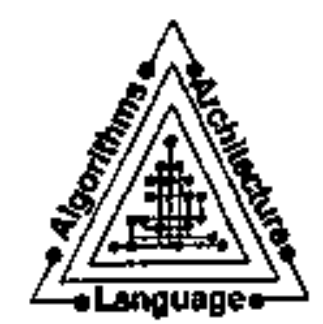

- Client servist + work atations on local aree netrories for distributea computing

- Compact disiks - mim data repositorigs

- Majnframes - enterprsse eeviers for maseive consolidated deta Teponitorises (Iight sizang is bustness critical)

- Modeling and simulation - system visuaitizar

- Global notrotork - universal acvess telepommuntcations system.

- Open systems - phis and play

- Data acquasition at point of omaln - vrarts and all

- Sercimf ana monitoring real-time metidos with opticel scameners

- EDI wath customers, sutphers intaroompany boundaries disappear

- Autonomous asent buted systems - Woll and chew gum

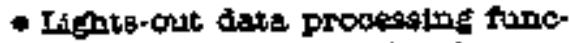
tlops - untoldibed by humar hands

- E-mail gommunications * the freat collaborator $t$ equalies (race, fender, raph are transparemt)

- Infotatingent - informathon can befoth

- Computer commutaing - millions seve on gas!

- System security - hath to low

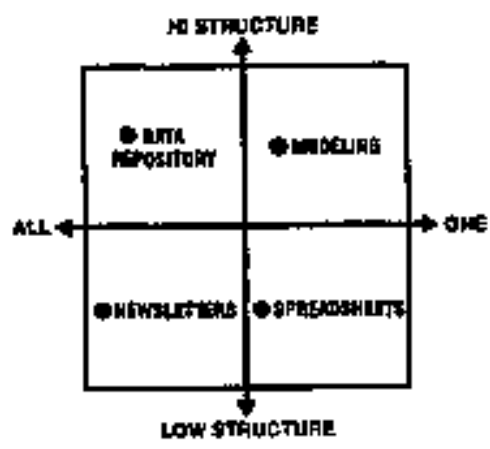

Fie 8 - Information Syctams Infrestiructur

For Virtual Bnterpulse ROOO, reoonfipurable, partire, information er gonomlas potad the buthess hoth. 20 .

- Object alate bases - modular in. formation aystems for rapid custormlzation

- Grouprare - kntrone knoms what everyone lenows, angwhetre

- Ecalable pouter - when you need it, where you need it

- Ziome shopping ard intaractive media for database target marketing - time if money

- Figh bandwifth - volume andjor distance not e constritnt

- Wat screpn sJthems - hang a pictule on a watl

- Ieptope - cridat cand size

- Compler models - renltume 3+D constructs

- "Smart" dats - live intelliefent cystem iniks

- STeural netrwork - cepture the sentus of the human mind 


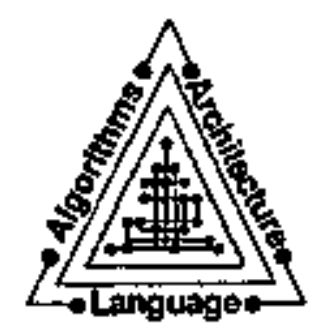

- Voice interactive syathesis - tels to your system syourgistically

- 8ecure catellitio Eyatems - abral internet

- Virtual mobillty - vubicles are information certers linking the espbelt highway and the information highorey

- Personal digttel assjatante and personal communicatore + the otfice is where you are

- Multimedir imajne - Hollywooda pomes to everytay butiness wh the marriage of IV and the computer

- Hazzy lode toftware - not everything is black or whtte

- Masajvely pexalled propessine the body butlder of information Eystkms

- A.I. atpert systems - everyod: can be the best and the brightest

- Viranal heality - immersion into what could be; experiesoing the unknown

- Enobots - tntellifont asststents

In Fis 1, the information flow is represepted by the artomb of chan. nels linting all activities. Through this fromework, the life blood lown end the syotem is nourished.

Virtual Bnterymse 2000 transparenty transforms and tateerates a continuing stream of data chaos into usable information images leading to iroweledge for business Aleciston-making.

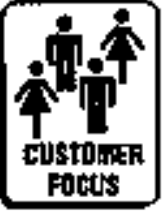

A. Virtual Bnterprise has cutctomer - to - customer tows (Fis 1). That is, marketplace butoss starts with customer needs/vrants/expectations and follows thronigh to customes allight (P46 7). Quelisty is In the cye of the customes. To understand customer needs, a "roloe of the coustomer' process is required. That is, a cus. tomer information Gystem that encompasses everytuing from pointof-gale input . . to to telecommuncations "hot line" . . to on-site, inthe-thetd customers solntions . . . to dobal information hifhwass. Technology pushtmarket pull an be tully expiored for share of market and orowth. The objective is the tight probust for the rifht customas at the refent tilme.

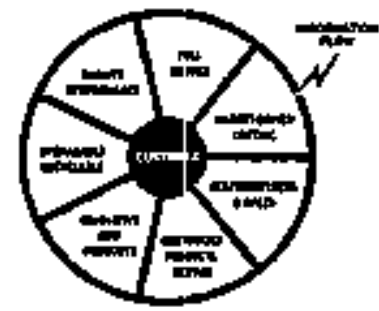

Fis 7 - Custompr Delletht

For anthotpating customer needs and develoying innovarive ner productsi serves, information cystams permit:

- Market mappiag tor nrohe mar iset identitiaztion (F/g B) posttions producte to indicate areas of the mariretplace thet are without protuct or sarvice sorarage. This matrix facliltates a markst-access strategy. 


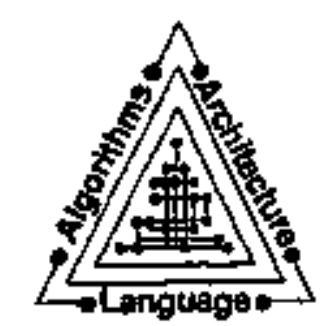

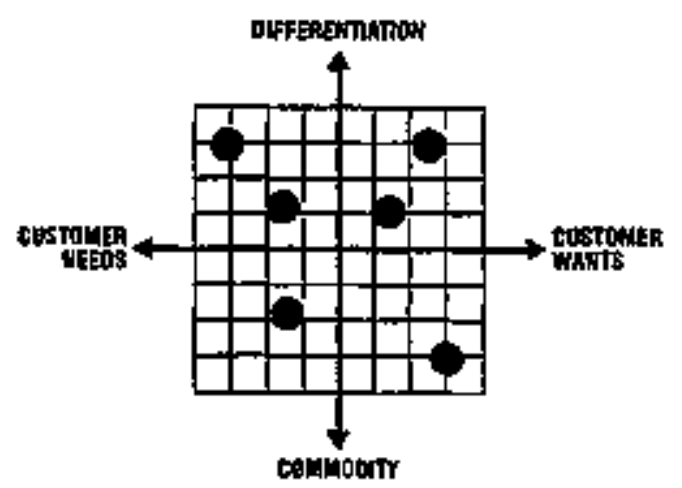

Fig 8 - Market Mapping

- Customer focus soujos, panels and workshops uillize blectronio QD, or gablity function deploy. ment (Fis 9). This database marketing technique etcelishes relationstips betoreen customer requirements and business decistons, e.\$., toobnjoal capabitities.

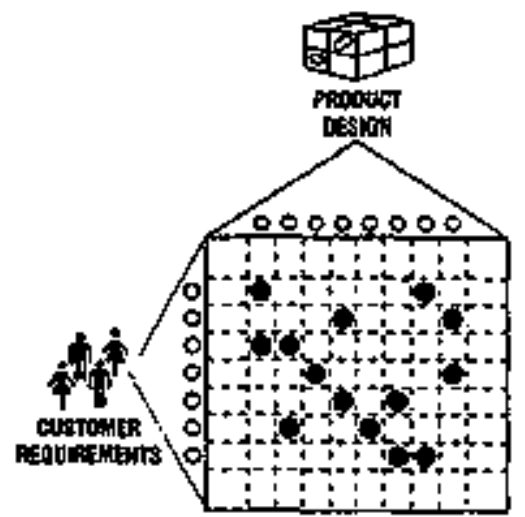

FE 9 - 9

- Techno-business research for technolopicalimarkemplace fore. costing (Fis 10) kinke omerging tathology with emerging waths and ensures that future technol. os satisfies latent axpectations.

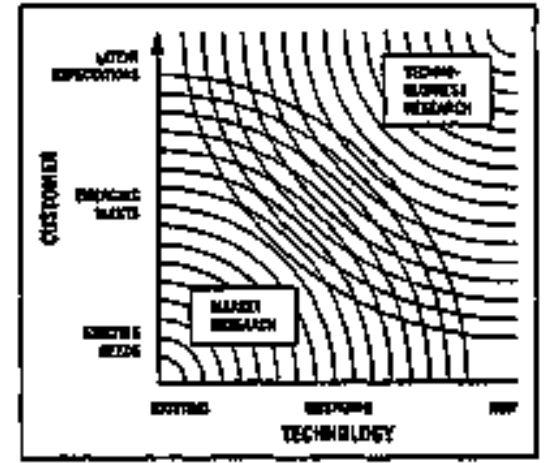

Fis 10-Tachno-Business Researou

- Vutaral Resility in antenta chops benerates ireakthrough products/services (its 11) . Mustomors do not sedily know what they want until they experience it. creating the experience con tre ate the nemaी.

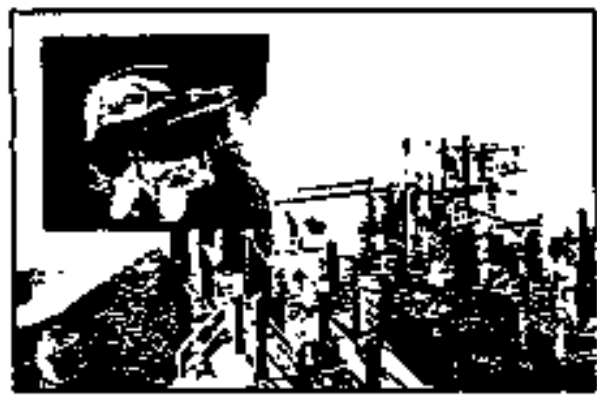

F\& 11 - Virtuel Reality

- Anabrtical Heuristic Protocol (AFI) oymthesizes the information obtained trom Market Mop

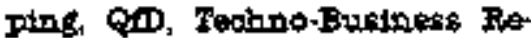
seaptih and Vuttial Reallty. Com. bined with aseoclates' exporthe. AFP (FiE 12) creates Alstinctive forms of knowiedge that predict future trends, clarify common catuses, assess external anvironments, screen ideas and pr. orltize tactios to ment strategic objectives. 


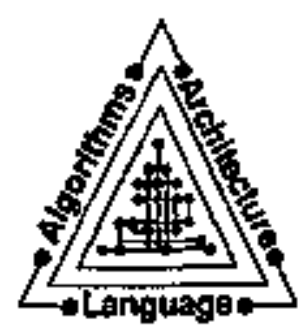

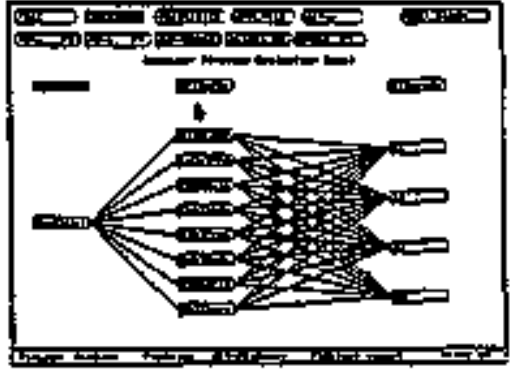

Fis di - Anslyrical Henaristio Protood

Ieveraging the marketplace is a strength of Virtual Interprse 2000 .

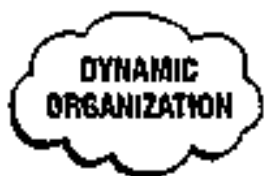

Virtial Entarparte 2000 consists of a Aat, Dexole orfanizational structare (315 1). The history of organizational strinctures has bath worhationary . . . from vertical to hortzontal ... With a eratual reduation of levels in the hiesarchy resulting In an locreased span of control. The epan of control has moved over time from a low of oxe-on-obe reporting to 7 , then 56 and towrarde 100. This pyen will continue to increask. Now, manasers are leaders (listen .... learn . . . and lead) for doing the rithe thines, and assoclates are empowered to do things Iifht (I3E 13).

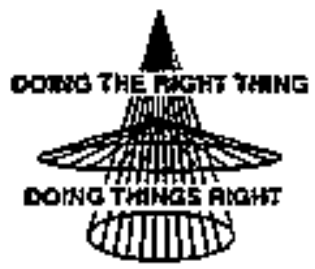

Fig 13 - Leteral Hierarcty
The organization is everyone. Hitech ranaping provides an environmont for astotiates to porform at their best for maximum ortoniza. tionel atience.

Just as form followe turction, structare follows stretegy. Injminathon of a noy-ralue-added blerarchy Is made possible through advanced information systems, e.s., proupware (erreryone knowrs what everyorre knows).

The result is a sense of urgency and quick responsiveness to turn every challonge Into an opportanity end supply rapld solutions to customers. speed is a competitiv advantage and drectly relates to informgtion cyctems terinnolosy.

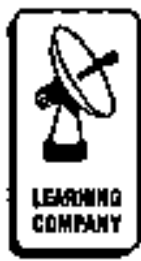

Corporats stratep for competitivo advantedo has expanded from the concepts of rew materyal access and essets utilization to knowledge power. Today, learning is whe rolin sorurce of sustajable competiture adrantage. Once the enverprise moves trom a ricld heram chy to a terible organizational structure, it gains the potential to become a leernins compreny (Fif 1). Information systems technoloty makes it achiovelole. The informe. thon hichwisy enubles assotiates to gain internal and externel perspipat t1Fes and state-of-the-sciends knowtl. edge. No longer do communidations orteinate from one's immedilate 


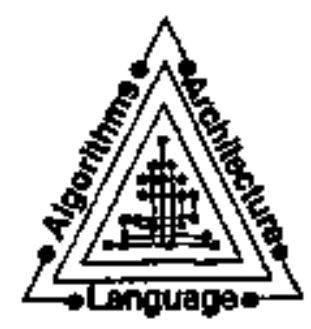

manager but from anpone, enywhere globelly. Information-Hch systerins permit everyone to butld intrastauchure, ldentity options, add exportibe trom other 1ndustries, and gain outside viewpoints. Bveryone is a plobal networker (gatelkeper). Unlimited inpits and synergistic collaborations define the learning corrpang (Fig 14).

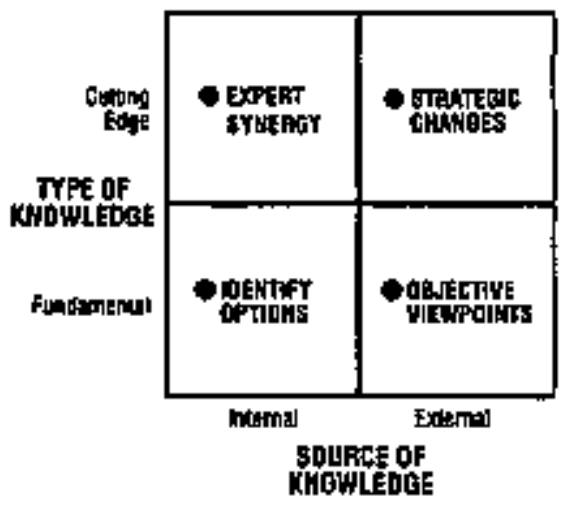

Pus 14 - A Learning Company

Challenges sucb as these sare now tackled routinety:

- Ideatifying critics sucoess teo tors, value-adiled actifties and or cost drivers anywhere in the value chain

- Cluster sharing across portfollos

- Accessing consullentre' serwices

- Conduetine technology assess. ments, especially envitonmental

NIE (not IDvented herre) is creatily zanimized or ellminated through atracegre use of information sys. tems.
A leaming tompany saclitiates the apquistition of knowledge and contimuously transforms 1tuself. A learrnint compang bulde data repositoTies containine technical, market.

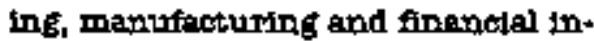
formatron. A learning compery tap. ture日 knowledge in expert bystems. These intellemual astets can bo as valuable as real properties (plants).

A learning cowiting leverages knowled end empowers assoct. ates. Som mathaderial functions in the Invalligent tinterpilse will be pertormed by learning spedialtsts or human resources fecilltators.

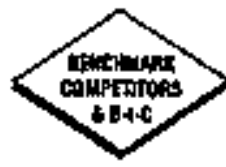

Benchmarking is part of a learning company. Benchmariding broedly sovers com. petitive assessmeat and best prac. thoes, any inaustify (Bis 2)

Benchmarking is essential for:

- Bujlaing gustalmable advantage over competition

- Oatsourcins for best-1a-class

- Eariy warning gystem to prerent. surprises

- Malmta1nitig an external focus

Benchmarising joentifies pobal competition incinding:

- Other producers

- Emsrang technologies

- Sulbstate products 


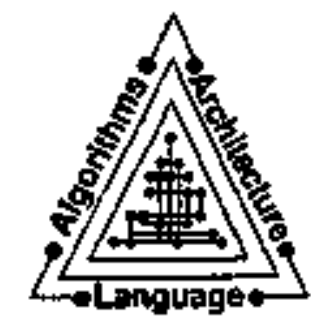

Benchmarleine infolves info-tecth in. clualing:

- Seercinting on the information bithway with knobots (industryt academia/sovernment)

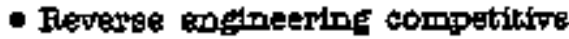
profucte (by computer)

- Fatent mapping to pinpoint flture focus and predict future competitive probuets

Eenchmarkfing should also inchade interual self-assessment, or enter prise anatysis. This inoludes identityol atrungths/weaknesses, core competenoles and orgenizational houlth.

Fey metries measure jroductivity and prostess, mot activity. Mithiles for bechbmarletns apility are grouped as follows:

- External (customer) - customer complaints, proluct performance, averoge product age, etc.

- Intermal (assoclates) - nal per associate, profit par associate, aterese of networing, percent of profit from new products, ash now, concept-to-HOI, etc.

Sophisticated benthmarking technlques can include:

- Teshologyal foresasting, o.E., normative

- Modeling of change

- Alternative scesarios of future competitive enolronments

These techniques our bring foture Dompetitive threats one strategic opportionities into focus and provide tholoty road maps.

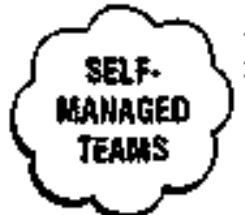

Bilf-manager, eross. functhonal teams are replacine Fitio hiaranchies in the Virtual Enterprise (Fig 1). As corporate sturactures "gtot horizontal," teows dissolve tunctional walls. Toams are bustenese unths . . . minilature learnint ofmpanies . . . they have a viston, mission and objecthores. . they establish lateral inteoration, permititiof funotions to operate concurrectis, not tequentially ... they heve responslbilities and 20xountabilities . . . they maks decisions. The function by means or informition systems. Thedr tefo-teoh tools inoluate:

- Instantaneour teilecomminicathons systems

- Globel teleconferencinÉ

- Global date repastories

- Unrestricted information Dow

- Statistically desiened experiments

- Criadeal patth Aow bartiog

- Value gap anxysis

- Ferformance pretictsons

- sumulations

- Modellog

- Interactive axpert ngetems

Technoloty teanis, for texample, cres. ate, engineer, butld and evaluate new products on the computer atill. jains an intefrated knowledge not. work. 


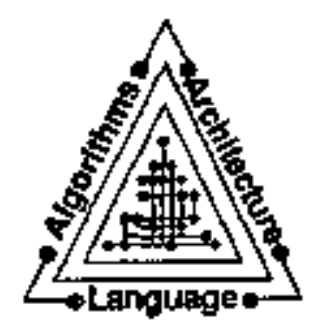

Antificial intellifance permits oomguter diagnostic systems to eflect texhnolocy trantser and resolve challenges (problems) anywhere in the process writh a sense of ur fency. input symptoms and output solu. tions (prowltized options) with feedback are tilnstrated do Fis 15.

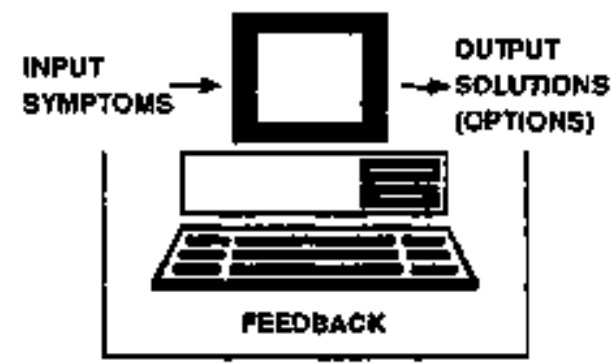

Fis 15 - Dia\&nostic Bjstems

Tham formation is 2 solenoe. For amplis, uting Vidd Ërrmann's left breiniright brain techniques, diversity and team success can be busit-in (Fis 16).

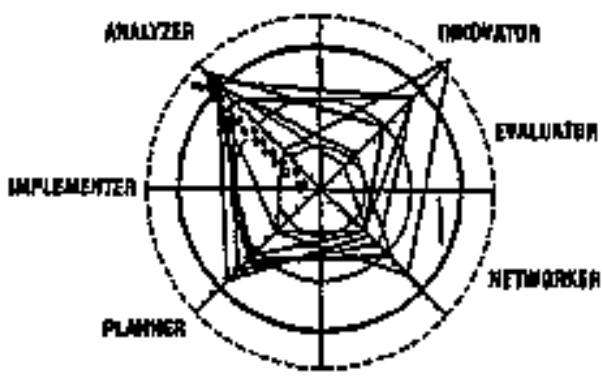

Fid 16 - A Whole Brag" Team

Teatios should be structured for indtvidual excellence and be composed of innoratons, etaluators, network. ers, plenners, troplementers, san1yzers, etc., in sdattion to being moultidisctpitnary and toterentturgl. This a be called THAMAGLITY.
To madmite byors term buslding is netcossary (Fis 17).

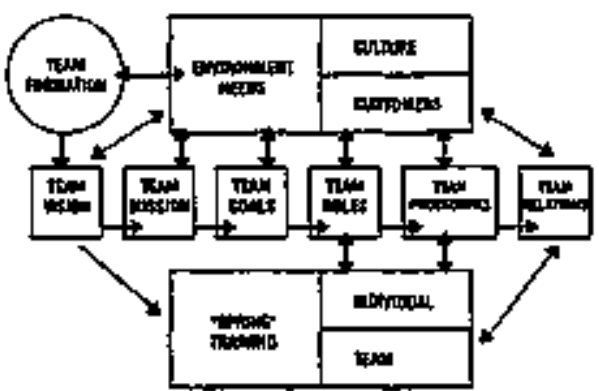

Pis 17 - Team Eusiding Model

Teambased orfanizations interact more with customers to galn insiect into thetr needs/wants/expectations. In addition to eross-functional ceams, the Virtual Bnterprise thrives on cross-0orporate trams with members from customens andjor suppliers andos networied companles. LANs and WANs facllsthe team operations.

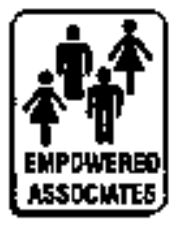

Belf-znanaged teams with partipipatory decision. making empower associates (Ft 1). Informa. won now empowers as. sociates. Bmpowered associates also result from a flater hieretrehy.

Assocjates' aommitment is strengtineced by:

- Irist (everyone wants to do a sood job)

- Flather hterearthy composed of leader-cataches who motivate and enerpize 


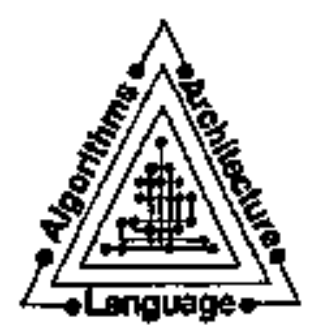

Empowerment is the opporturity for assoclates to declde what needs to be done and discipline themselves to do it. Bumanetios catalyzes thits process. Eumaneties is a symerty of knowleago-assoofates and computer coscultive sballs.

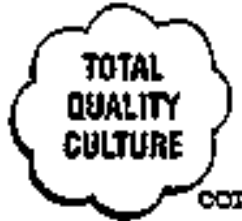

The phllosophy, be1lefs, behavior, and sharea values of an orfentestion are jts Virtual Entergorise (Fis 1) has a to. tal qualita culture (TQC). Thatever the terminology afopted, it is a mossure of the organzation's health. TQC Involves all asioclates at all facilities worldwide. TQC reflects the puallty of vorat life. Tho means moring from problemoriented to vision-led . . . trom making and seliting products to finding thd satisfying needs . . . a leanning company . . trom solving problems

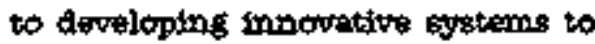
prevent problews . . f from theoldng quality to butlding-ith quality . . from a hierarchy to networlding . . . from eqguentlal to concurrent $+\ldots$ from tunctional silos to selfmaneged teams . . from control to empowerment . . . from internally focused to customerstocused. TQC means re-engineexing around proceqes, not functions . . Alowchart ing the job to diminate non-value aded steps . + + rotrotingtiog the job to Identify opportinititis for iroprovement * . . and fod forward/feedback trom customors.
- Atmosphere of Aversib for max+mizing assooiate symerts and innoration

- A creative entrironment with job assignments that are truly challenging and epriching (mide expecteidomis)

- Cobtanuing educaldon apd trata. Inf for continuous personal and orfanizational improvement (muitimedie isarning)

- Brond-hena joto descriptlons (If ang)

- Clear objectives (linked to cor porate and bustmess unt objecthiss) with performanoe appratsal (major responsibilitios, performance standards)

- El-tech tools with high bandwoth

- Eudfet responsibitities

- Panticipatory dectsion-making through froupwere

- Opportunity for entrepometri ship (e,k., Alsertilonary funding moniles)

- Reward and recognition, Inoluding oelebrations

- Conperpath informetion and "lateral promotion B"

- Sucossion planming criterla

- Work-and-family programs (flex10le work hours, job shaping. work-at-bome, work-at-customers, etc.)

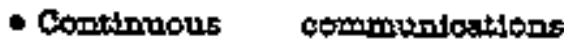
and information for (tally knowiedgeable on the corporate vision, oblectivas, strategles) 


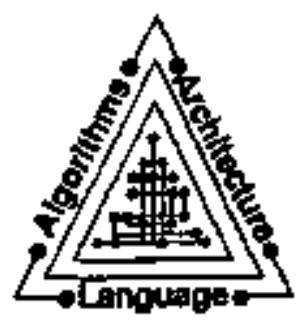

TQc theans bondaryless informathon fow, TQC mean: atworsty for gymerty. TQC molns trugt betheen associlates.

\section{$P$ cone V VItoal Bntewgriso COMPETENCIES 2000 is butt upon ith oore competencles} (H1) 1). Cor oompetencies are the collective 10taring in the offonizatron. Core oompetancies enable a company to roming independent enterpryse. Cor conpetenoies and what a compang does very well . . + preferably bether than the competitiop. . . and passtbly better than angone efse in the world.

In addition to THFiss, Goodyear has ten other core competencies. Just three, as examples:

- gIOBal SIratger (Includas Think Global . . Customize Io. 식)

- Domination of FI-TRCE RACTES (also butilds "sence of urgency")

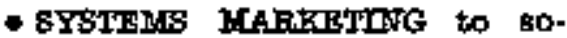
phisticitesa biteah oustomers (e.g., vebicie manufacturers)

In areas where a company lactrs core competencies, it often outsouroes or collaborates for exper tise. The ability to do this is a cose

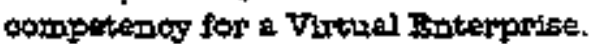
Thes: activitios criatio strateple partustrips and alliances.

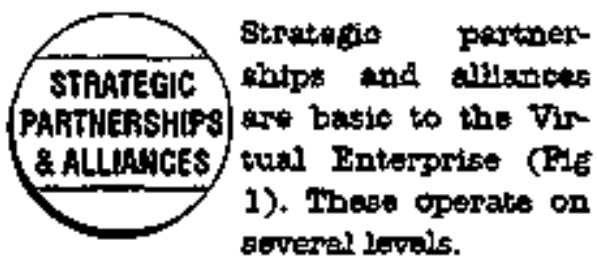

- Strategle partherships axe estab. lished with custcomers and suppiters as a basks for lonserange planning in a winhin combinethon. This is oftem essintial for customer logralty.

- Alianoes andior joint vantres are often formed to penetrate a new teographte market or to enter a new field where adaitional core competencies are required. These collakorations often involve letrepasing tecksioloty or core competenales on a slobal basis. Goodrear joint rentures, for expmple, inohude Bouth Pacife Tyres (Austrella) and South Asia Tyros Inraited (InAila).

- Knowleds relationships with acadimina andor forammentel entities expana technology ana bustinass coppobilities.

These collaborations demend eleotrome partnering through informa-

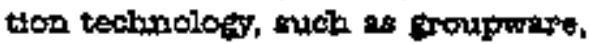
FDI, etc.

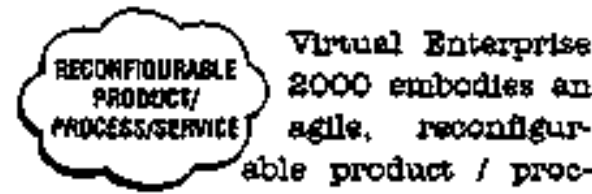
ess $f$ sivilce (피 1). Aflle and reconfourable imply the capabiluty to contimually restructure everyohing including resoluredrs with other 


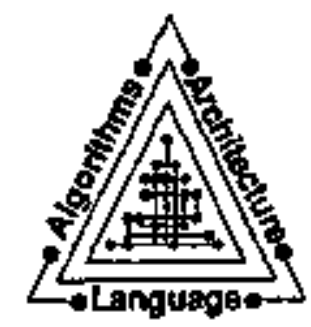

Domparies to achleve tustomer sat. isfaction, Eustainable competstive advantase and shareholder / stakeholder palue in an environment of continuzous ohange. Orfentzations oan be reoonflgurable on an annirtel, montbly, weklky, daily, oren hourly besis. It is the elbility to thrtve on constant change. Open systems are essential in a recontigurable envirosment.

Recomilfurable means maximinting quatity; cost and speed; knowledge of the marketplace; oreatrve enviropments; continuous seareh for new materials; rapid project selectori strategic resource allocation and robust reliablity. Reconfigur. able requites relentless cost improvement over the jrobact life oycle while reteining quality impera. thes. Long-term high-rohume products comrodities. There is a continuous stoeam of tancrative new products and terfble mamufacturing processtos. Global locintias enabite a consumer orAlez to instan. taneoushy triffer compopete activity beok to raw materials sourcles, $10 w$ ost differentitution, value priding. partnerships with complementary companies, etc.

A reconftgurable Virtual Entarprise is a solution destrecy oysterin for oustomers.

A reconfigurable Virtual Bnterpise sen itlight sustomers with high value, innorative solutions (prod. ucts/berfices) customized to their applusations (needshants/expestations) erytime, anywbere in the world.

A Virrual Enterprise keveres change, and, beneiltis from dheos.

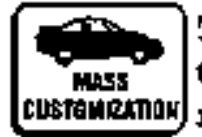

The result is mess ous. tomization . . . tultimatie custankenar market begmentation... jov cost product differentisetion with potential deliverables of one (Big 1).

This stratede follty is the pority of fesence for customer debght and logelity.

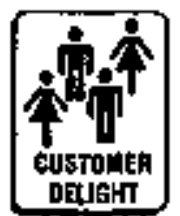

Customer delifht then is real (or percetred) value exceesing expotations with zero mustomer ompleints (Fis 2). Cus tomer delight resulks when dompspies realizit they are selling valuebosed solutions, not products (Bis 18).

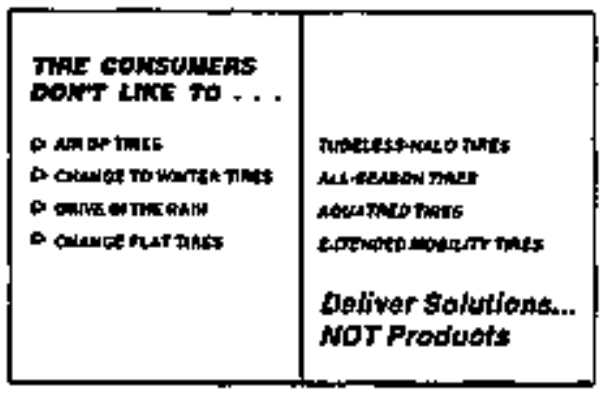

F18 IB - 8el2 8olution: 


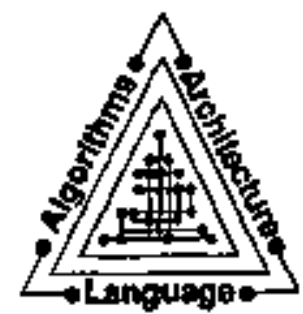

VIRTUAI

ENIERPAISE

$28 \times 6)$

The basic components of Virtual Fnterprise 8000 :

- VistonMLissionNObjectives

- Customer Focus

- Totaj Quality Culoura

- Agrie, fieconfigurable Bystems

- Plexdbje, Plat Organdzation

- DAverse, Fimpowered Associates

- Self-Magraged Teams

- Ieerning Company

- Benchmaricing

- Core Oomptiandes

- Strategic Partnerships and Alliances

- Mass Qustomization

- Global Btrategy

These components are intertwined. They are unified, epergized, end wired" for aglity by information systems technology. Being agle, a Virtual Butarprise an only be charseterized, not defined.

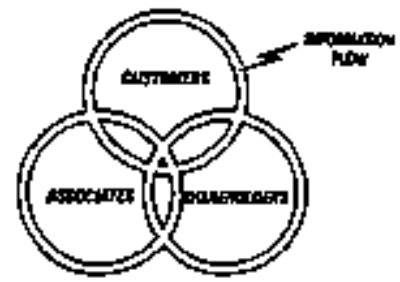

Fif $19 \cdot$ Corporate Symbioris

Assoctates batisfy customers; custorners proride shireholders value; shareholders support essociates (Fis 19).

The VIETUAL BNTLRFRTS 2000 leverages this comporate symbiosis. 


\section{MANAGING \\ USER EXPECTATIONS}

Tom Massrer, Summit Information Systems

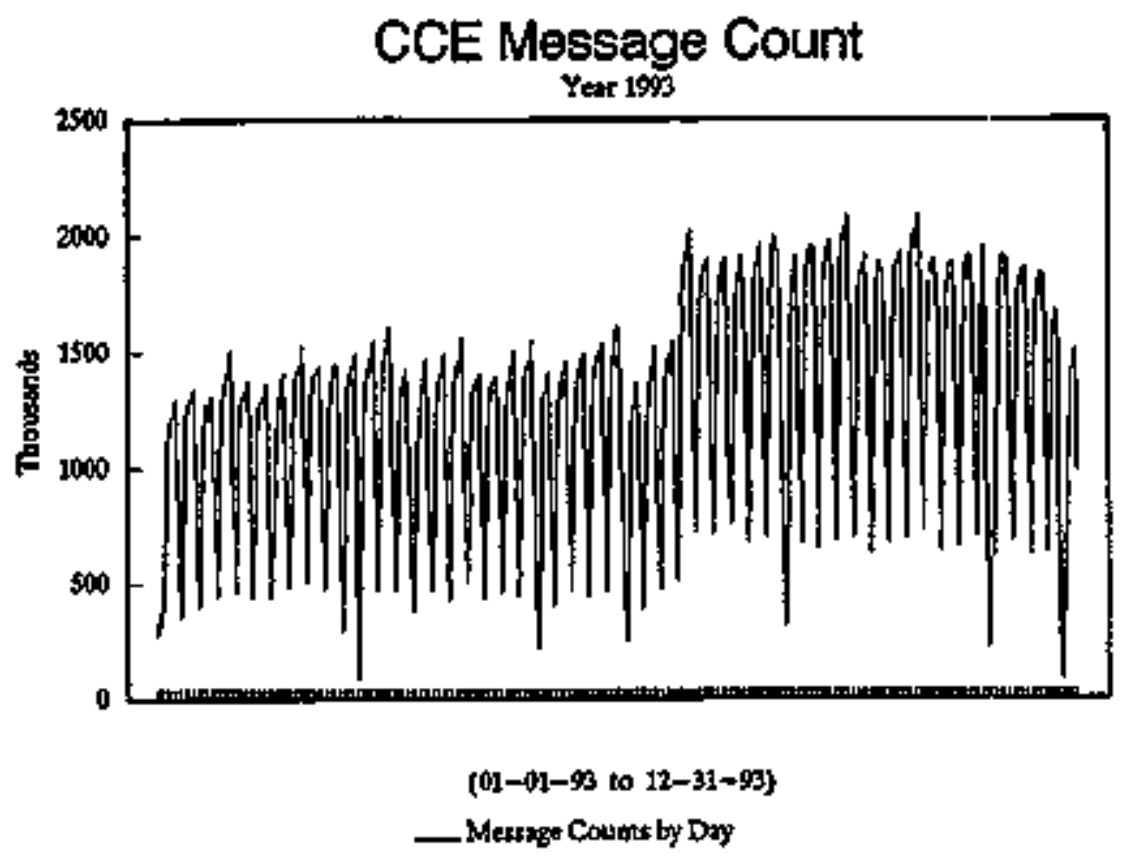

HIGH PERFORMANCE COMPUTING

IS DEFINED BY THE CUSTOMER'S

EXPECTATIONS 


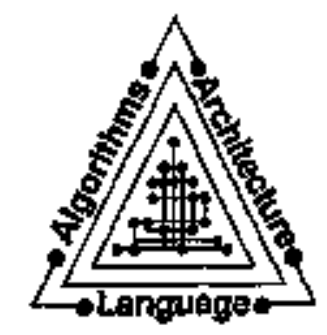

\section{TECHNICAL PARAMETERS}

- RESPONSE TIME

- CAPACITY

- AVAILABILITY

- RELIABILITY

- RECOVERABILITY

- SECURITY

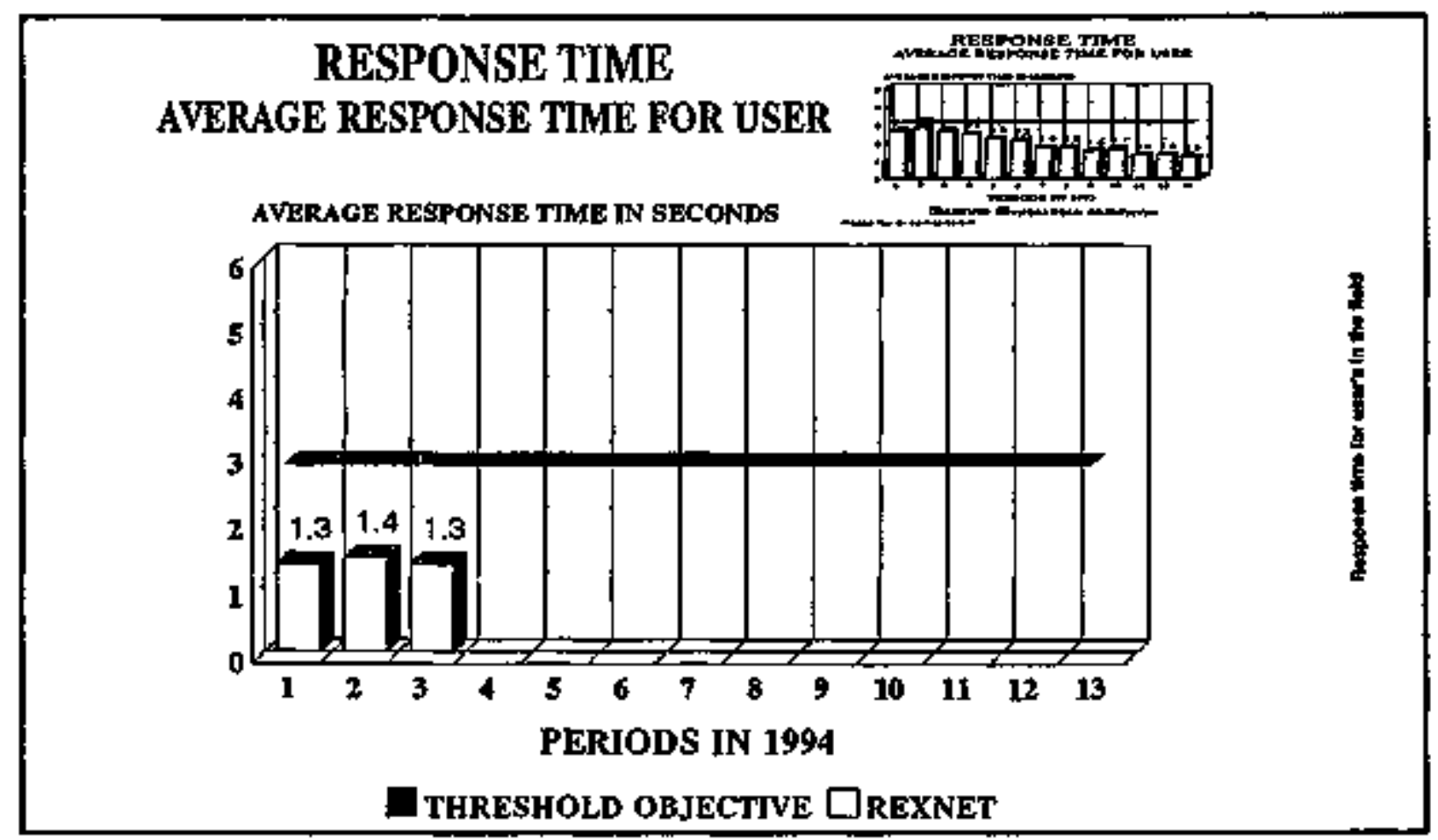




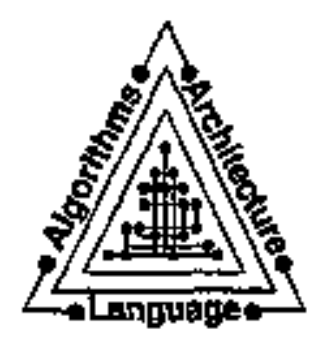

\section{BUSINESS PARAMETERS}

- pRIMARY NEeDS

- EASE OF CHANGe

- COST TO OPERATE/MAINTAIN

- TOUCH/FEEL

- AD HOC REQUIREMENTS

\section{MANAGING THE EXPECTATION}

- CUSTOMER SUPPLIER AGREEMENTS

- IDENTIFY CRITICAL PROCESSES

- SERVICE REPORT CARDS

- KEY MEASURES

- CUSTOMER SURVEYS

- bUSiness PLANNING PARTNER

- SYSTEMS OWNERS

- MATCHING SUPPLIERS TO THE TASK 


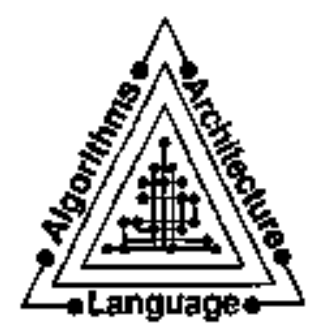

\section{THE QUALITY CYCLE}

- IDENTIFY IMPROVEMENT OPPORTUNITIES

- IDENTIFY KEY CUSTOMERS/SUPPLIERS

- AGREE ON REQUIREMENTS

- DESCRIBE CURRENT PROCESS

- IDENTIFY THE GAPS

- DETERMINE R00T CAUSES

- DEVELOP/IMPLEMENT SOLUTIONS

- MEASURE AND MONITOR

MONITORING KEY MEASURES

DRIVES IMPROVEMENT 


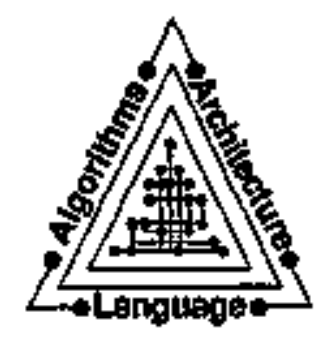

\section{Model 204 Resource Utilization since AM204+BM204 merge} processor cycles and storage reads per transaction

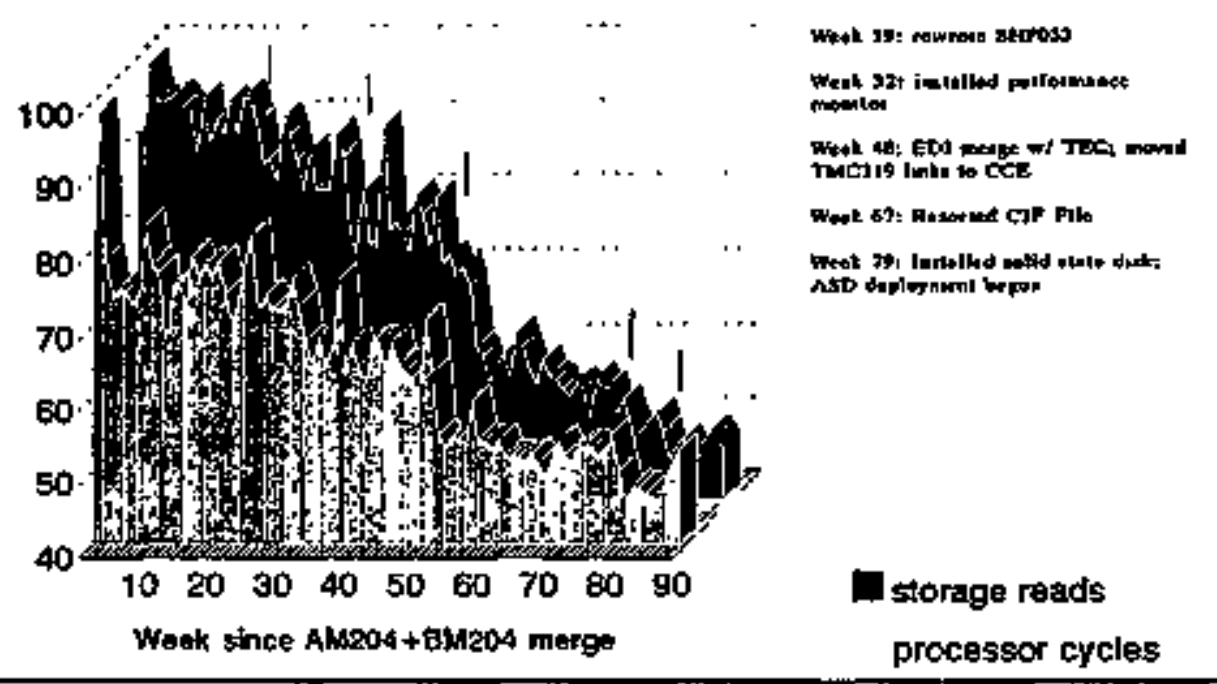

CKSMMS RESFONSE TIME FOA STOFE AND FOFWARD SHSTEM

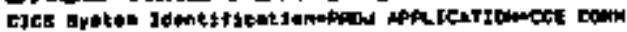

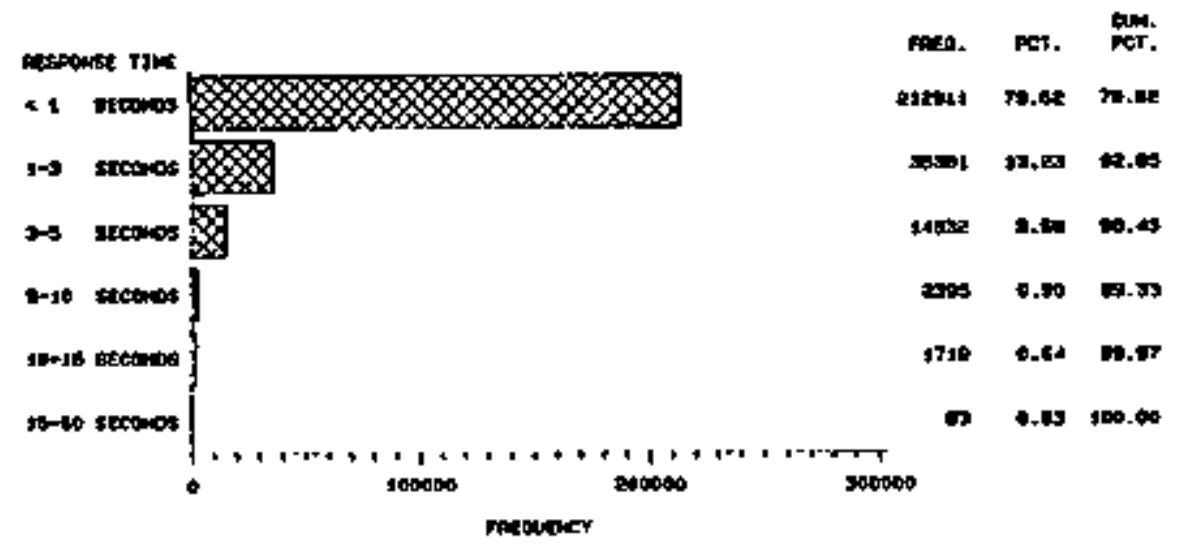



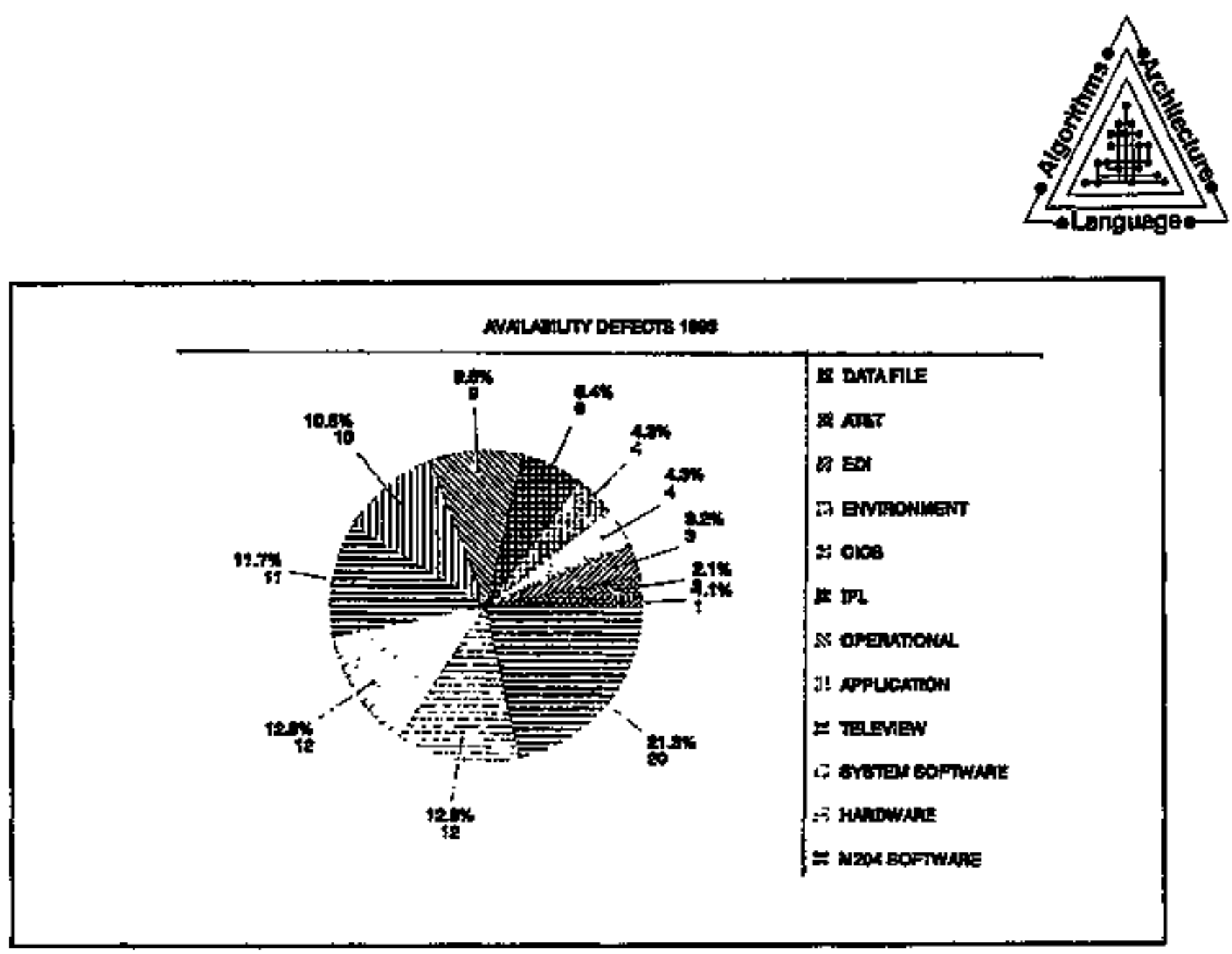

\section{FLASH CALL STATISTICS 1994}

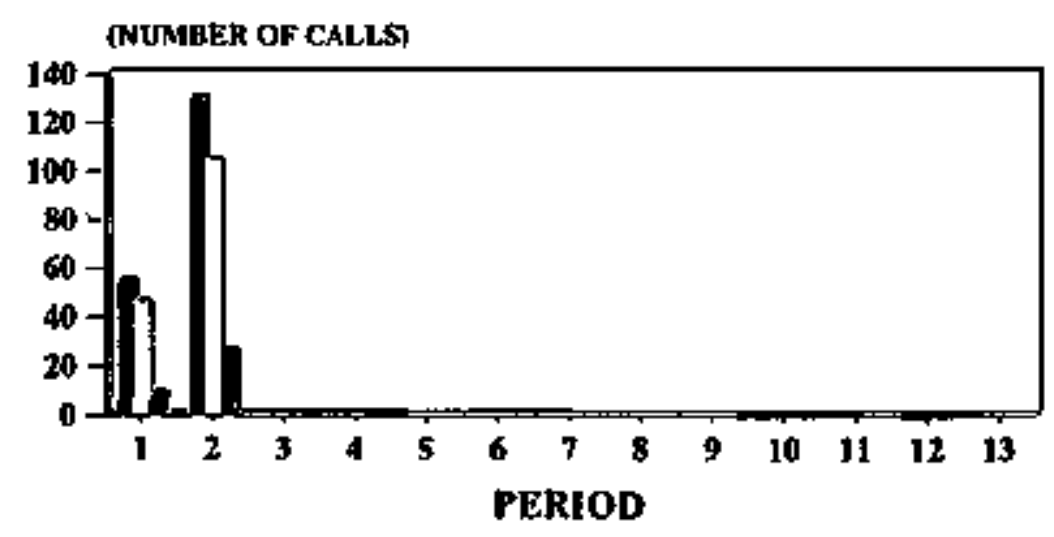

Call statistics

total calls

RESOLVED BY FLASH

ESCALATED TO 2ND LEVEL 


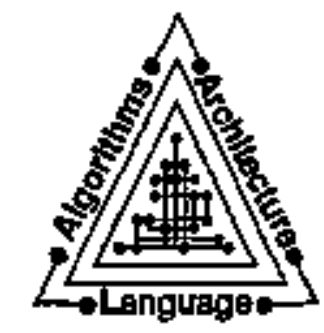

\section{FINAL THOUGHTS.}

- CUSTOMERS PARTICIPATE THROUGHOUT

- NO MAGIC SOLUTIONS

- COSTING MECHANISMS CRITICAL

- PERCEPTION SENSING ONGOING 


\section{Survival of the Fittest}

Gary Smaby, SMABY GROUPS

\section{Game Plan}

$\checkmark$ Definitional Dilemma

$\checkmark$ Market Snapshot

$\checkmark$ A New Paradigm

$\checkmark$ Outlook for the 1990's

$\checkmark$ Emerging Applications

$\checkmark$ Q\&A

\section{ISLA MUJERES - MINISUPER}




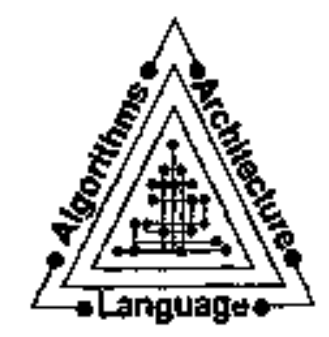

\section{Supercomputer Market \\ Leading Enterprise Vendors} 564 Systems

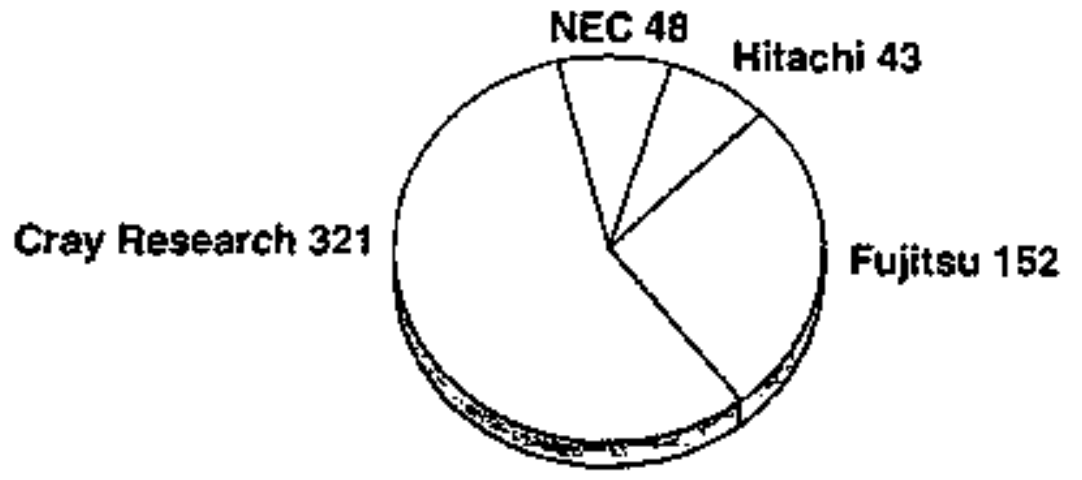

Total System Inatallatlens / Worldwide

\section{Supercomputer Market Scientifie/Engineering/Technical $\$ 2.15$ Billion}

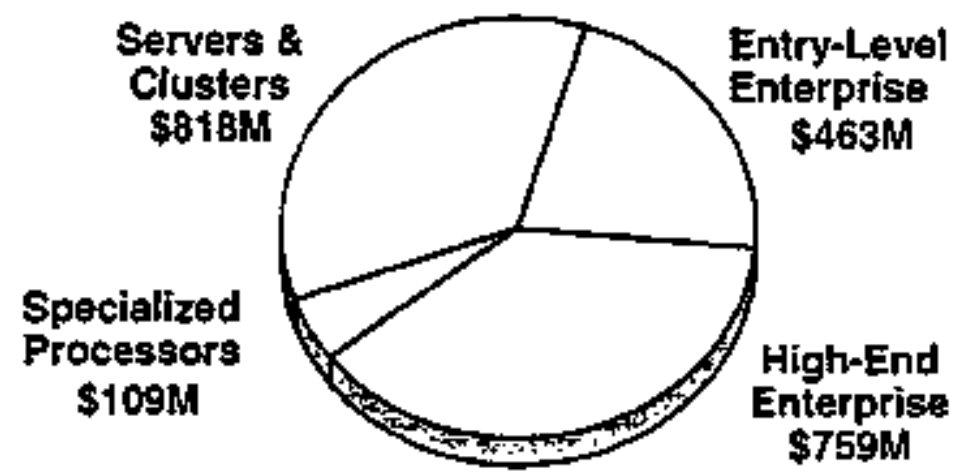

Total Worldwkte Factory Revenues - Hardware 


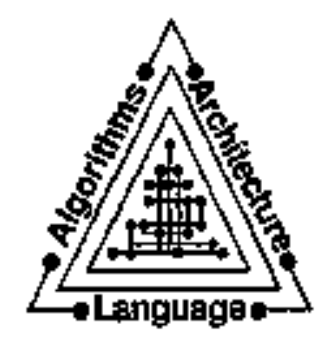

\section{Supercomputer Market}

Scientific/Engineering/Tochnical 1992 to 1993

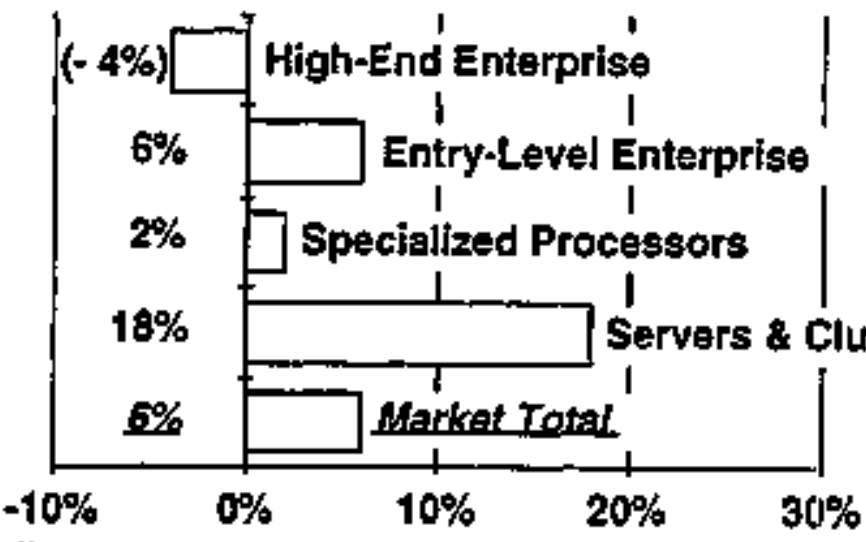

\section{MPP Market Leaders}

S/ET and Commercial Database $\$ 600$ Million

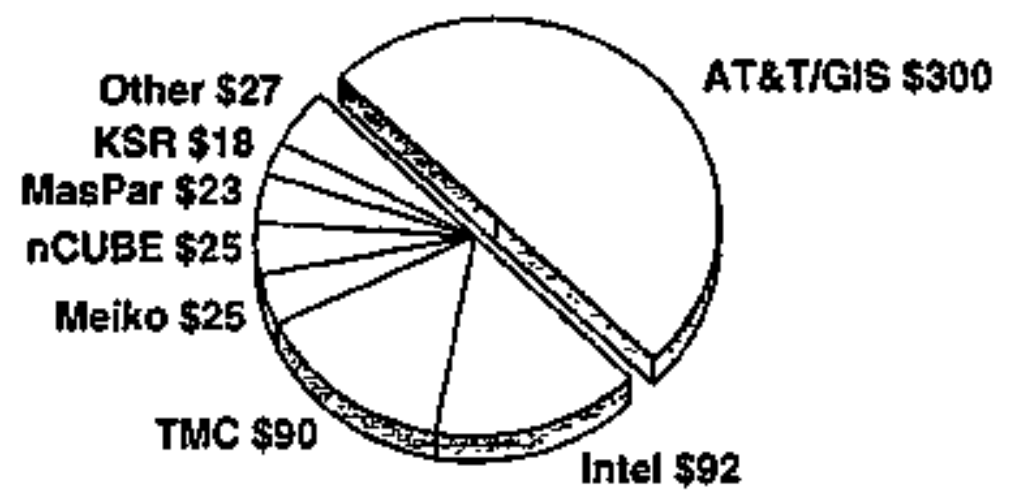




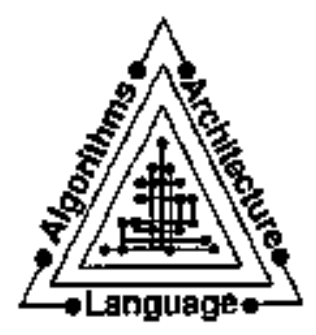

Supercomputing in the ross

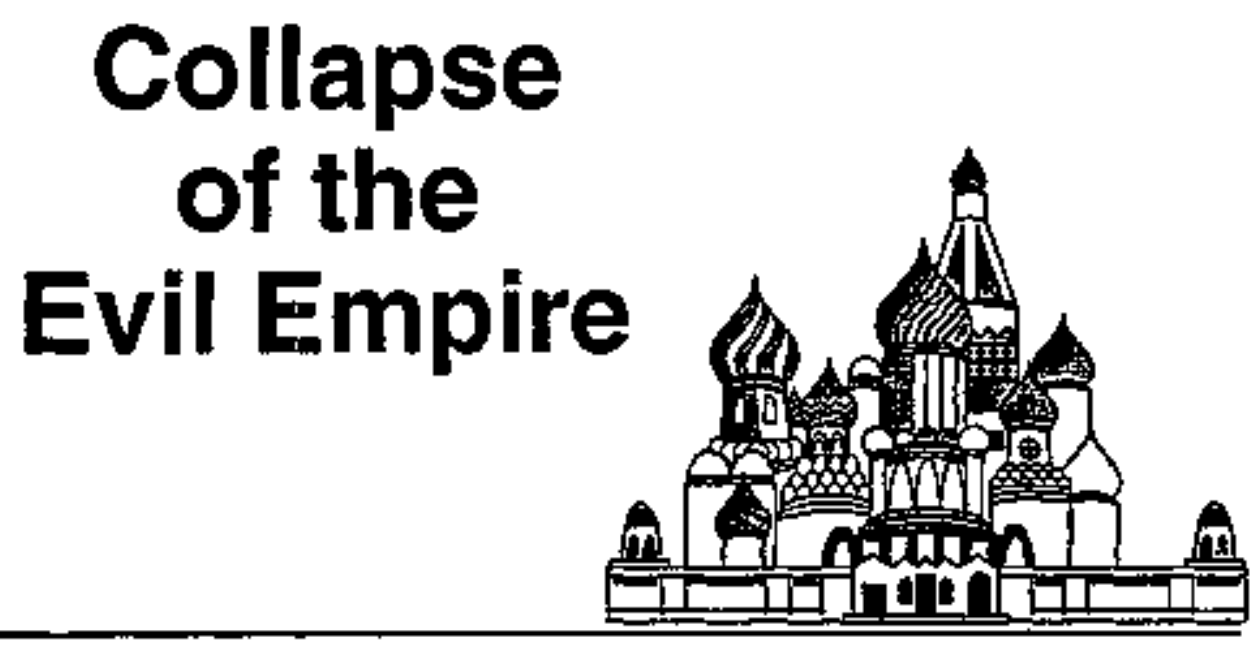

from

Nukes and Spooks
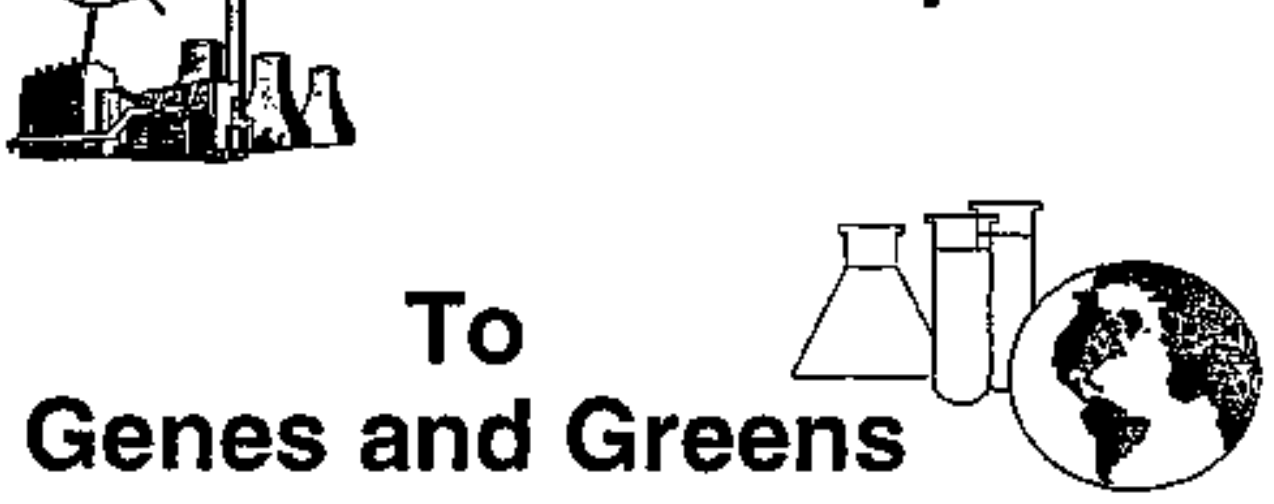


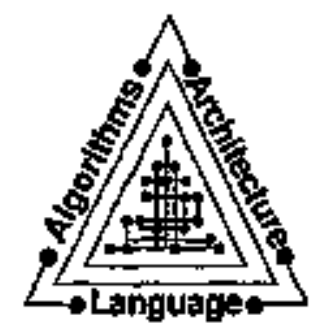

\section{Other People's Money}

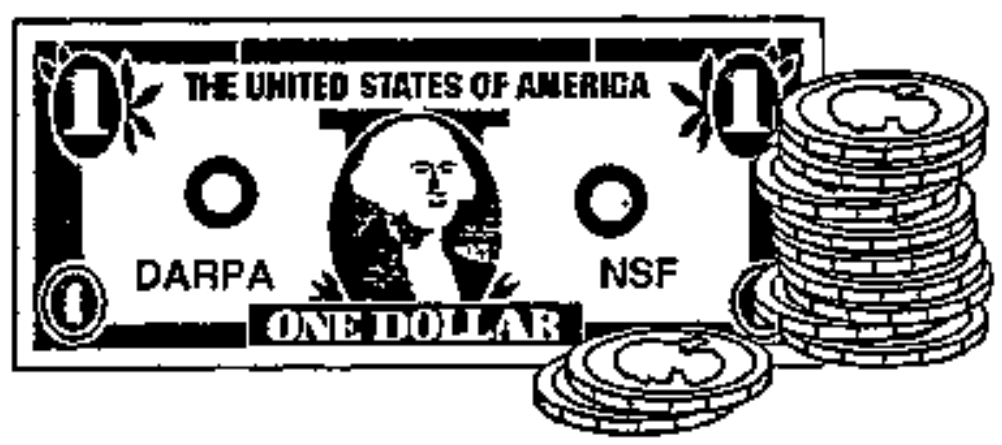

\section{MPP \\ Goes \\ Commercial}

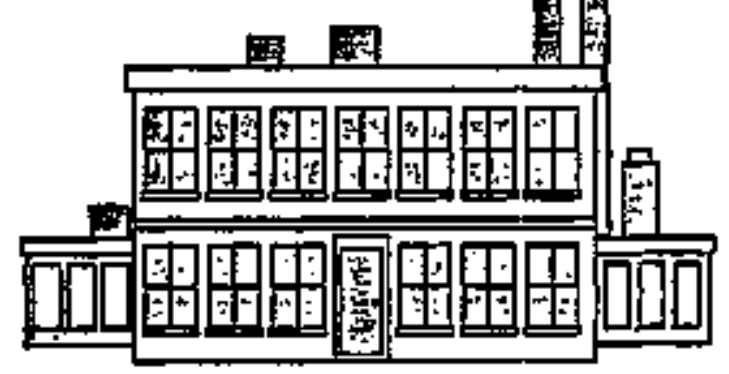




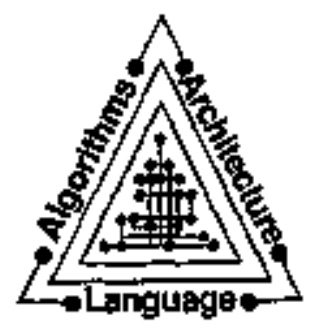

\section{The Corporate Database}

Woven into the Strategic Fabric of Business

C Database Mining as a Competitive Weapon

\section{"We are drowning in information but starved for knowledge."} John Naisbitt 


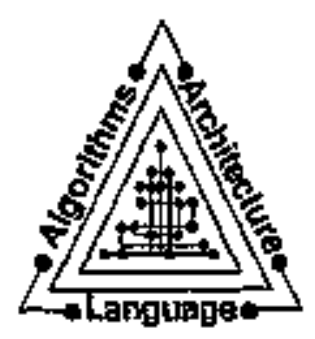

\section{The Opportunity:}

Forward-thinking is managers are deploying new MPP technologies to competitively leverage their most valuable asset.

\section{Why MPP?}

I Compelling Price/performance

- Tremendous Scalability

$\square$ Tolerable Entry Price

- Tackle Intractable Problemis 


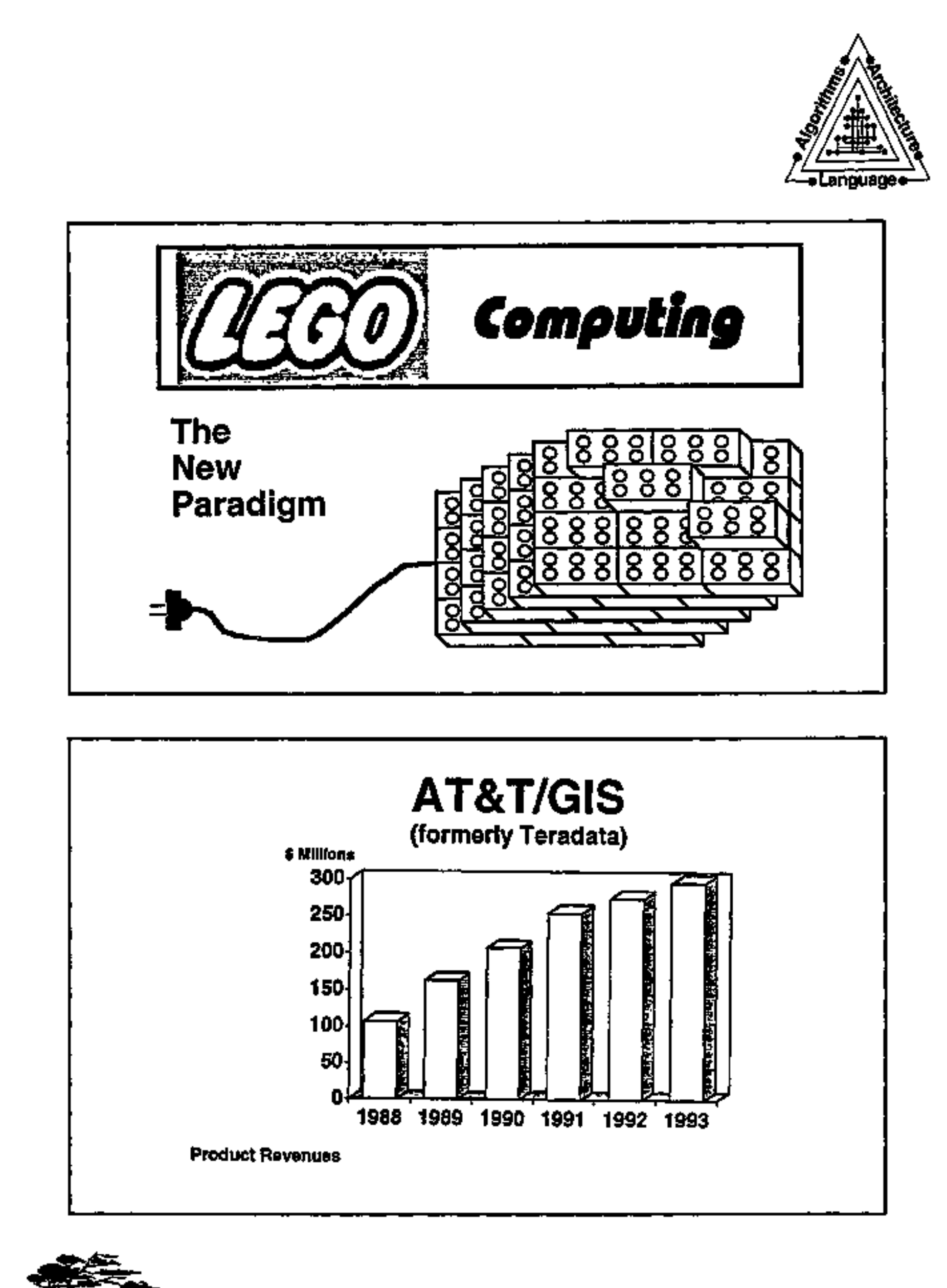




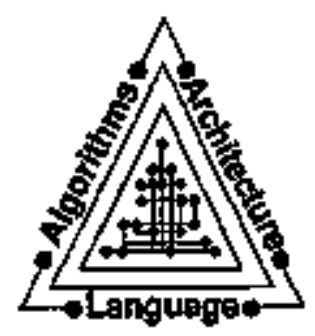

\section{MPP Market Leaders}

Scientific/Engineering/Technical $\$ 300$ Million

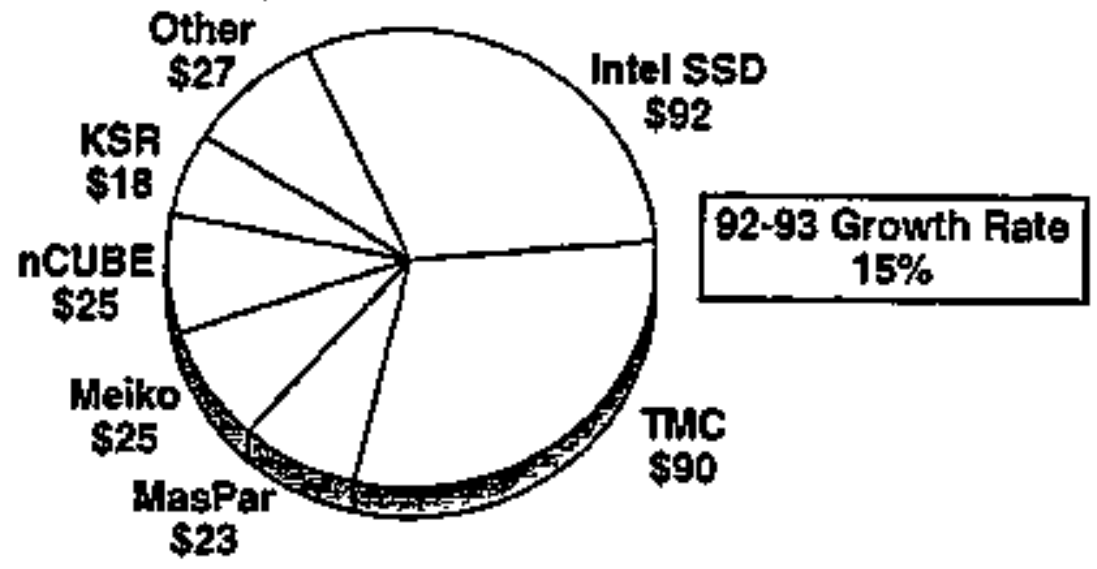

\section{Can Early Adopters Claim Success?}

Real customers are tackling real problems across the industrial spectrum:

Einancial Manufacturing

E Banking $\quad$ Retail

- Health Care $\square$ Transportation 


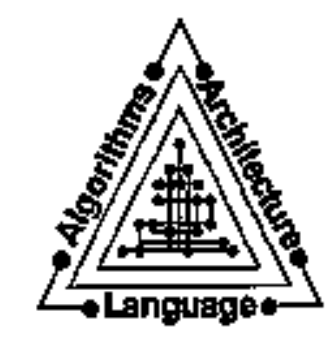

\section{AT\&T/GIS \\ (formerly Teradata)}

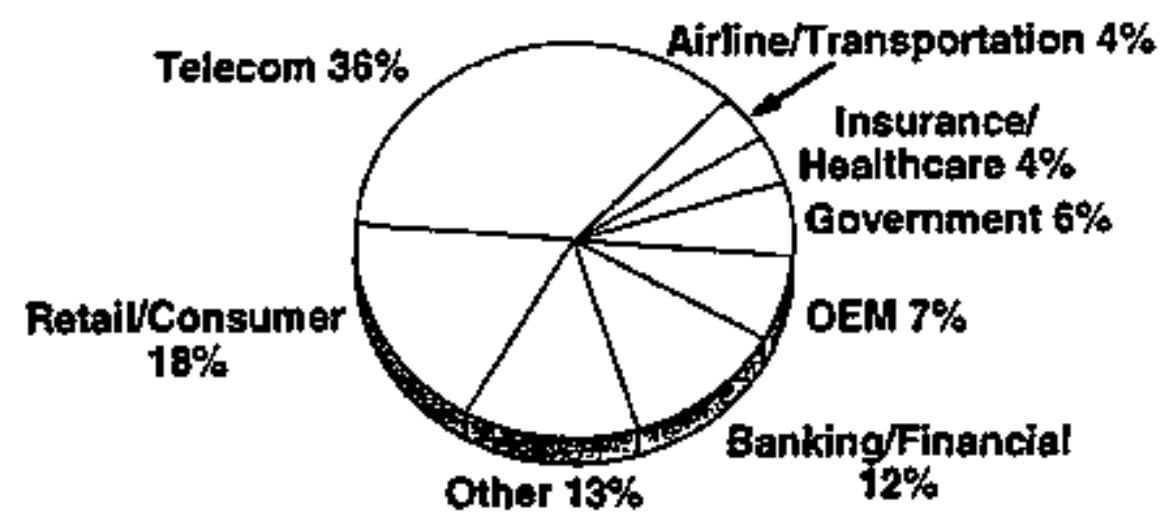

1991 Infalled Ease by Industry

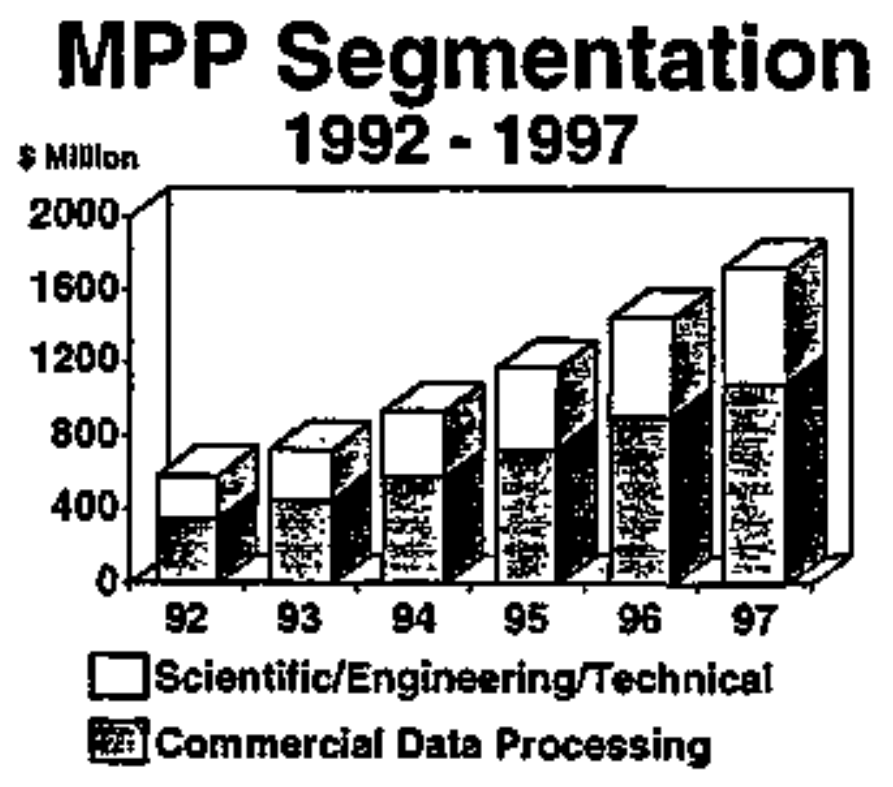



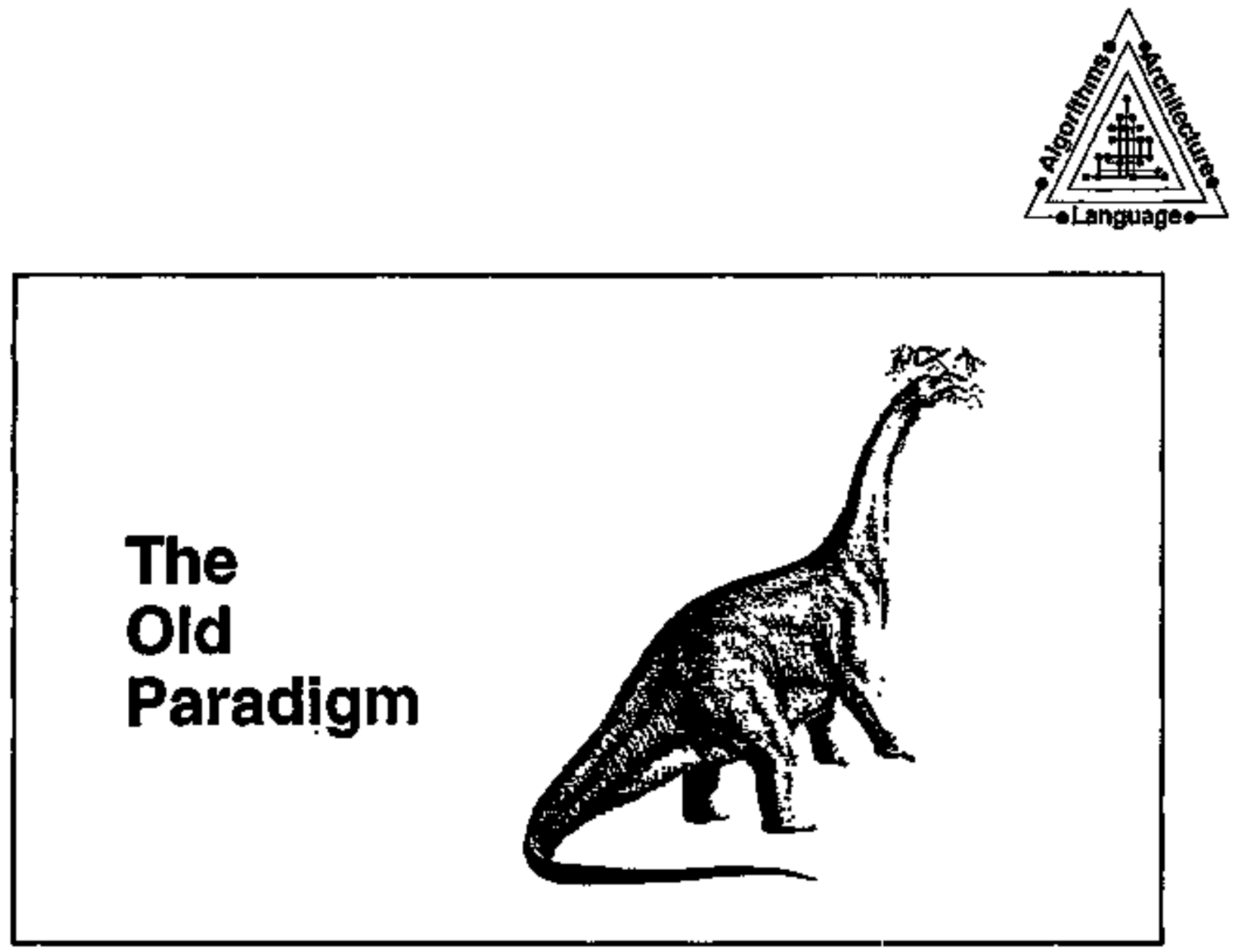

IBM 3090 PHOTO 


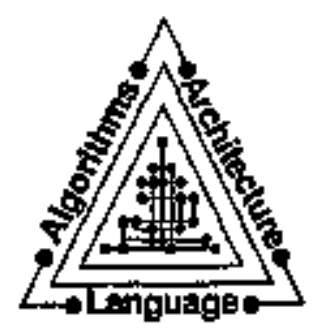

\section{A New Paradigm}

$\checkmark$ Killer Micros

$\checkmark$ Software is King

$\checkmark$ Open Architectures

$\checkmark$ Standards DomInate

$\checkmark$ Proliferating Networks
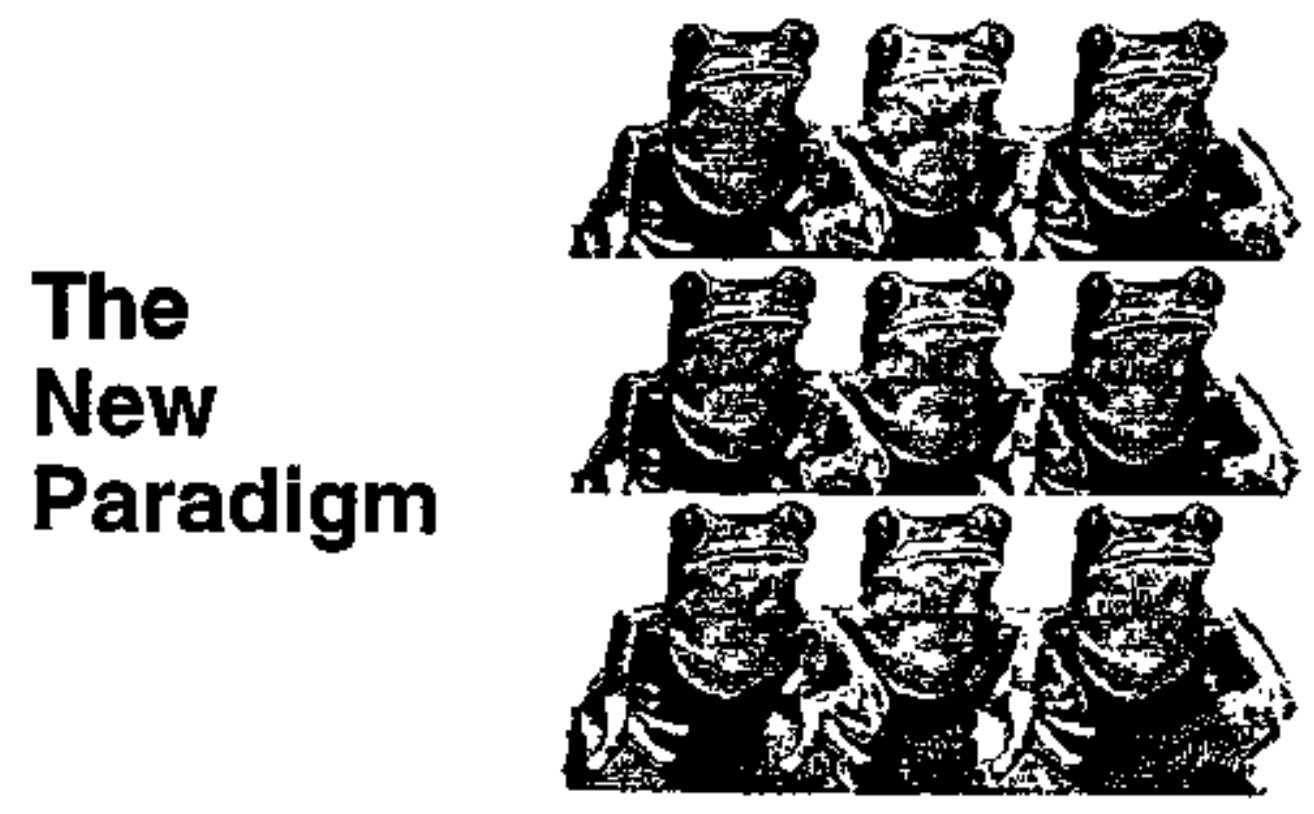


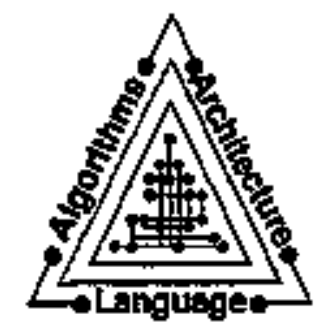

\section{Near-Term Outlook}

- MPP - Enabling Technology

- New Class of Applications

- One Piece of the Puzzle

- From Testbed to Production

- Transition Will Take Time

\section{Emerging Applications}

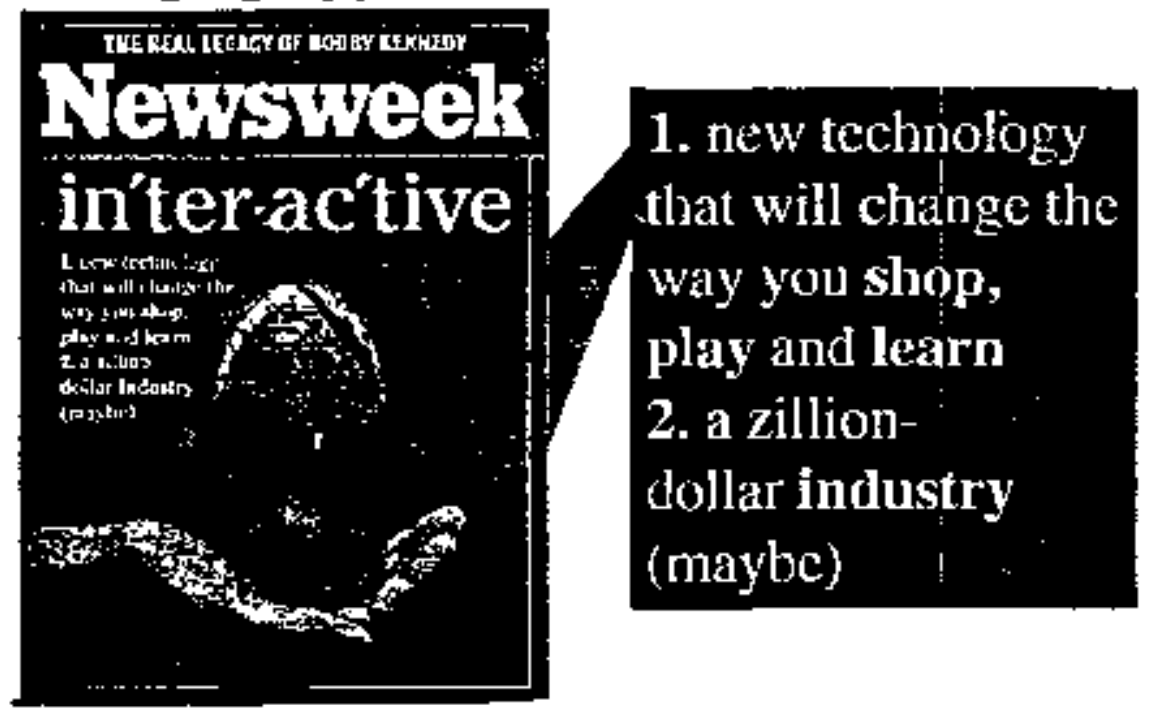




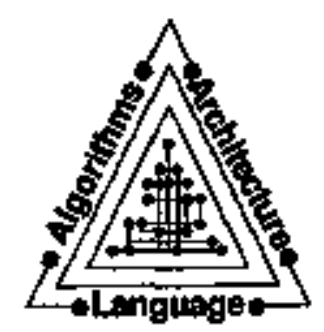

\section{Emerging Applications}

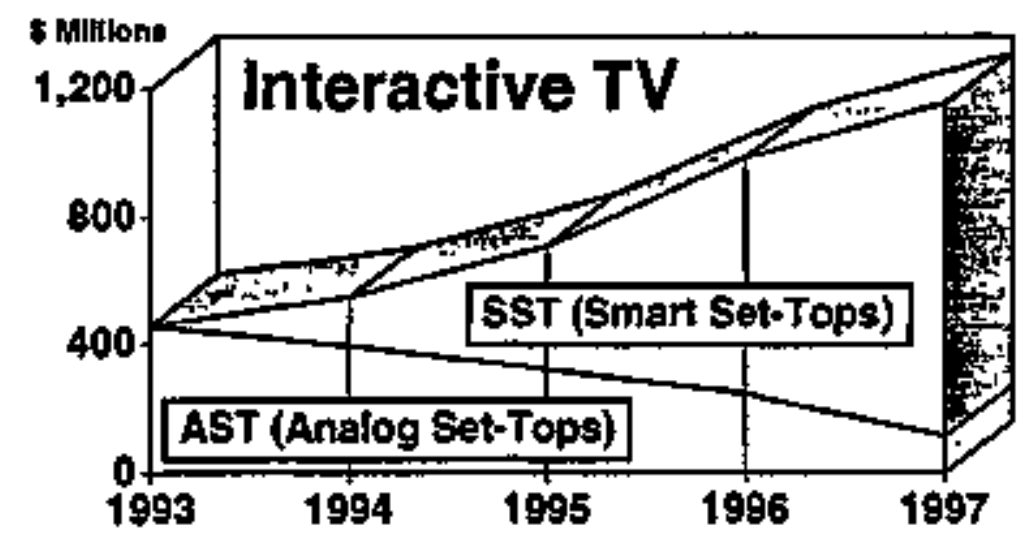

Anneral Sales

\section{Emerging Applications}

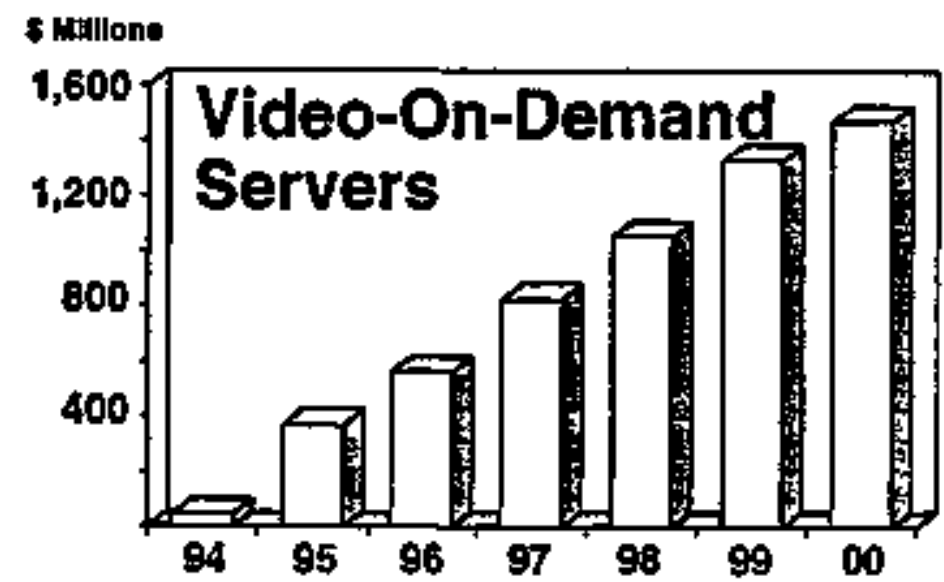

Anutul Sales fHlph-End sytuma 


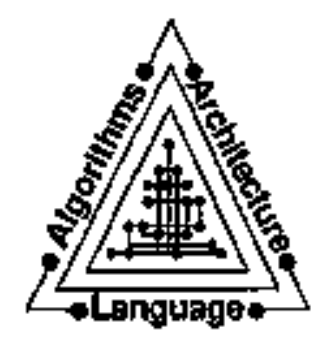

\section{Emerging Applications}

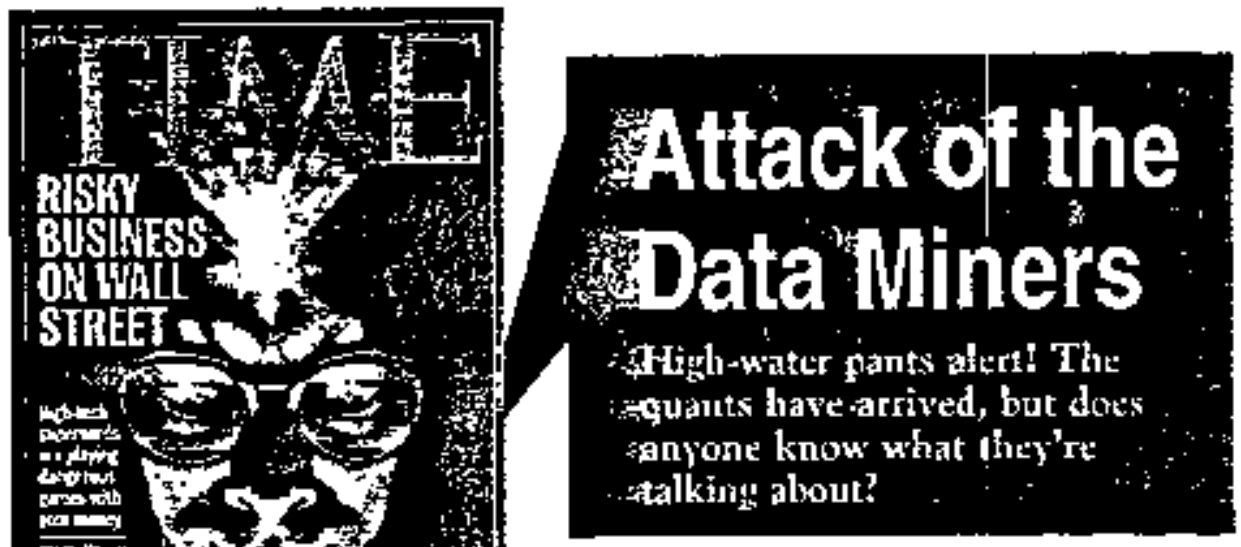

\section{"The greatest challenge of the computer industry is to learn how to build information bases, not databases."}

Peter F. Drucker 


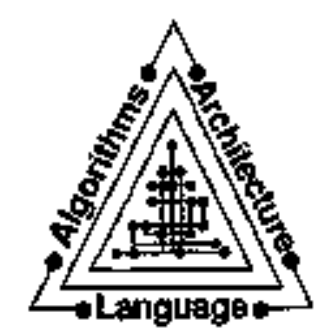

\section{Is MPP Industrial Strength?}

E Connectivity and Transparency are Key to Commercial Users

- Support Tools and Infrastructures Still Immature

Supercomputing in the $90 \mathrm{~s}$

Variations

on a

RISCy Theme
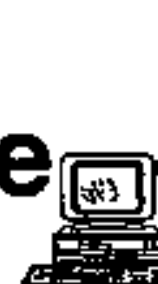

Farms, Clusters, Servers

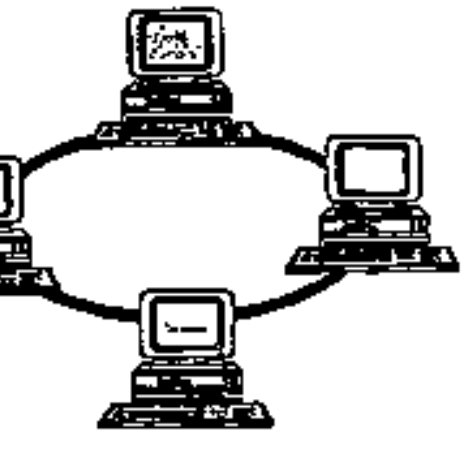




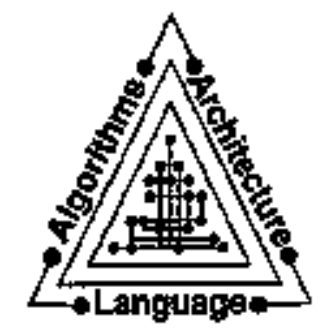

\section{Supercomputer Market}

Scientific/Engineering/technical

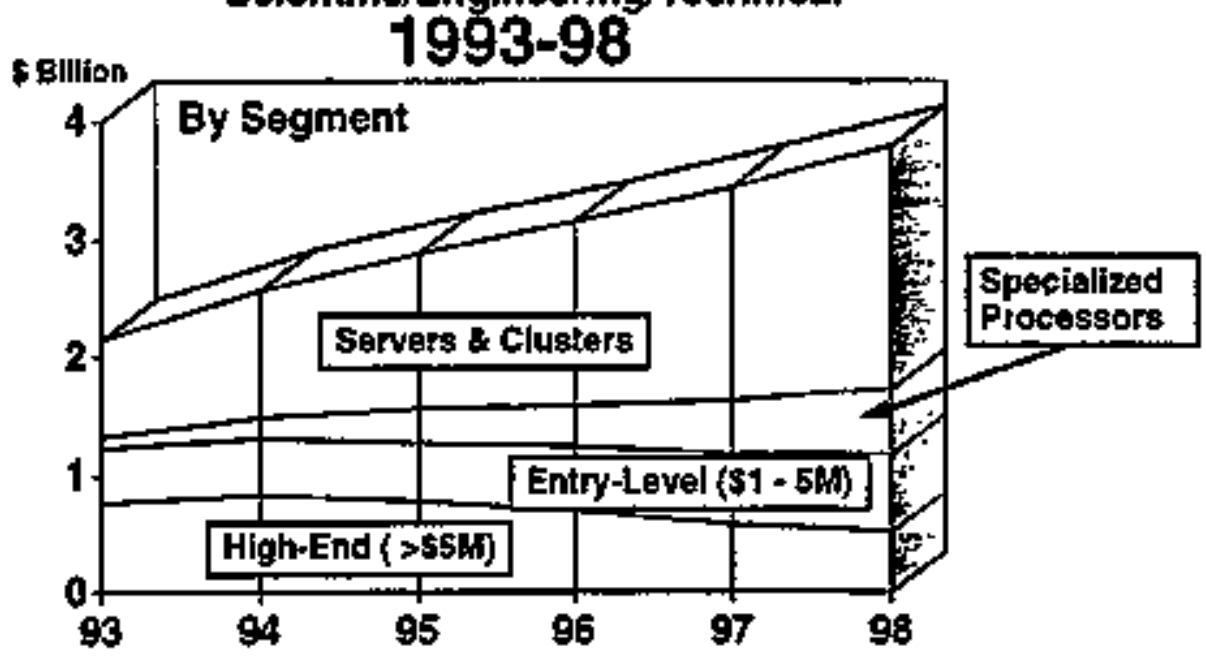

\section{Supercomputer Market}

Scientifio/Engineering/Technical

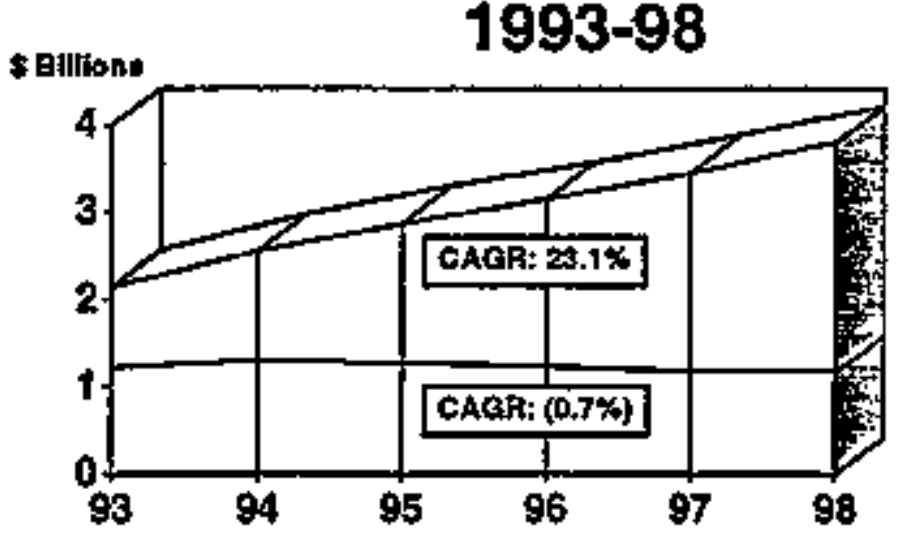

Departmental

Systems

Enterprise

Systems

Forecast By Markot Swgmint 


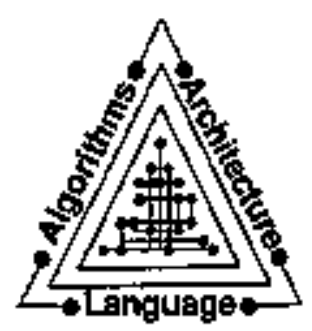

\section{Architectural Evolution}

Scientific/Engineering/Technical

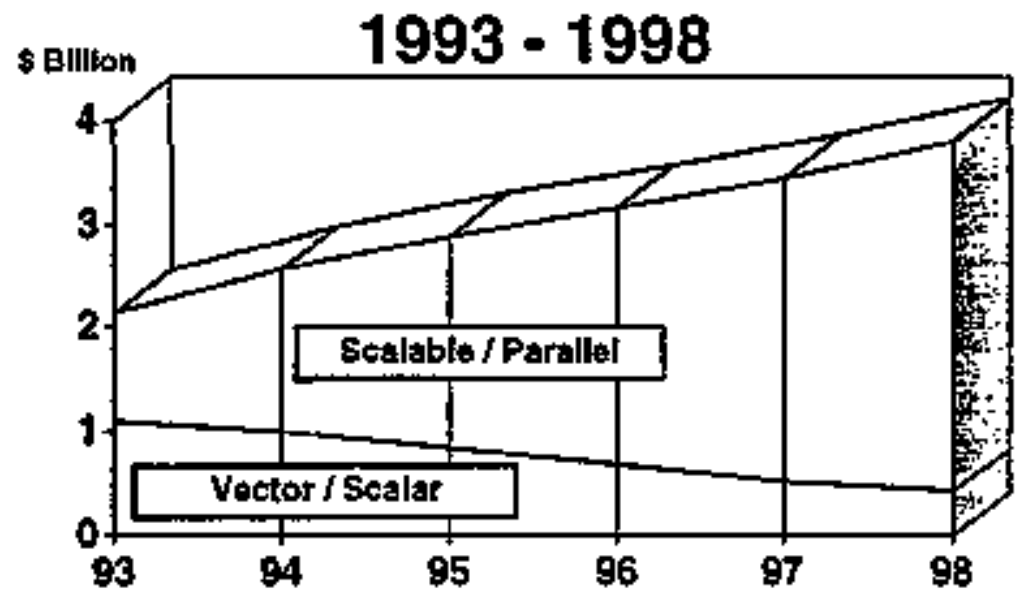

\section{Outlook for the '90s}

$\checkmark$ Moderating Growth

$\checkmark$ Continued Globalization

$\checkmark$ Decade of the Database

$\checkmark$ Complex Distributed Computing

$\checkmark$ Digitization of Everything 


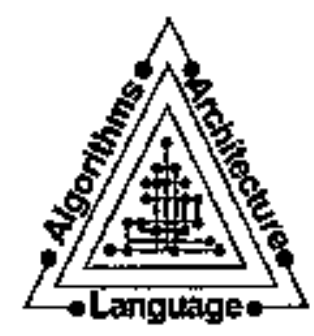

\section{Supercomputer Market Scientific/Engineering/Technical $\$ 2.57$ Billion}

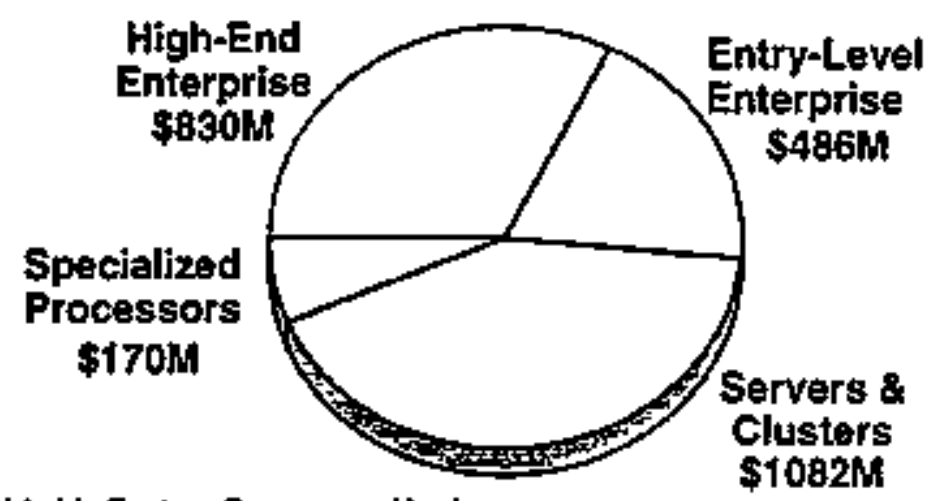

Total Wotldwide Follory favenuet - Hardwaze

\section{Supercomputer Market \\ Scientifie/Engineering/Technical}

$\$ 3.8$ Billion

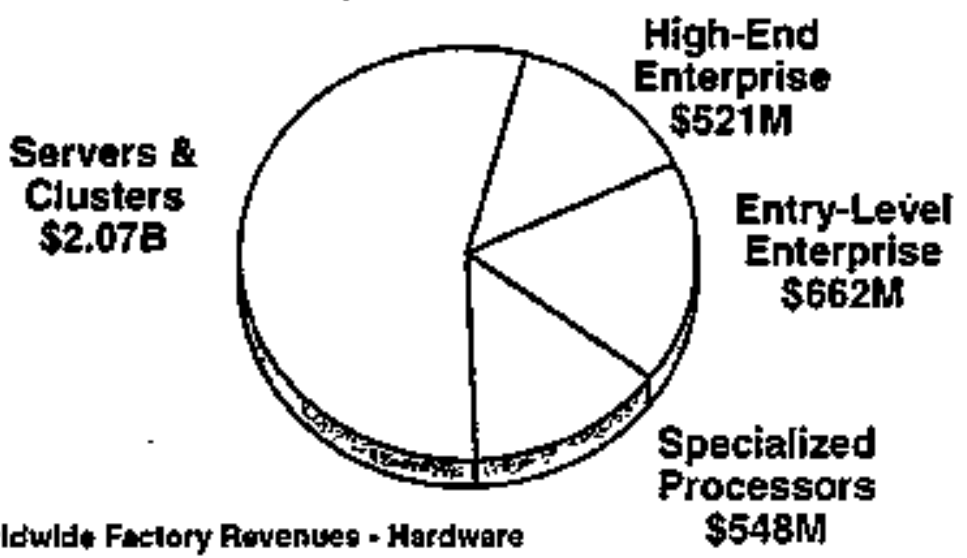

Total Worldwid Faclory Rovenues - Hardware 


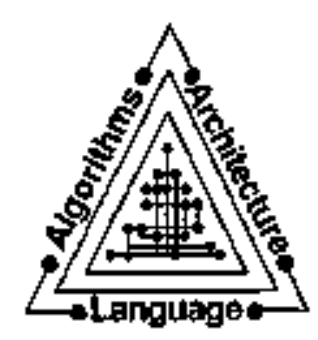

\section{Supercomputer Market}

Scientific/Engineering/Technical

1993-98

$(-7.3 \%)$

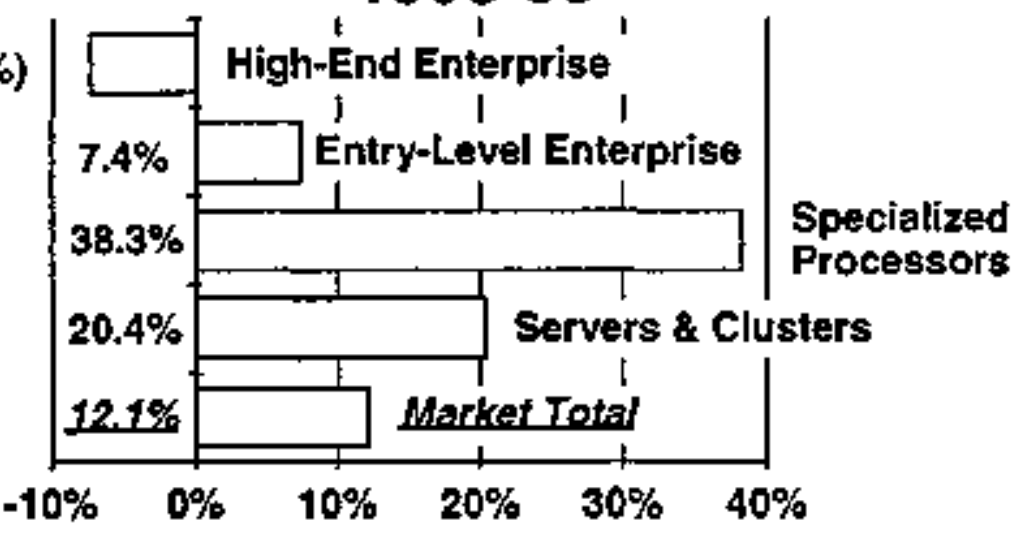

Segrient Growth

\section{Challenges}

$\checkmark$ Riding Out the Recession

$\checkmark$ Staying Lean and Mean

$\checkmark$ Picking the Right Horse

$\checkmark$ Shrinking Product Cycles

$\checkmark$ Product Differentiation 


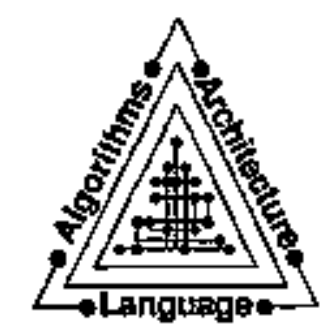

SGI LOGO

CRAY LOGO

IBM LOGO

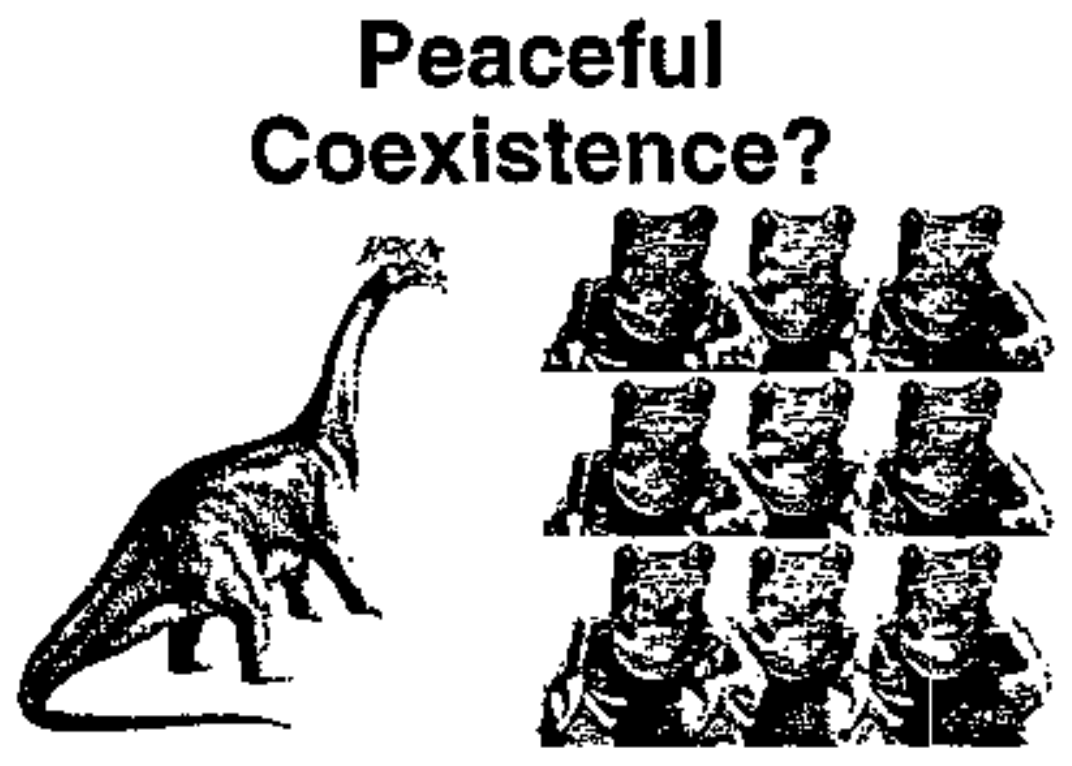




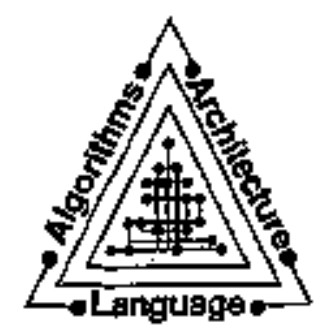

\section{Industry in Context}

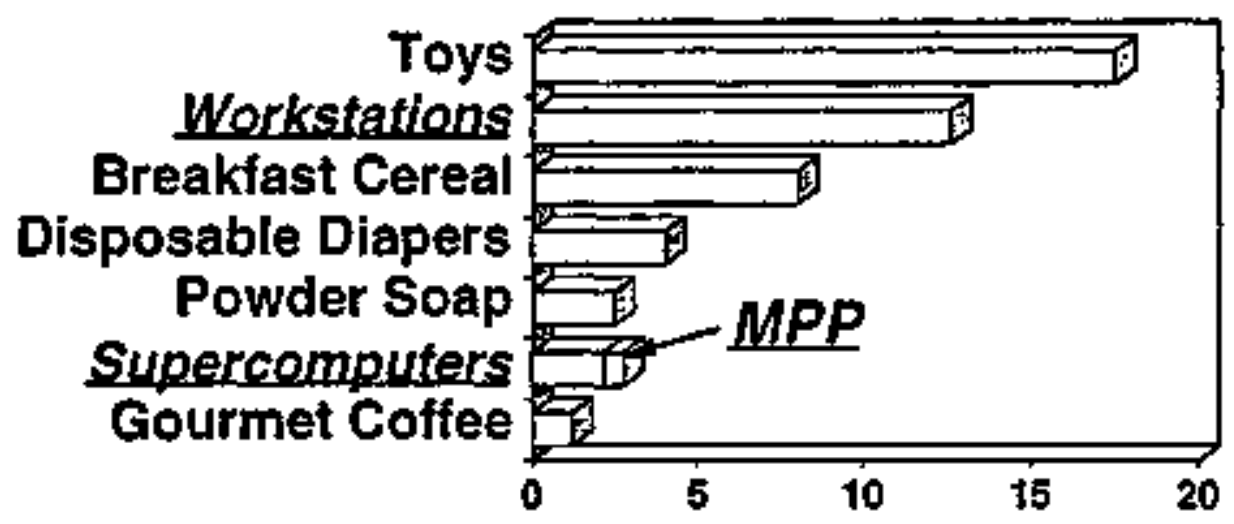

Annual Sales in Billion Dollars 


\section{IS ECONOMIC COMPETITIVENESS A MISSION?}

Hassan Bayem, LANL

\section{CHALLENGES FACING}

THE NATIONAL

LABORATORIES

NATIONAL LABORATORIES*

\begin{tabular}{|c|c|c|}
\hline & Staff & $\begin{array}{l}\text { Operating Budiget } \\
\text { (milfions) }\end{array}$ \\
\hline Idlaho & 8,424 & $\$ 858$ \\
\hline Lawrence Lhermore & 8,035 & $\$ 1,146$ \\
\hline Los Alamas & 7,550 & $\$ 1,024$ \\
\hline oakridge & 4,855 & $\$ 505$ \\
\hline Sandla & 8,600 & $\$ t, 400$ \\
\hline "FYredora & & \\
\hline
\end{tabular}




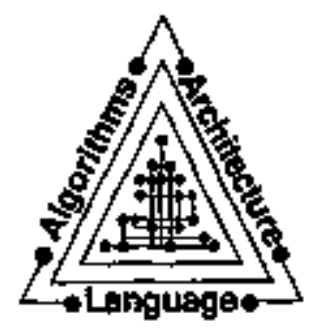

\section{LABS = SCIENCE \& TECHNOLOGY}

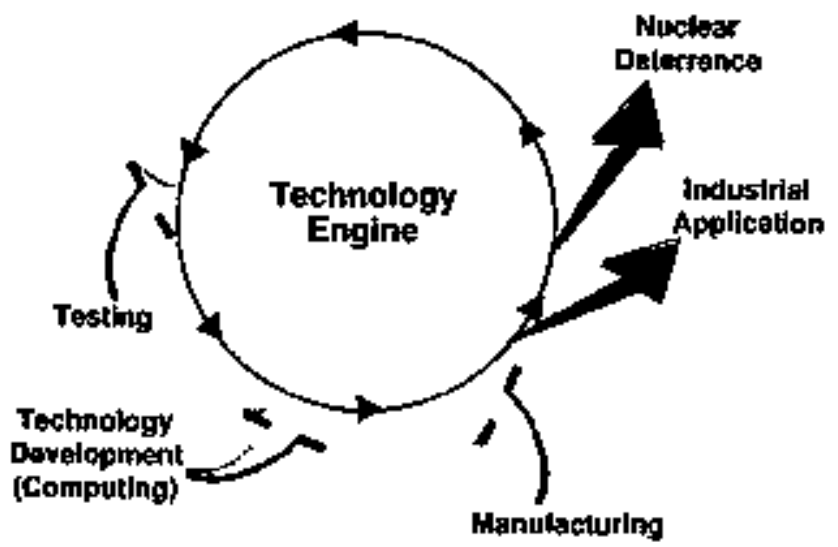

sin.

\section{POST-COLD WAR MISSIONS FOR LOS ALAMOS}

- Datensa needs

Reduce the auelear danger. \$lewardshlp lor nuclesr wespong and

kechnology. nonprolileralon, and manage the legecy of so yearts th

production. Technology for nonnuclear deferse and Imetligence.

-Cwillan nailonal needs

Governmonl driven: agency and industry calbobration

- Enargy

- Basic tomento

- Enviromtonint

- Edvealion

- kilrasinucluse

- Space

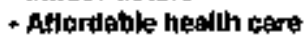

- Commercial tochrologios

Industry dituen

- Cost-shared, maket-drhan reserrch ond development

- Uzer tocilliles

- Technology essibtanos

- Enirepreneurifal starl-ups

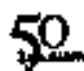



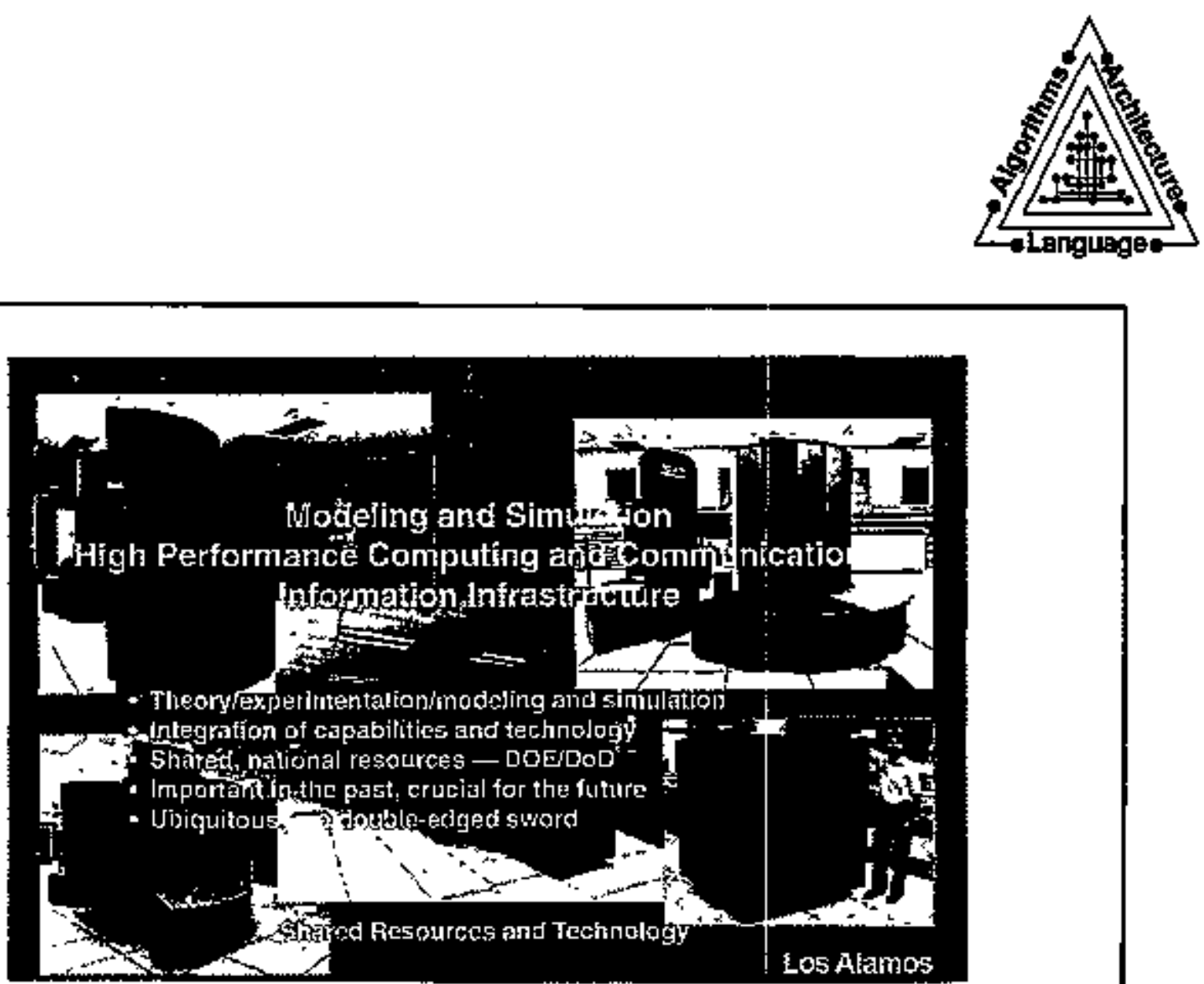

National Security

- Heducing the nuclear daluger

- Stockplin stewardstrip

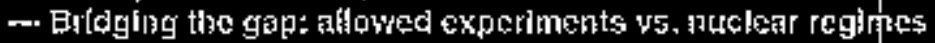

- Simulation of complex syatems with human declsion makers

- Imeccasing importance of modilling and simulation

- Increasing costs, both hardware and pecple. Therelore, we must have shared responsib]lity for this critical technolosy.

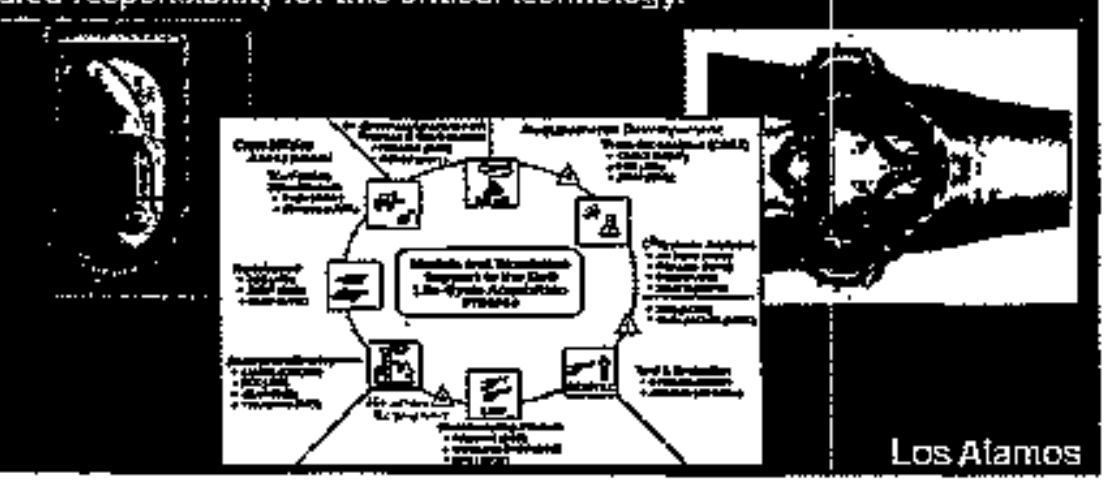




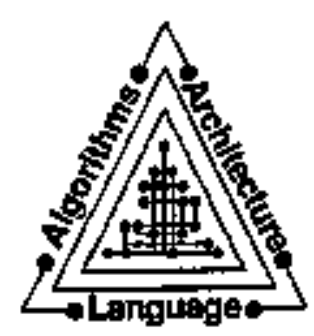

\section{National Challenges}

- Socintal impact an achicucd goal - we necd to show the way

- Crulical component in reitusenting the way we do things

- Agite simulation

- National Information Infrastructure
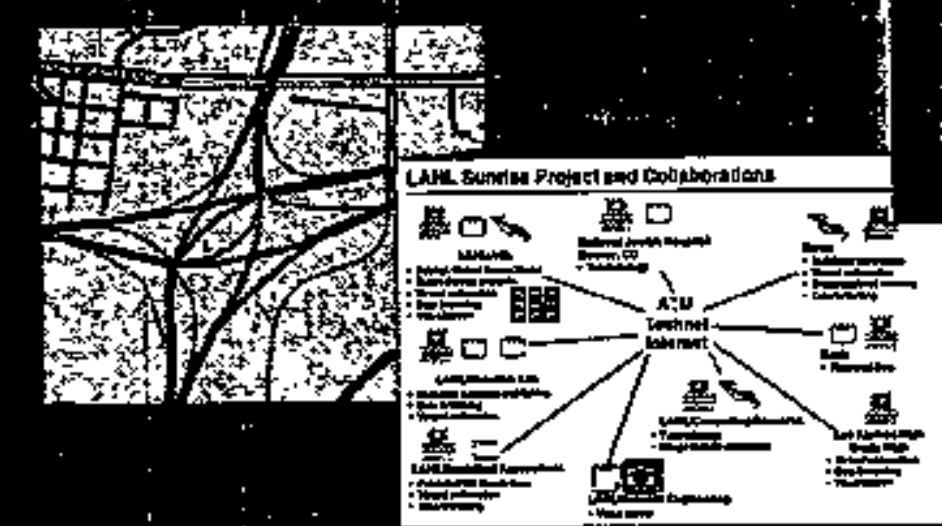

\section{Scionce}

- Capakjitity is a difeol result of national security reguirements

- Technology is on the threshold of rematkabtr scicnlific achievements

- Computatiorial Sclence is an emerglng discfillne

- Enables indústrial coilaboralios

- Acsource stianing a nust

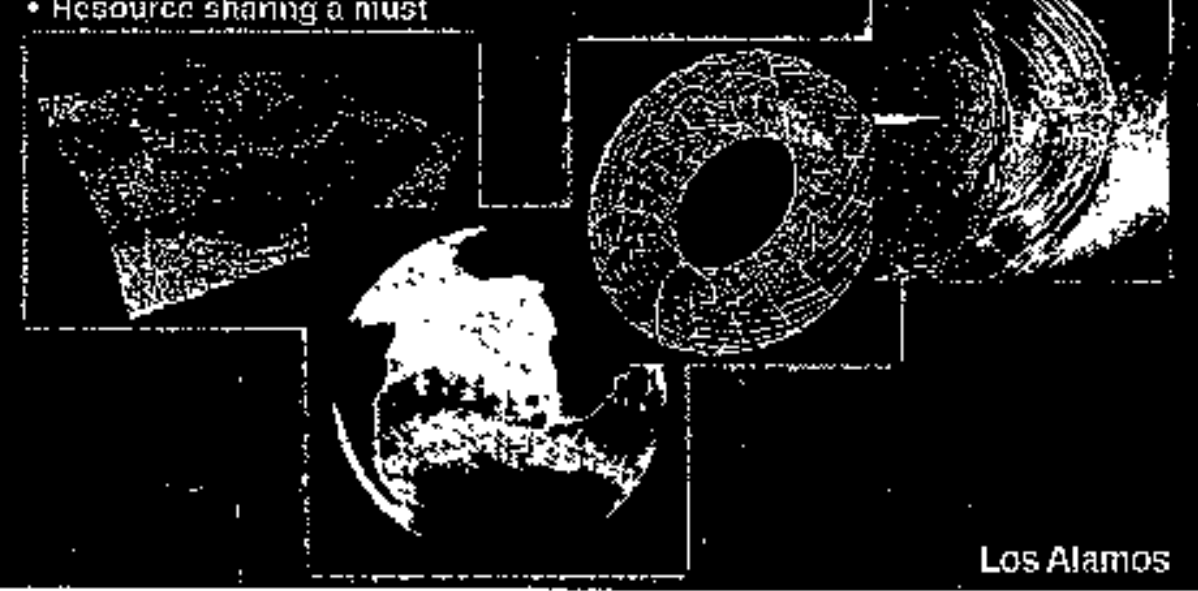



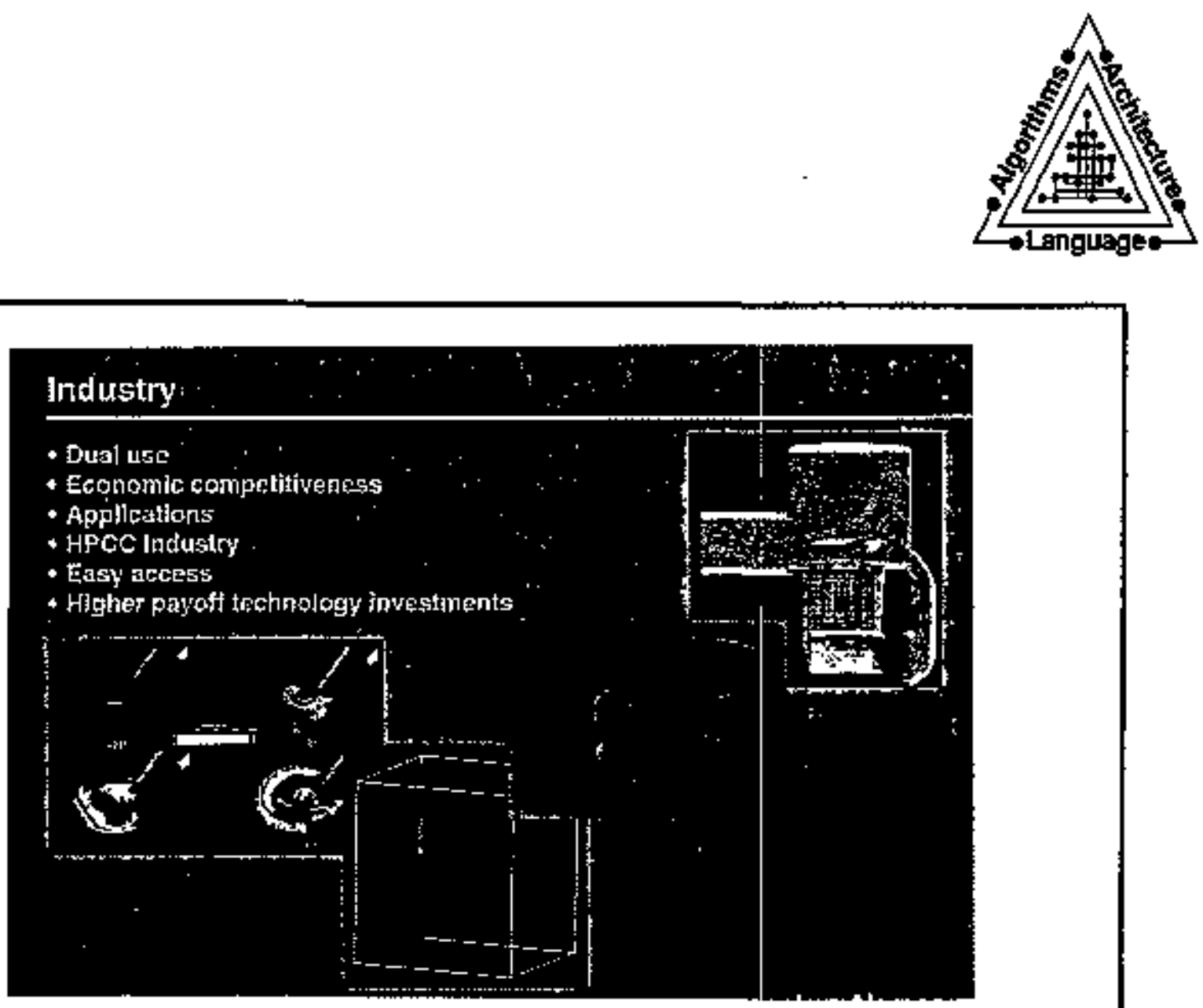

\section{UNDERLYING ISSUES}

- Defense conversion

- National economic competitiveness

- Nuclear compelence

- Compotition within industries

- Industrial policy

- Cost sharing

- Staying power of the Labs

- Identlfication and sefection of areas of cooperation 


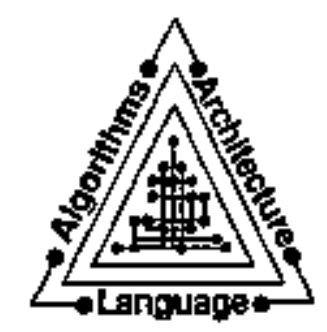

\section{LOS ALAMOS INDUSTRIAL COLLABORATIONS}

+ 85 CAADAS

- Apponimataly \$200m

-1/4 small businesses

- 45 Licensess

- 3/4 small buginesses

- 39 Componles storted using LANL dovtoptd lochnologies

Exomples: Heat pipes:

Laser - based cell sorting

Side - coupled cavlly acceleralor

- \$1日 indusirial revenues

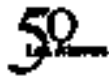

\section{IS ECONOMIC COMPETITIVENESS}

\section{A MISSION FOR NATIONAL LABS}

Yes

- Leverage tax poybrs' investment

- Maintain nuclear deterrence

- Sohve large, complex, interctisciplinary problems

- Stralegic research

Is.

- A de facto industrial policy

- Business knows best; just give them the money lhat wosld go to the labs

- Labreiou response time loo long

- Japen modal

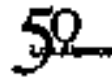




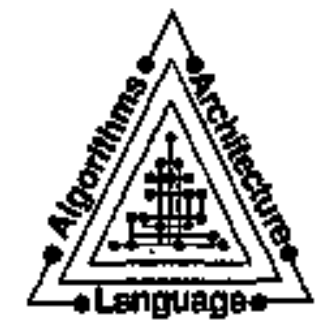

\section{LABS STAYING POWER}

- Changing geopolitical priorities

- Changing national priorlties

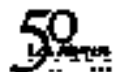

\section{NUCLEAR COMPETENCE}

- Credible detertence

- Capable people

- Dual use science and technology 


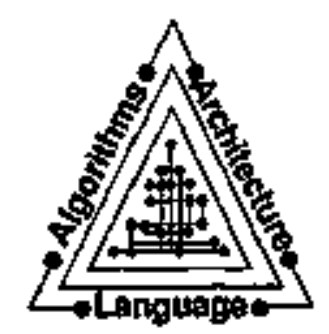

\section{COMPETITION WITHIN INDUSTRIES}

- Precompetitive technologles

- Who do the labs work with

- How are partmers chosen

- Constructive action may block other opportunitles

- How coes industry find out what labs have

- Commodity is knowledge - make more accessible

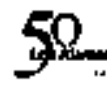

\section{NATIONAL ECONOMIC COMPETITIVENESS}

Law - Labs can't compete with industry

- Polliles of industrial policy

- Malntaining indurstrial Competence

- Lab Invastment Is irrelevand

- Inqoet is through R\&D

- Univergity $\$$ indugtrial labs 8 ag notional Lobs as competitors 800 tb. gorillas

- CAfD. Lob mission sinte 1917 - beneftls mid ske compenles; technology developmentideploymen!

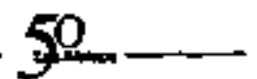




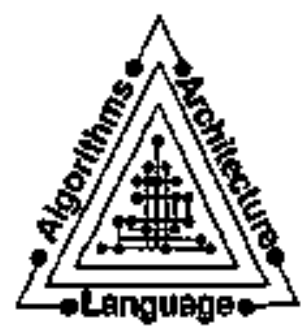

\section{DEFENSE CONVERSION}

- Lack of understanding of industrial needs

- High cost

- Mismatch in timescale industrylabs

- - bureaucracy Impediments

- proper scale of probtems

- - return on investment

Fight with plow shares \& plow with swords

\section{0}

$4 \ln 40$

We select our programs on the basis of our core technical competencies (what we do well) and our approsich to problem solving (how we do things)

- Cont Teevalcal Compalentes

- Futctear weepans selence and technology

- Thoory modeling and Wgh parformente tompualing

- Compiar experimentrotion and mensuramem

- Nuclear and atvetaced mitierial

- Earth ond emplronmental sysiems

- Gloselences ant bloterehnolíy

- Analysis and essessnatekt

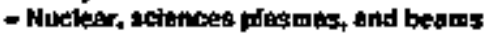

- Los Alomps solves problenas that typicolly:

- Are large In soals of Hma, apece, size, of tomplexthy

- Fipplro at atrong acdente beso

- Requira engintering hamwork, and speclal kaciloties

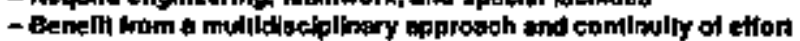

- Benelis the pubito 


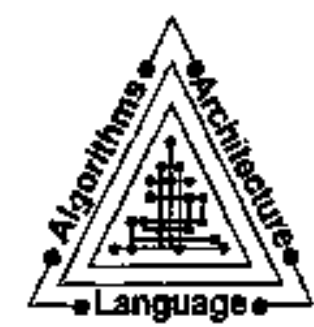

\section{MISSION}

The Los Alamos National Laboratory is dedicated to developting world-class science and technology and applying them to the nation's security and well-being. The Laboratory will continue its special role is defense, particularly in nuclear weapons technology, and will increasingly clvtltan problems.

50 


\section{CCC: \\ CRIMINALS CAUGHT BY COMPUTING}

Tom Kraay, Booz, Allen and Hamliton, lnc.

\section{Quantifiable Damage to the Public On a Yearly Basis}

- Drugs

- Telecommunications Fraud

- Welfare Fraud

- Social Security Fraud

- Food Stamp Fraud

- Worldwide Credit Card Fraud

- Heatthcare Fraud

- Property and Casualty Insurance Fraud

- Loan Fraud

- Vandalism
$\$ 110$ Billion

$\$ 4$ Billion

$\$ 15$ Billion

$\$ 10$ Billion

$\$ 10$ Billion

$\$ 40$ Billion

$\$ 98$ Billion

$\$ 17$ Bitlion

\$t5 Billion

\$6 Btllion

More than 300 afllion

\section{Motivation}

- Over 1.B Million Violent Crimes Ocar Each Year Irchuding;

- Murders

- Robberies

- Kidnappings - Assaults

- Carjadoing

- Forible Rapes - Product Tampering

- Almost 16 Mfilion Property Crima Each Year Including.

- Larceny

- Theft

$\rightarrow$ Barglary

- Motar Vehide Theft

$$
\text { - Arson . }
$$

- Proliteration of nilicit Organizations lndudes

- Motorcyate Gings - Various "Posses"

- Rellgious Cults - Foreign Controlled Gangs

- Streat Gangs $\quad$ - Terrortst Organizations

- Fraud Costs to U.S. Citizens Hove Becone Unbeanabie

- Diffloult to detect

- Institultional, Colhusive, and Organizational Fruted is Causing the Most Danvige 


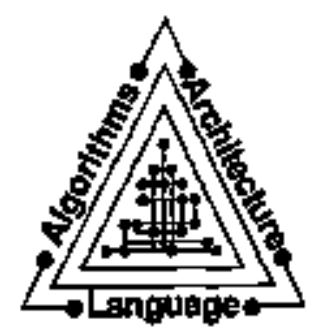

\section{Unquantifiable Damage to the Public}

- Death

- Disability

- Sorrow

- Grief

- Fear of Venturinis Out

- Fruskration

- Embarassment

- Quatily of Life

- International Perception of U.S. Society

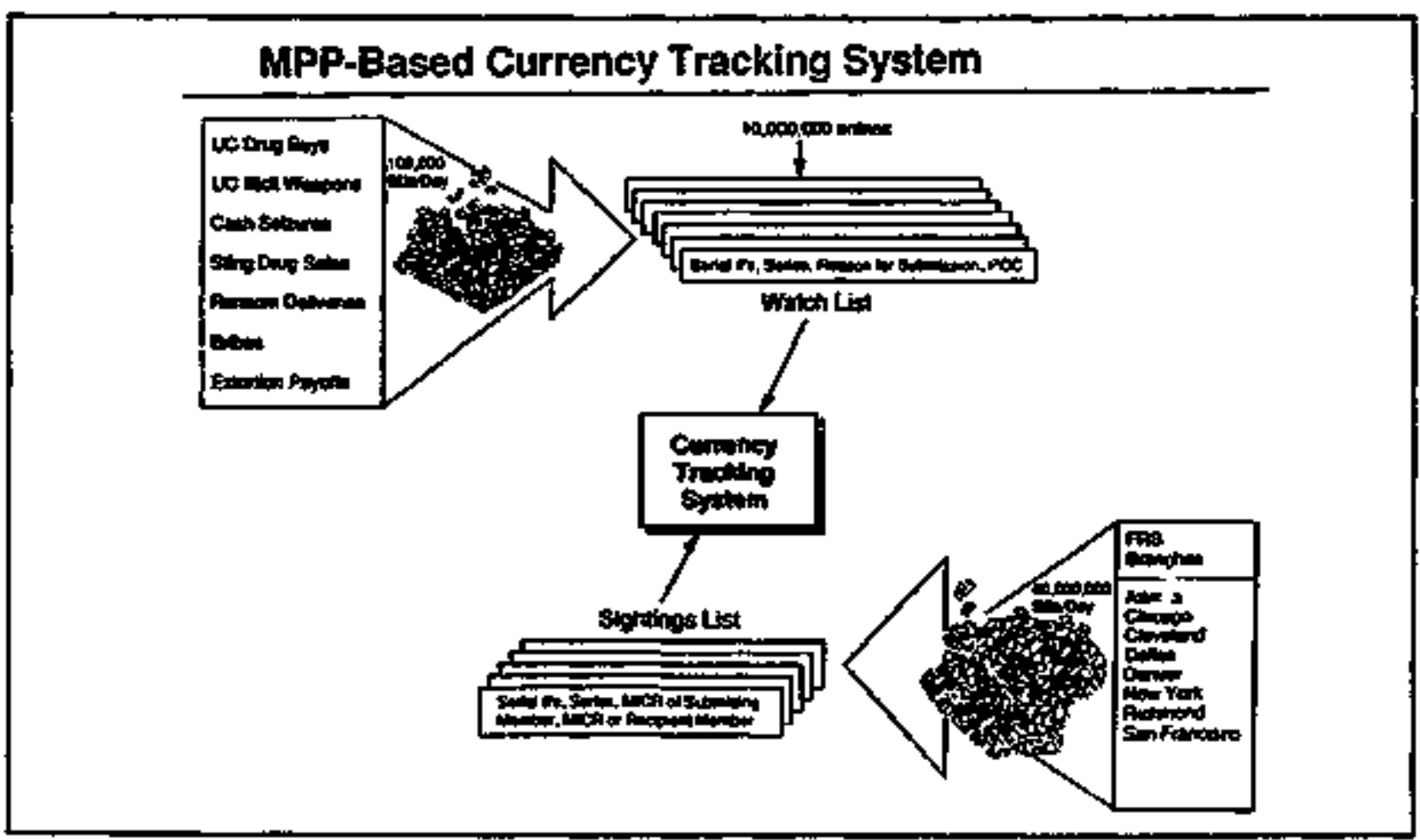




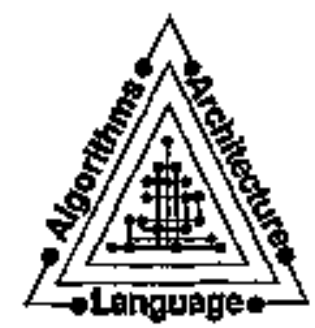

\section{Algebralcally Speaking ...}

$$
\begin{aligned}
& \sum_{i=0}^{n-1} c_{i}^{2}=1 \\
& \sum_{i=0}^{\frac{n}{2}-1} c_{2 i}-\sum_{i=0}^{\frac{n}{2}-1} c_{2 i+1}=0 \\
& \sum_{i=0}^{n-1-2 j} c_{i} c_{i+2 j}=0 \text { for } j=1,2, \ldots, \frac{n}{2}-1
\end{aligned}
$$

Cumsy System to Solve Because There Exist only $\frac{1}{2}+1$ equations in $n$ Unknowns

\section{To Simplify a Solution ...}

Introduce Additional Equations:

$$
\begin{aligned}
& 0 \cdot C_{n-1}-1 \cdot C_{n-2}+2 C_{n-3}-\ldots-(n-1) C_{0}=0 \\
& 0^{2} \cdot C_{n-1}-1^{2} \cdot C_{n-2}+2^{2} \cdot C_{n-3}-\ldots-(n-1)^{2} C_{0}=0 \\
& \vdots \\
& 0^{\frac{n}{2}-1} \cdot C_{n-1}-1^{\frac{n}{2}-1} \cdot C_{n-2}+2^{\frac{n}{2}-1} \cdot C_{n-3}-\ldots-(n-1)^{\frac{n}{2}-1} \cdot C_{0}=0
\end{aligned}
$$




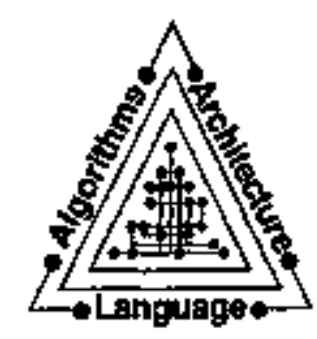

\section{The Four Coefficient Transformation Matrix}

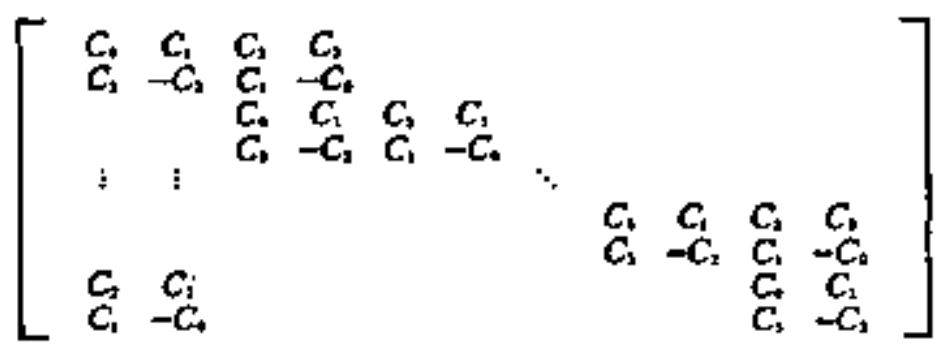

Choose the Ci's So That the Transpose of the Matrlx is Its inverse:

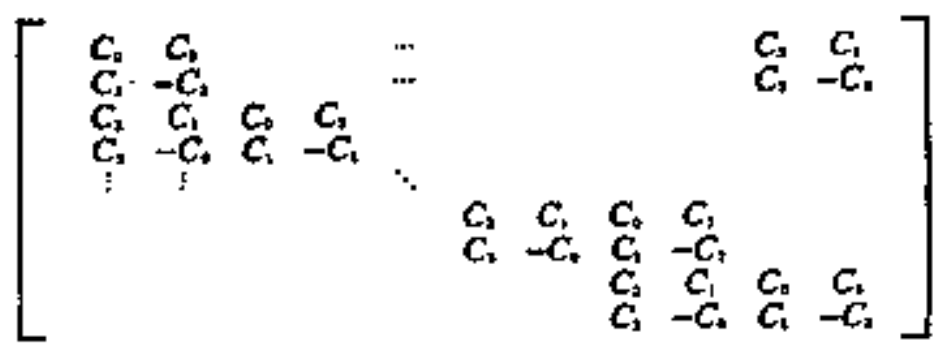

\section{Solutions to This System Lead to the Famous Daubechies Systems}

DAUB2: $C_{0}=C_{1}=\sqrt{\frac{1}{2}}$

DAUE4: $C_{0}=(1+\sqrt{3}) / 4 \sqrt{2} \quad C_{1}=(3+\sqrt{3}) / 4 \sqrt{2}$

$C_{2}=(3-\sqrt{3}) / 4 \sqrt{2} \quad C_{3}=(1-\sqrt{3}) / 4 \sqrt{2}$

DAUB6: $C_{0}=(1+\sqrt{10}+\sqrt{5+2 \sqrt{10}}) / 16 \sqrt{2} \quad C_{1}=(5+\sqrt{10}+3 \sqrt{5+2 \sqrt{10}}) / 16 \sqrt{2}$

$C_{2}=(10-2 \sqrt{10}+2 \sqrt{5+2 \sqrt{10}}) / 16 \sqrt{2} \quad C_{3}=(10-2 \sqrt{10}-2 \sqrt{5+2 \sqrt{10}}) / 16 \sqrt{2}$

$C_{1}=(5+\sqrt{10}-3 \sqrt{5+2 \sqrt{10}}) / 36 \sqrt{2} \quad C_{5}=(1+\sqrt{10})-\sqrt{5+2 \sqrt{10}} / 16 \sqrt{2}$ $\vdots$ 

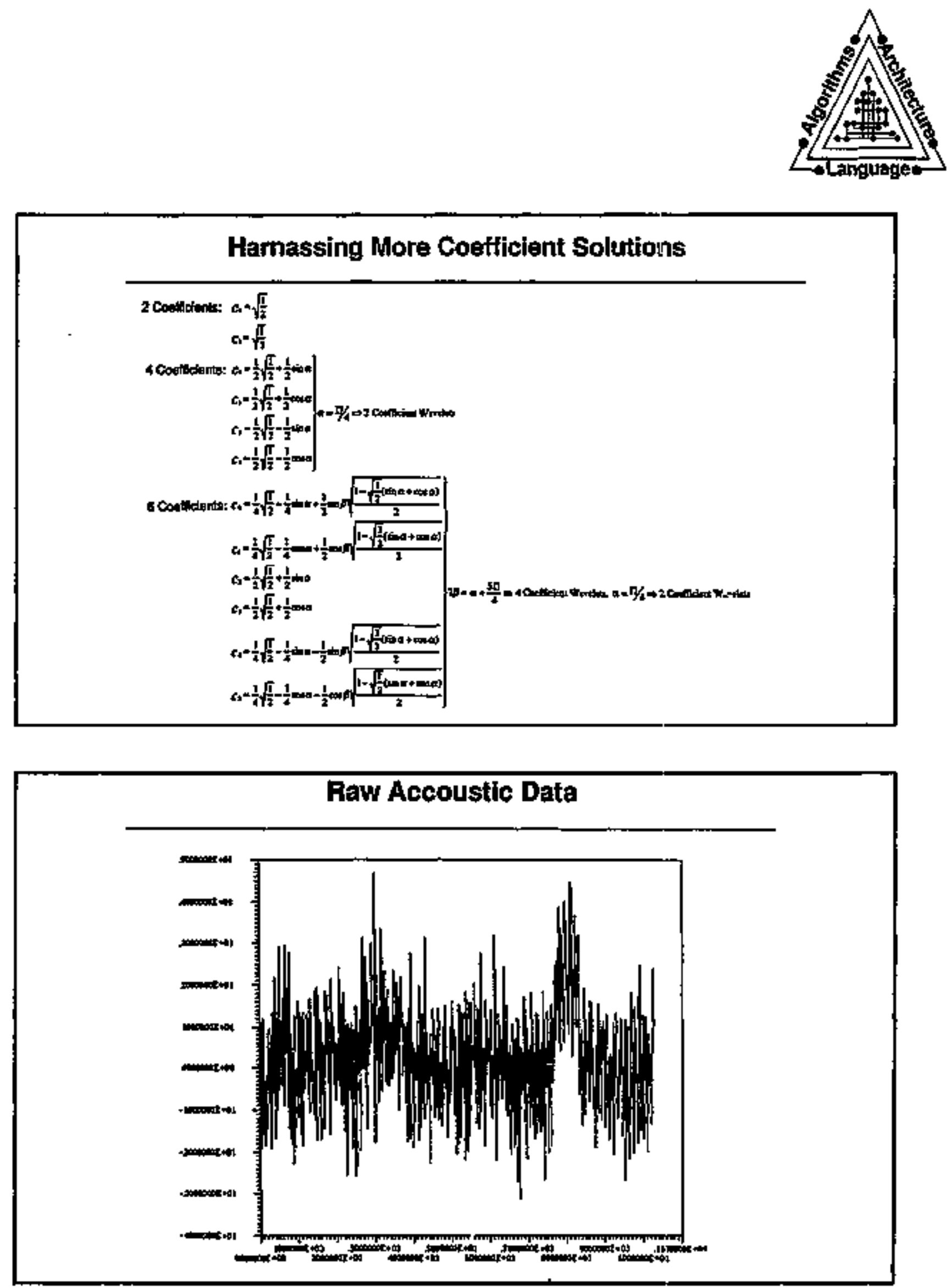

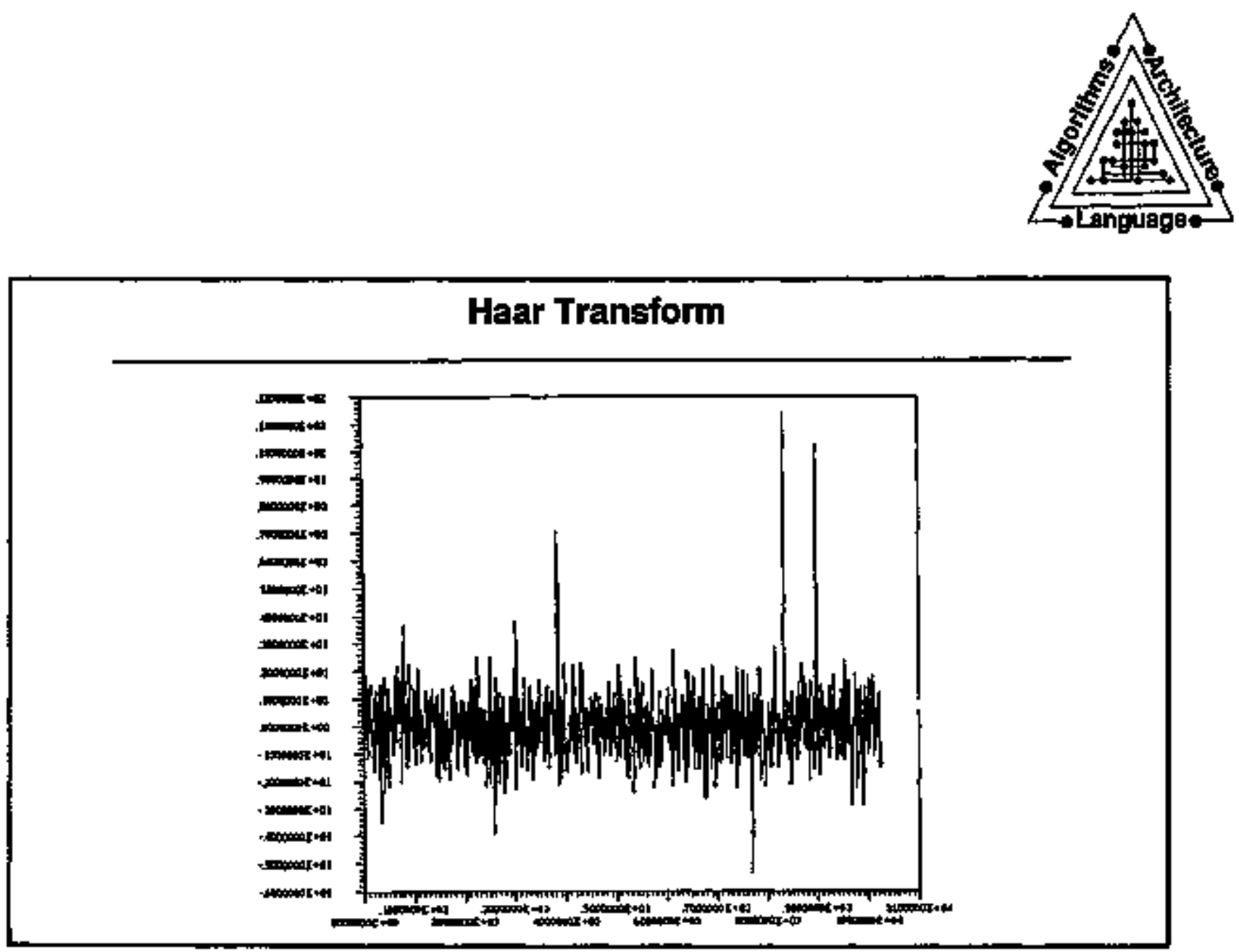

Filtered Haar Transform

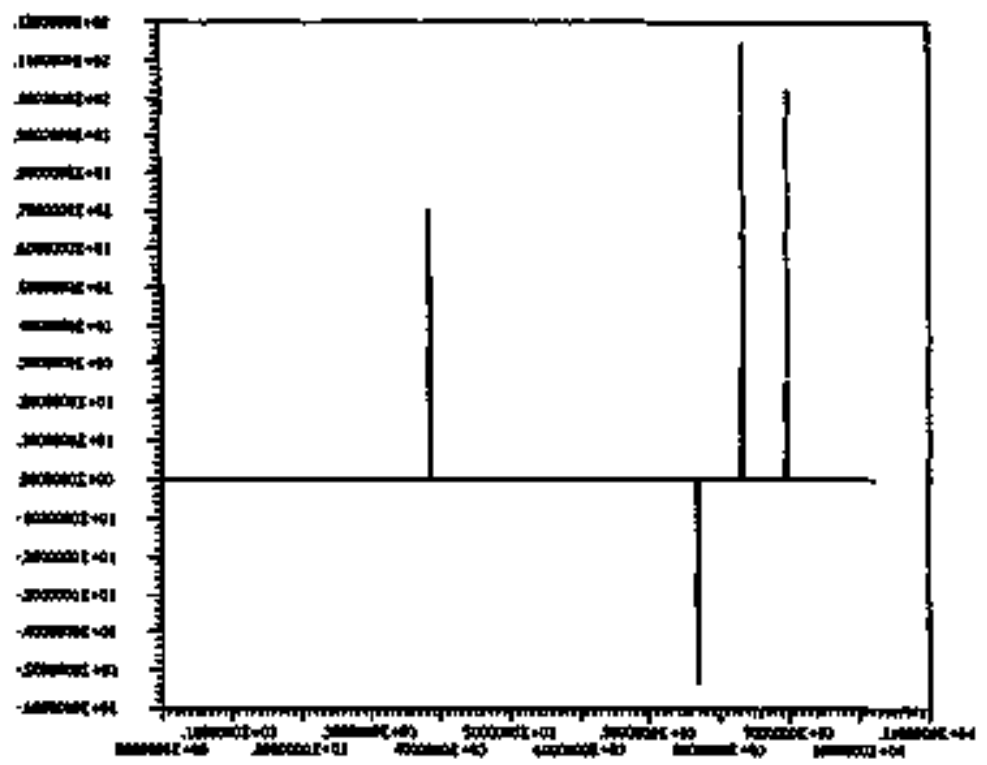



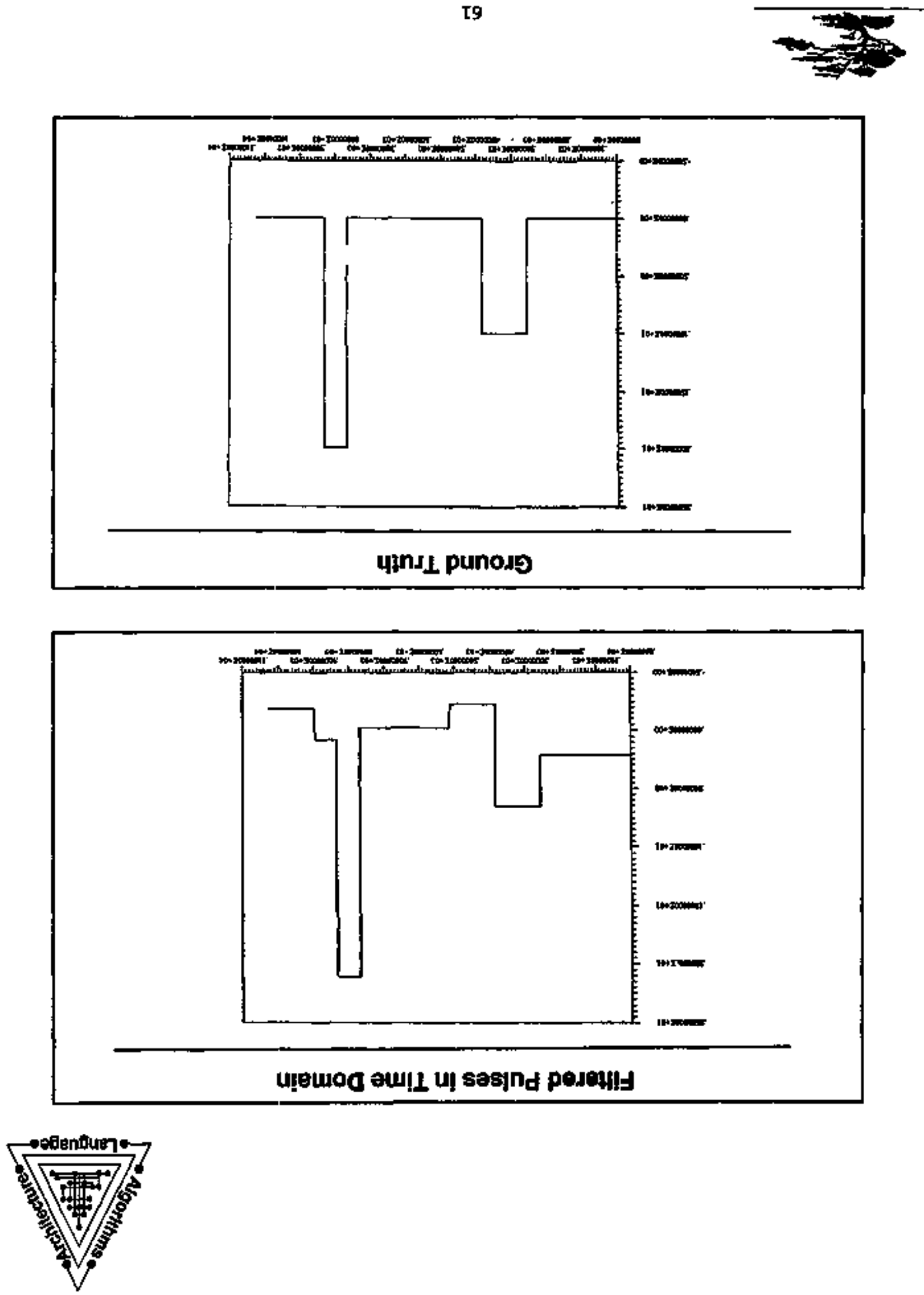

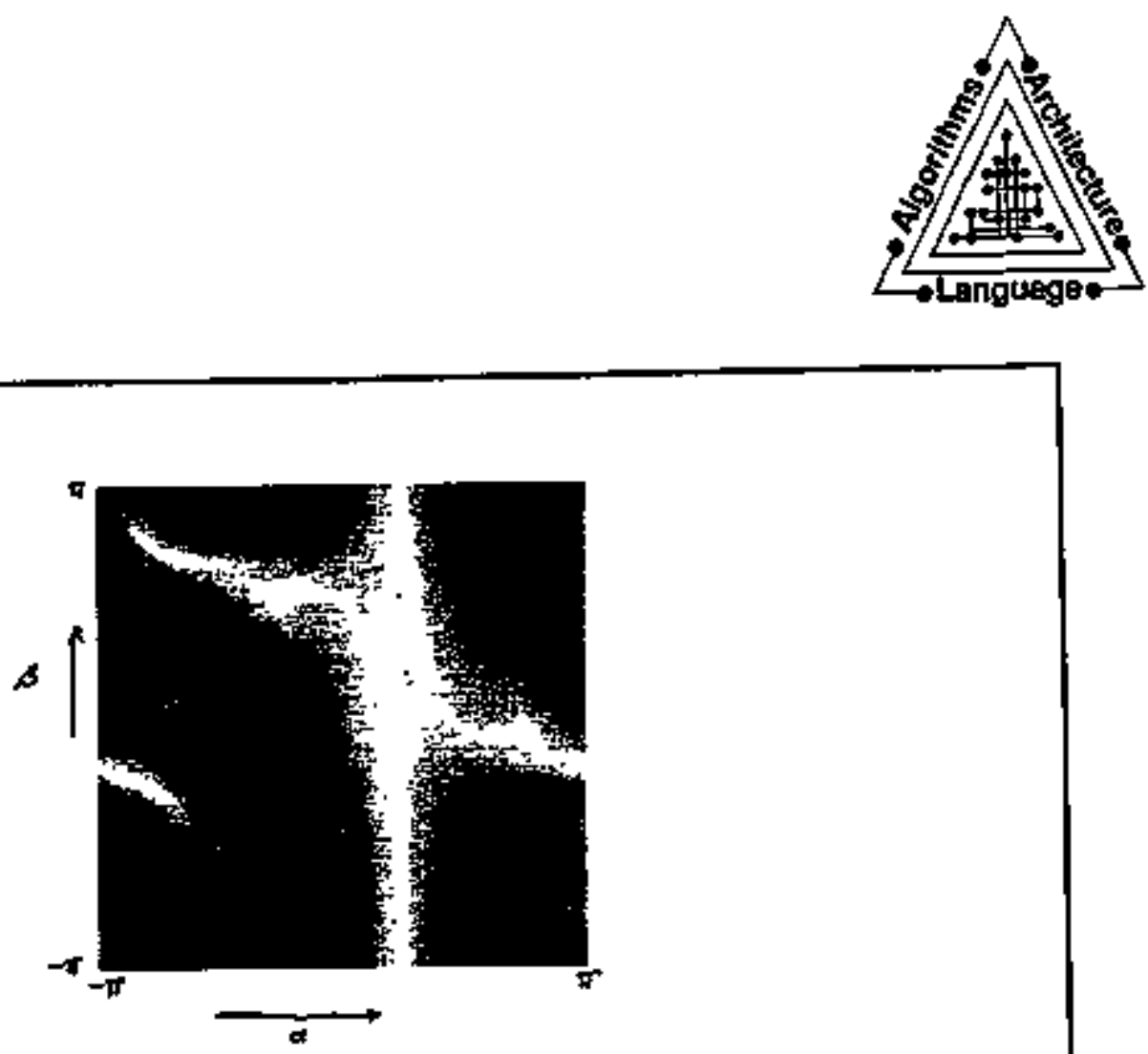

White a Nourly Contionous

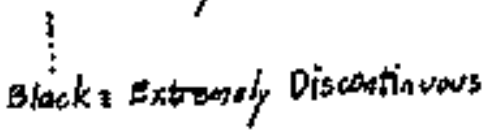

Examples of Wavelets
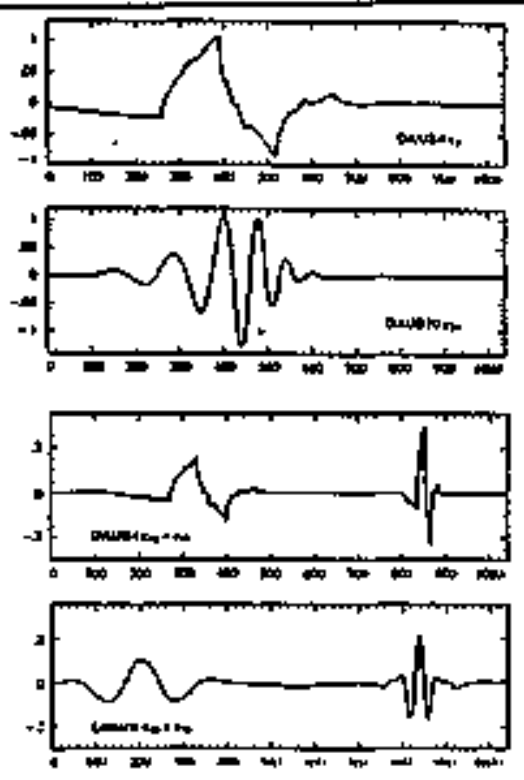

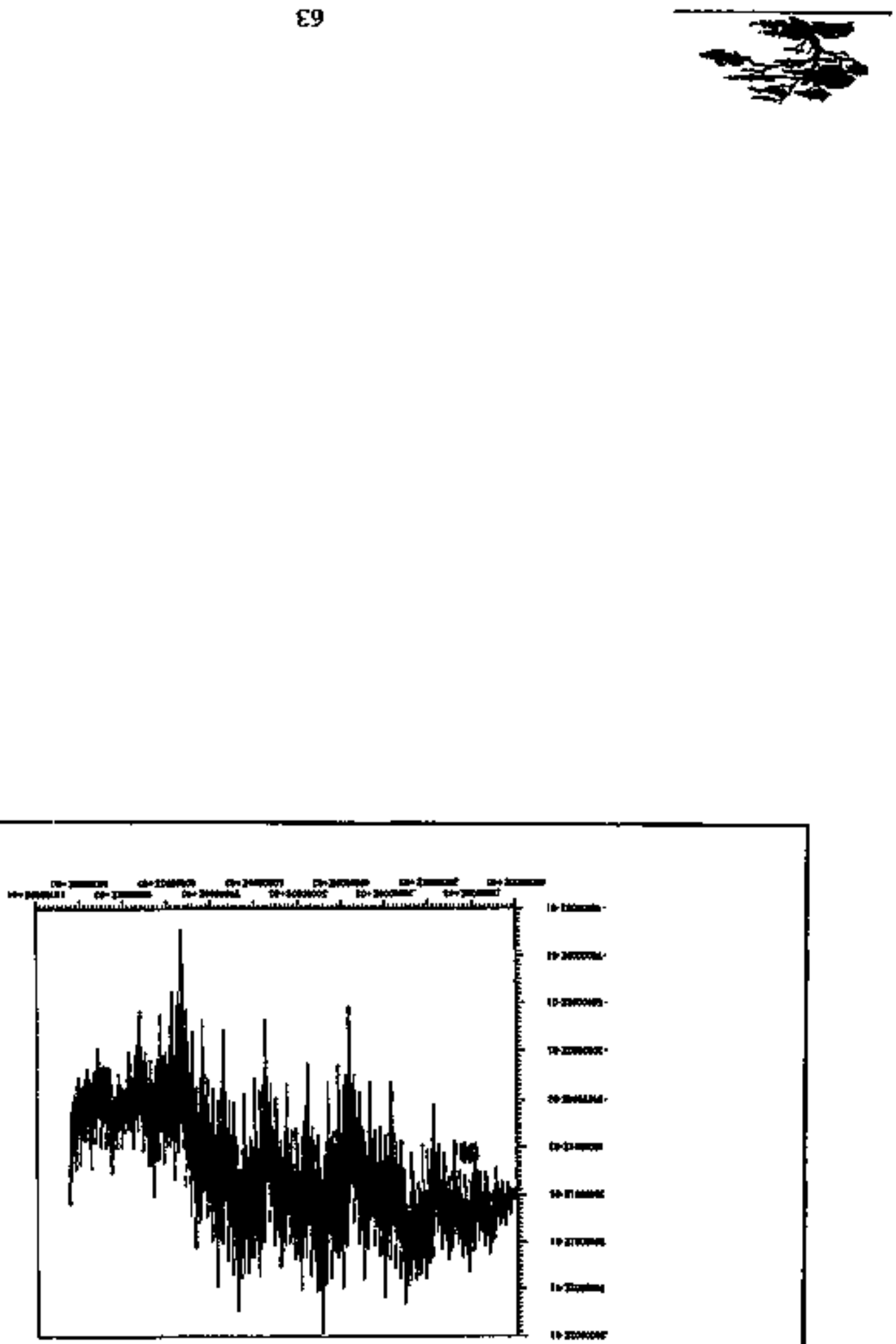

\section{f클 $M$ snonujuossid $\forall$}

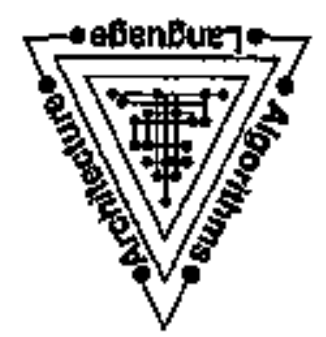




\section{BEYOND LITHOGRAPHY: \\ Molecular Manufacturing and the Future of Computing}

Ralph Merkle, Xerox PARC

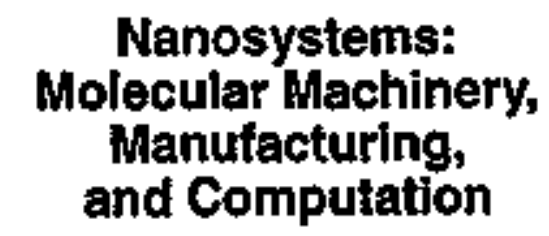

by

K. Eric Drexler

Wiley 1992

Association of American Publishers

Prize for Best Computer Sclence Book of

1992

Second printing planned

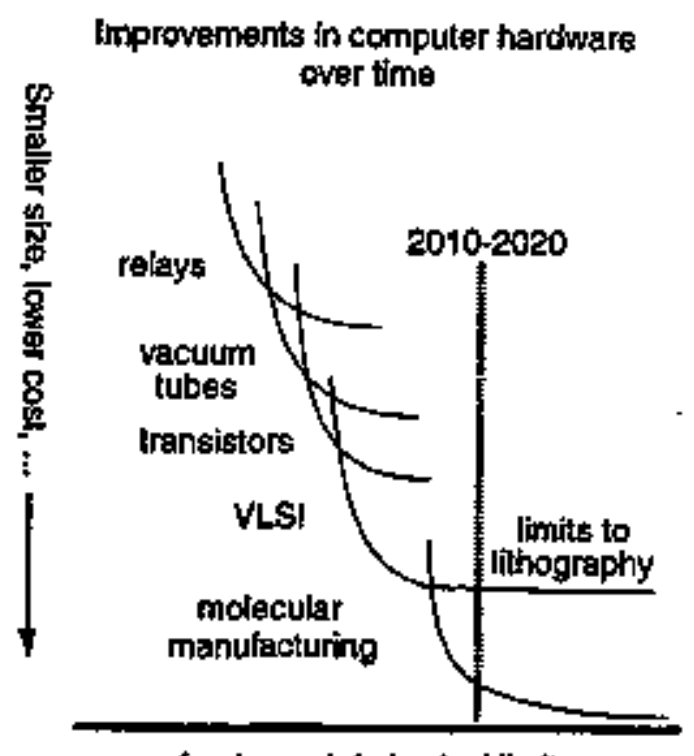

Iundamentai physicsl limits 


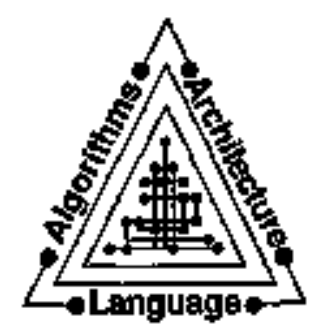

\section{Nanosystems: \\ Molecular Machinery, \\ Manufacturing, and Computation}

by

K. Eric Drexler

Wiley 1992

Associatlon of American Publishers

Prize for Best Computer Science Book of 1992

Second printing planned

First printing:

12,000 paperback

Trends in computer hardware suggest that between 2010 and 2020 we will develop:

1. Mass memory that stores one bit per atom

2. Energy dissipetion per logic operation of $k T$ for $\mathrm{T}=300$ Kelvins (thermal nolse at room temperature)

3. Logic elements with only a few dopant atoms each

4. Manufacturing resolutions of an atomlc diameter 


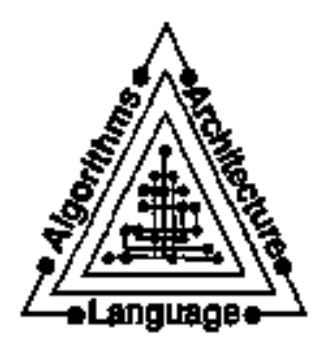

\section{Escalating Cost}

of

Manufacturing Facilities

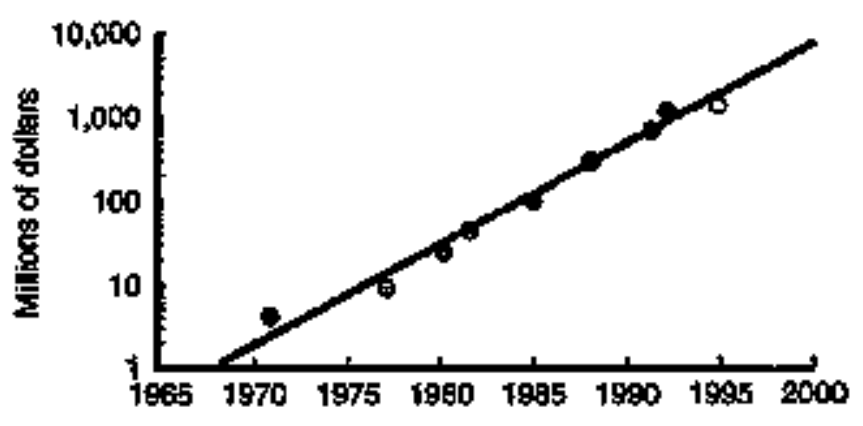

(From Elactronics Now, Beptatinber 27 1993, pape 2B)

Using molecular-beam epitaxy or lịthography for nanoelectronics seems increasingly llke making a suspension bridge by carving it out of a large block of steel.

John Hopfleld, Caltech, 1992 


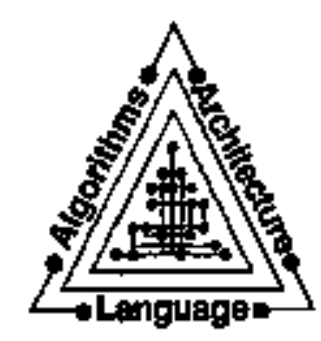

What would happen if we could arrange the atoms one by one the way we want them (within reason, of course; you can't put them so that they are chemically unstable, for example).

Richard P. Feynman, 1959 Nobel Prize for Physics, 1965

\section{Molecular manufacturing}

1. Almost every atom in the right place

2. Manufacturing costs not greatly exceeding the cost of the required raw materials and energy

3. Able to make almost any structure consistent with physical and chemical law 


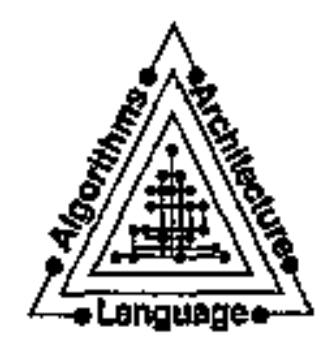

"While speaking to a group of senior naval officers last week, I stressed the need to invest in nanotechnology."

"We want R\&D in things like nanotechnology to continue to keep us ahead of potential enemies."

Admiral David E. Jeremlah, USN Vice Chairman, Joint Chiefs of Staff February 11, 1992

"More specifically, given severe budget constraints, an emphasis toward longterm research makes most sense. In the short and medium term, fairly modest efforts will suffice to maintain our lead in defense technologies. But over the longer term, a more coherent program is needed."

Project 2025 report

November 6, 1991 


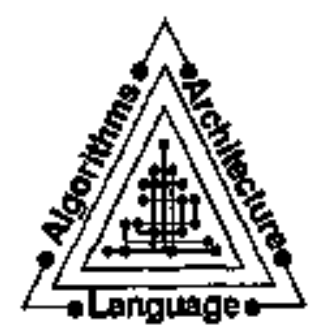

DOO and molecular manufacturing: fundalmental obeervations

1. DOD has a long ( -35 your) planning harizon. Other W.S. orgarrizations with ignlfitant R\&D oapebilitias have planing horizons undar -10 yoars.

2.Trends in computer hardware suggest that molocular manufacturing will be developed in eomewhet over 20 years.

3. Holecular menutacturing wli have a major nconoinic and shratogte impact.

4. There is no focusod roserch aimed at achlaving thls objecture in the U.S. today.

Therefore:

5. DOD has a fundamantal interest in $a$ dlrected program of long range nesepireh athed at doveioping molecular mantifectuting.

\title{
The Major Research Objectives
} in Molecular Manufacturing:

\author{
Design an Assembler
}

Computationally Model it

Bulld It 


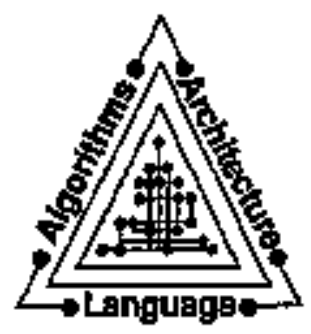

Computational

Experiments

can be used to:

Design and Model

Long Term Goals

(diamondoid systems)

Medium Term Goals

(many possibilities)

Short Term Goals

(aid existing

experimental work)

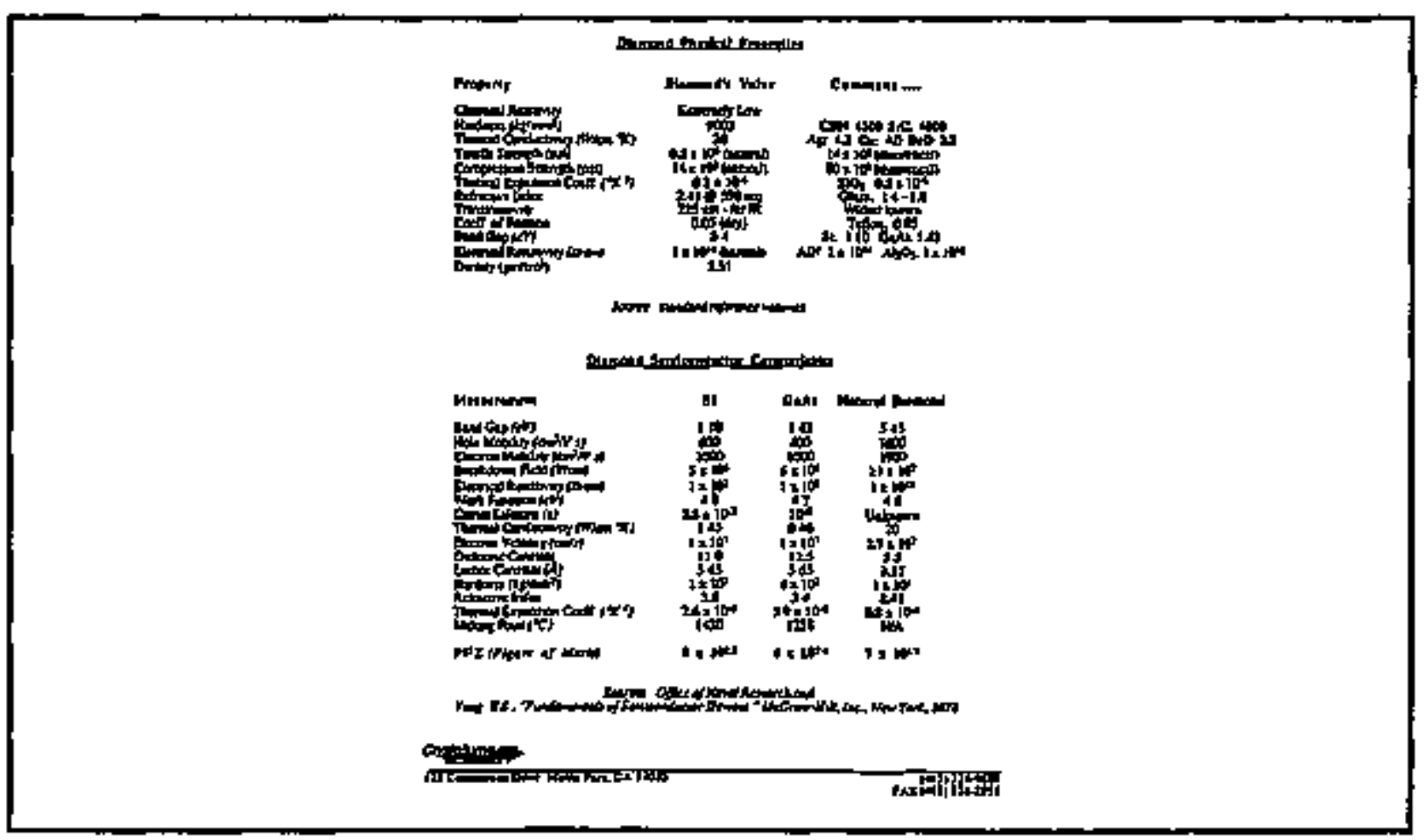




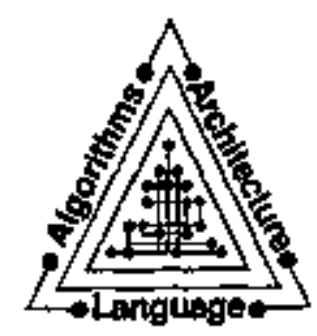

\section{Molecular Manufacturing (slightly simplified)}

1.) Inexpensive

2.) Molecular precision (fewer than one atom in ten billion out of place in properly designed structures)

3.) Make almost any stiff diamondoid structure consistent with the laws of physics and chemistry

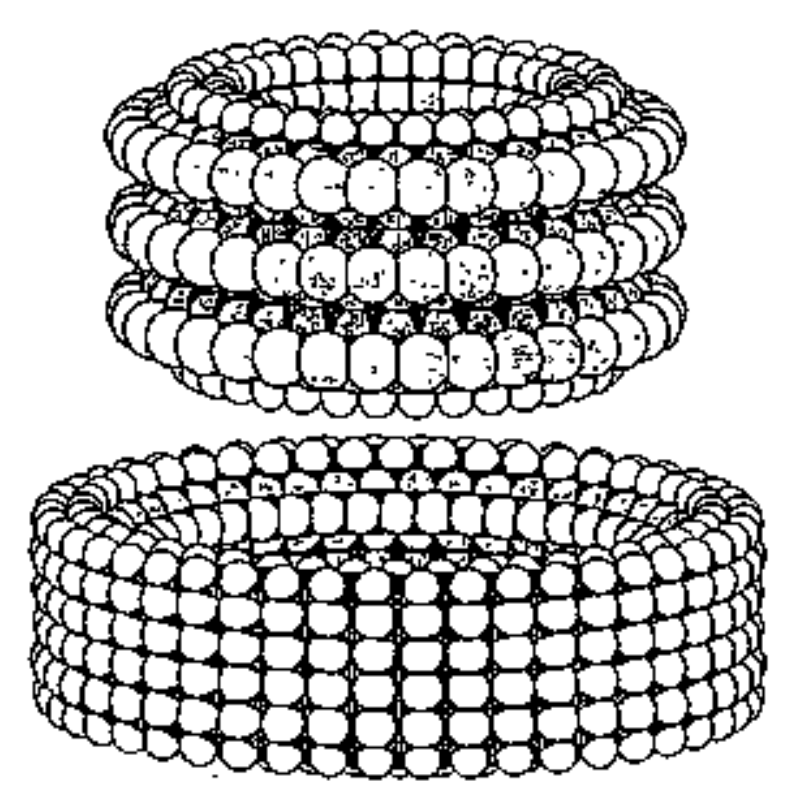



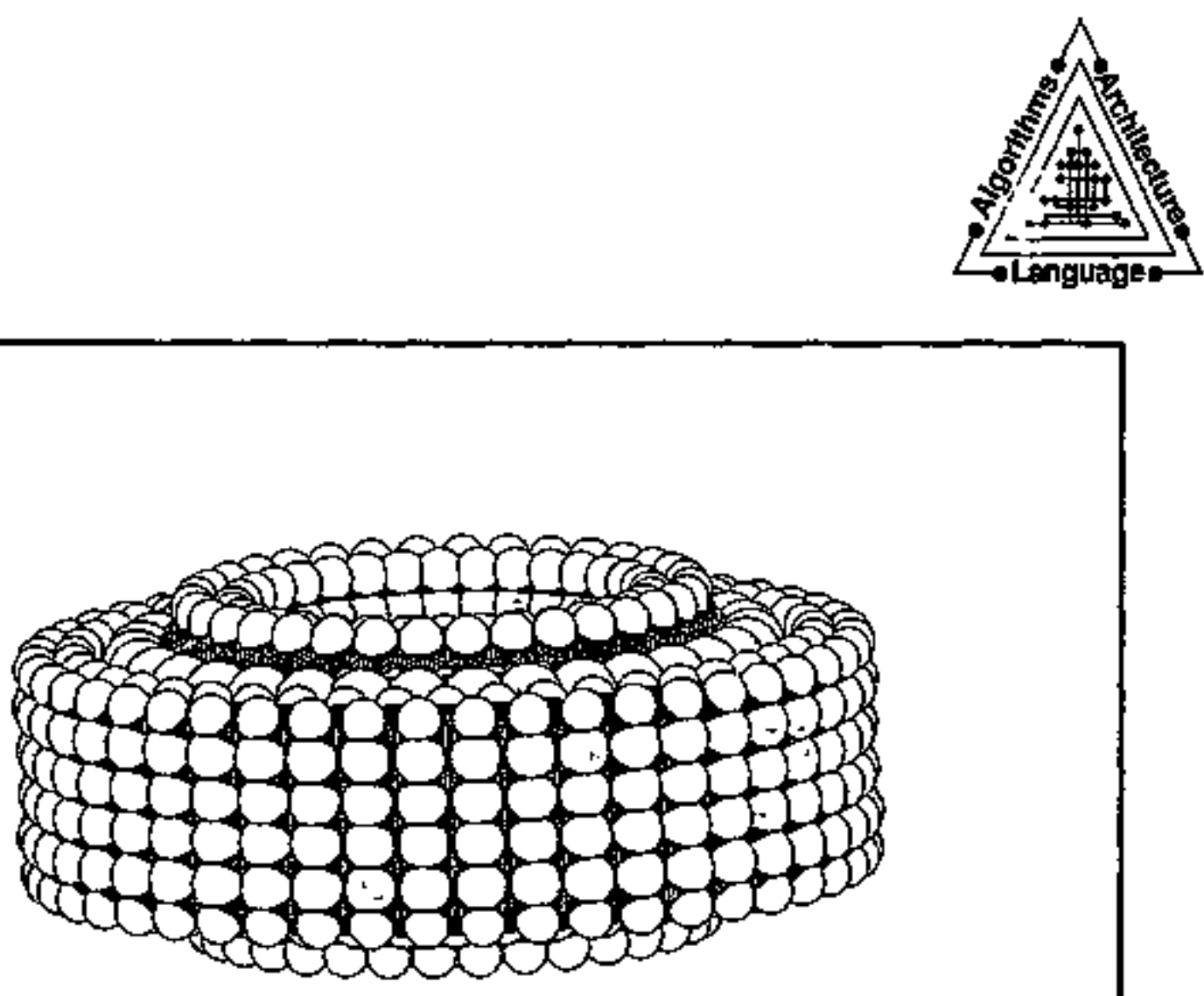

\section{Nanomanipulator for molecular assembly:}

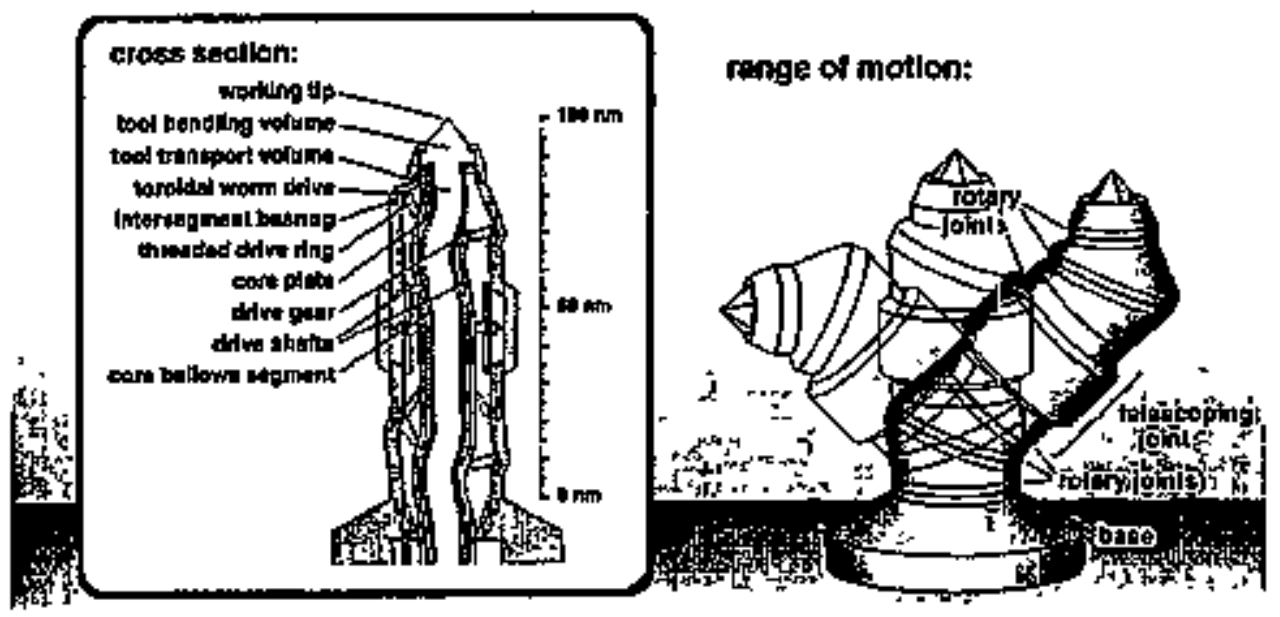

- tubular dlamondold structure

- six drive shafts

- six-axis control

- 10-6 seconds por motlon

- $25 \mathrm{~N} / \mathrm{m}$ bending stiffness

- 4,000,000 atoms 


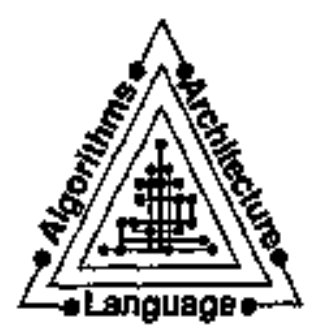

\section{Synthesis of Diamond Today: Dlamond CVD}

1.) Carbon: Methane (ethane, acetylene...)

2.) Hydrogen: $\mathrm{H}_{2}$

3.) Add Energy, producing $\mathrm{CH}_{3}, \mathrm{H}$, etc.

4.) Growth of a diamond film.

The right chemistry, but little control over the site of reactlons or exactly what is synthesized.

$$
\begin{gathered}
\text { A Site Specffic } \\
\text { Hydrogen Abstraction Tool } \\
-\mathrm{C}-\mathrm{H} \quad \cdot \mathrm{C} \equiv \mathrm{C}-\mathrm{C} \text { - }
\end{gathered}
$$

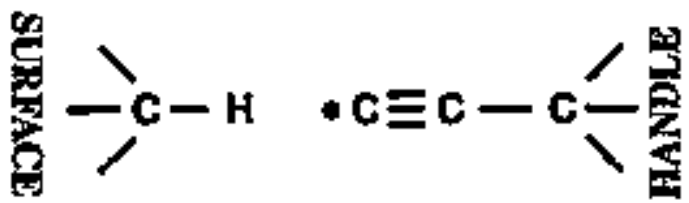

Theoretical studies of a hydrogen abstraction tool for narsotechnology, by Crarles Musgrave et. al., Nanotechnology 2 (1991) pages 187-195. 


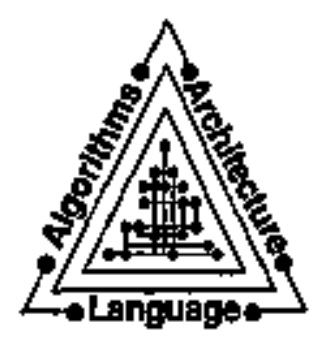

\section{Precursor to a \\ Hydrogen Abstraction Tool}

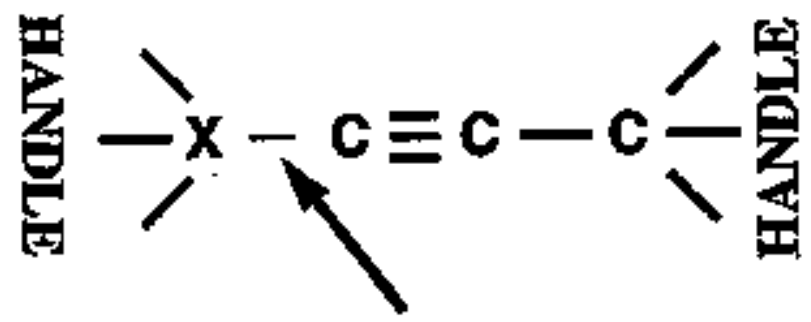

Weak Bond

\section{A Synthetic Strategy For the Synthesis Of Diamondoid Structures}

1.) Positional Control

(6 degrees of freedom)

2.) Highly Reactive Compounds (radicals, carbenes, etc.)

3.) Inert Environment

(vacuum, no side reactions) 


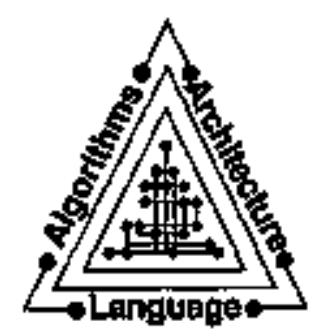

\section{A core concept: self replicating universal constructors}

Von Neumann's architecture:

\begin{tabular}{|l|c|}
\hline UNWERSAL & UNTVEFSAL \\
CONPUTER & CONGTAUCTOA \\
\hline
\end{tabular}

Drexler's architecture:

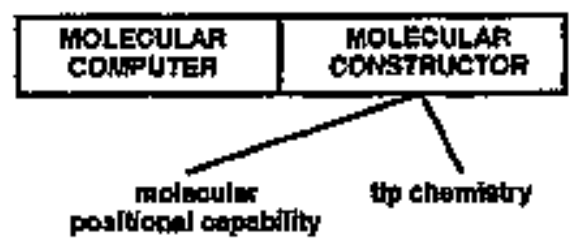

The theoretical concept of machine duplication is well developed. There are several alternative strategies by which machine self-replication can be carried out in a practlcal engineering setting.

Advanced Automation for Space Missions Proceedings of the 1980 NASAASEE Summer Study 


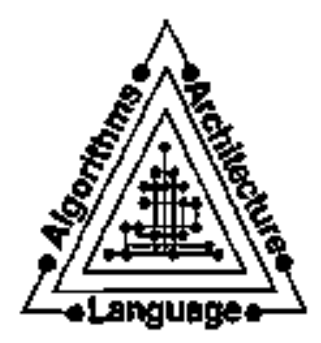

Complexity of

Self Replicating Systems

(bits)

Von Noumann's Unlversal Construetor

Intermet Worm

Myooplasma cepricolum

E. Coll

Drexder's Assembler

Humen

NASA Lunor Manufacturing Faclity about 500,000

500,000

$1,600,000$

$0,000,000$

$1110,000,000$

$6,400,000,000$

over $100,000,000,000$

So I want to build a billion tiny factories, models of each other, which are manufacturing simultaneously, drilling holes, stamping parts, and so on.

\section{Richard P. Feynman, 1959 Nobel Prize for Physics, 1965}




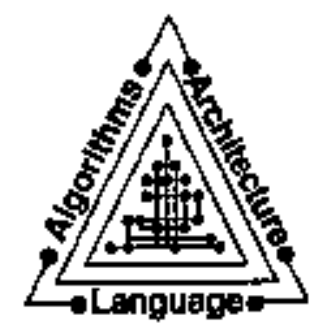

\section{Molecular Manufacturing Today}

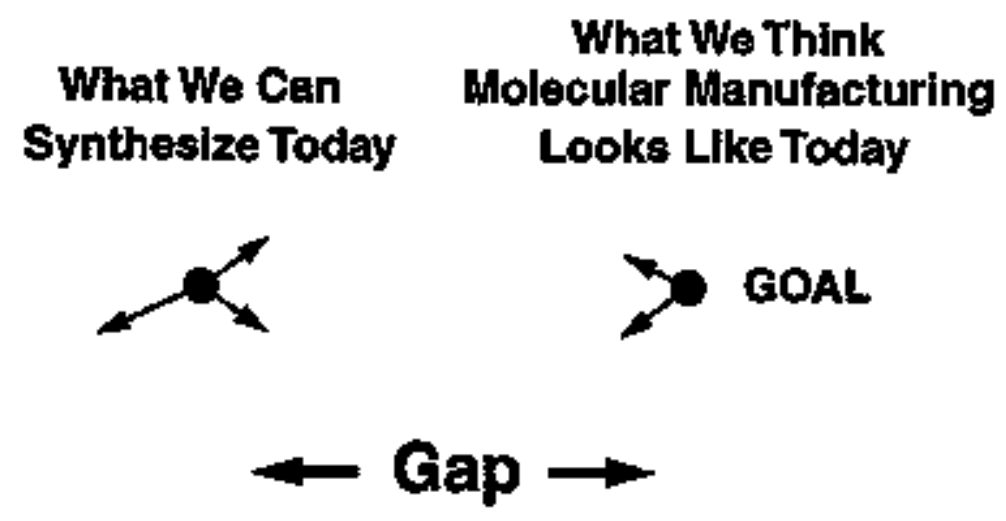

Molecular Manufacturing:

A Poor Approach

For Closing the Gap

Ertond only

what we tan

Bytlyostra:

Experiment alone

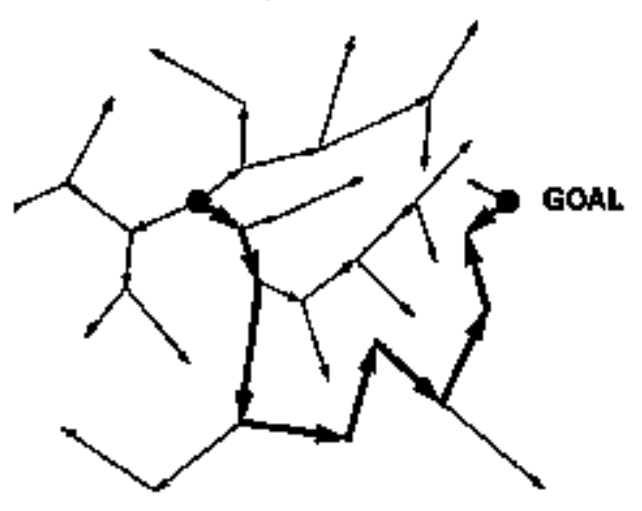




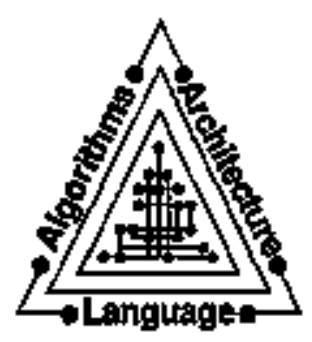

Molecular Manufacturing:

A Better Approach

For Closing the Gap

Extend both

whot wo oan

eynlheastion

and

what wo can model

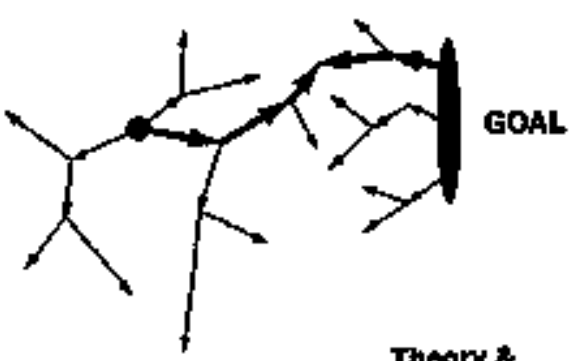

Experiment

Compustations

Experiments

\section{Problems to Avoid}

Finding the lowest energy

conformation among the many possible for floppy molecules

can be computationally intensive.

Solution: The use of stiff

molecules (bricks) can avoid

this. 


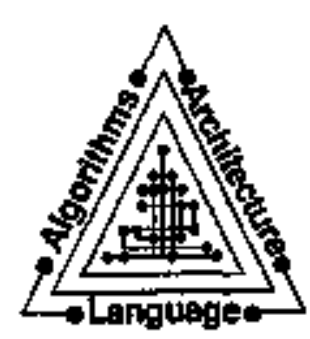

\section{Problems to Avoid}

Radlation will cause damage and errors.

Solution: Radiation shielding is difficult. Instead, assume that background radiation is unavoidable and causes a certain error rate. This error rate still permits systems wlth tens of billions of atoms with a mean time between radiation hits of many decades. Design systems that tolerate this error rate.

\section{Problems to Avold}

Light can cause photochemical reactlons and photochemical damage.

Solution: Keep it in the dark. Even a thin layer of metal (a few hundred nanometers) will reduce photochemical damage to below radlation damage.

An alternative approach

(somewhat more complex): design the system to be light tolerant (transparent). 


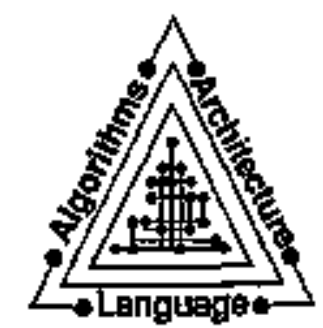

\section{Problems to Avoid}

Thermal noise can cause damage.

Solution: Design the system so that transitions from a correct state to an incorrect state have barriers that are large compared with $k T$.

To achieve thermal error rates at room temperature comparable with radiation damage, barrier heights should be about 300 to 400 mad ( 350 maJ is about 2.2 electron volts, or 50 kcals' mole).

\section{Problems to Avoid}

Computational models can produce the wrong answer if the actual pinysical system differs from the abstract system (due to contaminants, e.g., unexpected atoms in unexpected places).

Solution: deal with all contaminants at the system boundary. Robust barrlers that tolerate external contaminants and keep the internal envlronment well ordered are easier to design than complex systems that tolerate dirt. 


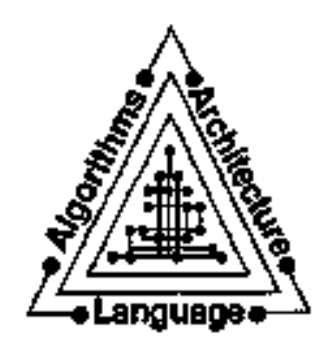

\section{Problems to Avoid}

Thermal noise: thermal vibration can cause significant positional errors. This is of particular importance in the design of positional devlces.

Solution: if it's not accurate enough, make it bigger. Scaling laws mean bigger objects are stiffer, and hence less subject to thermal noise.

\section{Problems to Avoid}

Modelling errors: the system design must work despite the use of an imperfect model.

Solution: Robust designs that work in the face of expected modeling errors must be used. In many cases, this can be viewed as designing for a hightemperature environment. Thermal errors and errors caused by the model can be viewed as abstractly similar. 


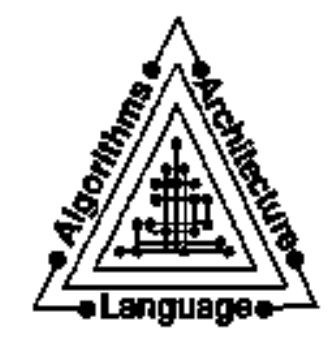

Many of the questions raised by the design of an assembler can be answered

By experiment

By computational chemistry

By a combination of both

Computational chemistry

is a historically unique tool which lets us pose and answer

questions inaccessible to present experimental methods. This makes it of unique value in planning the molecular manufacturing systems of the future.

\section{Computational Nanotechnology:}

\section{Model future molecular machines using today's computational chemlstry software.}

Feasible for devices that are difficult or impossible to make with today's methods.

Speeds development of better systems

Rapidly revlew and discard dead ends

Inexpensive

Informative 


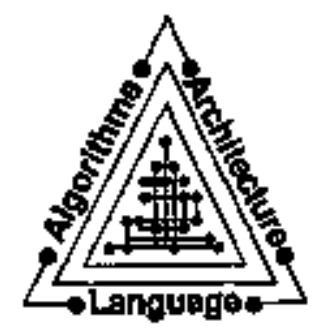

\section{DESICN AND FABRICATION OF THE FIRST \\ MOLECULAR MANUFACTURING SYSTEAS \\ WLL REQUIRE EXPERTISE IN:}

Physics

Robotics

Chemistry

Surface Sclence

Materials Science

Computer Science

Electrical Engineering

Mechanical Engineering

Computational Chemlstry

\section{The best way to predict the future is to invent it.}

\section{Alan Kay}




\section{STUDYING OCCUPATIONAL HAND DISORDERS}

Frank R. Wilson, M.D., University of California

George P. Moore, Ph.D., University of California

Humans have established a powerful hold on their cnvironment largely because of the exploitation of novel shill potentials created by the handbrain marriage. During the latter part of the 20 th century, computermachine techinology has been widely exploited in the workplace to achieve accuracy, efficiency, and economy in tasks dominated by rapid, stereotypic movement sequences. Although robatics remains a rapidly growing industrial science, comptterized mochines designed simply to augment human motor performance have not been the whqualified success designers and users had hoped. The computerized human worker does not always behove as expected.

During the past decade, the incidence of work-related repctitive motion disorders has more than ipled from approximately 6 to 21 per 100,000 workers, making them now responsible for more than one-half of all occupational disorders reported in the United States' Ainong the most commonly reported of these are temosynovitis and tendinitis, nerve entrapnent syndromes (especially the corpal and cubital tunnel syndrones) the hand-arm vibration syndrome, ${ }^{2}$ and reflex sympathetic dystrophy. Operators of electronic keyboards (especially at computer work stations) comprise an especially fast-growing group of individuals disabled because of hand and arm complaints. Another group increasingly coming to attention are performing artists (especially advanced, instrumentol music students and orchestra musticions). The study of the latter group has yielded improved widerstanding into the cause of some forms of occupational hand disorder."

These unexpected difficulties have contributed to a new generation of rescarch guestions in motor control, and may reguire novel strategies and assessment tools. As ergononists search for wrys to improve the "fit" between humans and machines, and as computers (and employers) drive workers toward higher output, it becomes increasingly apparent how litile is actually ktown about the biomechonical and neurophysio. logical correlates of human shilled - especially manual - movement. 


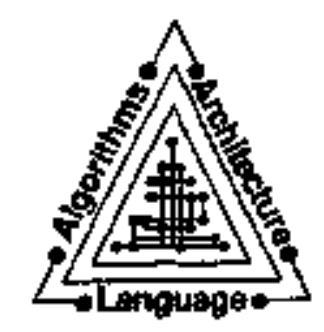

We will briefly review the history of occupational hand disorders and will introduce the results of preliminary studies of timing anong highlevel musicians experiencing loss of musical performonce shill Initial experience with these studies suggests the possibility of significant new trends and opporunities in research on biomechanical and neurophysiologicol processes in human skilled movement.

The following are antong the more noteworthy implications:

- MIDI devices and software developed to control them represent a high level and comparatively inexpensive technology readily available and appropriate for study of the control of hand movement;

- individuals with motor impairments (including extremely large populations of patients with congenital and acquired neurologic disabilitics) comprise a huge untapped subject population for clinical research and client population for cognitive and motor rehabititation efforts;

- improtements in miniarurized, fast, accurate position sensors and physiologic transducers, as well as supporting software, are needed, as are devices for more detailed study of hand biomechanics;

- compurer modeling of biomechanics and neuromuscular controt will probably be essential for the stitdy of muscle synergies in upper extremity movement. 


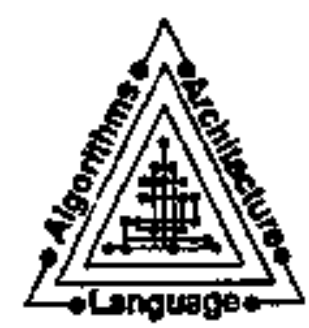

1. A brief anthropologic oerspective on the "modem hand"; 1roglodytes, Lusy. and bevond - a modem version of the Prometheus muth! All understanding of disturbances of the origins of hand and am problents presupproses an appreciation of the nomal operation of the entire upper extremity, including shoulder and scapular movement, elbow and wrist function, and the special features of prehensile and non-prehensile movements of the buman hand. The human hand differs from the ape hand in several important ways: the thumb is longer in relation to the phalanges in humans, permitting greater contact between palmar surfaces of the thumb and finger tips; greater axial rotation occurs at the MP joints of the digits, permitting a "3-jaw chuck" (baseball) grip and "5-jaw chuck" grip; the ulnar side of the band can be opposed to the thumb, permitting an obligue grasp of a shaft and thereby permitting the long axis of the arm to be greatly extended.

Other modificatsons in wrist bones (especially the capitate) and ligaments permit dispersion of impact forces delivered through the long axis of the central metacarpals. Most of these changes were present in the hand of Australopithecus afarensis 2.4 million years ago; the hand of Homo sapiens sapiens differs mainly in the increased pronation and opposition of the thumb and greater axial rotation of the 4 th and 5 th fingers, and their capacity for opposition. The increase in functional capacity of the hand as a result of these "minor" changes. however, probably explains the enormous expansion of manual skill of humans over other primates, the exceptional capacity to make and use refined tools, and possibly to some extent even the thee-fold increase in brain size that followed the advances over earlier primate forms found in Lucy's hand. $5,6,7,8,9$ 


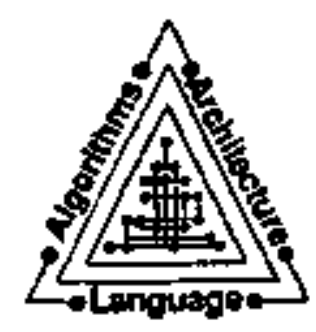

2. Eunctional analony of prehersioni In a landmark paper published in 1956, anatomist J.R. Napier establjshed the first anatomical-functional classification of hand movements. ${ }^{10}$ Furst, he separated "prehensile" from "non-prebersile" movements. Prehensile movements are those in which an object is held partly or wholly within the hand; non-prehensite moveryents are those in which the object is manipulated by the hand of fingers, but not seized or grasped. Combing one's hair is an example of the former; typing or playing the pjano is an example of the latter.

Within the prehensile group, Napier distinguished two kinds of grip: the "power grip," in which pan of the object is held by fingers and/or thumb against the palm; and "precision grip," in which the object is pinched between the thumb and any of the other fingers, without touching the palm.

Another power grip is a canying or "porter's" grip, also called a "hook" grip, in which the fingers do most of the work without the thumb - doing chin-ups, and carrying a briefcase use this kind of grip. What is interesting about this grip from an anthropologic point of view is that it does rot require supination of the ulnat side of the hand, and therefore control of the object is very crude. As Mary Marzke points out, non-human primates, includting A. afarensis, are limited to this kind of power grip."

2. The term "prethension" comes from the Latin word meaning "to stize," and does not quite do justice wo the vatiety of uses to which lbe hand con be pux to object manipulation ind cancrol. 


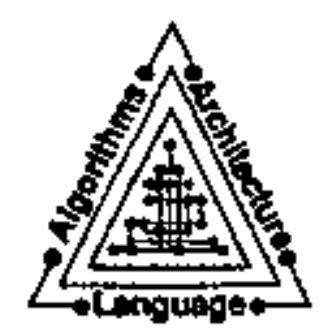

Subsequent classifications have added refinement and modifications to Napier's system. Ellitott and Connolly proposed use of the terms "intrinsic" and

"extrinsic" to distinguish between movements in which the object is manipulated within the hand (intrinsic) and movements in which the object is "displaced by the hand as a whole, using the upper limb."

Elliott and Connolly proposed a further subdivision of intrinsic hand movements into those involving simple or reciprocal synergies and those using sequential pattems. Simple synergies involve simple flexios of the thumb and fingers, as in handwriting; reciprocal synergies involve separution of the thumb from the movements of the other fingers, as in tightening a nut; sequential step movements involve complex rotary movements, like turning a combination lock or manipulating knitting needles and yam.

Less attertion has been pajd by scientific writers to non-preliensile movements, but the increasing prevalence of occupational injuries related to keyboard use witi change that. There is in fact a very large body of technital literature on these movements, but the soutce is Iargely within the domain of professional tenching of keyboard and musical insirument use. Unfortunately this pedagogy is for the most part entirely empirical. The Hand Book, written by a concert pianist, has recently been published and suggesis that concepts drawn from high level musical instnument study could be have a favorable impact on the present epidemic of compster keyboard injurites. ${ }^{13}$ 


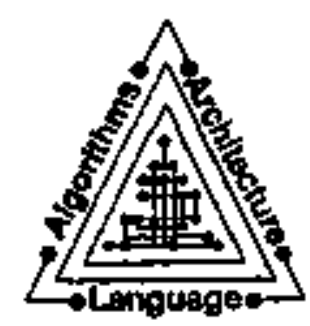

3. Recent studies of unner extremiry biomechnnics - what we have leamed from musicians with occupational cramp: In a series of English language publications beginning in 1974, Christoph Wagner provided details of the static and dynamic characteristics of movement in the upper extremities of musicians whose ages range from 16 to 72 years, and who play virtually all instruments in common use. ${ }^{14.55} 16$ The tole of joint bypermobility in musical performance has recently been studied at a major American conservatory. ${ }^{17}$ In general, these studies have indicated that unessual biomechonical pre-conditions are associated with recurrent pain syndromes of the upper extremity. Most prominently, stringed insirument players with chrontc forearm pain have a higher than expected incidence of low supination range at the elbow; keyboardists with forearm pain, by contrast, have a higher than expected incidence of low pronation range at the forearm. Because of the limited availability of quantitalive measures of upper atm biomechanics, the contribution of such abnormalities among office and indusirial workers with repetitive stress injuries is unknown.

4. Musical vamps and manual cramps. Even more disabling than repetitive stress injury is the syndrome of occupational cramp. A recent study reported by Wilson, Wagner and Homberg links biomechanical abnormalities to the establishment of a "learned motor disorder," and to other tisk factors, including repetition rates and psychological factors. ${ }^{18}$ Moore's studies of timing and muscle activation in performance of trills on the cello and piano establish the feasibility of simultaneous recordings of movement and muscle activation in musical performance. ${ }^{19.20 .21}$ The recent adaptation of MIDI (musical instrument digital interface) technology creates both new opportunities and new problems 


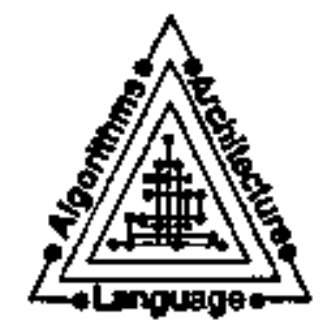

in that regard. ${ }^{2}$ We are now seeking ways to use these new methods to examine movements in which there ate proven disturbances in the physiologic conarol af reciprocal inhibition of flexion-extension movements of the fingers, a hallmark of writers' cramp and related disorders. ${ }^{\text {2.,2u }}$

5. Treatment and prevention. The vbiguity and intraclability of occupational band cisorders has generated a vigorous response from both indusiry and the medical community. Some prevention strategies (focusing on work station ergonomics) appear to have been helpful, and modification of work habits (including upper body and limb posture during movement) have been helpful in many cases. Individual biomechanics have not been addressed (as they are beginning to be among musicians), and physiologicatly rational training for computer-operated keybourds remains a latgely unmet challenge in injury prevention. 


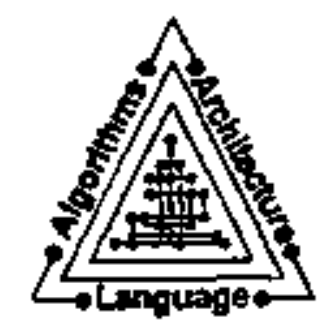

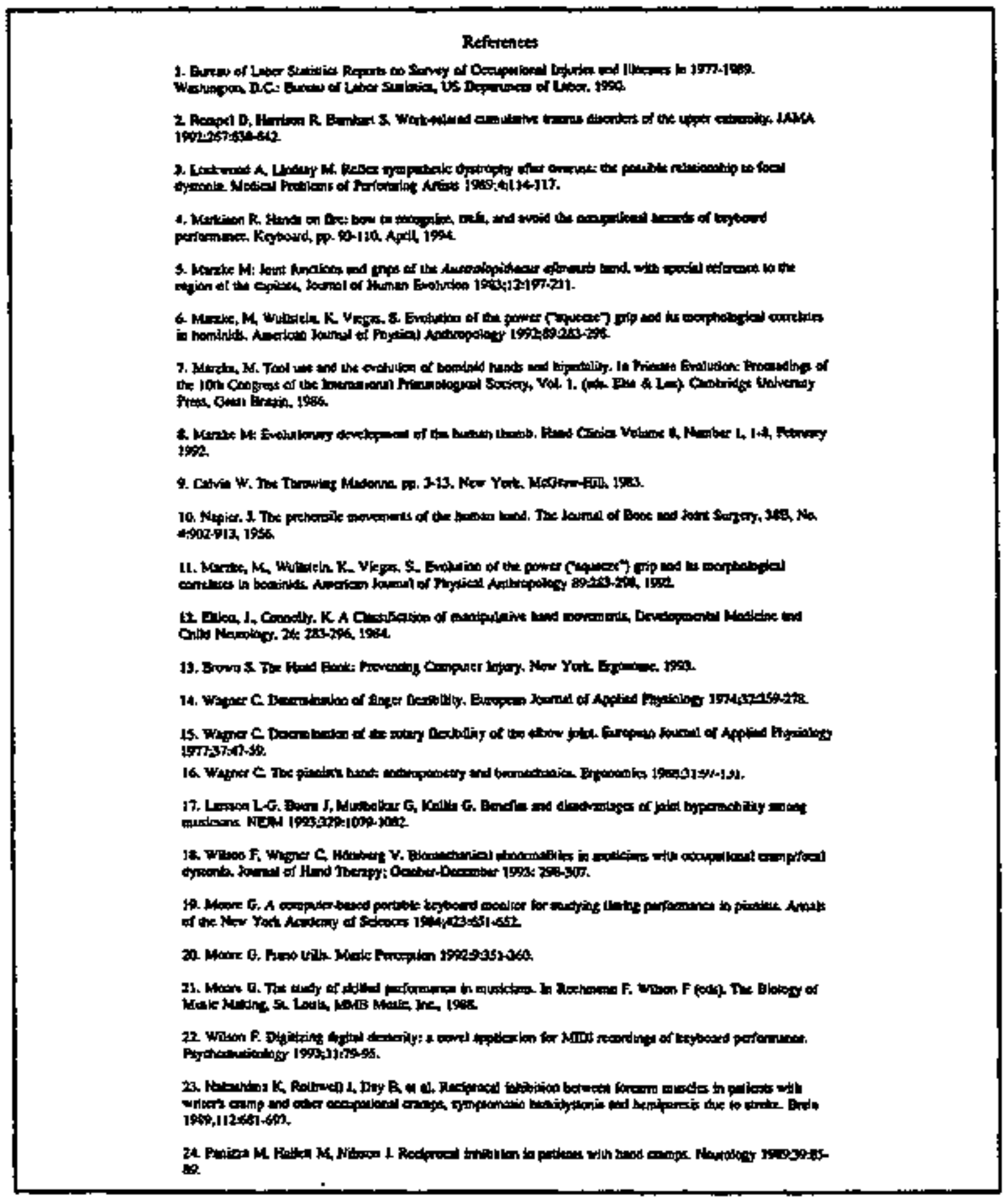



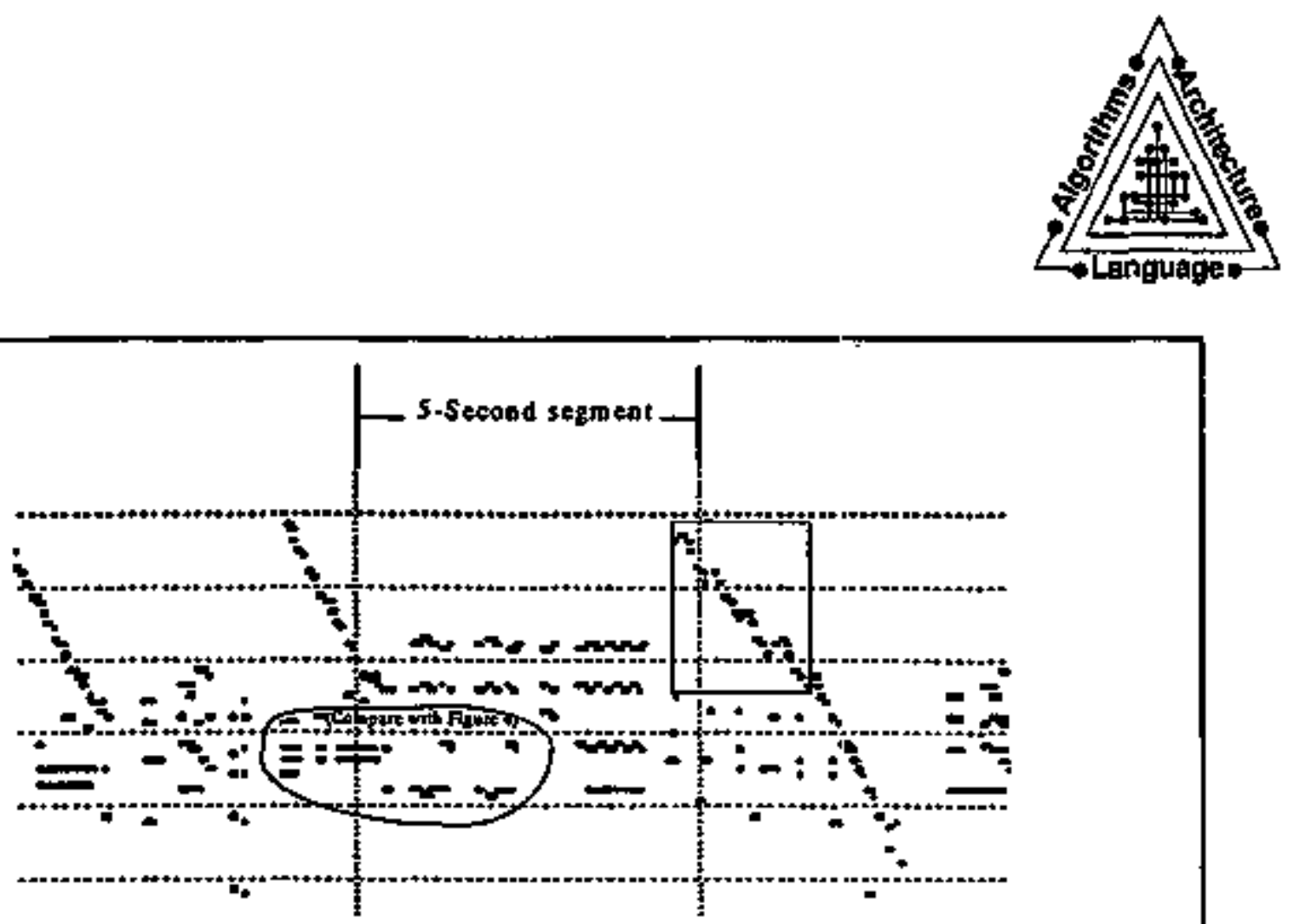

Figure 1. Pianist UD. Utodited 15 -second sepment Chop in B min Sonz19. Note descending funs, 2-sectad segment of third rut o (gesy box) is $\mathbf{2 5}$ notes long and is reproduced in following figures. Reproduced frow Psychomssticalogy 1993;1 1:79+95.

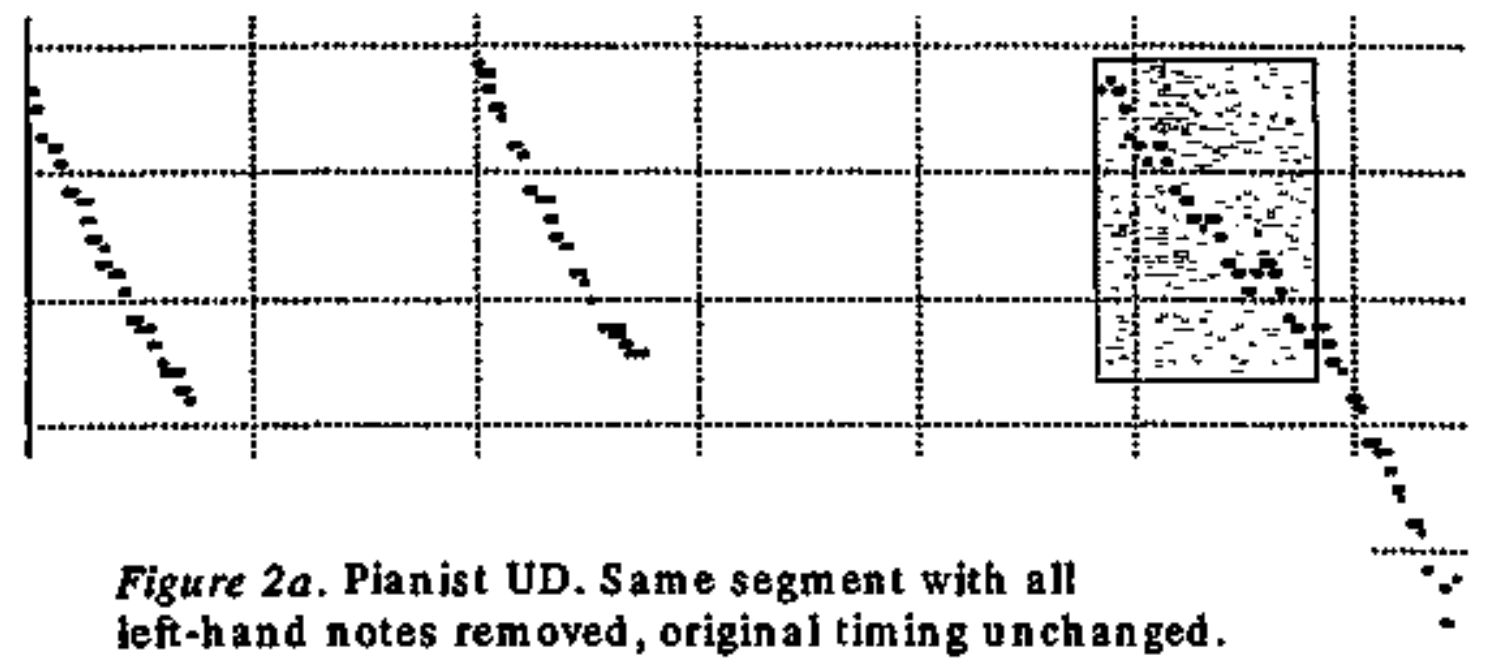



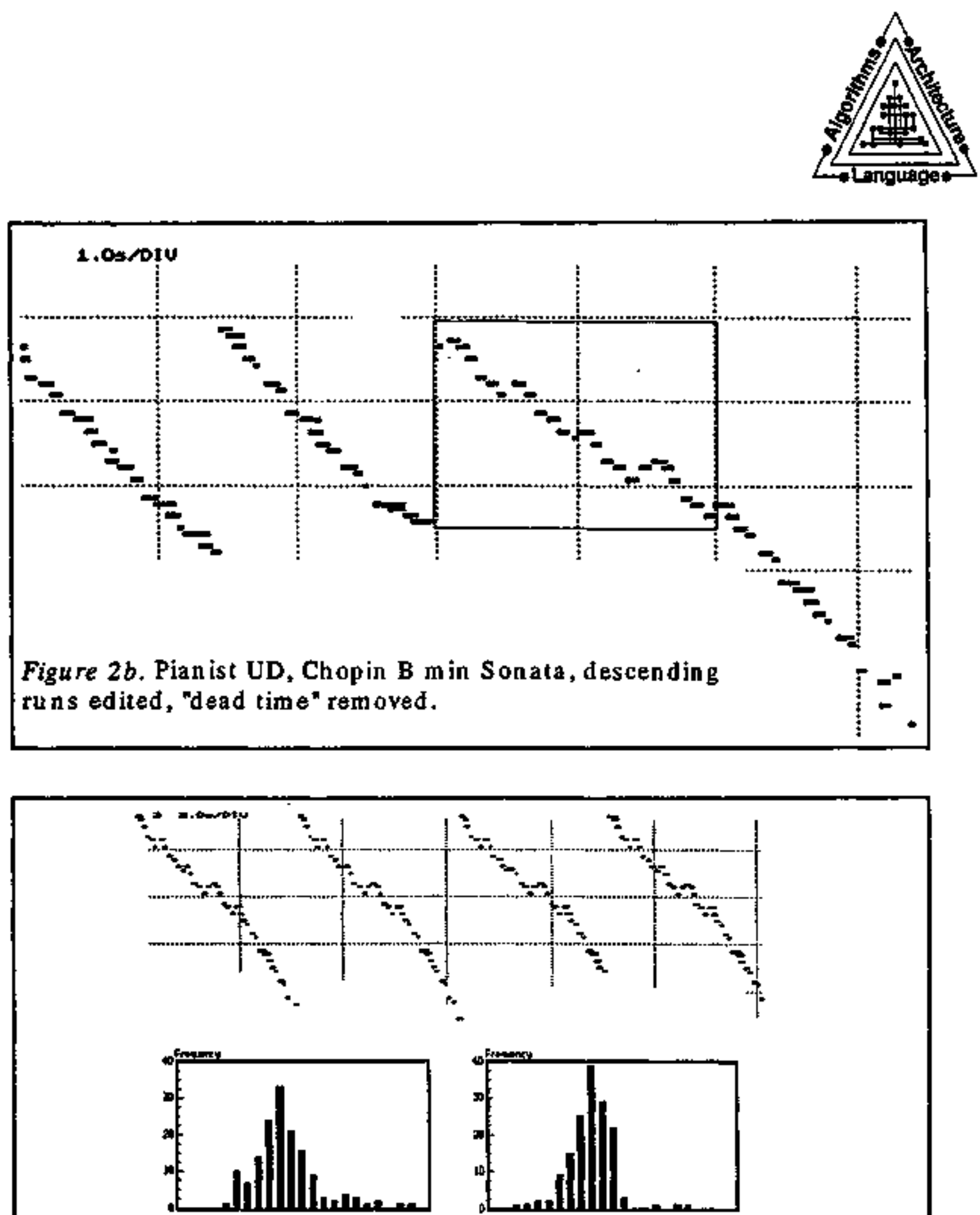

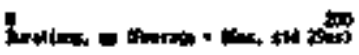

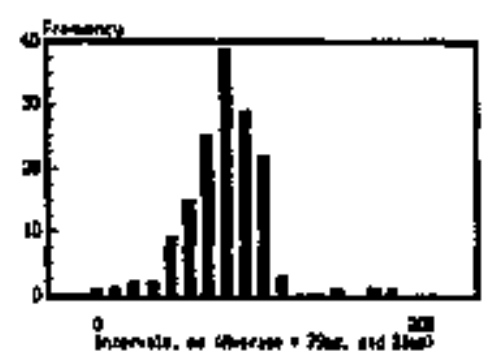

Figure 3. Pianist UD, Chopin B min Sonata. Four seccessive pertornances edited to show $\mathbf{3 b}$-note desceading ton with combined note du ration and interval histogers m. 

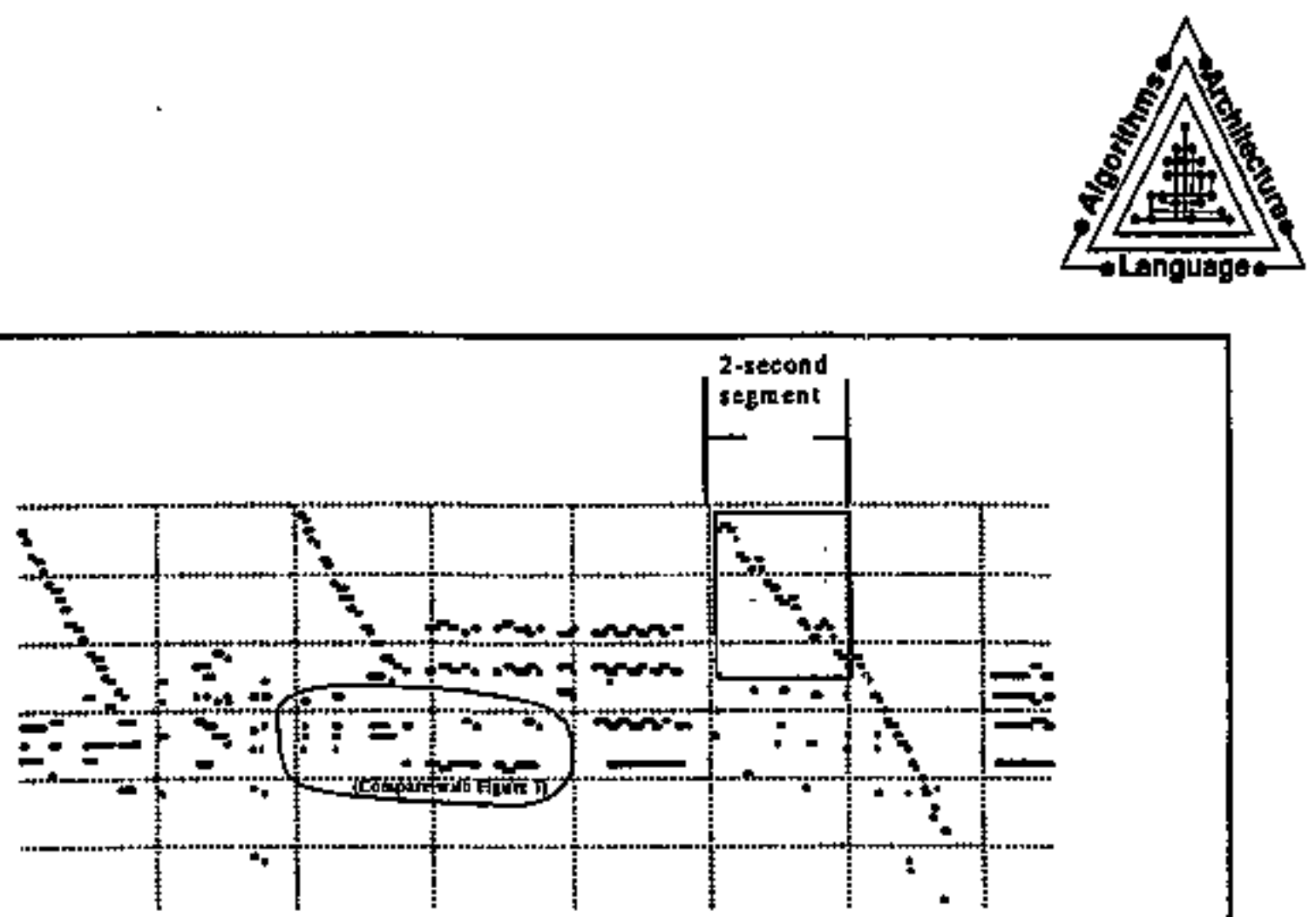

Figure 4. Pinnist PO. Unedited 16-second segment Chopin B m in Sorta. Note detcending runs.
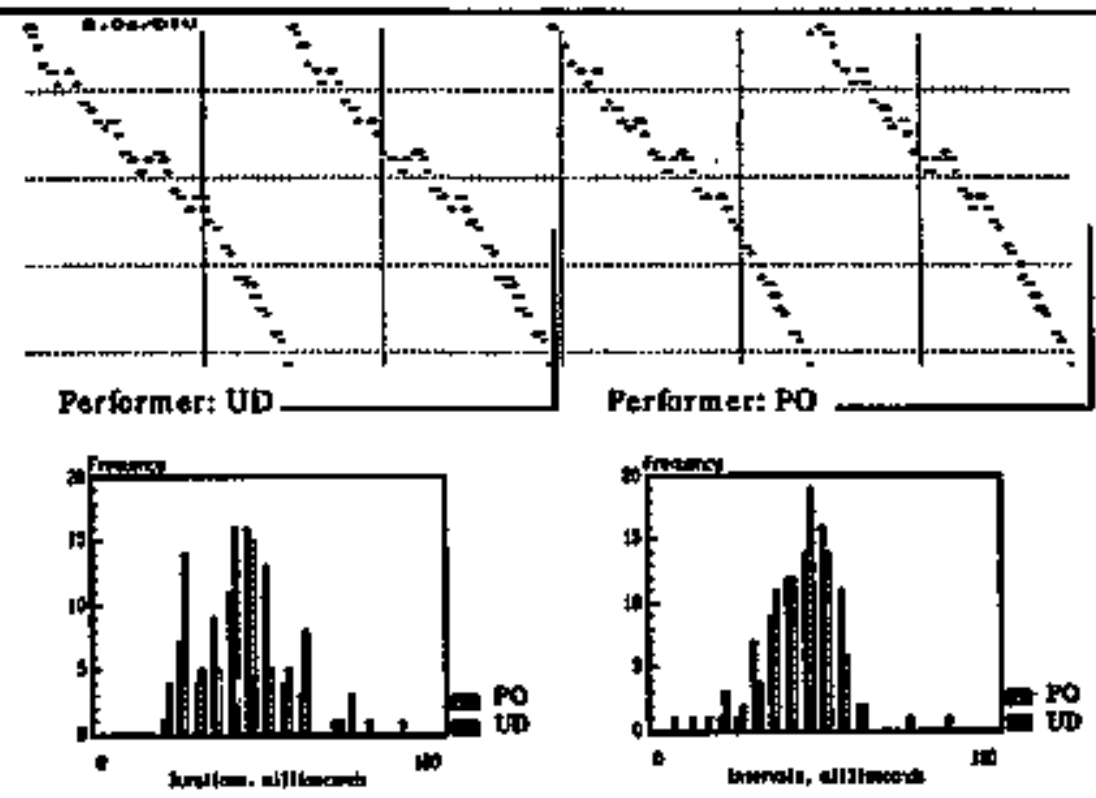

Figure 5. Comparison of pianists UD and PO, two parformances by each of same 38-note descendiag ran in Chapin 19 minor Sonta, with histograms. 

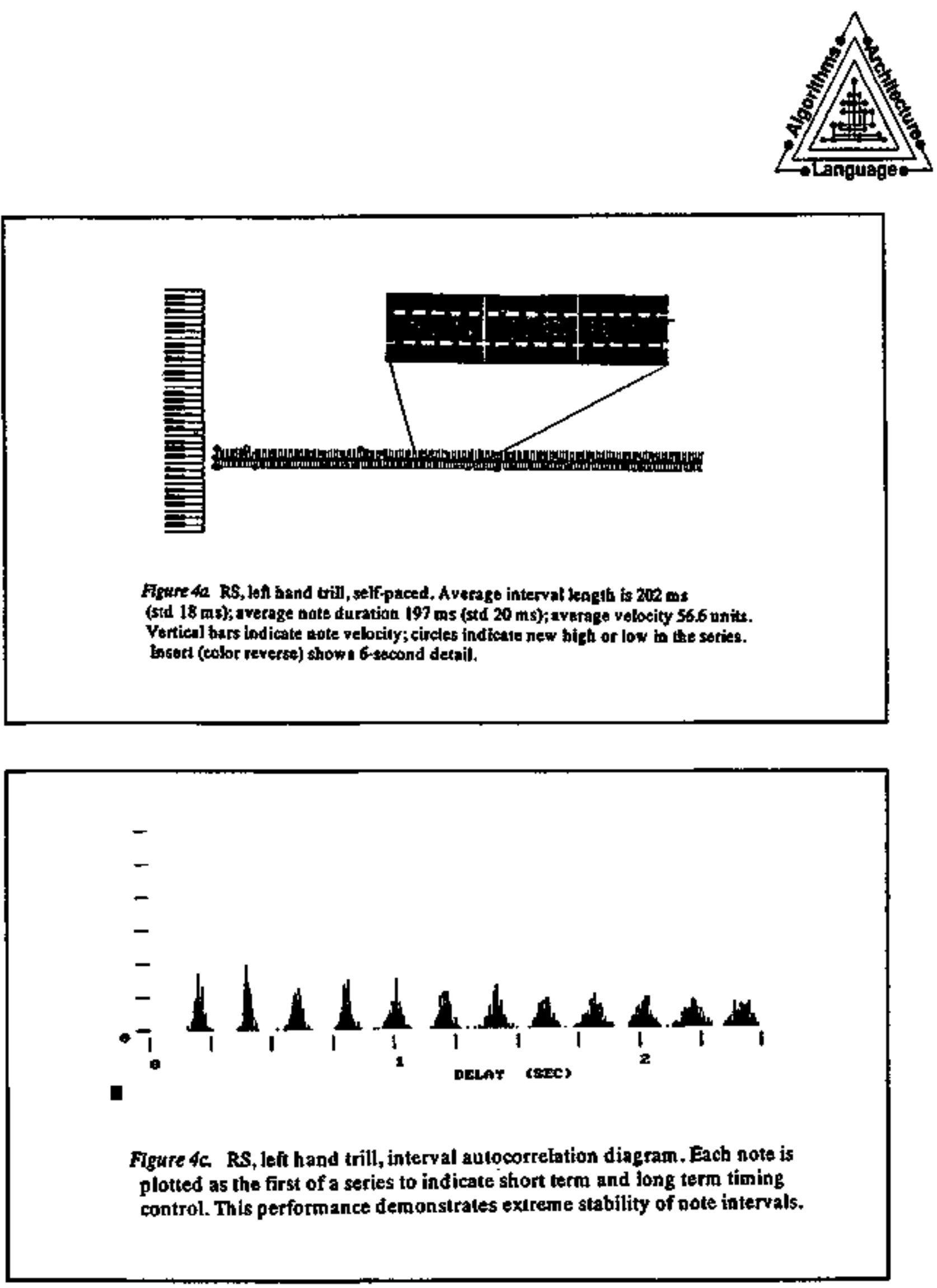

Figure 4c. RS, left hand trill, interval aulocorretation diagram. Each note is plotted as the first of a series to indicate short term and long term timing control. This performance demonstrates exireme stability of note intervals. 

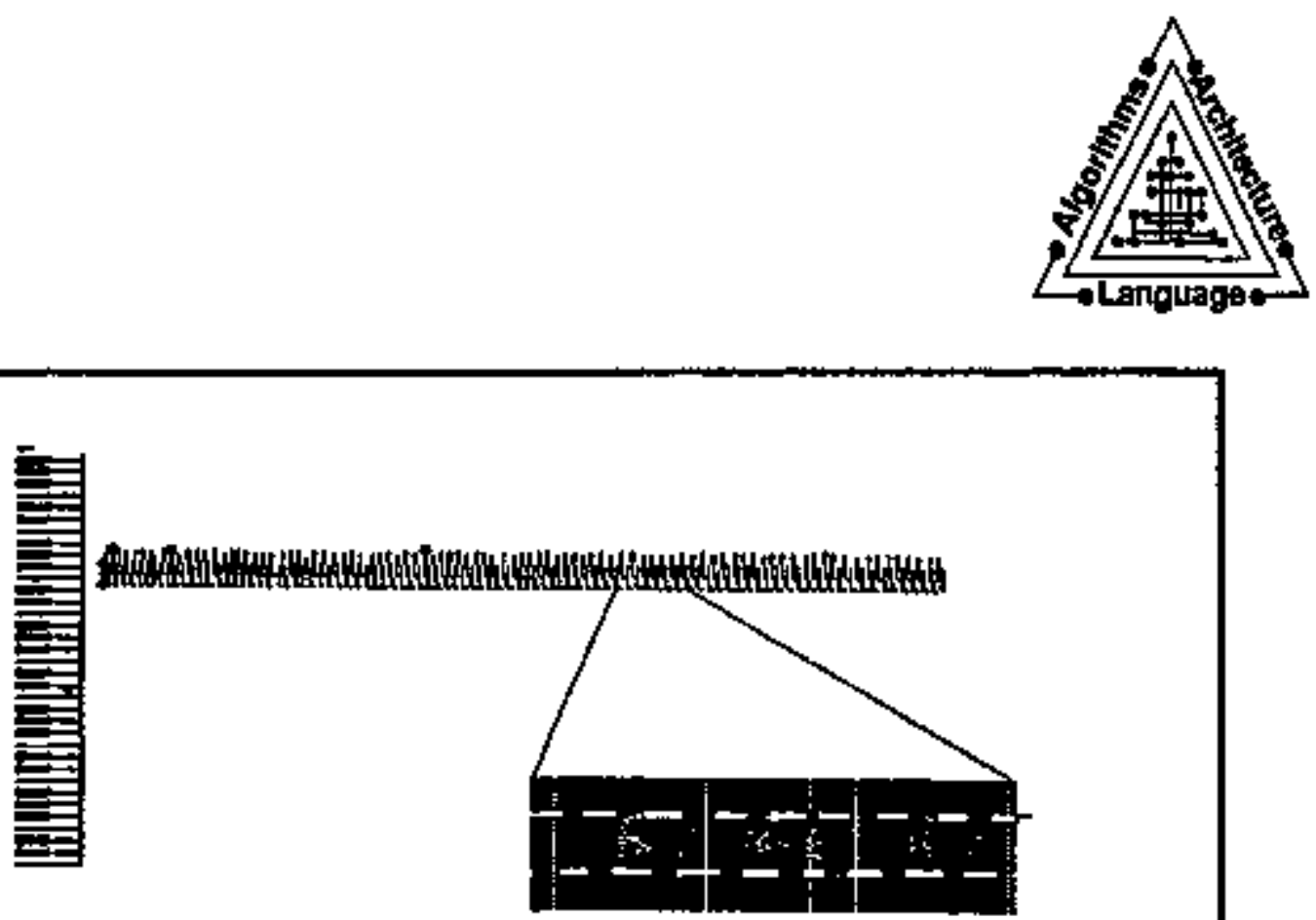

Figure st. RS, tight hatd trill, self-p sced. Average interrat length $15344 \mathrm{~m}$ (Atd $\mathrm{A4ms}$ ); avarage durolion is 385 ms (std 90mot); averege velotily is 66.93 units (atd 351 inies). Verticat bers, cisdes as in Figure 43. Insert (color reverse) thon s 6-secosd detall.

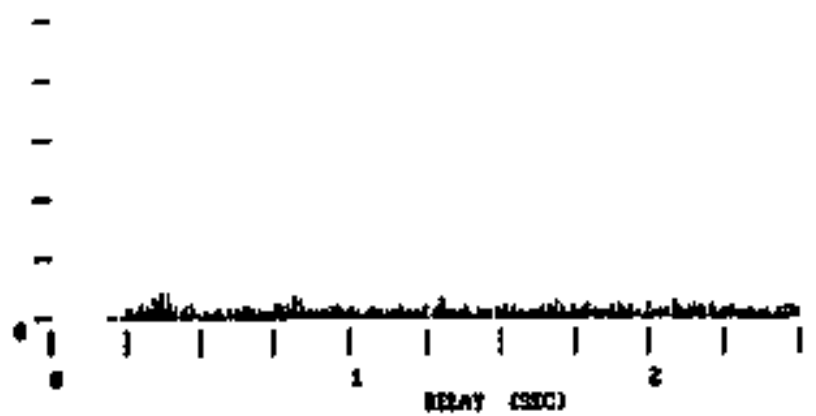

Figure Sc. RS, right hand trill interval antocorrelation diagram. Compare with figures $4 c, 6 \mathrm{c}$. Analysis shows no evidence of note-to-note thythic preciston. 


\section{THE HIGH PERFORMANCE STORAGE SYSTEM \\ Dick Watson, LLNL}

The Kuhn and S-Curve Paradigm Shift Models HPSS

- Kuhn's unodel

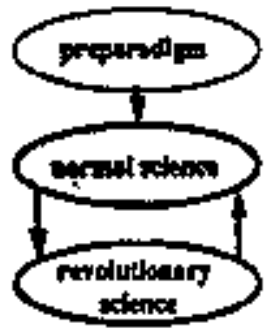

- The S-curve model

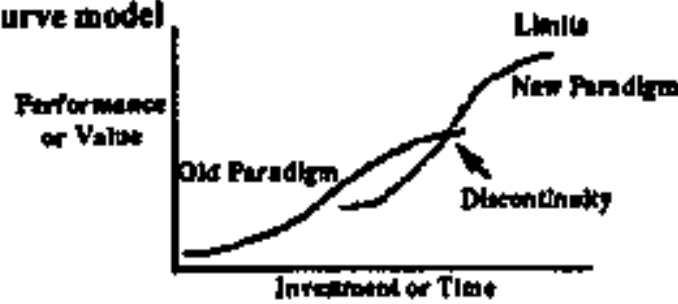

Challenges Driving the Storage Syslem

Architecture Paradigm Shifts

\section{HPSS}

- Mosing and storing terabyte datesets genernted by scienlific and commercial applicalions and experimental date collectioo derices.

- Acbieving to and query latency batanced with advances th processing and memory stress

- Effectively utiliting hiph pertortnance atworks und aetworkcontrected storage devices.

- Integrating scalable, parailef storage and scalable poralled computing system5.

- Integrating large scale dato management and hiterarcbical storage systems.

- Integrating distributed storage tavironments.

- Proriding toore effective system management services for the iacreasingly complex dlstributed storage enviroatsents. 

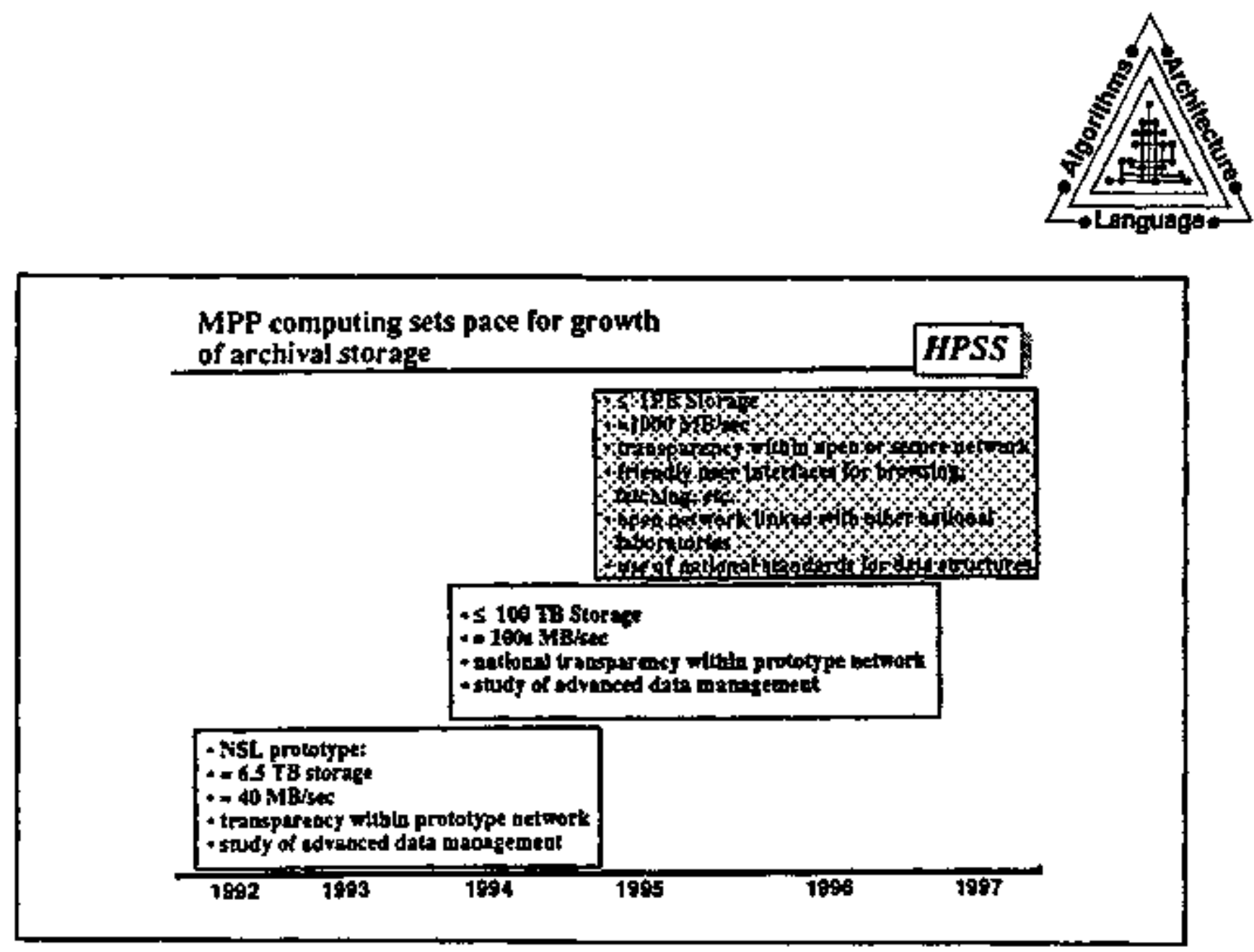

Enabling Applications

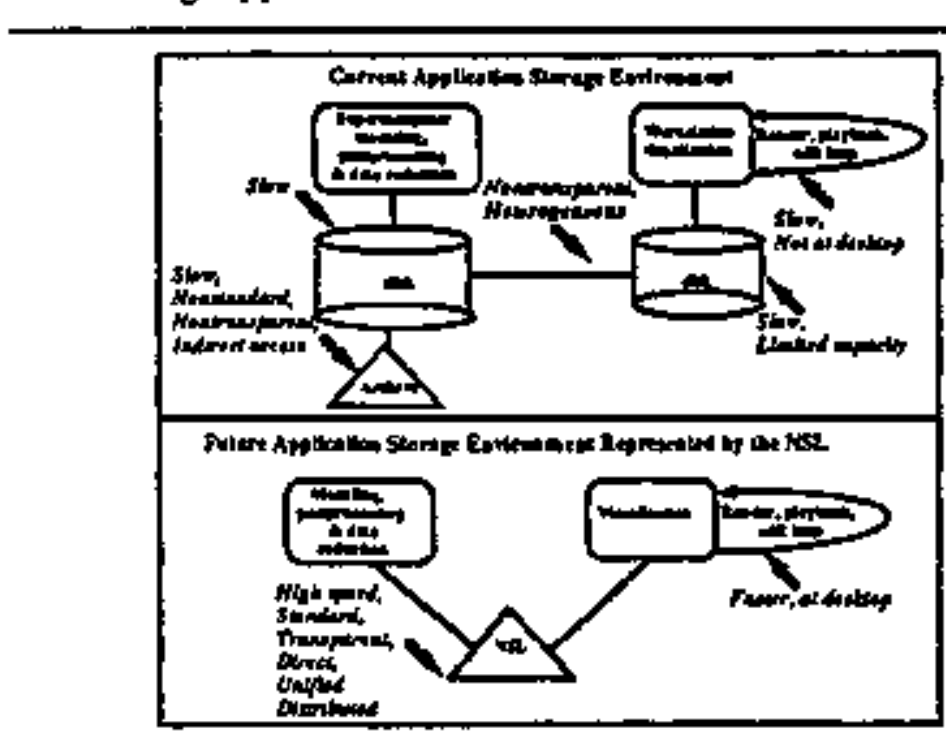

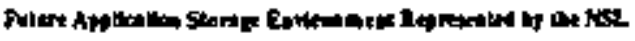

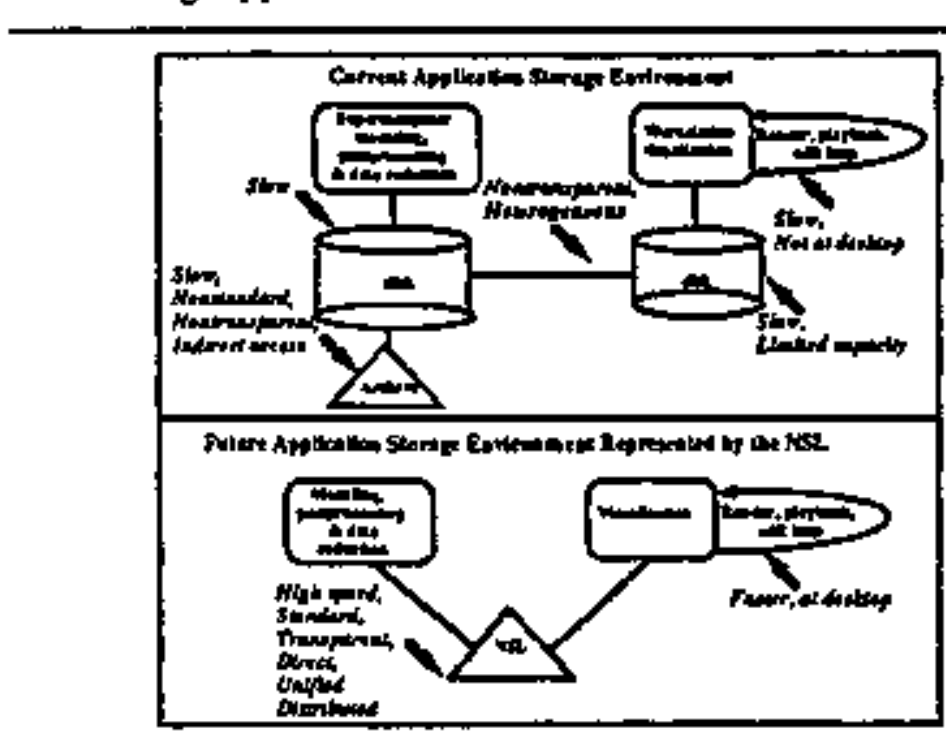

HPSS 


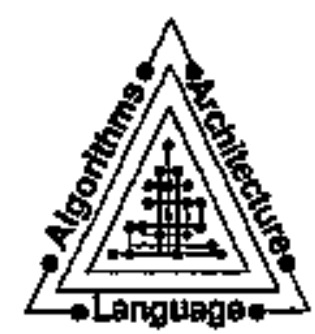

NSL A Growing DOE Laboratory, Industry, University Collaboration

Orlolan: Industry CRABA Members IB: Federal

THM SSD

Ampex

OpenVletas

Network Systhms Corp.

Mordenm Strated

2uled

Nem Industry Fantktpupta

Cray Resianch

Intei

CFI

IGM

Kbestr

Psiteeh

DEC (pendion)

Kendal Squart Research (pending)

Melko (pending)

Labordory and Goverament Members

LANL

LLNL

ORNL

SNL

ANt.

SDSC

Corbelt Information Technolongies

Cortall Theory Center

NASA-LERC

National Storage Laboratory (NSL) Objectives

\section{HPSS}

- Tecbnical

- Tested, eviluated, demonstrated general purpose bigh performance, distrlinuled, bierarchical storage arcbitectures.

- Development and demanstration of negr storage systew functionality.

- Commercíalization

- Demonstrated, tested, evaluated integrated hardware and sortware products from multiple vendors.

- Conmercial avilability of the testbed hardware and softrare.

- Influence on and testing of slorage system standards. 


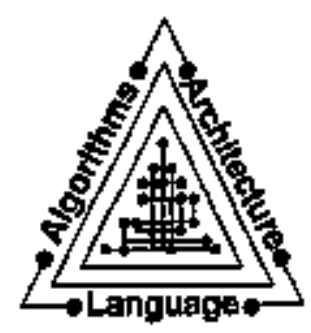

The Challenge of Achieving Balanced VO Archilectures -

The Limits of Mainframe Channel Connecled Slorage

HPSS

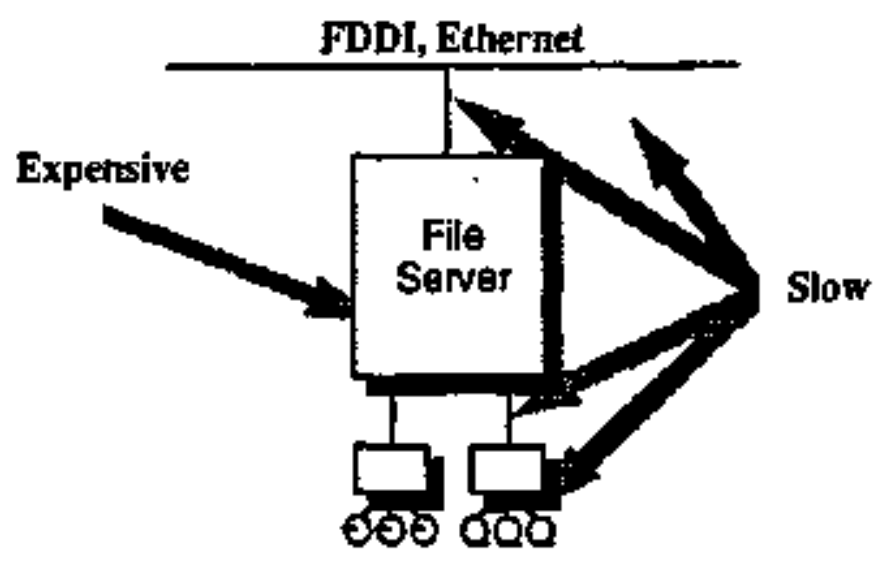

Archilectural Overview of

the National Siorage Laboratory

HPSS

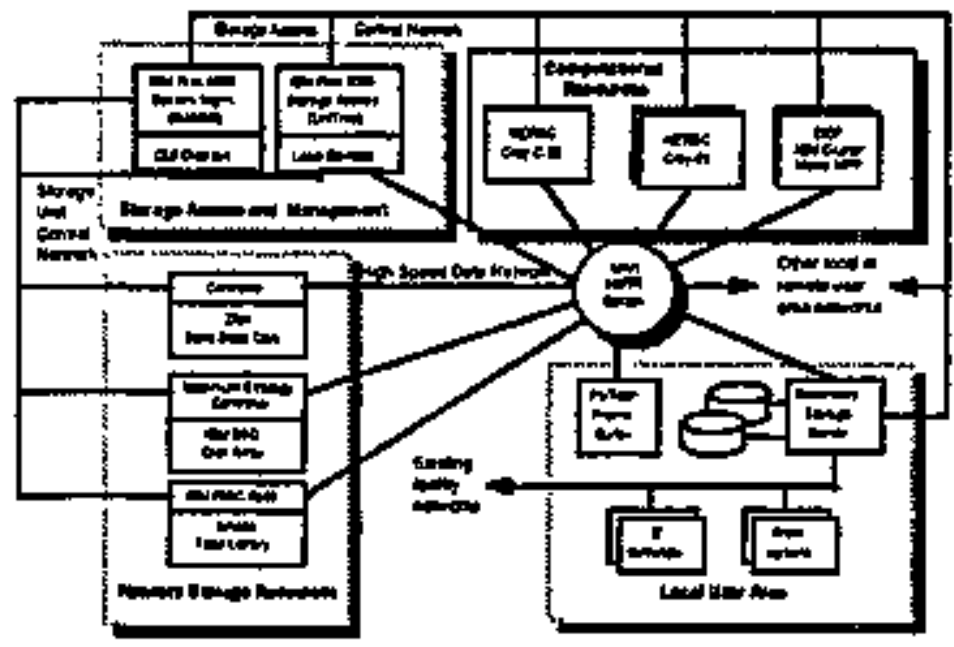



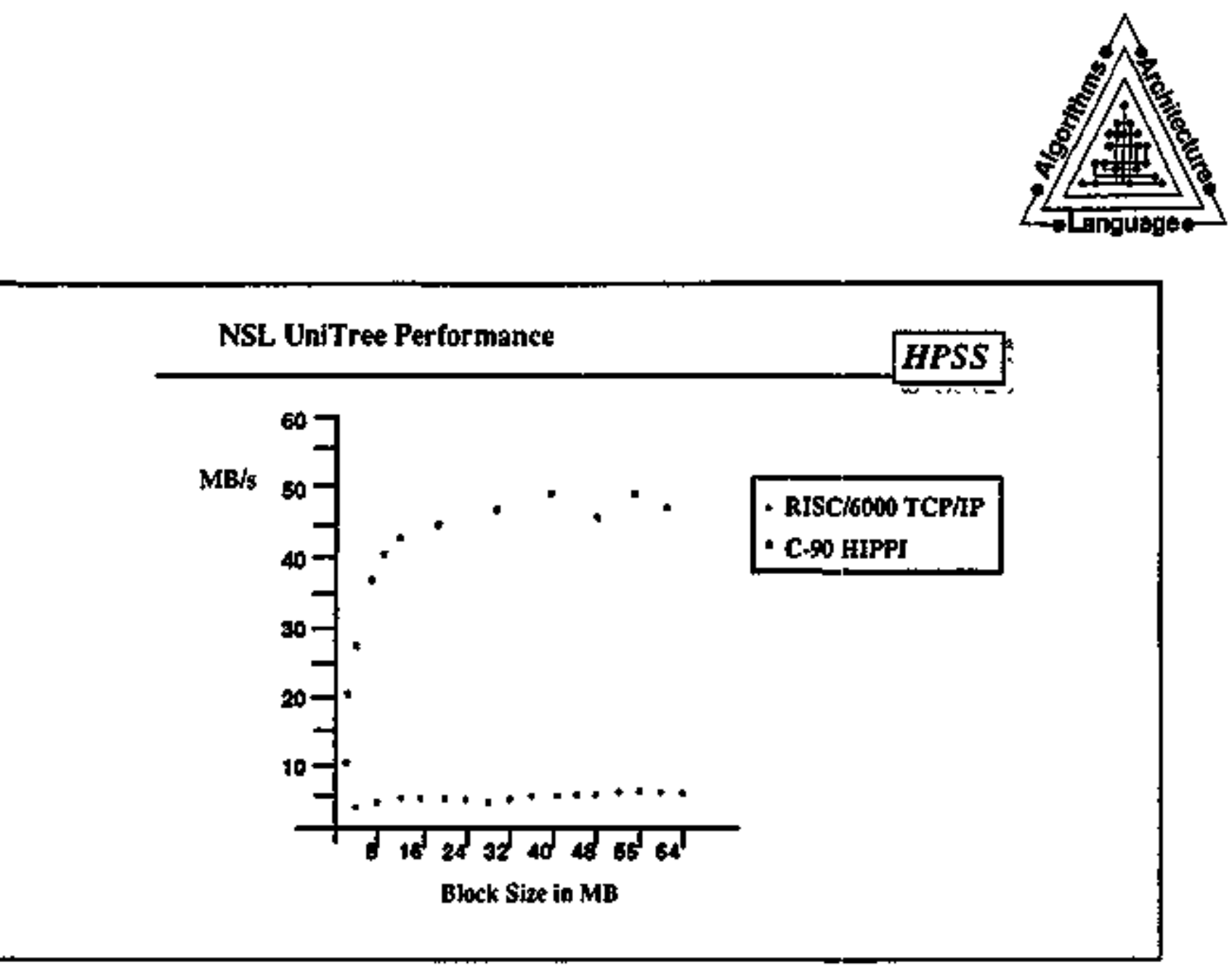

The Challenge of Archiving Scalable Parallel VO: the Extended Data Layout Problems

\section{HPSS}

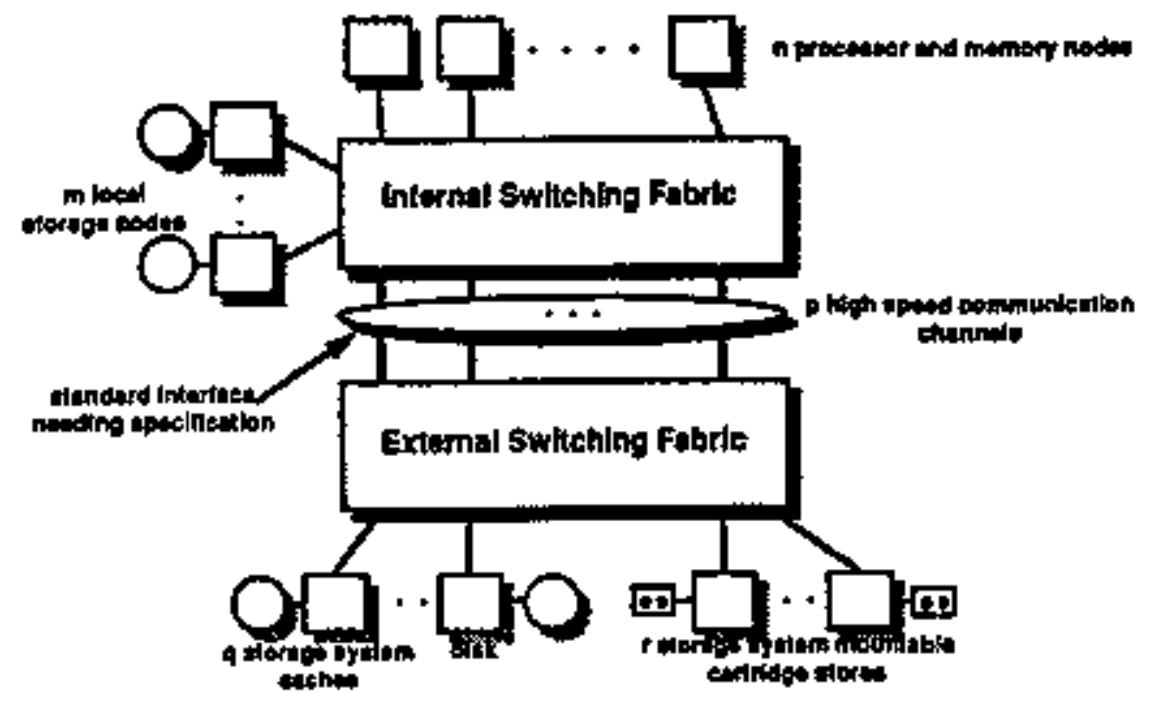




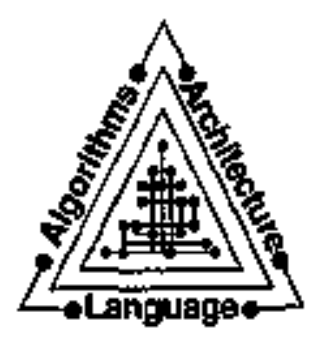

An Example: The Configuration that the NSL High

Performance Storage System (HPSS) Win Support

HPSS

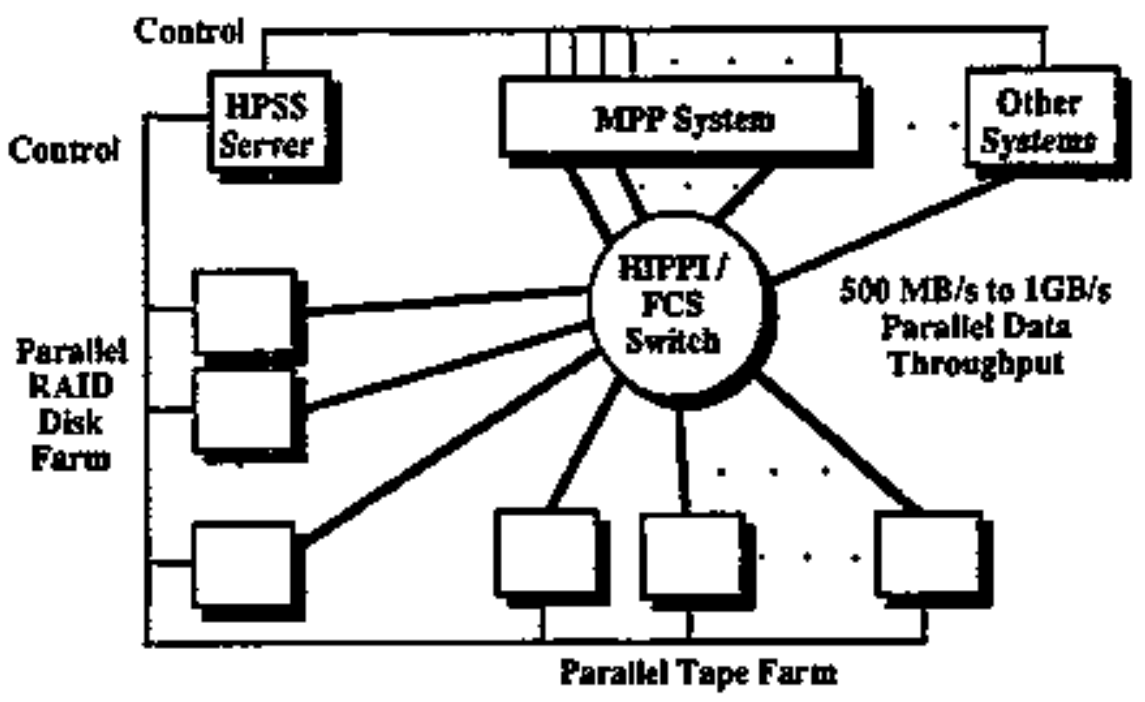

Characteristics of HPSS

HPSS

- Focus an sealability and MPP integration

- Ability to add hardware to suppost striping acroes devices and VO chanuels.

- Servers designed for multitasking and uultiprocessiog.

- Abiliny to distribate servers.

- Petabyte store, contrining billians of files, allihons of directories.

- Scalabite data transter to GB/s range.

- Interlaces to support lotegration with large scole data nabagemeot systems.

- Support for a wide range of storage devices and multiple slorage bierarchies. 


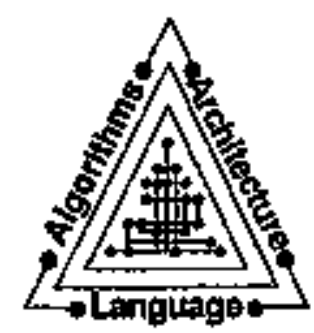

Characteristics of HPSS (continued)

- Support for standard incerfaces, NFS, AFS, DFS, FTP. HPSS

- Excensive GUI based storage system mapagement services.

- Security built in from the initial design,

- Portability to moltiple vendurs platforms.

- No terual modintutions

- Bull on OSF's DCE infrastructure, implemented fn C POSIX compalible.

- Layered archittecture hased on IEEE Mass Storage System Refereuce Model: Versions.

- Bult using components from moltiple verdors.

- Migratios pall frow NSL.UatTres.

- Projected 3 yesr developtnent investment > \$10M.

- Reliability and recoverabitity features (e s, Transactiop managemetat, system and File metadata on separate mediz and multiple copies)

\section{HPSS Architecture}

\section{HPSS}

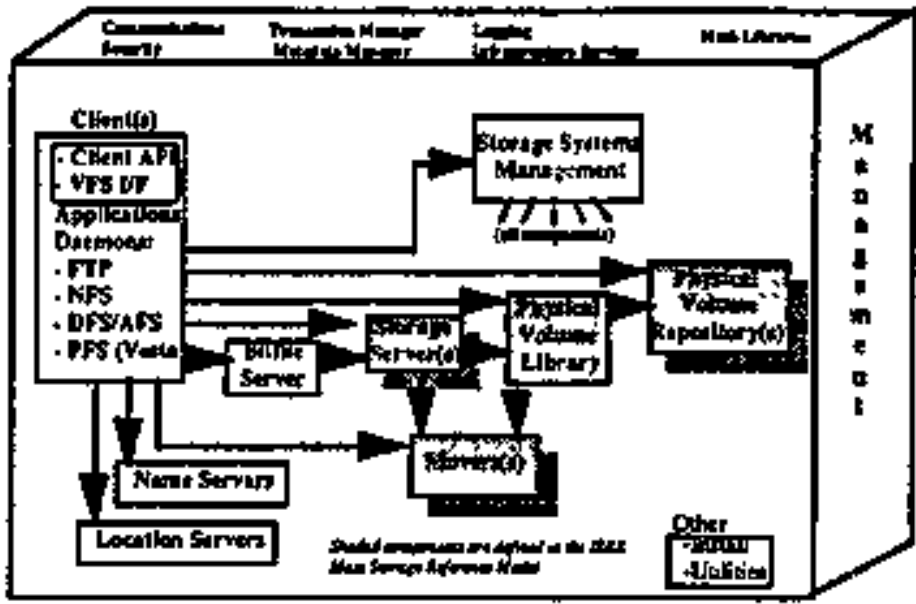



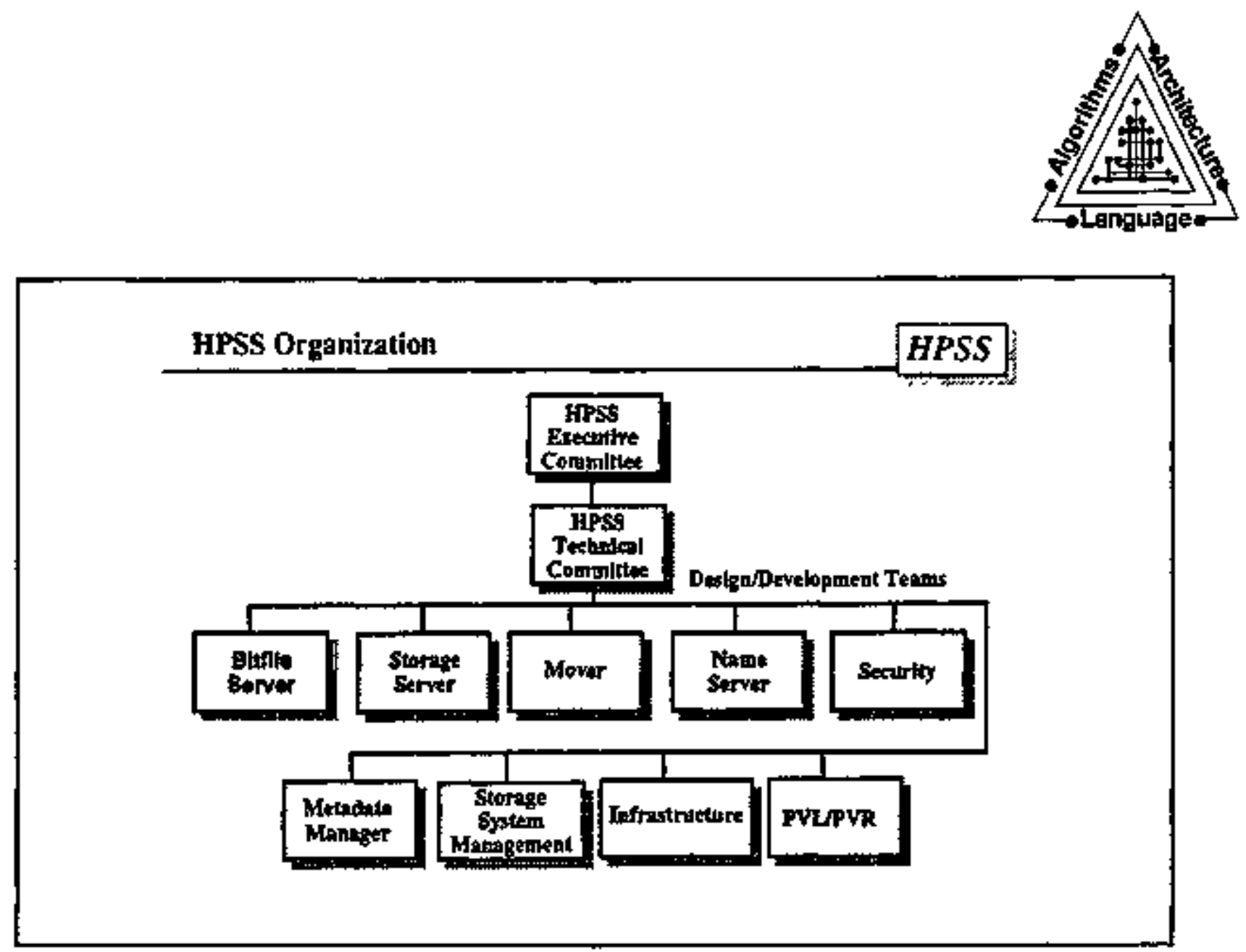

Layered Access to Storage System Services HPSS

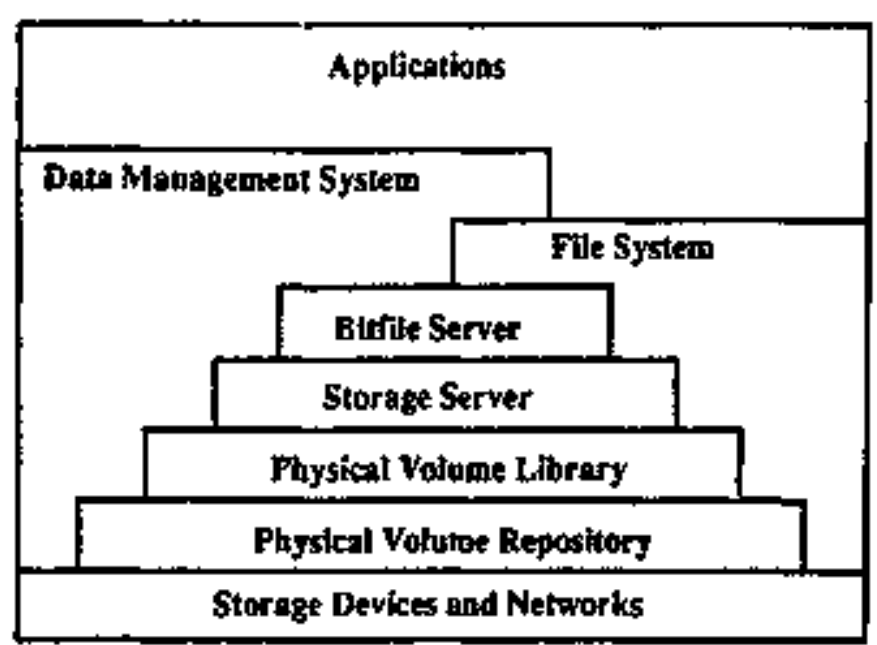




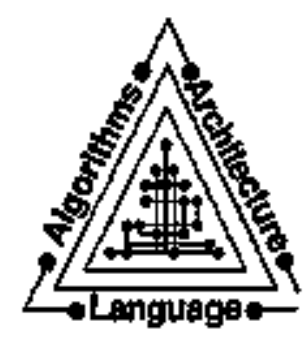

The Challenge of Integrating Large Scale Data Storage and Large Scale Dala Management HPSS

- Problen: Users dob't think of their data In terms of files or clasters of fles, but rather is applination,oriealed absitractions (e.B. climate conditions in spatial and temporal terms).

- Appronches

- Subsetting of the data based at predicated or observed query behavior and storage systetr characteristics

- Abstracts or compresion

- Query time predietion

- Storing appropriately or ganized tretadata

- Controd by tbe date management systeti of clustered data kyoul (e.c, volume and arder)

- Access by the data manarenent system to the approprite storage layers and absiractions

Example of Desirable HPSS and DFS Integration HPSS

Global DFS Name Space

Hegh Performance Demolns

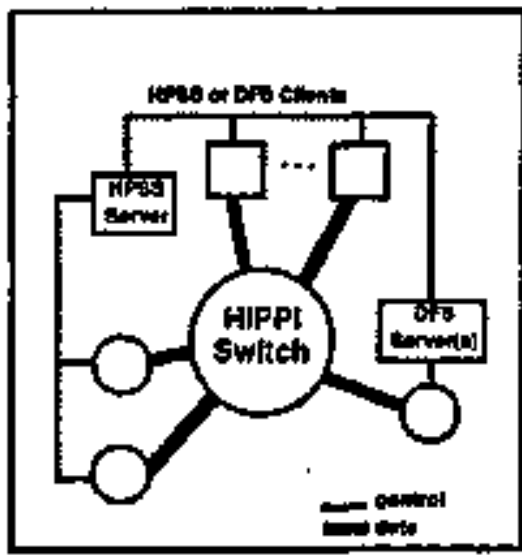

"Ordiagr" DFS Domalss

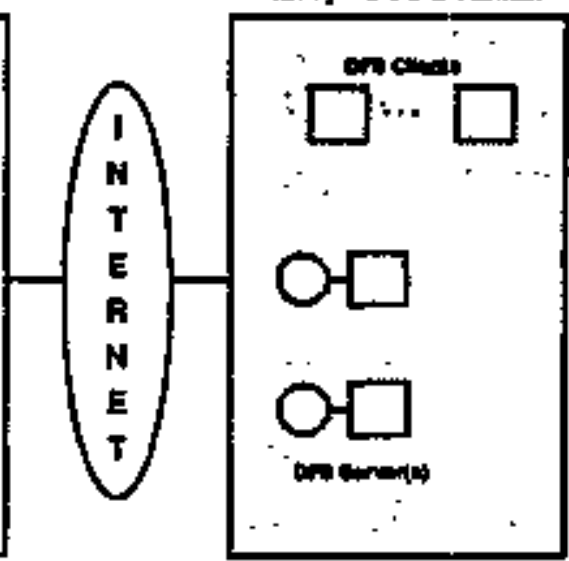




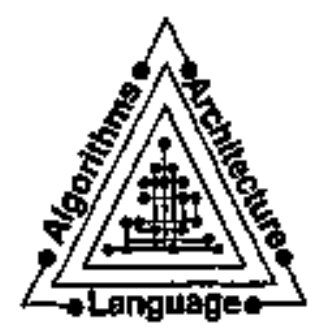

Dynamic Storage Hierarchies at the National Slorage Laboratory

\section{HPSS}

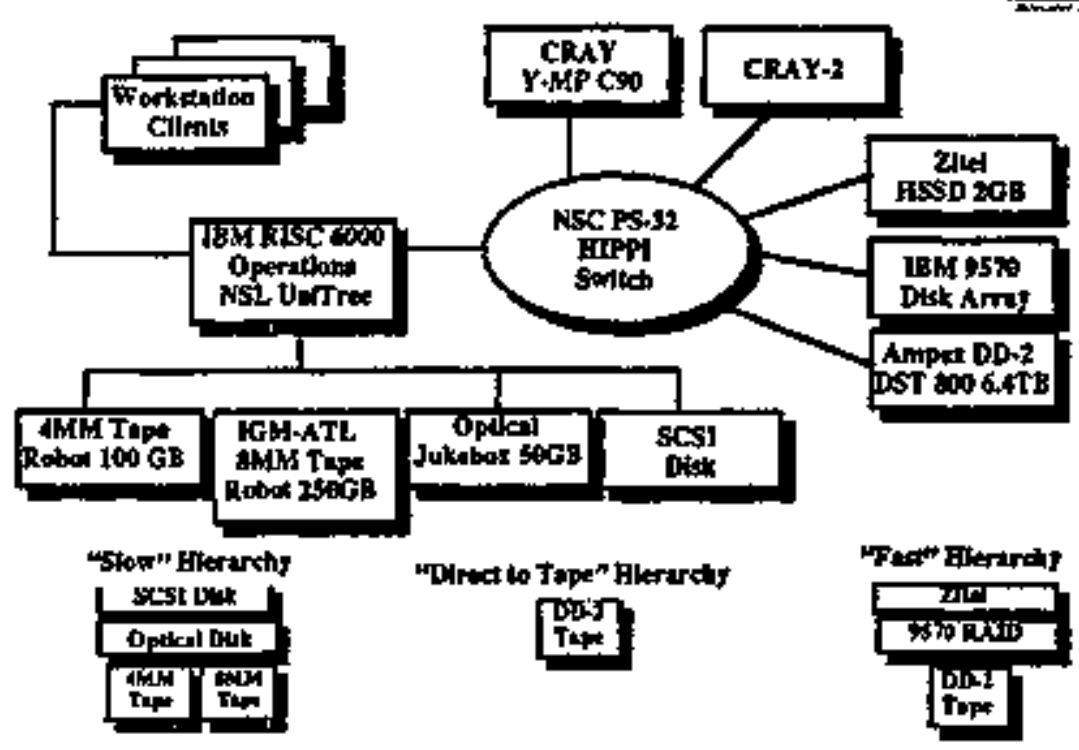

Generat Physical Model

- A transfer is between two file systeras.

- Deta is distributed over a set of subsystems

- $\left[S S_{s} 1,2,3\right\}$ is a set of sending subsystems

- $\quad$ SS 1,2,$\}$ is a set of recelving subsystemg

- Data is moved between subsystems 


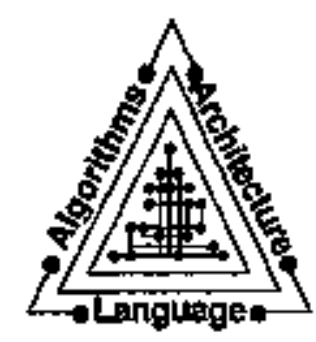

Conceptuat paralle! now

all bytes flow in parallel from sender to receiver

HPSS

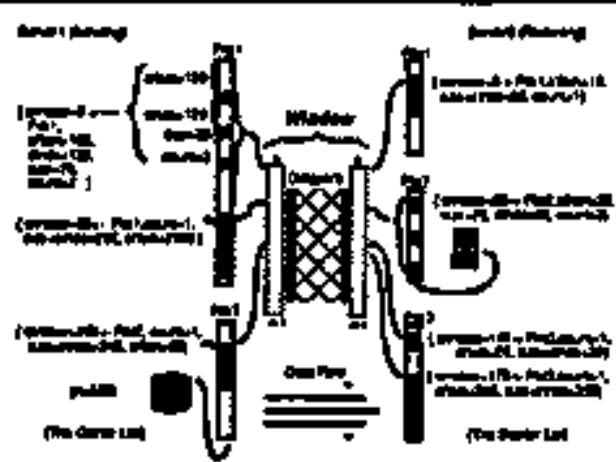

- objest la sender seat to objects í recelvar

- a guther list for sender, a scatter bst for receiver

- list of sender and receiver defioss a window

- there will be many mappings involved

- Data nows from sender through window la rectever

\section{Dała Allocation and Storage Management Detalls}

HPSS

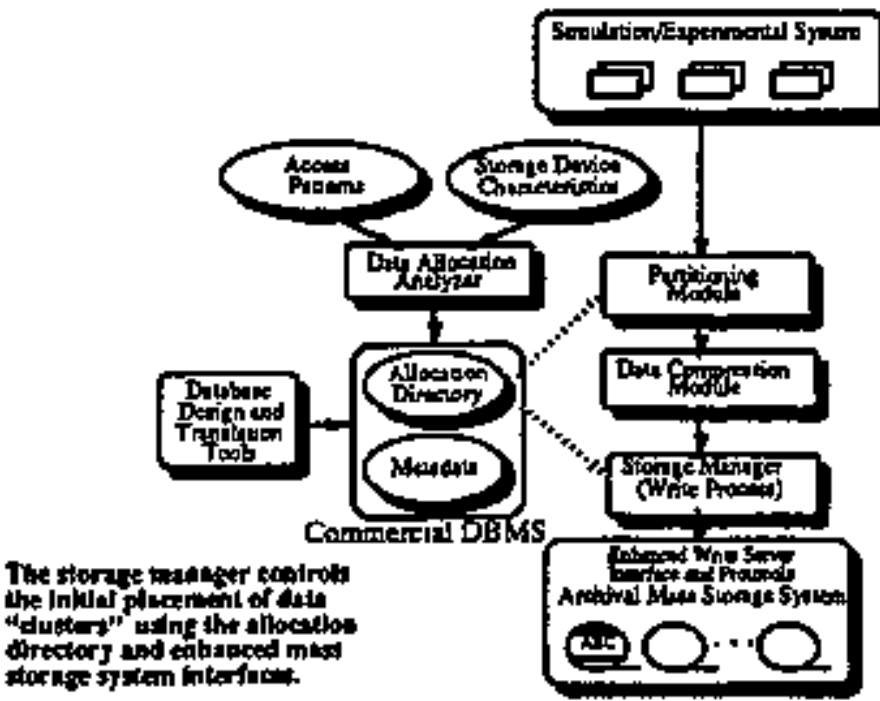




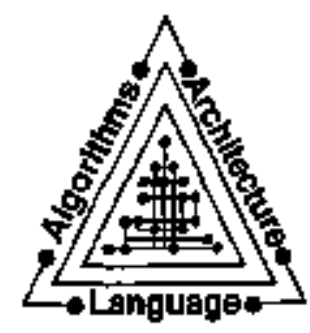

The Challenges Requiring Improved System Management

\section{HPSS}

- Evolving distributed, multiple dyoamic biererthies tnviroements.

- Need for iutegrated, standards-based system manapement tramewark.

- Need for mort and more automation and better GUI bosed mook

- Ablity to mange systems in constant evolution over years.

Parallel Transport Refleclor HPSS

- WoodenMan proposal

- will be sent to Refector Partcipants

- To get on Rellector.

- Emall ta pio_requesteperscipov

- Give your email address

- Give your postal address

- Give your instlutlon

- To Pariticipale io design review

- Emad to pla@nersc.gov 


\section{QUANTUM COMPUTERS \\ AND FREDKIN GATES}

Isaec Chuang, Stanford University

\section{Introduction}

Why do computers dissipate energy? The amazing fact is that in principle, an idal computer does not necessarily have to dissipate any energy at all in order to function properly. This conclusion is recent; before, it was widely belketed that computation necessatily entailed dissigation of $k T$ in 2 joules per elementary logic operation, actording to the 1949 anaiysts of von Neumann. But in 1973, Bensett showed that for each logically irreversible Turing machine a reversible one could be constructed, fn principle. Around the same time, Fredkin also developed his idea of a revertible logic gate. These demonstrated that in principle, a computer could be built which dissipates regligible enetgy.

Tociay, it is believed that a perfectly reversible computer may be constructed in principle, but susceptibility to noise would probably render it nfeless for practical purposes. Nevertheless, we have leareed several fundamental facts about the selationship belween energy disslpation and computing.

First, we now realize that energy dissipation is solely a matter of convenience. Dissipating energy allows us to operate a tinlte sized computer reliably in the presence of noise, and finish our calculatjon in a finite amount of time.

Second, we bave come to understand better what "dissipation" means. Landauer"в conjecture is that dissijoation occurs only when information is lost, and vice versa,

Finally, it is believed that through the study of ideal reveroible logic gates, we msy come to understand better the physics of complex goantum systems and guantum measurement, the sobject of much controversy throughout the past half century.

Physics and computing have always bad a deap relationsbip. In particular, the stody of reversibie computers brings us to what is perhaps the most intimate connection between the two disciplines, as demonstrated by these three observations.

'Tbi worl wa sopporied by a Fanie and John Berts Faondation Fellowship. 


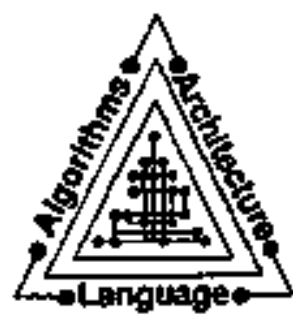

Today, I would Hike to present for you a review of the ftatus of this field, and a summary of my on-going research in this area. What $]$ will not tell you is that reversble computing is the wave of the future; it is not. What I will tell you. is the following message. The study of reversible computing will help to answer these questlons:

- How moch enesgy must be dissipated in practical situctions. to perform arbitrary calculations? What are the fondapental physical limits?

- What ksves are fmportant in reducing energy consumption (beyond obvious technological limitations)?

- What technokgies may be exploited to better investigate complex [quantum] systems?

This last item may be of particular interest to those who are investigating semiconductor logic devices of fength scales smaller than a tenth-micron. because in that regime, quantummechanital effects start to berome important. It is also a fascinatiag area for exploration in its own right, from the viewpoint of fundamental physics.

The outline of my presentation is as follows. I will begin with a brief description of the history of reversible cormputing, staring from Landaver's exorcism of Maxwell's demon. This background will provide a basis for the explanation of my research goals and approach. The utitizate application of my results will be in the area of minimal enetgy computing, which has already benefited from the technology of reversible logic. Finally, I address some open questions in the field by presenting early results from my research.

\section{History of Reversible Computing}

The original motitation for the study of the thermodynamics of computing was the desire to develop a thorough understanding of the inability of Naxwell's dernon to violate the second jaw of thermodynamics. As you may recall, Xaxwell's demon is an imagipary beikg that was deliberately contructed by Jame Clerk Maxwell in 1875 to violate the second law of thermodyaanics. He envisioned a mintature demon which could extract ezergy out of a gas cyisider initlanly at equilibrlum by separating the fast and slow molecules into the two halves of the cylinder.

[ Figure showing Maxwell's demon ]

Whether such a beast is porsible or not eventualiy boiled down to the question of what information tbe demon could extract from the system it was observing. It was realized that by performing a measureanent on each gas molecule it sax. to determine fis velocity, the demon could indeed ceparate the gas into hot and cold molecules on either side. Howeter. as Landautr noted in 1962 , to do this, after ach mescurement the demon is required to resel its internal state. so as to forget the resules of its previous measurement. This act of erasing information 


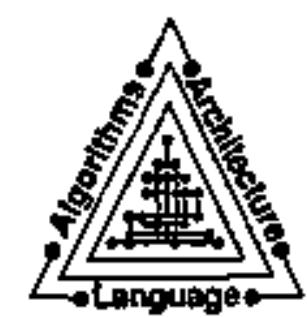

increases the demon's entropy by preiseig the some amostat taken asocy from the ges moleculos in the cylinder.

This key reafrzation, that information erasure corresponds to an mirease in entropy, is known as Landaver's conjecture. More colkogujally, we may say that foformation loss leads inevitebly to energy dissipation.

Drring this period, electronic computers and quantum-merhanics were both introdnced. Also, in 1948, Shannon laid the basis for the scipnce of information thery. First to andyze the analyze the energy dissipation of a computer was von Neumann, who estlmated that on the average, $k T$ ln 2 Joules must be disspated "per elementary act of information, that is per elementary decision of a two-wsy alternative and per elementary transmittal of one unit of information." What ja most interesting is that for elementery boolean logic gates, von Nenmann's ansuer coinciles exactly with that expected from Landauer's conjectnje. This to made obvious by noting, for example, that the AND, OR, and XOR operations are logically irreversible; they correspond to mathematically non-invertible operations.

[ Figure showing logic gates, info lost, and energy dissipated ]

Until 1973 , it was thereiore videly bejieved that any computer would unavoidably dissjpate $k T$ ln 2 Joules per gate on average. However, Bennett[1] then realized that nontripial computa. tion may be accomplished without use of logically irreverrible operations. He proved that any Irreversible Toring machine may be cast into a reversible one by adding the appropriate bookkeeping information. Around the came time, Fredkin|2] also came up witi a logically reversible ptimitive which is boolean complete. This gate, known as the Fredisio gate, has thre inputs and three outputs, and the following truth table (Figure 1).

\begin{tabular}{|ccc|ccc|}
\hline \hline \multicolumn{3}{|c|}{ Inputs } & \multicolumn{3}{c|}{ Outpuis } \\
\hline$A$ & $B$ & $C$ & $A^{\prime}$ & $B^{\prime}$ & $C^{\prime}$ \\
\hline 0 & 0 & 0 & 0 & 0 & 0 \\
0 & 0 & 1 & 0 & 0 & 1 \\
0 & 1 & 0 & 0 & 1 & 0 \\
0 & 1 & 1 & 1 & 0 & 1 \\
1 & 0 & 0 & 1 & 0 & 0 \\
1 & 0 & 1 & 0 & 1 & 1 \\
1 & 1 & 0 & 1 & 1 & 0 \\
1 & 1 & 1 & 1 & 1 & 1 \\
\hline \hline
\end{tabular}

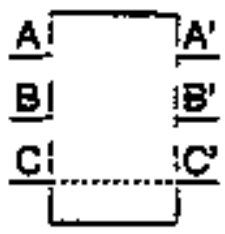

Figure 1: Fredikin gate sehematic symbol and truth table.

This gate is particularly interesting, and I fhall shortly retum to discuss its properties in detail. In 1982, Fredkin and Tofiot introduced a concrete physical model for a reversible computer, based on collisions between billiard balle and appropriately placed mintors. The fascinsting

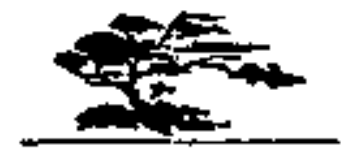




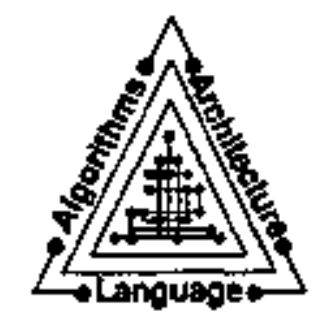

thing about this madel is that it is mantfesily reversible. insofar as its operation is based on the laws of classical mechanies.

[ Figure showing Interaction Gate]

The billiard ball model of computation is known as a "ballistic" computer because it depends on perfect operation, and the absence of external perturbations such as those caused by thermal noise. In contrast, Bennett introduced the notion of a "Brownian" computer[3], which depende on the agitation caused by therral notse to propel a computation forward.

Findlly, since 1982. there has begn sígnificant progress in extending the zealm of reversible computing to the quantum domain: Benioffi4]. Deutsch[5], and Feynman[6] have proposed teveral foms of a quaptum-mechanical copputer, whose operation depepds principally on the Hamiltonian evolution of a state vector. I shall return to this stbject later.

The central conclusion reached by researchers in this field thus far is that reversible, disstpationless corcputers are certajnly possible in theory. although in practice. energy dissipation will certainly be required for system stability and apise immunity. We aiso now understand a key principle - reversibility sterns from keeping tracl of every bit of information in a computer. 


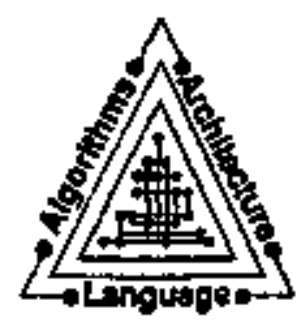

1875 Maxwel's demos introduced.

1949 Von Neamentestimated that KT ln2 (3E-21 Jonles) most be dissipated aper elementary oft of information, that is per elemestary decision of a two way alternative and per elementary transmittal of one unit of information."

1929-1962 Maxwell's demon is excotised.

1961 Holl Landwer attempted to prove von Neumann's answer. But be found only that Infically irreverrible operations generate a local tocteas in the entropy eqval to the information thrown sway.

1973 Bennett tealized that noatrivial computation may be sconmplished without use of lobitally itreveralble operations.

1982 Fredkin pablished his reversible logic gate primitive, and showed that is is boolesn complete. Fredkin and Teffoli aleo devired a madel of computation based on the tollition of "billard balls." This was the first model of a ballitic compoter.

1982 Benrett introduced his "Brownlan computers" which deperd on thermal noise to agitate a machine toward completion of a compotation. In tonttast to the ballietic models, thermal noise is an integral part of the compotational process; in fact, the baflistic compater cen only function properiy in the complete abeence of thermal noive.

1982-1986 Study of quantum-mechanical rewatible computers by Beniof, Feynman, Zutek, Dentech, Landaner, otc.

\section{Overview of My Research}

Now I would like to introduce my own teseatch. I have been perenally interested in reversible computere sinte I was an undergraduate at MIT. My education has actully been in quaturn field theory and computes architecture, whlle semiconductor device physics is something I have been learning only sinte coming to Stanford two years ago. My discustion will be oriented towards fundumental phyaics and syctem insues, but I will be bappy to entertain anestions or comments from a different perspective as well.

\subsection{Goal}

The concept whtch Intereste me is a telation govarning computation which has been hinted at In the iterature, bat bever explored quantitatively - pamely, that there exist; some tradeoff 


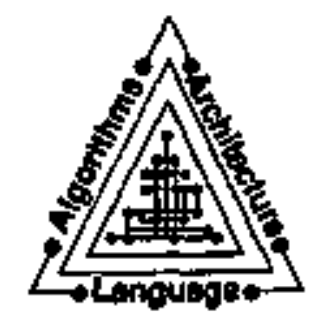

between time, energy, and reliabitity. This rejation has been expressed as the co-calied "Spreng Thiangle $[7]$, shown here.

[ Figure stowing Spreng Triangle]

The three verticks on this triangle represeat the tiree extremes of tero time, energy, and informatios, while the three edges correspond to maximal information, tine, wod anergy. Spreng phillosoptically noted that it is the atarving phtwosopher who seeks the least costly soletions by acquiting maximal isformation, while the primitive savage is content to expead as much energy as is geded to colve the problew, and mpders wan is conterned primarily with a quick fix.

I sm motivated in this study by oxr carrant understanding of some of the postble fimits. For example, we know for a fact that given infinite time, we can pesform an arbitrary calcolation to a sperified reliability, with zero energy. Specifically, Bennett has ahown that the required enezgy dissipation per step can approsch zero as long as a reversible computer is operated adiabatically. However, this is not so interesting in practice, ln reality, the central issue is how to do wome useful computation with a fanite size machine. at finite temperature, in a finite amount of tlme. Given these constraints, bow unch energy must we disspate to perform the calculation, and how fast may each logical step be performed, at best? The altimate goal of my study is to antwer these questions.

\subsection{Approach}

My approasch towards understanding the fondomental physical inits to computation is besed on two effotts - first, the construction of a new mathematical theory for describing the quantum. mechanical embodiment of the simplest ideal physica! logic gate. and becond, the actual experimantal implemantation of a simple carcede of retsible logic gates in a mososcopic cyotem.

Developinent of a quantum theory for reversible computing begias with the description of the purest physical model for the elementary buliding block of the ideal computer. Cascading ideal logic gates into a complex cystem will then give a model which may be otudied to ascertain the performance achievable under specific non-ideal conditions. stutb as in the presence of thermal noter. Finally, by coupling each ideal logic gate to nowse reservoirs, the amount of disaipation required to stabibze the behavior of the cystem m*y ba dotermined.

Experimental taplementation of an ideal logic gate is an ambjtions goal. The principal problem is that an ideal lopic gate is a closed system with few degrees of treatom, and that is hatd to actieve in practice. This area of researth represents work in progress for me. My grovp at Stanford University bpeciatizat in the stady of noise in masoscopic systems. We wit be exploriag the physics of two-dimensional electron gases in the GaAo/AlGaAB material system at temperatures bejow 20 millikelvin, using a dilution refigerator. My thesis wavisor and group leader ts Professor Yoshibise Yamamoto, who is well-known for establtshing the field of sqneezed light Bemicondurtor laser diodes. Ous torrent idea for fabriczting a Fredkin gate involves poskibly adapting a version of Kouwenboves's singte-electron turnstile device. 


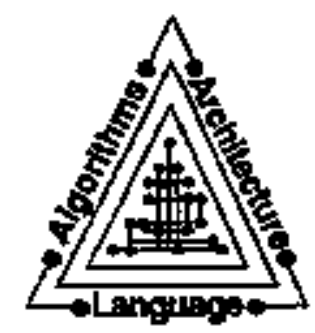

[ Forre of logie gats cuade and Kouwaphoven's tornetile]

\section{Applications of reversible logic}

Before contineing with to derctiption of my own resenreb, I will now describe in greater detall what revattible logic is, and how it may be applied in practice.

\section{I Conservative invertible logic}

What is a Fredicin gate? There are miny ioserpretetione of this device. Considar once apain its troth table. The most important characteristion of 1te transfer finction are that 1 . the

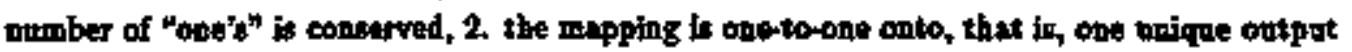
exists for anch inpat and vice verso. These properties, the existence of an additive congerved quantity, and the invertibility of the transform, are the basis for describisis the Freilfm Gate as a couserntive invertibje lojic gate.

\begin{tabular}{|ccc|ccc|}
\hline \multicolumn{3}{|c|}{ Eguts } & \multicolumn{3}{c|}{ Outprs } \\
\hline$A$ & $B$ & $C$ & $A^{\prime}$ & $B^{5}$ & $C^{\prime}$ \\
\hline 0 & 0 & 0 & 0 & 0 & 0 \\
0 & 0 & 1 & 0 & 0 & 1 \\
0 & 1 & 0 & 0 & 1 & 0 \\
1 & 0 & 0 & 1 & 0 & 0 \\
0 & 1 & 1 & 1 & 0 & 1 \\
1 & 1 & 0 & 1 & 1 & 0 \\
1 & 0 & 1 & 0 & 1 & 1 \\
1 & 1 & 1 & 1 & 1 & 1 \\
\hline
\end{tabular}

Figate 2: Truth table for a Fredtin gate clasiffed aecording to bit elaes (number of one's).

Why are the properties tpecial? As Frodlis asd Tofoli explato in their 1982 paper, these oymmetsies are mptivated by principles-fundamentid.to almont all plytical phenomers we anderstend. The comerved quantity is entor (for exumple), and lnvertibility corresponds to mierascopic revettibility.

The Frodkin gate is also apectal in that it is boolean complete and construetion aniversal. Since it may perform tither an AND of an Of function whes confienrod aptropriately, it ent be

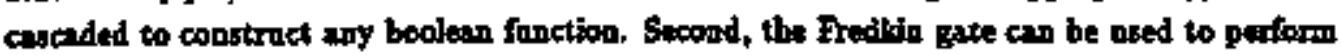
mosubver und straight-through routing, which wre the two routing fonctions recessary to allow cosstruction of arbitrary rontes through a ragular graph. That this property halds followi from 

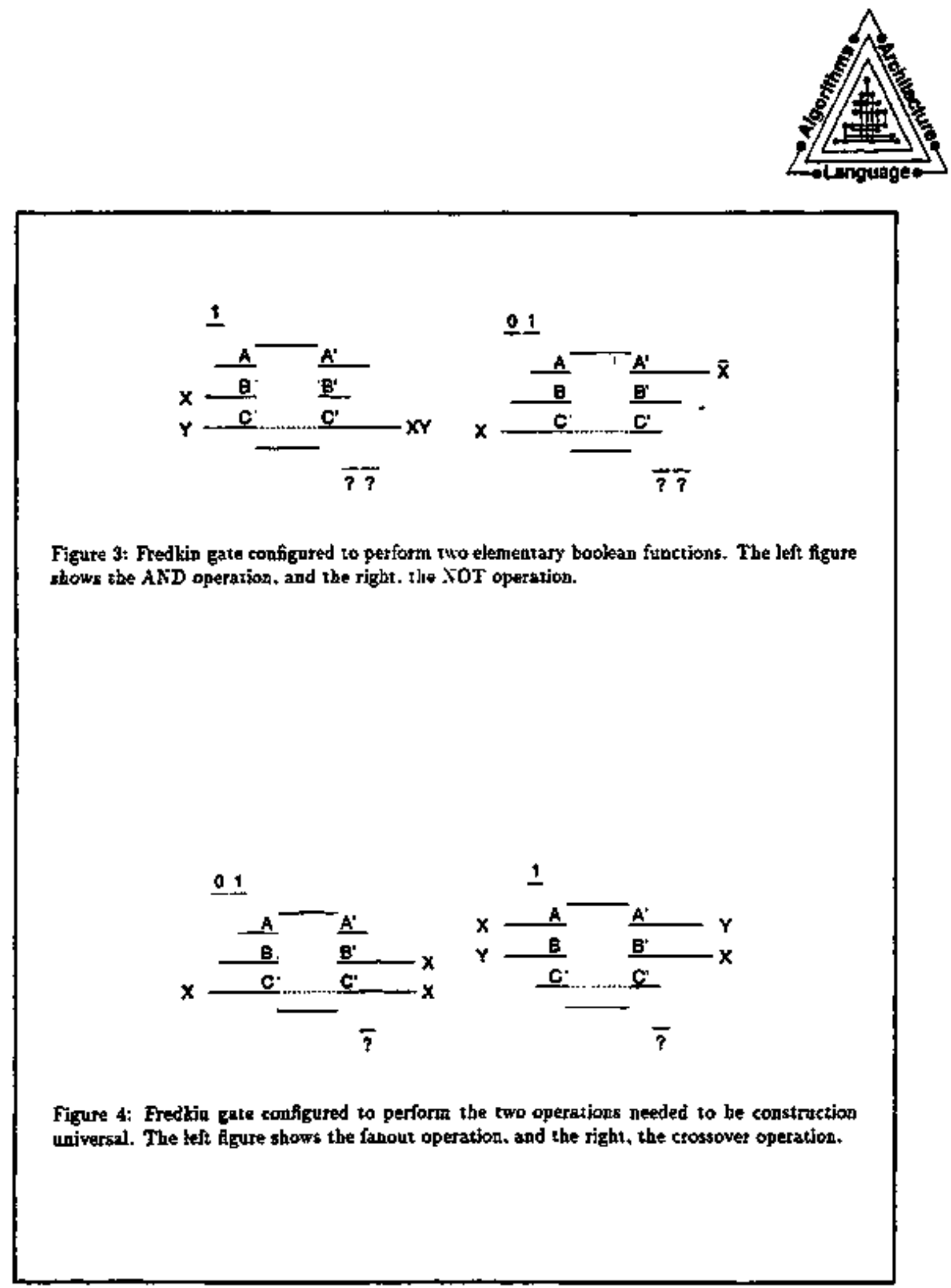


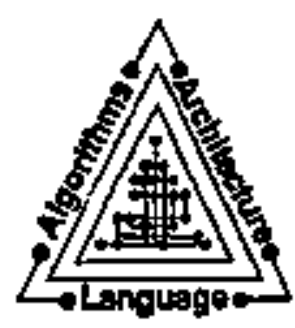

yet another fundamental physical principle - that duplication, i.e., fanoot, is anpatural, and is en operation that most be accorated for explicitly.

One more interpretstion or the Fredlin gate truth table exists. Mathomutically, it in useful to view a conservatlve invertible logic gate as a data-dependent growp transformation operaclon. For the threeport Fredikin gate, by dassilying the inputs by number of "one's, we see that the transformation applied to get the proper output it just a simple permintation, with the particular permutation which is performed being a function of the number of "one' $\mathrm{s}$." In this case, all bit-classes are trassformed identically except for the two-bit case for which these two entrles are permoted.

\subsection{Applicatione of CI logic}

Conservative invertible logic cas be osed to reduce ouergy consumption in two ways. First. energy can be kaved by constructing computational syetems from CI logic primitives stech as the Fredkin gate. This allows unused "oce $\mathrm{s}^{\mathrm{s}}$ to be reycled, thus lowering the anount of energy dissipated. However, achieving logical severtibility will never lower energy dissipation beyond the inherent imperfection of the physical devices used. Thus, the next step is to replace diefipative logic devices (such as MOSFETB) with chargo-recover devicts, then eventually with ballistic devices, such as Milburn's quantom optical Fredłein gate.

[ Figure - "ilteducing Energy Dissipation with Cl Logic" ]

The first step is estentlally one of software technology. We know that it is always posible to embed a ingically irreversible caltulation into a logically reversible one. As Benzett and Fredlin have khown, and as stond be obvious from the boolexn completenese of the Fredkin gate, in irreversible function may be calculated reversibly and tepeatedly by performing the calcolation nsing auxiliary etorase, copying the desired result, then performing the reverse ealculation to restore the ctorage to jes initial state.

[ Figure - Bennett's reversing computer \& HPP kerned]

The problem of how mueh axtitiary storage is seqnited is known as the "garbage collection" problem in reversible computing. However, I believe that thls problem is not fundamentad. One fundamental attraction of using conservatlve invertlble logic les in the notion that since physical phenomeda are mietoscopically reversible, it is ressonable that revertible microceopic agotithps for acentrically simulatiog them should also exist. Therefore, CI logic would form natural primitives for implementing, either in bardware of in cofitware, such simulations. The canclusion is that if problems are formulated properly, dealing with Earbage khorld not be 2 problem.

One immediate technological ppobibility utilizing CI logic is a minimakenergy programmable logic aray. The device jtself tould be fabricated with CMOS transistors, and opetated with a reversible power supply, it couid possibly dissipate asymptotically zero power as a function of eloek freatency. Of cource, the dificulty is in the optimal soduction of the application 


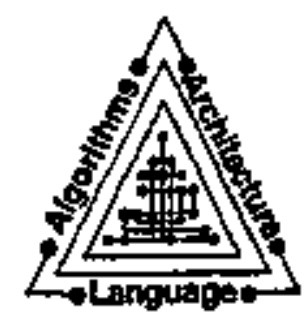

program 10 CI logic prifitives. This mathematical problem is similat in dificuty to that of normal boolean reduction, but research bas showed that certain simpliffications may arfice from inherent symmetrie due to the properties of Cl logic. In fact, teduction into Cl logic primitives is an interesting problem ts its own right; fecently, it has ben shown that the collision ternel for hydrodynamic lattice gas simulations. which is normally implewented as a lookup table, may be simplified signtifcantly when implemented using Cl logic priantivin in an application-specific IC.

A fascinating concrete example is Barton's 1978 implementation of a subset of the PDP-10 processor vsing conser vative logic. Shown here is a diagram of his basic machine structure, taken from his peper. There is a randor accoss memory M, a reck memory P, 24-bit instruction I, 24-bit accumulator AC, and gathage stack G. Several fateresting things may be noted from his study; first, most instructions may actually be implentented in s reversible manner. The oply isseversible functions provided were AND. OR. LOAD. CLARAC HSH, LSH, and ABS, and it is not cleas that those instructions necessarlily had to be irreversible (except as a matter of convenience). Other insights gaived were that it is necessary for a subroutine to bave osly a single veturn point. since the patb of execution must be retraceable. Also, each memory operation hto to be a read/writei con-destructive reads were not possible.

[ Fagure diagram of Barton's PDP]

\subsection{Physical implementations of the Fredkin Gate}

I now turn to the description of the physical devices used to implement conservative invertible logic gates such as the Fredkin gate. There are two lindo of Fredkin gates, the "quantum" Fredkin gate, and the "demon" Fredkin gate. The difference is that the quastum ane is to a very good approximation, a perfectly closed system. while the demon gate is a collection of dissipative gates (snch as a MOSFET) emulating the logical operation of a Fredkin gate. Behaviofally, they afe also distioguished by their rodse properties. The demon gate. becange it is constrocted from frrevarsible primitives, is manifestly stable. but it may gever be dissipationles, no matter how perfect the device is. Examples of some proposed demon Fredkin gates are listed here.

Demon Fredkja Gates

- Likharev: Josepbsos Junction, Int J. Theor. Fhys. 21, S1s (1988)

- Canlfield: Liquid Crystal Modulator, Applied Optics 28, 2js9 (1989)

- Merkie: Reversible Charge Transfer. Nenotechnology 1. At (1998)

On the other band, the quantum Fredkin gate is the real thing. In the binit of perfect phyoinal implementation, the device is expected to operate in a dissipationless manzer. Becsubs of this, quantum coherence will persist between devices, and partition noise will arise. Another way to understand this effect is to consider it to be simply due to quantum interference. In fact, 


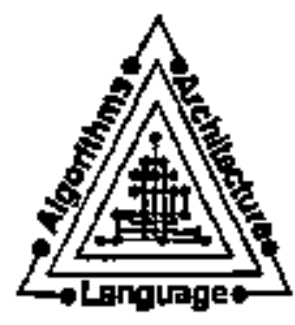

coherent effects are key to the operation of such devices. Several potential guantum Fredkin gate proposals are listed here. Note that no quastum Fredlin gate bas yet been experimentally demonstrated.

\section{Quantom Fredkin Gates}

- Milburn: Quantum Optical, Phys. Ren. Let. 62, 2J24 (J989)

- Ielam, Soccotich: Billiard-ball solitons, Optico Let. 16, 4990 (1995)

- Huanga Fiber Logic Sagnac, Applied Optics, to appear (1991)

- Lloyd: Pulsed Atrays, Science 261, Ja69 (1998)

\section{Open Questions}

The quantum Fredkin gate is perhaps the most Interestlng device to bave emerged from the study of reveroible computing. Investigation into the inberent nature of this device has connected the disclplines of computing, physies, and intormation theory, motiveting a wide variaty of opes questions. In this last part of my talk, 1 will describe some of the preliminary roults from my researeh on the quantmon Fredkin gate.

To recapitulate, my goal is to establish a quartilative relstion betwens fonciamentaliy inevitable dissipation and the rellability and speed of a computiag machlne. My approach in to devise a physical deseription of the elementary buibing blociss of a dissipationless machine, then to study the limits on its operation as external effects buch as thermal noise are introduced. To begin with, I note that the Fredlkin gate is an ideal guantum logic gate. In fact, I postnlate that the ptoper quantum deseription of any logic gate consists of to components, one being the Fredkin transform, and the other, a coupling to an extersal reservoir (corresponding to disoipation). By utudying this separation, I hope to voderstand why distipation sectons to be espentjal for system stabillty, even at the quartum irvel. Related to this is the understanding of quantum measurement, as a ciimple quantum Fredkin gate gedankenexperiment shows.

\subsection{The ideal quantum logic gate}

I begin with the following observation. The ideal computer is a reverelble one, and it may be constrteted from Fredkin gater. In fact, the simplest of the "jiteal" logic gates is the Frodtin gate, (or any of the equivalent conservative javertib) thres-port cotsins), since all bigher order conservative logic dates may be cinstructed by esscading fredlin gater. That no simpler reversible logic gate trists is proved by Fredin.

To eapture the phycical performasce limjts of an ideal logit gate, we nast tombody jta logical behavior in a physical system. Ope of the eimplest systers we may choose is the interaction of the harmonic oscillatarg described by the usnal puantum-mechanical picture with linear 


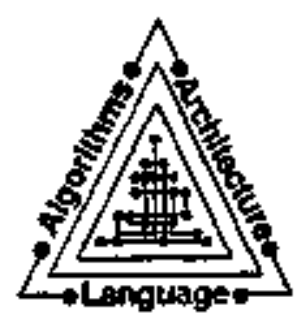

coupling. Although this theoretical model is quite simple, I will show that it indeed properly describes tbe expected perforriance of a real physical device, that of Milburn.

Let me begin by explaining the operation of Milburn's quantum optical Frodkto gate, thown here. The basic strocture oi the device is a Mach.Zehnder isterferometer, cosstructed from two 30/50 beamsplitters and two peffect reflectors. Because the path lengths of both arms are identical, the forcoming beams traval the came distance, then recombine; in the absante of any control signal, the ontgoing beanus are exactly the same as the incoming ones. When a control signal is present, howgver. the path length of the upper arm is increased, and the interferometer bacomes nnbalanced. The device is adjusted to opetate in 2 manner such that when a control sigral is present, the arms become nnbalanced by $180^{\circ}$, so chat the input signals are perfect]y switched to give the outputs.

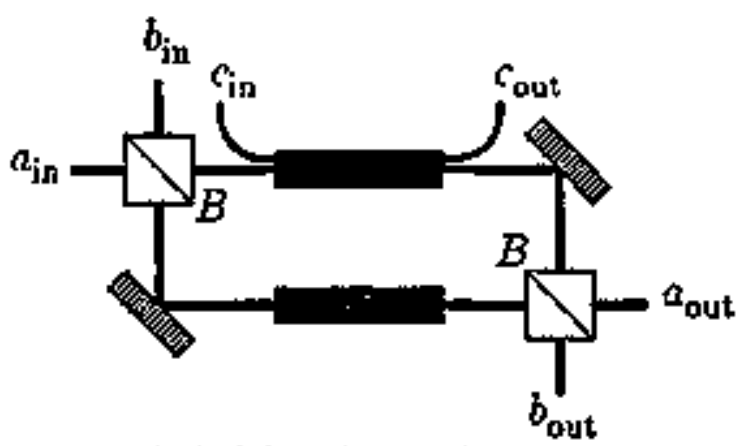

Figure 5: A prototypical Mach-Zehnder based Kers effect Fredkin Logic Gate.

The un-balencing occurs because of the physics of the -Kerr' medium; this is a $X^{3}$ nonlinear crystal whose index of jefraction is proportionel to the cotal electric fiefd intensity in the mediam. In other words, the more light going throngb a kert medium, the farter it trovels. Matbematically, we thy that the input states undergo sel and crosf-phase modulation; the phase of the light is changed by a function of the total number of photons present in the crystal when tho ligat beam passes through it.

[ Figare: kerr modium ]

Coming back to Milbuts's gate once uncte, the se that if we bave Schrobdinger picture operatore for the beamsplitter and the Kerr media, then we can write down a unitary transformation operator which describes the kegic gate. The logarithm of this transformation will then give us the Fredkin gate Hamiltonian. We proceed with this program by vsing the followiog operator description of a beamsplitter, as described by Yutike and others

$$
B=\exp \left[i \theta\left(a^{t} b+a b^{t}\right)\right] .
$$




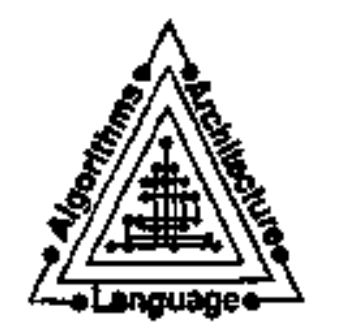

The key to thls description is that a beamsplitter can be seen as a SU(2) group cransfotmation apetator, which periontss a rotation in the space of its inputs, a and b.

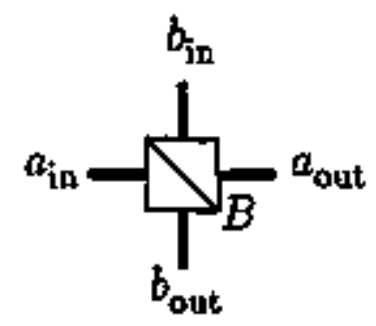

Figtre 6: Quantvm-mechanical Bearnoplitter

Fizally. putting all our mathematics togetber gives ts an operator description of Milburn's quantum optical Fredkin gate:

$$
\begin{aligned}
& \text { lout) }=\dot{\phi}_{6} \dot{\phi}_{c} B_{1} X B_{2} h B_{2} B_{1}(i n) \\
& =\exp \left[-i \gamma\left(n_{0}\left\{n_{a}-1\right)+n_{b}\left(n_{b}-1\right\}+n_{6}\left\{n_{c}-1\right)\right\}\right] \\
& \left.x \exp \left[-i x\left(2 n_{s} n_{2}+n_{e}\left(k_{a}+n_{5}\right)\right)\right] \exp \left[i x n_{c}\left(a^{\dagger} b+a b^{\dagger}\right)\right] \mid m\right)_{0}|\pi\rangle_{b}|p\rangle_{\sigma} .
\end{aligned}
$$

Here, the operator $\boldsymbol{H}^{*}$ is the Kerr medium transformation, while $B_{1}$ and $B_{2}$ are the beamsplitter transforans. For number-ngenstate inputs, the output is found to be this exprossion. The first two expopentials are simply irrelevan phase iransforms, correspondiag to self-phase modulation and cross-phase modulation. The third exponentisl is the real kasart of the logic operation. It is what we identify as the quantum Fredikin gate operator.

What does this exprestion mean? It is a contralled deamepitter. The effect of this operator is to periora a rotation in the SU(2) space of $a$ and $b$. by the angle $x n_{c}$. That is, the rotation angle is determined by the field strength of the control input. The canstant $x$ is an engineerimg paramelet deterfuined by the strength of the' Kerr media, and can be chosen so that when the control reaches the appropriatn strength, the logic gate is switched on; when ao control sigual is present, the gate is aatprally switched off.

\subsection{The Fredkin gate operator}

This operator exprossion for the quantum fredito gate is a significant sestlt. The logarithm of the Fredkin gate ttansform immedtately gives us the Hamiltonian

$$
H=\left(c^{t} c\left(a^{t} b+b^{t} a\right)\right. \text {. }
$$



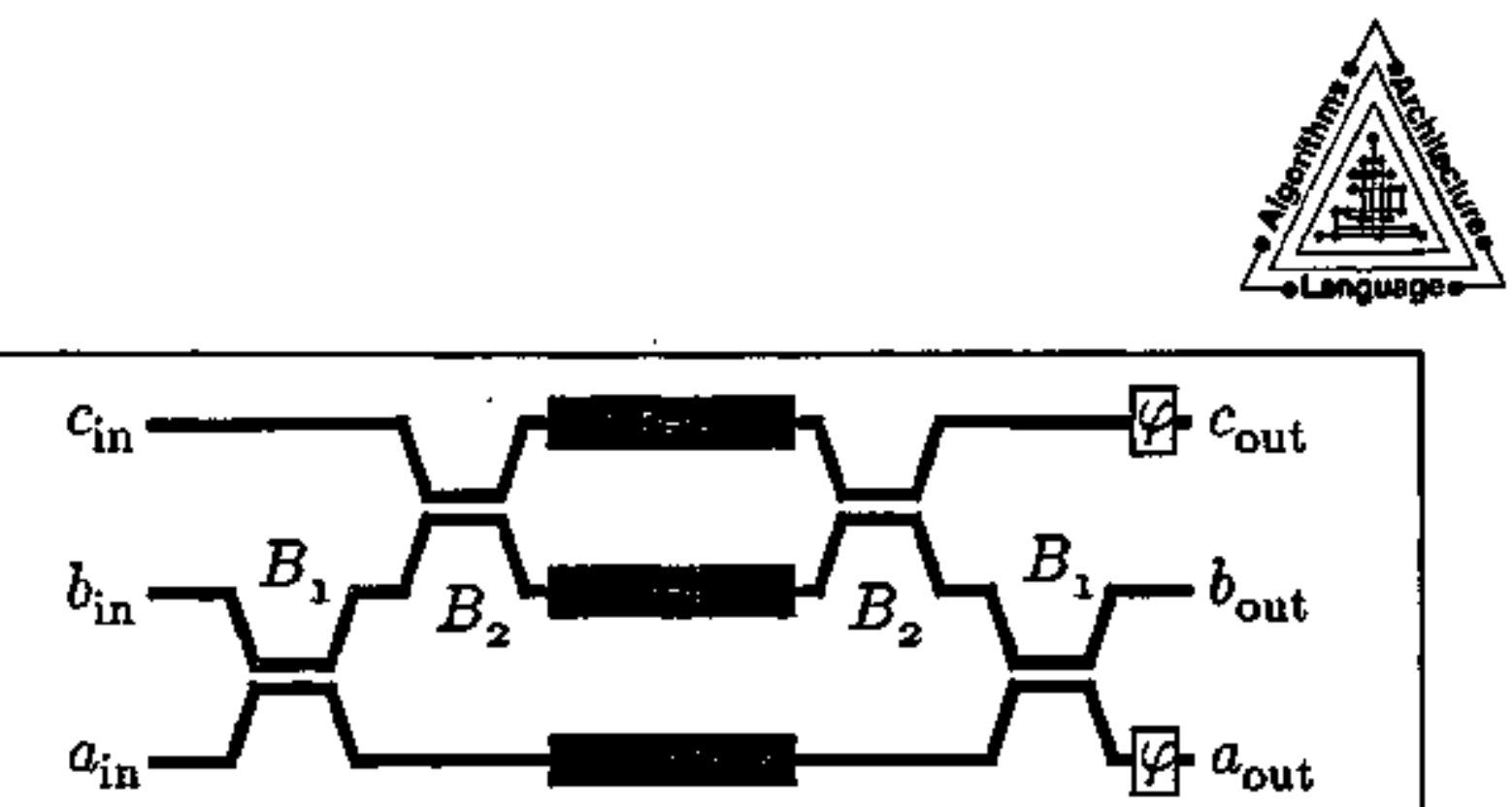

Figore 7: Threjpput Kerr medium axtension of the non-lisear Mach-Zehnder interferometer which works as a quantum-optical logic gate.

This is the Fredkin gate Hamiltonian, a beantiful concrete example of Dentsch's Hamiltonian[5]. It is, to my urderstandiag, the first complete Hamiltonian description of an actually physically realizable quantum Fredkin gate. The implication of this work is that since all conservative invertible logic gateg ate selated through as equivalence transform, therefore in fact all quantum Jogic gates may be described by the Fredkin gate Hamiltonian. The proof is the wame as that for the universality of the Fredkin gate.

Note that although the formalism presented hete was developed with boson operators, it generalizes inmediately to fermions. In tact, it has been stown by Kitayawa that closely located electron wavegtides allow electron cross-phase modnlation to occur; thv5, the nonllnear MachZebuder irterferometer strgeture poed for the quantum optical Fredikin gate could equally well be used for a balistic electron Fredion gate, in printiple (unfortunately, it is dificult to fabricate with presint technology).

The Harnititonian for non-jded logic gales will bave the came form of Do-id), but the coupling may be different. For example, a transiotor with dissipative eoures and drain, and $A$ ballietit gate, might be described by the Hamiltonjan

$$
H=\sum_{n} X_{n} e^{t} c\left(a^{t} b_{n}+b_{n}^{1} c\right) \text {. }
$$

The coupling hare titises on the form of a Caldeire-Leggett dissipative conpling to a rerwoir witb operators $b_{n}$. This expression, however, is stin tectative, and continues to be the cubject of active Investigation. 


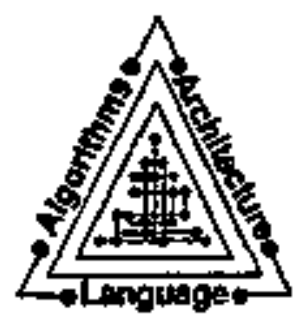

\subsection{Quantum measurement and the Fredkin gate}

My last sobject deals with the relation between quaninm measurement thoory and the quantwon Fredkic gate. The interesting question to ask is, what is the slmplest level at which one may ast an "if-ther" question? That is, for example, "if partiele $A$ bas moxentum $P$ thon eject as electron." Suck questions are naturally part of a logic gate's operation; phyaically, ench questions conrespond to performing a measurement, then acting on the result.

The key realization is that the "if-theo" experiment is not potsible if only two etats ate correlated; a thresody interaction is essential. It is simpls to sen that a two-body interaction is infufficient; for example, when the polarizatlons of two photons are cortelated with exch other then sent in opposite directions (this is the ptoton totn experincent), meacurement of ore photon conveyt no information about the other photon, even though it collapses the superpasition state athitrarily. No information is encoded into the original polarizations, and therefore superlaminal communication is impossible with photos twins.

On the other hand, if three photons are allowed to interact at the origin, then nontrivial information transfer seems to he possible. The following example is due $10 \mathrm{~J}$. Jacobsorn. We prepare the input states $A=|\hat{\rangle}\rangle_{t}, B=|0\rangle_{b}$, and $C=\left(\langle 0\rangle_{c}+|1\rangle_{e}\right) / \sqrt{2}$ and foed them into a

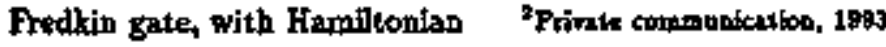

$$
B=\frac{\pi}{2} c^{\dagger} c\left[\alpha^{3} b+b^{\dagger} a\right\} \text {. }
$$

The output strate is

$$
\text { but }\rangle=\frac{1}{\sqrt{2}}[|011\rangle+|100\rangle],
$$

a macroscopic superposition state; measurement of the photon in ons of the three modes collapees the wavefunction, leaving the other two modes in a mixed state. Sily $A^{\prime}$ and $B^{\prime}$ (primes decote outpot variabies) are sent away to Antares, while the $C^{t}$ ontpust je kept locally. If $C^{t}$ is left unmessured, the detector at Antares findo $A^{\prime}$ and $B^{\prime}$ to be in a superposition tate, while on the other hand, if $C^{\prime}$ is measured. $A^{\prime}$ and $B^{\prime}$ are found to be in a mixed state. Thus, mersurement of $C^{\prime}$ would seen to chamge the statistics of $A^{t}$ and $B^{\prime}$, foster than the spoed of light.

At present, the peradox of this gedankenexperlemnt has not been satisfactorily resolved. Superluminal communteation should not bo possible, and yet this example wotld wato to show that it is. The prevalent belief is that an answer lies in the definition of a mestrotemant process. Messurement, and the consequential von Neumann rednethon of the wavepacket, occurs only after a costract is algoed between two interacting byctems that stipulasen thoy will never interact again. That is, thejr mutuel information is discarded. Thus, the resolution of Jacobsoc's paradox lies in viewing the separatlon of the two sigals as an implict measurement, 


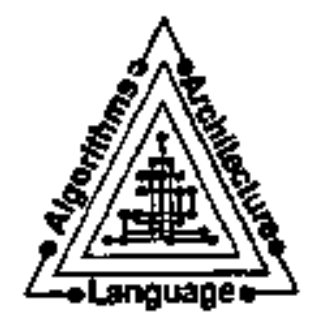

which sutomatically tollupses the throphoton superposition stute, and destroys their mutual information.

\section{Conclusion}

The rtudy of reversible computers probes a fertile dew joxtsposition of the worlds of quantum physics, computing, and information theory. Fundamental insights from this seld promise to bring uew understanding to the definitione of messurement, computation, and discipation. Hoperstly, through the creation of theories to explain quentum logic gates, and experiments to test the evoidability of dissipation, will eventually develop not only new comprtational machines and paradigms, but alsp quaptitative limits for the conputationgl performance of the physical world.

\section{References}

[3] C. H. Bennett. Lagical reversibility of computation. JBM J. Res. Dev., 17:525, 1973.

[2] Edward Freditin and Tommaca To retical Fhysics, 21(3/4):219, 1982.

[3] C. H. Bennett. The thermadynamics of computation - a reviaw. Int J. Theor. Phys, $23: 905,1882$.

[4] Patr A. Bentoft, Quantum Mechanteal Hamiltonian Modeit of Dikctete Protesses That Erase Their Own Hintonies: Application to Turiag Mactines. if $t_{\mathrm{p}}$ 21(3/4):177, 1982 .

[3] D. Devtech. Quartum compotational networks. Proc. $R$. Sac. Lond., A425:73-90, 1989.

[6] H. P. Feynman, Quantum Mecbanical Competers. Optice Neves, (February):11, 1985.

[7] A. M. Weinberg. On the relation between information and energy cybtems: A family of Maxwell's demons. Interdisciplinary Sci. Revs, 7:47-52, 1982. 


\title{
DYNAMIC TASK MIGRATION FROM SPMD TO SIMD VIRTUAL MACHINES
}

\author{
James Armstrong, Purdue University
}

James B. Amstroog', Howard Jay Siegelt, William E. Cohen', Min Tant, Henry G. Dietro, and Jose A. B. Fortes

†Samoff Real Time Corporation

Princeton, NJ 08543.5300 USA

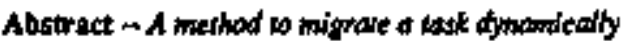

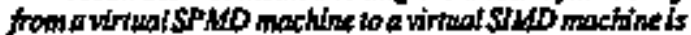
proposod If is asswedt thar the SMD and SPMD wituri wochine inodels only differ so support the offiferesrimodes of paratielibon and that die progrant was coded in a modeindependent programinitg basuse. The migrafion procedure does nat require ite SPMD PEs to be at the salute bection in the SPUO progrem at the time of the migration. This work is diroculy applicable to mixedonode hybride SMPOSPMD systems and part of the general probiens of wask migrasion in STHDISPMD mired-mechtine hererogateoursyostions.

\section{DNTRODUCTION}

In a heterogenesos sysiem $[11,30]$, cifitent iypes of

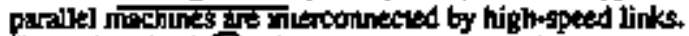

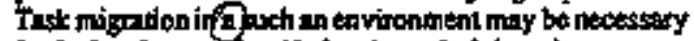

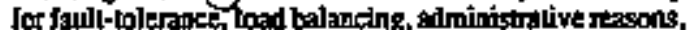
or improvingexecution fint of a single task. The migrasions

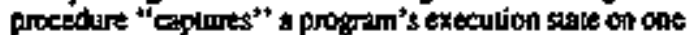
type of machine and then maps it to a viabte stace on 2 disJereat lype of machine. When task migralion is perfamed in the concexl of tault-1olerance, the "cepiaring" of the

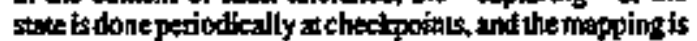
doneathe dme of the taut.

One possible toprosch to migrading a 1ask dynamilcolly bexween a synclironous STMD machine and an asya. thrunous single program - multiple datat stream (SPMD)

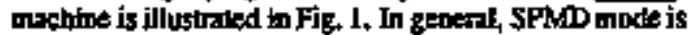
the tse of a MMD machipe when alt PES execute he samp proiralm, but nsynchronousy wilh respect lo one another. $A$ iasi is assumed to be coded th a hypothetical modeindependicar ptogramming languace, refented ba here as the VPL (virual programming language) (c.s. ELP [20], HFF

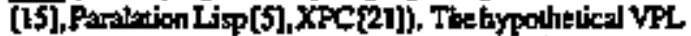
compiler generates objest code for each machine or a subser of mechines on a network ts well as produces inforats bion necesesty for the thsk migrexion procedurt. Thedouted

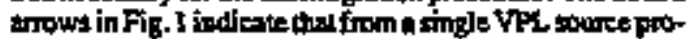

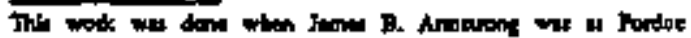

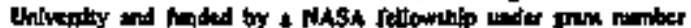

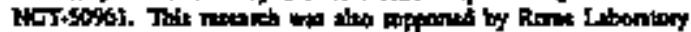

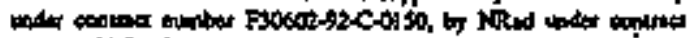

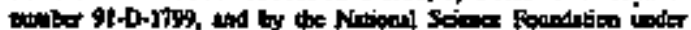

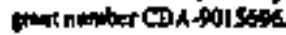

\author{
IParallel Processing Laboratory \\ E. E. School, Purdue Universicy \\ West Lafayette, In 47907-1285 USA
}

gram each machton's execurnble program is peacraled.

To move a wask fren scome physicat mashine (A, B, . F) executing it one modte of potalletiom ro anothor physicel muchine extecuting in molher mode of parillelism, two types of tenstormalions ate perfocmed that rely on intor. mation generised by the VHL compiler. The trest type of unansfocmulion (dashed anows in Fig, 1) maps the extecution stale of the lask on a partictiar machine toffom an exe.

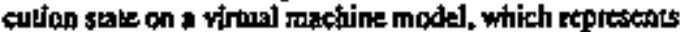
all machines with the same jpode of parilkeliss. The diffetenc shopes of the machines depicatheir differing physical archilecures. Mecharisins for mitrating tasks between differenu single-processoc conpulers, whichen be applied wo specifying this first type uransformadon, have been proposed (e.g. [10]. [14], [23]. [26],[27, [29]).

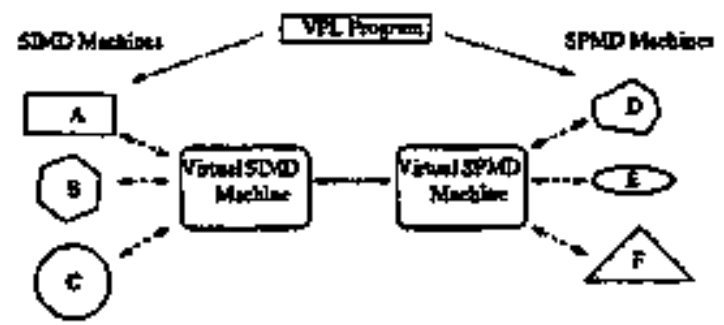

Fig. 1f Grophical depiction of tusk migrition belween SIMD and SPMD machines.

Thesesond wpe or uransiomation (solid artow in Fig. 1) conceptually mijustes the tesk between a sialeon the vif.

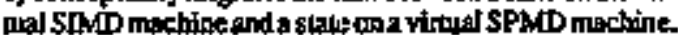
The sirnilatry of shepes betwen he virnal STMD machins and the virtual SPMD machint represents that the concep. mal archtecctures only differ tosupport the different modis of parallelism. The wotk described here adoreses the SPMD o SIMD portion of the second type of transtorma. tion. Il proposes 1 method by which a multiple instruction

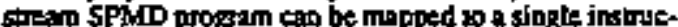
ion siream SIMD program. Tae appoach taken is to characterize a sintle insuction stream frodram and a mal-

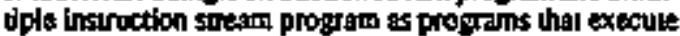
on a virtas: SIMD machino (Subsection 2.21) and virturs SPMD machồte(Subseclion 2.23), respectively.

A sencal apposath to fanplementing the second trpe unisfinmalion wes proposed in [8]. It discurses 2 way to uansiorm any MIMD program into pure SIMD code. It 


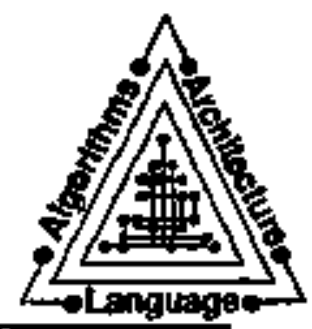

toes his by having we SIMD cods (ruming on en STMD

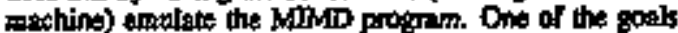
here is lohave the VPL compiler generdite efficient code for esch of the source and destination mechines (i.e, the generied code is spectically targeted for ench machine). The

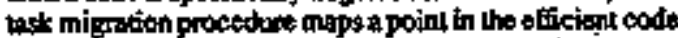
for one machire to 2 poifor in the efficient code for another machine.

This resurrch fritoseses a metod by which a poinl is on SPAD progarm cem bo mipped to a poial in an \$NMD program, assuming that the machine modets only diher wo

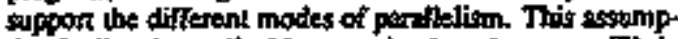
tion is direcaly applicable to a mixed-mode sysiem [7], in which tite processors of a single machitie ere cupabte of operaint in eiver the SDMD or SPMD (or foll MTMD) mode of panallelisa and can dynawiosly switels between modes at instriction-level prandla rity with relatively ofate wethead (e.F, OPSLA (5), PASM [4, 24,25), TRAC [18],

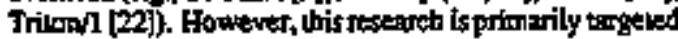
for solvng port of the generil problem of task mlgration for helerogeneous STMDSPPD mixed makting systems [30], where a stitte of 5IML and SPMD systents ate inter. coratected by a high-speed network. Ahhough pars of the mijastion frucedure implemented on the mixedmode PASM problype ts a proox-of-conceph e full ingle. menlapion is beyood the seope of this paper. Section 2 states mote spectfledily the assumptions about the protramming langus ge, operating systen, and mectine models. The lask

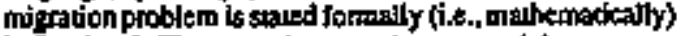
in Section 3. The procediute vo migrate a last betweet an SPMD asd en STMD yirmal mactine is presented in Section 4.

\section{THEHETEROGENEOUS ENVIRONMENT}

\subsection{Qurviow}

This seasion describes the conceptat model orSIMT.

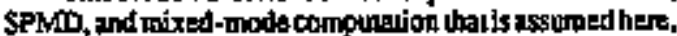
and mienions spore of the kanguage feanures that are expesed on be part of a mode-independent programming hanguge (i.c, VPL). Kalso briefiy overviews aspects ofan opefatiog sysiem harare Jetevant lothis study.

\section{Vimul Mrehine Modets}

\subsection{0verview}

h is assomed thax the virast SIMD and SPMD mpechines are as simiter as possibit, differing or'ty in the

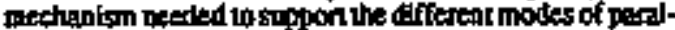
Elisn. This impliessuch latings as; all proctsors stort dals in the sime formtr (e.g. bye ordir, nnmber of bits) mesilory atidesses aro consisteat across the machines' merory lobdules (t.e., vilid addresses on one machine are not invalit on the other), the sumber of processors across madbines ane the same, and the inler-pnicessor nenworks usedin botamachinessare the same.

Funtiermorte, bath the STMD and SPMD machines ave assumed wo have a phybically dsuibuled nemory organiza- tios. In ach a cystem, ext processer is paired with a mentiry module to form a PE (puctessing element), Most

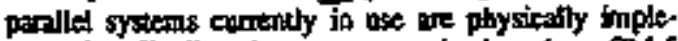
mented as distribuled memary orgentations (C.g., CM-S

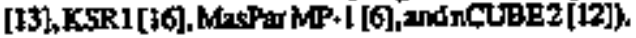

\subsubsection{The Virnal SDM Mishine}

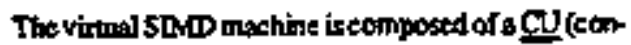
trol mit), $P$ YFes, and an interconmection netwok. The PLes are gctivied if they cen be used by the executing program

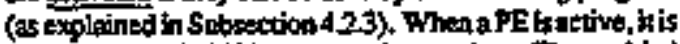

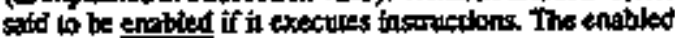
PEs receive and syrehronousty execule common instructions thal are broadrast ficm the CU. The PEs ferch dots from their individual memory modnles. The CU has the alpility on enabte selectively PEs for the exteution of instuclions. Those PEs that are not enubled tor thepertico. ir instruction being broodeax by the CU are dispiled, it. Fomigin idte and do not execule the insoruction. The incer-

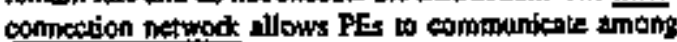
thempelves and exchange data Furthemore, the CU pro cestur is assumed w hare Creg generil purpose registers

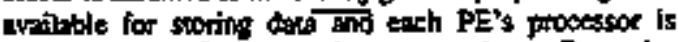
assumed to havs Sreg oeneral pupose registers. Examples

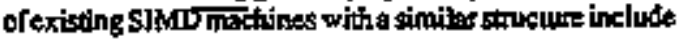
CM-2[28] and MasparMP-L.

\section{The Vitual SPMDMachine}

The virual SPMD machine consists of $P$ FEs and an inlerconnestion relwork. Exch PE's ingutetions and dars are slored in is menary modnle. Becrouse there are multo ple tureasts of control, be PEsexeruteasyachronousty wilh

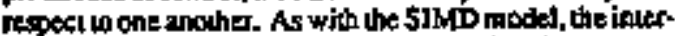
connection newwork provides commonieation lin's amons the PEs. Also, tach PE's pracessor is assumed to have Cres + Sreg ganteral ptrpose registers aritistble for use. The refistes in the SIMD and SPMD machlne models are assumed to heve the same eize. Examples of constnucted systems with a sintlar sonverure that are capable of SPMD execution factude the CM-S.KSR1, and nCUBE2.

\section{Vinn:-1Fragramming Language Feeures}

\subsection{0veriew}

Many of the aspects of the hypothectical mode. independent languge, VPL, ars based on the existing Dt $P$ lanizuase [20]. The overiding concen wilh VPL is to insure that the bigrage definjlion is mode independent.

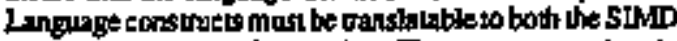
and SPMD modek of execution. Thes, constritets bere do aot horke a translation to both models of execulion are illegal. VPL is explated here using a C syniax with exten. sions.

Like C, VP, hat poiners, However, peinters bo local variabtes are jlegalbecanse the migracion process changes the localion of ratiables in the stonks and hy trastition of the poimers to the new gdresses would be an expensive 
operation to iaplement The other semantic diffecotes frota C arsowing of VPL aving more than one flow of conoot in the program. The feames unique of VPL will be dis-

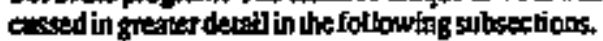

\section{Variable Amibois:}

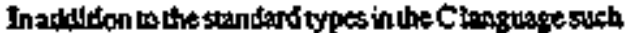
as itf, theot, and double, variables in VPL aloo have ntritbues that describe the location of the rariables and the opes of operations possibte on the varisilles. These altriburtestet monoand poly.

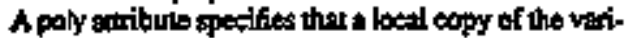
the restres b cach FE ha the machine. When apoly expessionis being evallualed, exch PE in the machine is operatiog on an ind -pendent confy of ths poty variable that is localed in istiosilmenory,

A rariabie declared as mong effectivety hes onecopy atoss the entire machine In parieular, on 5ilm muchines, a mono variable would hive a siagle cory stoced on the CU. Operalions lewalving anily mono variabtes and constin ls art texecutud on the CU. This artay lead uo benter STMD pertocmince then if the vatiables were present on each of the PEs [2]. In soptros, on 2r SPMD machine, a loces copy of inemons variable ts sworedonteach PE.

In SIMD mode, for anf opersions then fowolve bolh mond and poly vistbles, the mone variables are broadeast to each PE and the operation is thes performed in parallelon thePEs.

\subsubsection{Flow of Conuol}

If a couditional stalement constis of at least one poly virible, the conditional s considered to be a poly condi-

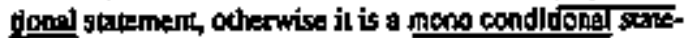
ment During axecution, ench PE on an SPMD mathine is

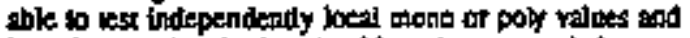
branch ardind code that stostid nol bo execuled. in contots, only the CU on the SIMD maschine can execule jurp insinuctions and branch around sections of codt. A mong expditionsl exptession is evoluated os the CU in SIMD modie and hus ibe execuloon af an fi, for, while, dr do stats.

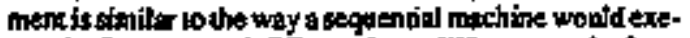
cule li Becanes each PE may have dillerent results from evaluariog a poly conditions exprossion, epach PF may

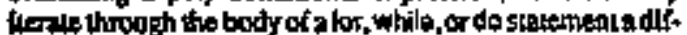
ferent nomber of times. In SIMD node, when a PE fails a poty condituonal test in afor, whil, or do staternen Lit is dis. abled umil all PEs have failed the poly condtitions. Simi-

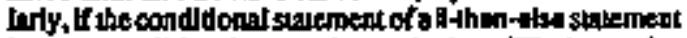

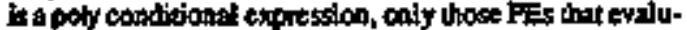

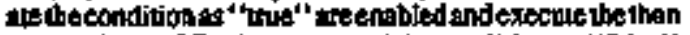
clunse. Those PEs that evalualed the condicion as "False" tre disabled untifl the then cifalse has benexeculed by the costiled PEs. Only those PEs this evatuated the condition to be "false" are engbled to execuse the olsa clguge, and the

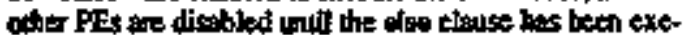
coted by the enabled FEs. It is assumed in this paper that

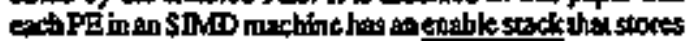

the PE's enable ataous for various depth nestings of poly comditiont exprestions (as In, for exemple, the Mastar MP+1 and the CM-2).

To unify the representadion of SIMD and SPMDConditional execution, the VPL compilet imposes sevetal res. trietions. One of the tesarictions that was proposed for the

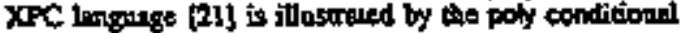
below.

$$
\text { Q (FEnama-OY(A) abu (B) }
$$

The dffference between SThD and SFMD execution is ths ordering of the execultion of streftens $A$ and $B$ by the PEs. On an S1MT machine, stererrent A would ex Exut: beforts

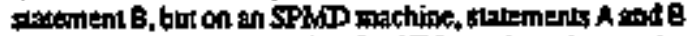
mory execote concmrendly. In VPL, unless th can be

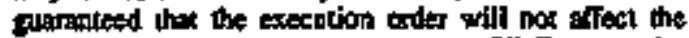
festle of the thethen-alse stiternent, the SMD sempintics weenforced.

\subsection{Inler-PECommunication and Syachromizadon}

The operations thax can affecl ordering of stalemenk execution across PEs are inter-PE communiceltons and synchronization operations. In SAMW mods, ypically when one FE sind dalk to ano herFE, all ecrabled PEssesd deo to other distince PEs, Thertilote, the "send" and "recsive" commands ere toppticidy synchroaized Beculse all enstled PEs tite following the same single instriction streom, exch PE kJows from which PE uhe anesonge has been recelved and for what use the mescage is intended. Thus, no bolleriag of mesenges o explicit mes. sage ideaticication is nexded. Conversely, in SPMD mode

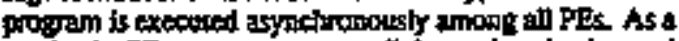

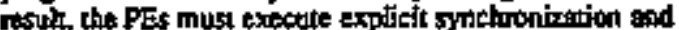

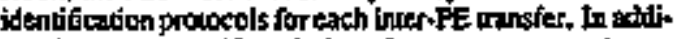
ton, becruse a spexific ordaring of mossagercanonot always

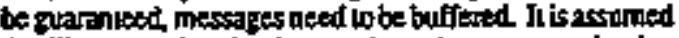
that Ebray Jutines ing itement he various commmietion prococats. For the migralion process dferussed, it will be aecessary Jor an tiniemeditate SLD profram to make wese of the explicil synchronization and idenofiticalian protecol. as well as the buifering mectsanism, which is normally associaled with SPMD minsfers.

The approach used fer updaling moro vartables in VFL, which is the same as in ELP, is b disollow assignments iomono variables within poty conditional sactements bectose the coliterence of the mond vatiables cannok be gurranteed. This impiles that an wry poitht in time, a mono varielle may bave difeecm valuss on diferenk PEs in an SPIDI machine; howewer, if will have the srme value atross PEs at us same location in ahe SPMD progran.

\section{0periting Sysiem}

\subsection{JOvervitw}

Miny partt and deteils of an operaling system must be considered for the peneral cuse of misrating tosk between two machites [23]. However, this subsection focuses on the parts of the tperating systern that miquely impact the 
atgracion of i progratn between two machines that have differemtmodes of paralkelison.

\subsubsection{Menory Layout}

One appect of the Cperaling system that is porinent 10 this stady is the vinun adtress space. It is assumed ther mono and poly global variables shrere the same virusal adtress spoce in eact FE, but are grouped inco septralt memocy segunenis. (In STMD maxhoues, the mono vitioble

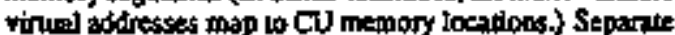
mono aff poly "heap" deta segenenis also exiss for dyramic memory allocation. By mating a distindion between mono and poly dath segments, the motibction of the virinetzidres bables irsimpitiod.

A VPL subrootine can have both mono and poly paramesers and kocl vatiptes In SEMD mode, upon the coll of s submutine, stect space for mono parimeters, mono Iocal varables, and subroudires' remm gddiresses is allocoled on the Cl\}. The merrory space fios poly parimeters and poly locd variables is allocand on the PE stack, is in, For example, the MesFer MPL programming tangtange [19]. in SIMID modte il is assumed the CU and each PE has a frane pointer that poins to the localy sisned stack (e.5. PASM prolozype). Io SPMD mode, mero and poty parameters aud Local variables are pueshod onot the PE gtork, Swek and frame pointersare keplin exch PE.

ldeally, within the uset steck, mono and poly locel variables and paramejers sthould have separate segatents as well. However, bectinse local variabius and parantelers we stored on the mon-ine stock, septralle stecks would be required. This tonptites that th SIMD and SPMO machines have separale stok poirter registers avzilable to be nesed tor apohy yuriable sinck and a mono vartablestack. Whilesoene SIMD muthines (e.F., MasPar MP-1) may bive this tearere, in general SPMD michines donot. Thus, monoand poly local rariabies and parameiters are sesumed to occupy the samemetnory separentin this discussion.

\section{4,37rogran Migzation}

When a signal to migtate Uhe program is received by the SPMD machine, the djperning system musl save the salle of the progrem so the paogran can be restarted ax the approprisate point on the SIMD machint. In adtition os the mernory image, the cpersiong system stores other informts tion, such as: messiges is processes on the sane PE and differenk FEs that have nol been zerly, messoges received by 1 process bul nox read, and inter-prosess and Inter-PE comminicition paths torablisted. The operating system is also assutied to have the npability of "flussing" alessoges front the inter-PS nctwr-k (0.8., CM-S operaing sysuem [13]). If the networty is a packet-swikhed mntistage nelwoxt, some packets may be blocked within the retwark al the time a process is intermped o be magped to another machine. In this cast, the operding system "G ushes" the nelwork of the meresges, so thel all messeges zre saved as partol the " "per process"' information mextioned abover.

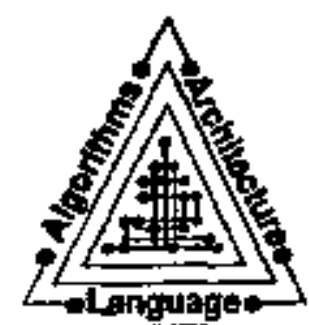

3.1 God

Let a VPL progrars, $F$, be compilad lo produge in object code program, s, for a virturd SDM machine and an object cose projum, $\underline{H}$, for a virind SPMD machine. Eitute in SIMID mode (dure wemabling disabling or SPMD mode (dos b brencking). not all PEs will necesterily execule the same sequence of Iostructions. $\dot{s}_{1}(x)$ depotes the sequence of states represeting her collective actions of all $\mathrm{PE}$ that occur during the execulion of the entirt SIMD pros

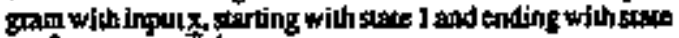
o. $\hat{M}_{17}(x)$ ts de fined similarty for the SPDIDprogrem. This

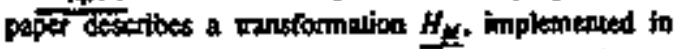
STME mode, SPMD mode, of mixed-mode, such that

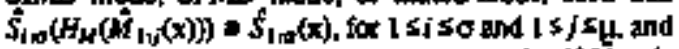
for all $x$. The equivalence stalemest means bha if $M_{j ; k}$ is folemupted at sorre point having execuled the sequence of stales $H_{1, j}$, When $H_{M}$ can trabsion the resul|s compuied by $\hat{M}_{1+i}(x)$ in a form that STMD mode), so that the result is the sante as that found by $\hat{s}_{1 \text {. }}$. In other words, $H_{W}$ wanstoms the resuls of $H_{1: j}$ is yield a valids stace of $\hat{1}_{130}$. No parricular mode of perilletests is specified for impiementing $F_{\mu}$. because It can be performed lotally in SIMD or SPMD mode, as well as pardaly fn either mode (le. mixed-mode). More details aboul the mabtom:ócol modelarein [3].

\subsection{VPLProgran Charecterisoics}

Bessuse the two machines suppar wwo difterts modes of parallelism, thert may be points in the execuuion of the progratn on one tachine that io nox comespond is points os the whes. For example in STMD modte, a mono rariahle may need to be breadcast to esch PE to be added to a poly vatiable. The "broadcast and adtition" ipention may require a sequence of insmuclions in the SIMD code. bui only a siagle atdition instruction in the SPMD code. The staie of the SADD machine during the execotion of these instructions may nox comespond to a slate in the SPMD machine Anglher erariple to that the SPMD progam may need v identify sarsferced foromation expli-

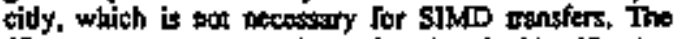
SPMD alachine stals while pertoming the idenuffication protocol may nolbeequivalent lo any S] MD machine stane.

To makt all possithe interruptible points in both progroms "equivaless," the VPL compiler divises the objecl code programs $S$ and $M$ ino uninternodible thacks of instruclions with the following propenies (1) bere are an equal number of blocks, $B$, generaied from $S$ and $W_{2}(2)$ the

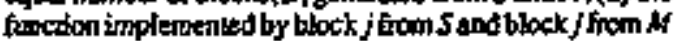
are equivalent jor $15 j \leq 8$, and (3) no block in tilher $S$ and

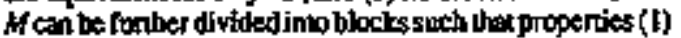

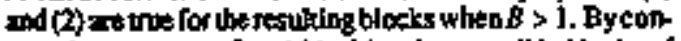

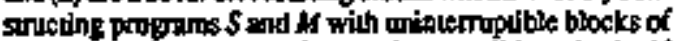
insoructions in this wry, for thy inceroupdble poin in $M$ thereñs an equivaient pointins. Analgorilbut thal performs 


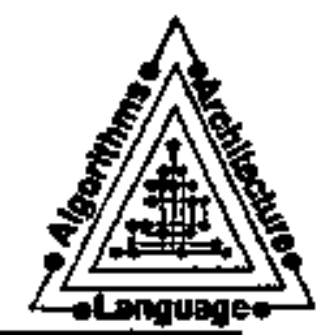

His finction is given to (3),

\section{SPMDTOSRMD}

\subsection{9veriew}

This section fiscusses the trantiormation of the

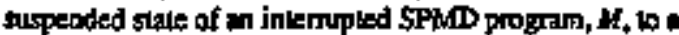
staie in an equiralent SIMD propan, $S$. Recall thac pogams ean be inierropied only a block bamdarits, as

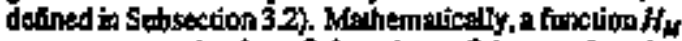
ons mesenied in Subsethon 3i, wh wal $\hat{S}_{j, 0}\left(H_{M}\left(\hat{M}_{j,}(x)\right)\right)=\hat{S}_{5 \rightarrow 0}(x)$, for $1 \leq i \leq \sigma$ and $1 \leq j \leq \mu$ and $f \alpha$ all $x$. $H$ ter, one possible implemectation of $H_{\mu}$ is desctibed An extimaled worst-case asymptotic time complextity for each part of the migraion procedute is given.

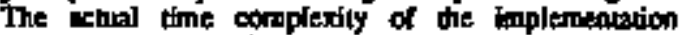
presented here is applicarion dependent

An ifmportank designt requinemert of $H_{M}$ is that wher $M$ is inlemupted, execution of the progran lo be migrated on the SPMD merhint must end "quetckly." Thats is desijshite becsose it allows the prompt migraton of asksby load bateneing roulines. In the conitex of fault-tolerances, interrupscan be esed by the opetaling system wo checkpoix the nempry imase of $M . M$ can then be chackpoirted periodlcoll'y in time instead of at specific locationsin theprogram.

There ars severif diall soructures that wee assuned to be produces by the VPL compile tor each program that provide mapping information between the $S$ and $M$. The mappings benween the memory addesses of subrostinecoll instinctions and betweet inkerupible poims in the SMMD and SPMD programs are kept. This information Es used by $H_{y}$ to map renum addresses in $M$ wothose in $S$, and is stored in a lable called uhe ART (address resolution able). This lable, therefore, provides a mapping from an irstruction address in one progran wo the equivaten instruction address in molher (fr all those aidiresses dispussed shovel.

Giformation athont which lecation on the PE sack is occupied by a mono vitisble ts also kept. The VPL compiter produces unts information tor eacb subrouline. This is done effociently if the VPL compile wittes antordering on the stack of parameters and local variateles. For exampls. the VPL comolles can push all mono paramesers on the

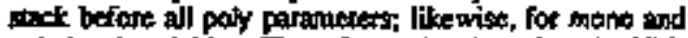
poly local variables. Then, Lo exch subroutile, the VPL compilet associtites a loctlion on the stock the separies mono abd poly parmeters and mano and poit locit rariables. This infermation is stoped in a SST (subrovline stack

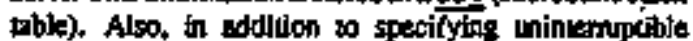
blocks and relum address mappings, dos ART mups all uninuerruptible blocks w the entry in the SST for the sub. coutine in which uhe blockssappear.

Finally, each ART enury conbins a pointer to the entry In the ART of the block then ripresents the conditionistarement in whose scope is atpesis. If a block is nol withto a canditional stavement the poiater is mutt. The paitler fields for blocks tepresenting sobroutio entry poirls are also

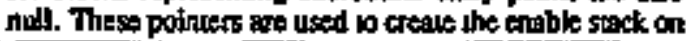

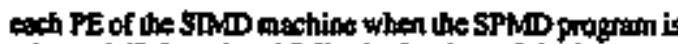

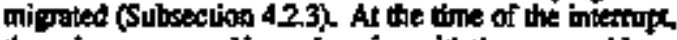
the potniers ree need in confunction with the renurs address volues on the nur time sesck of each PE (ghowing the sequence of subsoutine calls) vo dectimins the nesting of conditionals at the time the 1 e was inlerrypted. This informadon can uhen beused wogeale the PE enable sind on the SIMD mashine

The tiscossiog fstividud in deternines the strting instrucion address in $S$ given on intervped $M$, The second part presents how a vialie sart.

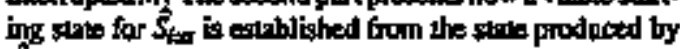
$\boldsymbol{A}_{\mathrm{j} j \mathrm{j}}$

42. Devermising

\section{2,10werview}

At the time of on inturvpl of $\hat{M}_{1,1}$, beconse the PEstars

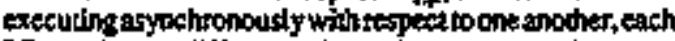
PE mry be it a trfferelt point in the execulion of the progrom. Due to the symetronous namre of $S$, the muld ple individual PE states of $\hat{M}_{1, f}$ anus be mapped to a single state in

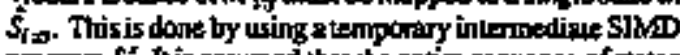

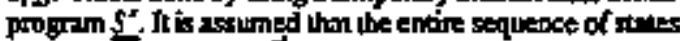
af $S^{\prime}$ is expresented by $\vec{S}_{1 \mathrm{~g}}$, TheSPMD machine is notesed

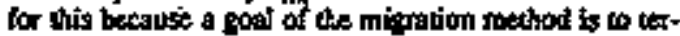
minate extecution on the SPIVD machine as "quiclity" is

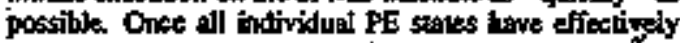
reached the atme point in the $S^{\prime}$ proprem, the stase of $S_{40^{\prime}}$

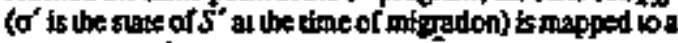

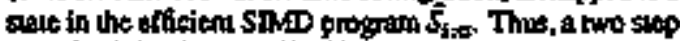
Irappiog is inpitentented by $H_{M}$.

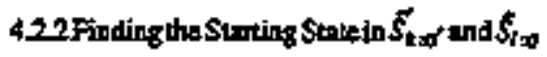

The difficalcy in finding thestariog stace encountered

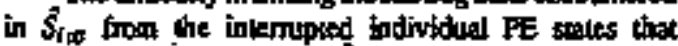

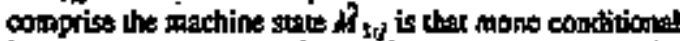
bopstalements are par of the VPL bangange. For exaruple, if two fE states are wilhis a VTL mono condfiongI loop statemint, then the monto Ixop control varitble ind the and-of-loop mono conditional test aeed in be checked on determine which value for the nono loop consol varizble from the two PEs shatid be used for the srating state. In

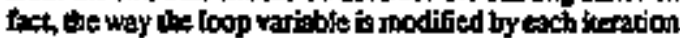
must al ma belerown.

Fir. 2 illewayes the type of decisian $H y$ must make. Suppose it the time of ar iniernpe, PE 0 was al $m_{1}$ when $i=6$ and $P E I$ was ox $m_{2}$. when $i=8$ (astume $P=2$ ).

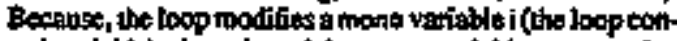
nol variable), the volue of the cono vatetede $11 \mathrm{~m}_{\mathrm{H}}$ and at $m_{2}$, and the way it is modifect (decremented), needs to be ennsidered. If $H_{H}$ eraluates the $\mathrm{BC}$ (progrem counter)

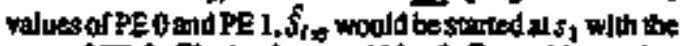
state of FE 0 . The I value would be 6 . From this staring

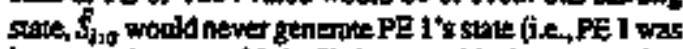
incrupos at $m_{2}$ with $i=B$ ), because if is dectemenced at 
each iteration Becanse there is a sivgleswrate toction for

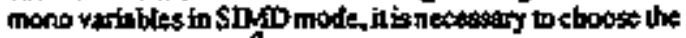

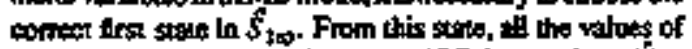
the mono rariabies In the interrepted PEs' stales from $M_{1 j}$ will betencounkered in $S_{j \text { if }}$.

monotidi:

To avoid having to check the values of the morto variables and the way they we upiated, in intermediate pooaram, $s^{\prime}$, Is gentrowed by the VPL compiler, This fruermeedian program is an equivalent SDTO progrim thal has ca mono yariables. $H_{M}$ maps te rafious saus of $M_{1 ; j}$ lo a

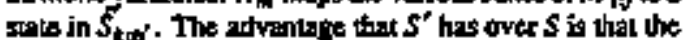
number of times a loop isexenated is deterrined by the PE and eol the Cu. Therafore, to map the states of the inrer-

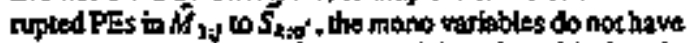
to beeve hested to deterinine st which iterasios of the loop in the \$DM ptogram processing begins. Onedisedvantage $\alpha$

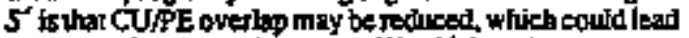
to pocrer STMD performmes [(2). $s^{\prime}$ is toty used lemporarily (ie, it is in intermedinte progeras). Once all the PEs have ben acdialed and they are not execming a loop statemest that cortesponts wo mono condilional loop suatr. ment in $S$, the stake of $\widehat{S}_{t \rightarrow 0}$ is mapped to a stale in $\hat{S}_{t \rightarrow 0}$. It is

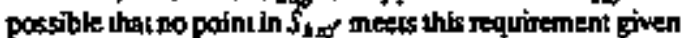
the inatemupted staits of the PES, In which case $S$ is never invoked.

Fig. 3 stows the sime code segment as that in Fig. 4. Aqoin, it is assiumed that $P=2$ and $P E 0$ and $P E$ I were biecrupied at $m_{1}$ and $m_{2}$, sespectively. In this case, $H_{H}$

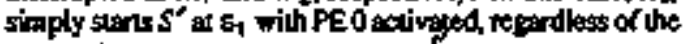
walue of $I$. PE 1 is activited when $S_{t x x^{\prime}}$ resches $S_{t}$. Ths loop's poty conditional exprossion is evalualed on each PE. Ac the end of the loog, assuming all FEs ante activated, the stale of $S_{* \neq a^{+}}$is mapped to a valid state in $\bar{S}_{k \neq 0}$. Thus, in offect, $S_{t \times 0^{\circ}}$ synchronizes the intersupted states of the PES in $\hat{H}_{1, j}$ to yteld a valid state in $\hat{\hat{S}}_{i}$. Thesynchronization is nox done on the SPMD machine beconse it to 250 med that when as interropl oceurs, execuiton on the SPMD machine must end "urickly." Beconse symchronfeing the FEs lakes an iadefinitely forg period of time, it is done on the SMM machine by 5 . Clearly, if the onginal SPMiD loop used a pohy conditionsi the sante behrigue would apply. If the Inop body contaites mier-FE dala transters te is nol s prob-

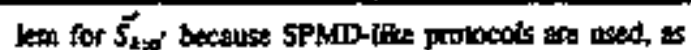
mentioned in Subsoction 2,33 and furthex discussed in Sobsection 4.2.3.

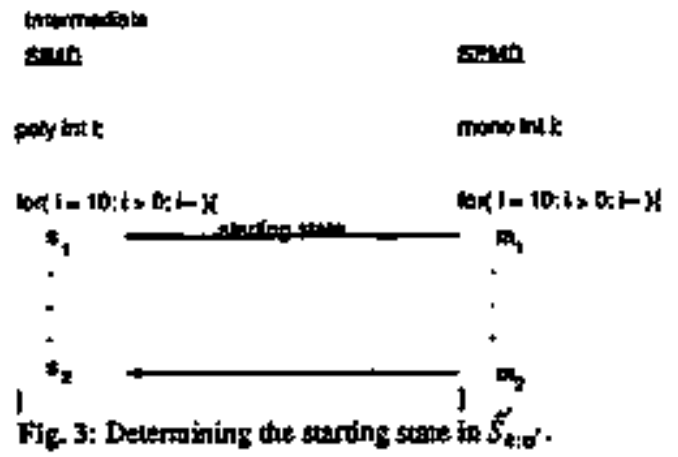

The PCraliess of the PEs at the time of the incersupt of $M_{1: j}$ cannox be used alone ioderemsine whercin $S^{\prime}$ cormpovation shoult begin. This is becaose esingle sukroutine can be celled tom more dan one place in a program. Conse. quenty, no PEs con have a PC value in ithe some subrot. tine, but the subrouline may have been called from two

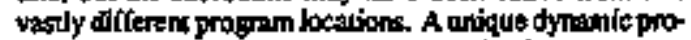
sam posilion can be computed by eviluating the retarn addresses stored on each FE's stack. These vidues together With the coiren PC valoe specify a unique program boca. ion. Thos, to find the PE staie from which $S_{t \rightarrow 0}$ shonld be sparted, the reinm valoes of each PE's slack are corppared in the onder that iney wers purbed on the stak. This fon be done by a seequence of recursive doubling operations. The program becation in $S^{t}$ that is "ckrsest vo the beginniag" is chosers as the thating stite.

Now, consider,the vime complexity of binting the staring loction in $\vec{S}_{\text {txo' }}$. Asstipt that the pesting depth of subrotuines is $\hat{A}_{1 ; j}$ is $d$ and the number of $P E s$ is $P$. Then the wors tase time complexily to compare by recursive douting be return address values on each FE's stack and ueit PCralueis $O$ ( $d$ iog $P$ )

\section{Dewrmining Whan wActivaresE}

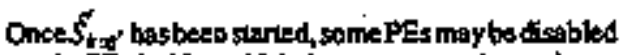
because the PEs in $M$ to which they contespotd were injer.

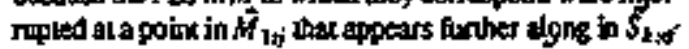
than the stuting stale. APE is activated when $S_{4 x}$ teaches a program localion thalisecoivalent al which it was inienupted. However, becanse a PE may have been imenupied afier any oninlemgitible block of instructions, in would be cosdy to have $S_{k \neq 0}$ chick, sfler each untinierupifote block, if any pess sould be activaled.

For this reasob, $M$ can orily be halled aler specific

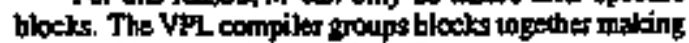
the set of bloxks uniniemuphile. The complier groups as many blocks togther as possible wilhow reducing interropi tesponse ime to unaceeptabie lewels. For example, if 


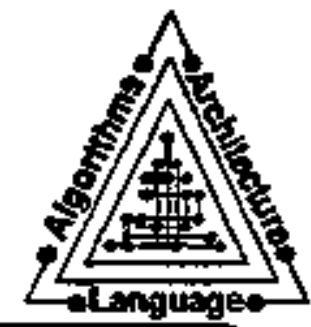

the response time is set al .01 seconds, then the VPL com. pilte would odly froup blocks together that would pot exceed .01 seconds $1 \mathrm{n}$ execute. If the compiler does not trow how many times a loop will herotes thes at leasi one

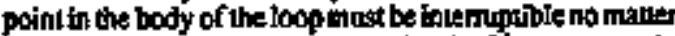
how stipit the kop is. Subsequently, the $S^{\prime}$ properm only nasdis to checl if iny PEs need to be activaled at the toxt-

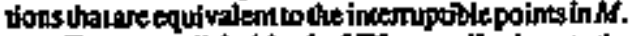

To accomplith thts, the VPL compiles ineerts the fotlowing code segmente equiviolest points in $S^{\prime}$ as he intarropulblepotastin $M$ :

SKIP:

goNoSKIP;

Gathate_PEr(romup, Ext);

As shown, the subroutine activale PEst) is ax reached bectuse $\alpha$ the goto instruction. Altowgh this code seg.

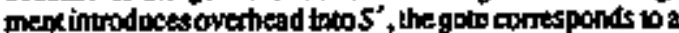
jump instuction in a processor's objed code ind is expected to huve nomind overhesd. The amount of over head depends toon how frequently the code segentent is encounlered, which is a function of the internipl response inein Mand how short souleloopsere.

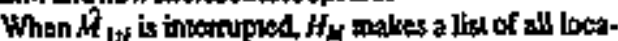
tons is whith FEs wete internupoed as well as which thes were inlemupted ac exch loxition. Then for esch Ipation in the list, $H_{M}$ overwites the goto insurvation with a fop instrued on th also wries a valot for titt thax is passed of

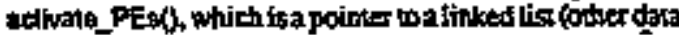
structures ctan be osecos) of PEs wol have been halued in $\hat{H}_{1, j}$ of the equivilent Iacotion. Then, whenever $\mathcal{S}_{5}$, texhes a Doint when a Pet may be activated fl impoles yhe subrouline activate_PEeli) pasting in the lia of PiEs that may be ativaled. Nor all the PEs fon the lisi passed o it arv neces. strily going to be activaled $a$ esch isroction of acthite_PEs0. This is because the fateruped location

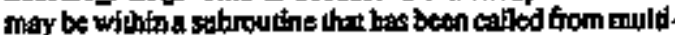
pleplaces in the program. To activite the appropriane PEs,

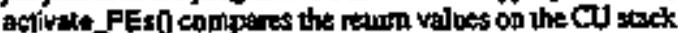
and the current PC value to that of thase PEs on the list passed oil. ThosePEs whose fetem values and PC valuest

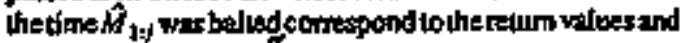
PCvalue of the CU in $S_{t \rightarrow r}$ ive activaced. Wher all the FEs

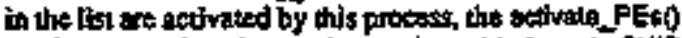
toutine overwitics the nap inspuetion with the golo SKIP for the locition in $\bar{S}_{k+0}$ from which it was invoked. This prevents $\hat{S}_{t+0}$ from thecking whether any PEs need to be activiced ox this kxestion, becinse all have been.

As mentioned in Subsection 2.3.3, ench Fis has an enelble srack by which it detemines if $\dot{x}$ is enatited or titsbled for an SIMD tnscruction. In SPMODomete, the PEraro never dicahled and thus do not have an enable stack. Thus.

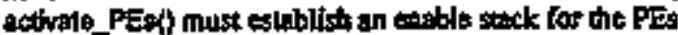
that tre actived. This is done by using the infortsotion in Jhe ART in confunetion with the fetures addecs vahues on the run-inie sinck. Fot the PC and retam address values, the ART hus a potinls to thectional statement in whose scope hose instroction add tesess apper. For exch addiss, the poinlers can be toned until a mill pointer is found. By adting the tumber of these non-tiatl poinsers for eqeh

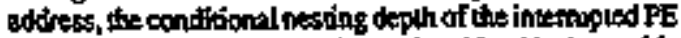
can be deaermined. From this aumber (depuh), the envble sladk can be forded (17). If the contitionsl nering depth in

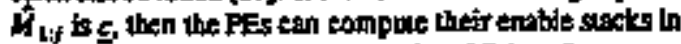
parillel th wotst-case timecomplexity of $O(c+d)$.

Given the medhod of exivating PEs, a problen ansy

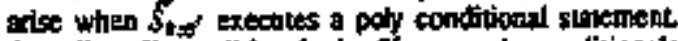
Actually, all conditionals in $S^{\prime}$ are poly conditionsils becinse hate tre no mono variables Assume that he poly conditional stalement disables all sective PE. This woutd cause $S_{t+0}$ to "sitp" the thin ciluse of the poby contiionvl. It is possitie, howeve, ther pome deacutraled PEs would be tetivaled intide die then climese. By "stipging" the (hon clmase, $S_{\text {bo }}$ may lesve hose PEs deactivated permenently. Thus, for tach goly conditiontal slavetsent that

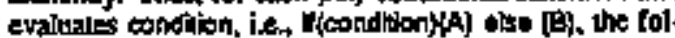
Igwing conditional test wousd be pertormed insead by $S_{\text {it: }}$

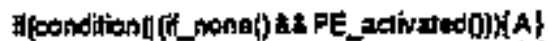

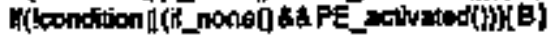

The Insomali Joutine derersines if none of the sctivaled PEs are entabted aflor andition ts evaluated and

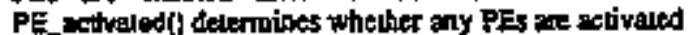
withis A ar B. The then elause, A, is laken ff condition is

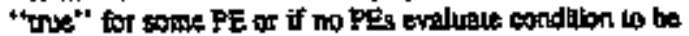
"trie" bu some PEs witl be crivated in A. The olas ctause, 9,15 execured when any Pts evalualed tandilion as "I lase" in if no PEs \&valtated condlion ss 'false'" but al teassone PE willbeadvatex in $\mathrm{B}$,

Todedermine if any of the PEs witl be zetiraled ta A or B, the $C 3$ muline PE_ativalod0 uses tis ART wo find the

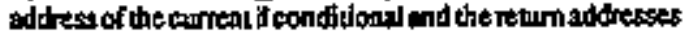
on the run-ime stack todelermine hecorrent dyramic program localion. The address of the d conditional and the dyramic progran location are then brodedest to the fuac. uive FEs (the operritg system can can activale them ternporatly for this operalion), whict use the informalion in

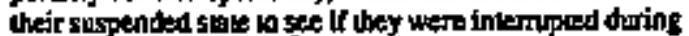

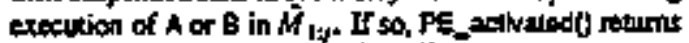

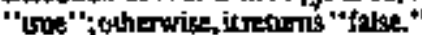

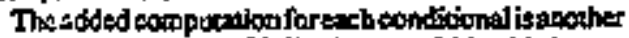
source of sneffeiency for $S^{\prime}$. The impaciof this addedowerhesd is dependem upon bowr ramy condition:al statements disoble 세 aclive PEs. This nomber is apglietion depen-

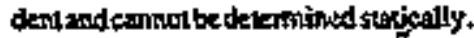

Inaer.PE communitation in $\hat{S}_{\text {a }} x^{\prime}$ also has added over. hend. Because the PFs are no necessanily actraled at the same point in the pro grow, iftor-PE messages Jpust be buftered. Some FEs may not have reached the point in $\hat{M}_{j}$ where they twad messeges $\mathrm{kem}$ lo Uem. These matsoges must be boffered in $S_{k x}$ undil the PEs read them. Furtier. mons. the ofiter of the mesinges in the beifter is por known ond thus a messege idcadibcation prococol is necessary, the

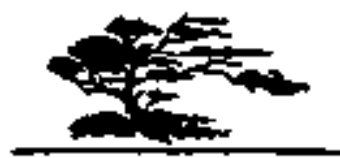




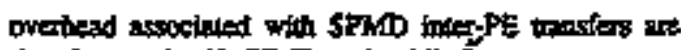
therefoce reathed in 5IMD mode while $S_{\text {ho }}$ executes,

Becanse of the ovestiend in $f_{k, 2}$, is desirabie to move to 5 as witky os possible. Howtever, the PEsaust be syuchronized betore itis happens. Symchrgnizalion is guaranued whel all the PEs arc active, and $\vec{S}_{k \neq 0^{\prime}}$ is nol is

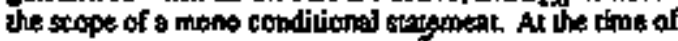
the inetruph, $H_{X}$ computes whese $S_{k \rightarrow 0^{\prime}}$ with be haled and is stuk mapped to a stote in $S_{i x^{*}}$. This is determinet by

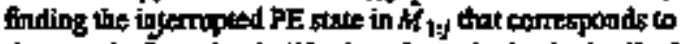

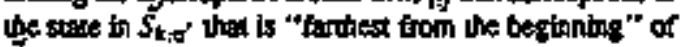
$S_{t a 0}$. Thes is done the same woy the "closost" seate wat found. Onex the "forthest" the is fourd, H Hetemines which of the internupible locations is nol withis a mono conditional loop in $S$ that is at of past the "fancest" beca don, For this tocuton, a nop is winen aver Uhe golo \$KK

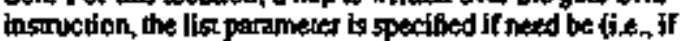
any PEs wilt be activaled hert), and the remsp ffact, tonep.

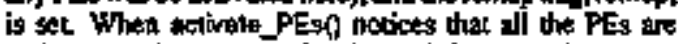
aclivaled and the remap fiag t sex, it inwokes $H_{M}$ to map

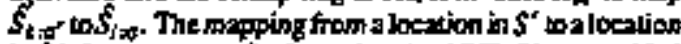
in $S$ is just 8 maner of referencing the ART, $S$ has no added overhead owtag in the temopping procedtre and con be as Adocientasposstbie.

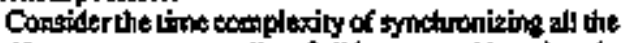
PEs. $H_{M}$ motrconstroct a list of all interupted locsions is $M$, which would take ia the wors cuse O (P) time. Then whenerer adkate_FEsU is called, fi cherks whet PEs on the lis should be actiraled. This is doene by comparing the remm address valoes and PC value of the $O U$ v hose of the PEs' individual intensupted states in H. $_{1-j-}$. Thes if the maximsm subroucine nesting depth to $\hat{M}_{1, j}$ is $d$, this abes.

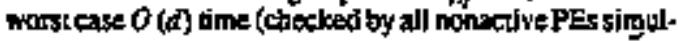
uneousty). $A$ lso, foc exh conditional slakement in $\vec{S}_{2 \neq 0}$ wher atl active PEs are disobted, $O$ (A) comparisons take place. Suppose the aunber of such ornotitionals execuled is Noond. then an overaegd of $O(\Delta \cdot$ Ncond $)$ is ireured. Finally, to devermixe the point at whlch $S_{2.0}$ should be thapped of $S_{i x g}$, the "farthesl stwet" from the begioning of $\xi_{n} 0^{\circ}$ peeds to be found. This would take wors case $O$ (d-logP) time (sme os finding the starling stade). Thus. the lotol worslcese tintecomplexity in synchmonize the PEs

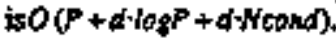

\section{Specilyton $H_{M}$}

\subsubsection{0varien}

Thit subsection specifes Dow $H_{\mu}$ maps the stite of an interropied SPMD program, $M_{1 ; / j}$ joa valid suartiog stace of an invermed hine \$IID program, $S_{t>0}$, and uhea how a scate in $\bar{S}_{t ;} e^{\prime}$ can be mapped io a state in $\hat{S}_{i=0 .}$ where

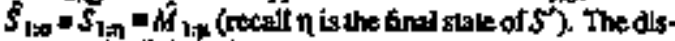
cussion is divided into line parts: remapplog the stack,

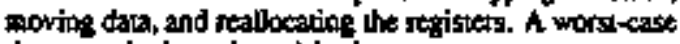
intecomplexixy codoesch is given.

\subsubsection{Rerapping mestack}

Torentap 由esack frop the SPMDFEs to both the CU and YEs in the SDM thechine, the SPMD machfae's PEs' stret is divided aroont the SIMT machine's CU and PEs. The portions of the SPMD PE stak ther gets copied to the Stuib CU stack do the mond wemporary and local vari. abtes, mono parabtekers, and the subrouline ream ditesses. The SEMD PE stack wil recelve the poly temporrory and local varibles, and poly paramears. InformaJon abour which kocation on the PE stack is accopied by a mono variable is iept in che SST (Sobection 4.1). the SPMD code sabroutint tehur addresses ane mapped if corresponding SMD codte addresses using the ART. Frame pointer for both the SHMD CV und PE strekseas be derived fior the SPMD PE trane poinut. An exemple of

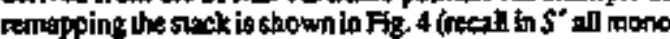
pariables are made poly variables). If the FE slack has gritze mono sack varinbies and potize poly stack variables. the wors case time complexity reguired to rentap the slacks

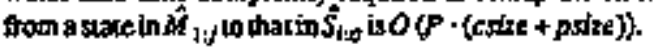

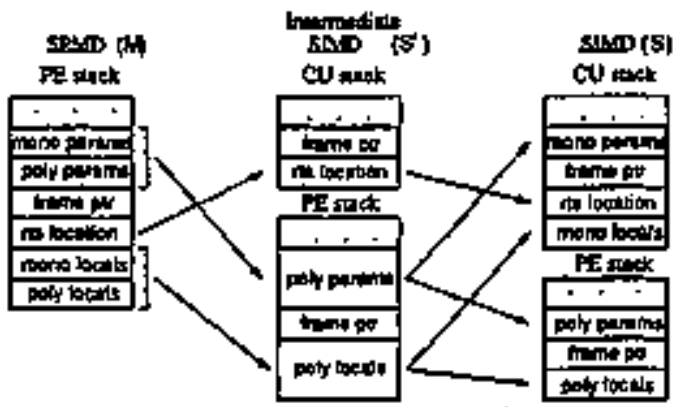

Fig. 4: Remapping the sack from $H$ to $S^{\prime}$ and from $S$ io

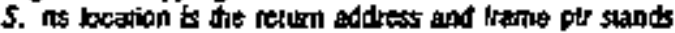
for farte poinuer.

\subsubsection{Maving the Data}

Becruse $H_{M}$ is a two sep peocess using an imermedi.

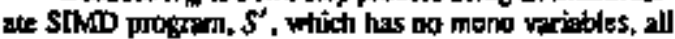
mono variphis in $M$ mus be realed as poly voriabies in $S^{\prime}$.

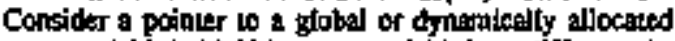
mono variablesia $M$. If the mono variable hasta difierent virual address in $S^{\prime}$, the poimer would need wo be remapped accordingly. To aroid this added owethead. $H_{M}$ maps the mono vardables of the SPMD progetm to the stme vinual addess foctations in $S^{\prime}$, even thoush $S^{\prime}$ has no mono variables. This is shown piemorally in Fig.5. Storfgpoly data in what is normally a mono daia scomeat may prtsenla probIem If the virual addrest of the operronds determines if an instuction opereles on poly variables of mont variables. It is assonled, however, for the STMDO virtual fonchine used hert thn samething owher thin the virtual address is used vo specify operations an poly or mono dasa $\left\{t_{-} \mathrm{B}_{n}\right.$ the opeode for MaxParMP+] andPASMD.

The second step of the rapping occers when a stote is 


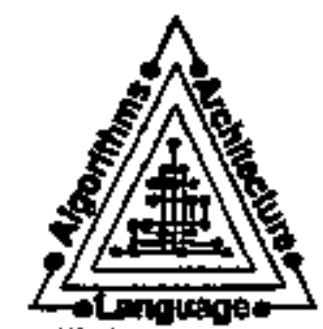

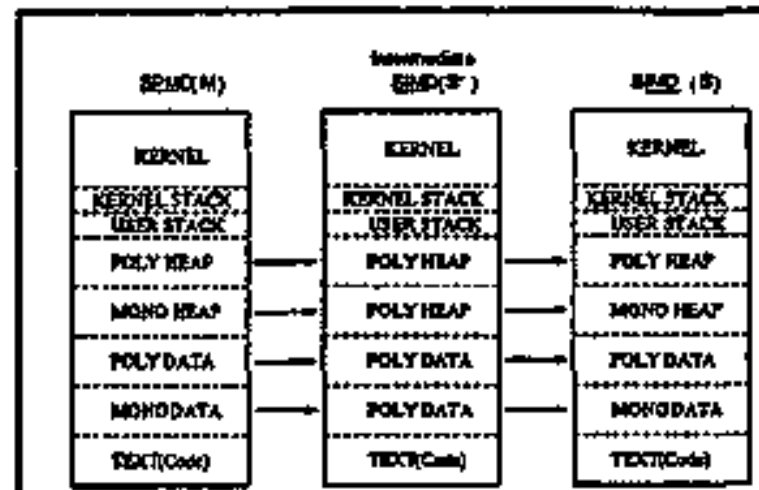

Fig. 5: Dan mapping from $M$ wo $S^{\prime}$ and from $S^{\prime}$ of $S$.

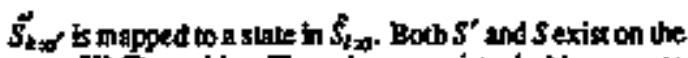
same SIMD machine. Thus, the same virtul atdress space can bestared by both programs. They can alsouse the same page ables. Only mono data needs is be moved from the PEs woheCU and their poge rable encries remaiphed during thissiap.

If uhe number of mono and poly variable data bytes ts Cdayc and Sdate, respectively, then the time cumplexity to

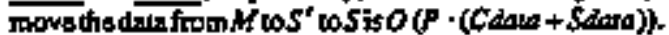

\section{4,3,4Reallocaling Tempotary Dale}

Register usage in $S_{,} S^{\prime}$, and $\boldsymbol{H}$ may differ sigrifteantly from tach orher. The rengon for thts is that on an SDMD arabine, some iegisters exist on the CU and others on the FEs, The registess on the $C J$ afe not used for poly variable operations. On the SPMD waztine, all tegisters are on the PEs and uhus any register can be used forpoly or nowno vartable operations. It is possible to have the VPL compites store, in the ART, eemporary memory locacion and register

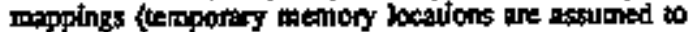
exist in globsl memxiny and not î the sack). A complier reops tratk of the throcmarion slored in registers and tern. porary memory tocitions as ilgenetales and optimizescode [1], and could ereode the rolevarit pars of uhis finfomition In the ART of all the programs. This information could then beused by $H_{M}$ on mop the ralues stored in registers and tem.

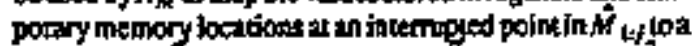

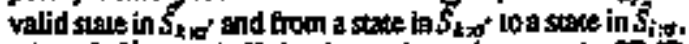
where $\$ S^{\prime}$, and $H$ officienuly we he regiters on the $S A M D$ machine and SPMD mitchithe. Fowever, if some deares of revister wape emulation is done in ather $S$ aed M, simple mappingsmay oxist.

As staled in Suction 2, the \$IMD machine has Creg registers on the CU and Sreg ttigisters on the FEs. Furtier-

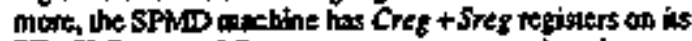
PEs. If Crew and Steme temporary memory locations are usect for now in and pory vareables, tespectively, the ums complexty in perform the terister silpcation is $O(P$, (Cres + Ciensp + Sreq + Stemp) ). This ts the Ime io move the refigiter and temporary dala behween machines, and does not inclede the limetodo the mapping benween the
SPMD mpechine's register set and the STMD mochind's nogiste set The mapping Utme is expected is be

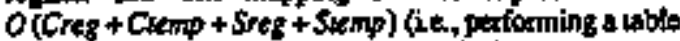
loclap for etchnigister ortemporay value).

\section{SUMBMARY}

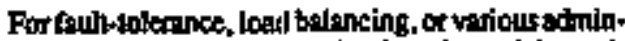
itritive reacons, a lask may nood to be trigribed dyuamically between in SMMD wirugl machitie and in SPMTP vir. thal machine, The mapping, $H_{N}$, from a invemupted point in an SPMD program to \& viable store in an SDID program was pesenled and the asrippote time complexity was given. One of the assumptions madic was that the taste is be migrated was coded in a mote-iodependent programming

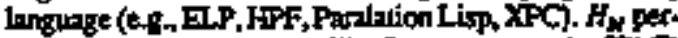
forms a two step mopping, the firs step maps the SPMD program to a somethax iactiocienlintermodizte SDYD pro.

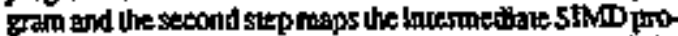
gram in a Bnal STMD program. The introdoction of the

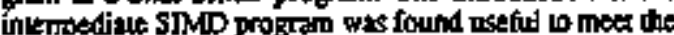
reguirement that when dis SPAD program is incerspted, it is moved "quicidy" off the SPMD machine. The sates of the PAs ars syathronized by the tniermedints SMD progam betcose the ind SDM program is imvoked.

To limit the scope of this peopr jt was assumed thrt the hardware confituration of the SIMD vimual machins and SPMD virusl machine differts only to suppont the diftereat aodes of parallelism. Alhoogh this is not the case for most existine STMD and SPMD machins pairs, the asomplion is appoptiate for mixed-rxodemichines fe.g. OPSLLA, PASM, TRAC. Triton/l). However, the god of the pesper is to solve zent of the more genefal problem of tigigating a esik belween two artitrary SIMD and SPMD mehines. This is sten as a necensty step in solving this more geseral problem in the field of hererdgeneons compuling.

\section{REFERENCES}

(1) A. V. Aho, R. Sechi, and J. D. Utman, Compliters: Principles, Technigues, and Tools, Addison-Wesity. Reading. MA, 1986.

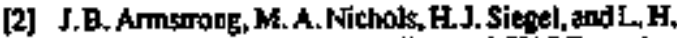
Jentecon, "Exmining the eltects of CD/PE overlap and syntwicnization ovethesd when usiog the compleie sums appeoach is ingage cotrutation," Third IEEE Symp, Forollel and Dturibued Processing. Dec. 1991 ,pp. 24-232.

[3] S. B. Amsinang, H.J, Siegel, W.E. Cohen, M. Tan, H. G. Dise, and J. A. B. Fordes, Dynamic Tatk,Migration Benwen SMD and SPMD Hachinas; $A$ Firs Siep. Tech. Rep_EE Sehool, hurdue, fa preparntion.

[4] 5. B. Armstronk, D. W. Watsor, and H. J. Siegel, "Soltware issues tor the PASM paraltel proetssing system." in Sofnwere for Parallet Computation, eds. Jomuz S. Kowalik and Lucio Girandinetri, SpringetVerlag, Berlin, 1993, pp: \$34-148. 


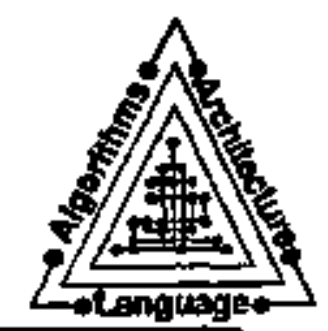

[J] D.J.Brisy andJ.A. Padget, "Towris a viturd multi* computer," Workthop on Haterageneaus Procets ing. A Ar, 1993.pp. 71.76.

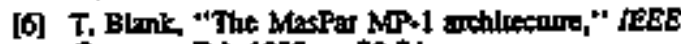
Compeon,Feb.1990,pp.20-24.

[7] E. C. Bronson, T. L. Crasrant and L. H. Jamiesoth "Experinenta] applicatan-triven achiverme

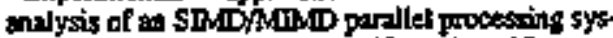
tem," IEtse Trons. Faralki aud Distributed Syaterts. Vol. 1,Apr. 1990,pp. 195-205.

[8] H. G. Diter and G. Krishnomurtiny, "Mese-Sace

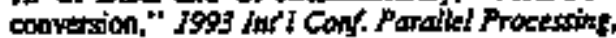
Voln, Aug. 1993,pp,47-56.

[9] P. Doclo6, F. Bosi, M. Auguin, and G. Girindon,

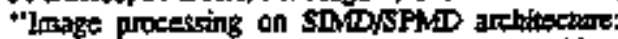

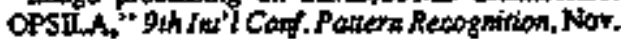
1988,pp.430-433.

(10) E. E. Datach, R. M Rupherford, and C. M. Shab, "Process-originated mijpation in a belcrogtneouss envitcriment" ACM Conf. Compuer Sciesce, Feb. $1989,79,988-102$.

[1]] R. F. Freund and H. J. Siegel, 'Gowi edilors' introduction: heterogeneous pucesshing," IEEE Camputer, VoL 26, No,6,Jane, J993,pp. J3-17.

[12] J.P.Hiyes and T. Mudge, "Fypercube supertomputex." Proc. of the JEEE, vol. J7. No. 12, Dec. 1989, Dp. 1829-1841.

[13] W, D. Fillts and Lewis W. Tucter, "The CM-SConpextion Machtine: a scatsble sopercompites," Cawmanifortions of the ACM, Vot. 36, No. 11, Nov, 1993. क. $30-40$.

[14) Y. Foit?ondor and O. M. SIlbeman, "A mechanism for the mitgralion of casks in hererogepeous distribeted processing systenss," Int'I Couf. Parallel Processing andapplications, Sept, 1988, pp.93-98.

[15] High Performance Forran Furum, "Drrift: high per. torratance Fortran language spectifeacion," High Performence Forman Forwn, Sep. 1992.

[16] Kendall Square Recearth, Techuted Sommery, Ken. dallSquart Reseinch, Wahbom, MA, 1992.

[17] R. Keryet] and N. Paris, "Aesivity counter: new optimization for the dynamic scheduling at SMD conoral flow," 1993 ha' I Cas Poratiel Procersing. Vol. H, Allg. 1993.9p. 184-187.

[18] O. I. Liporsti and M. Malek, Porallel Compuring: Theory and Comparisons, Jotw Wilsy \& Sons, New York,NY, $19 B 7$.

[19] Maspar Computer Corponation, Mas'or MPL Manw als, Masiar Corporzition, Sonnyrale, CA,July 1999.
[20] M A. Niebols, fi. J. Siegel, and th. O, Diez, "Dats managemenl and controlofiow expecs of an STMDSPMD paralled labsuage feomptler," IEEE Troust Parallet and Distributed Systems, Vol. 4, No. 2.pp.222.234.

[21] M.J. Futitipand H. G. Dier. "Towad semantic selfconsistency in explitotly pariles languages," Athinr'J Conf. Supercortpwing, May 1989,pp.398-407.

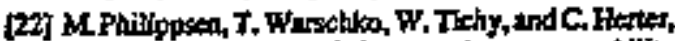
"Project Trion: vowerds imjtowal poogrammabiliny

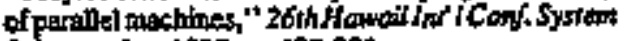
Sedences, Jan. 1995, kp. 192-201.

(23) C. M. Shub, "Narive tode process-origineled nigraton in a sucrogepeous environgent" ACM Eighteren Ambol Cowpuner Science Conf.. Feb. $1990,10,266-270$.

24] H. J. Sleget, I. B. Armstrong, and D. W. Watson, "Mapping engrpuler-tition-relayed nsks onto reonfiturble parallel-processing systems," JEEE Computr, Vol.25,No. 2, Feb.1992, pp. 54+63.

[25] H. J. Siege1, T. Shwetergiti, W. G. Nadion, I. B. Asmsuropg, L. Wang, J. T. Kushn, R. Gupt, M. D. Allemans, and D, G. Meyer, "The destegr and prowo. typins of the PASM roconfigmalte parallet processing system," in Parallet Compating Paradigats and Appilicenions, Atber Zomays, ed., Chopman and Fall. Londion, UK, 1994 (inpecss).

(26) J.M. Smith, "A strvey of process mifaction mechanism5," Operating Systent Rentew, Vod. 22, No. 3, July t988,pp, $28-40$.

[27) M. M. Theimer, K, A. Lamb, and D. R. Cherion. "Preempable remote extecution facillites for the V. Syotemm," Tanth ACU Syatp. an Operating Systems Principles,Dec. I985, pe.2-12.

[28] 1. W. Tucket and G, G. Rabertson, "Archileswre and applicalians of the Connection Machine" IEEE Compwer, Vol. 21,No.8,Aug. 1988, pp. 26-38.

[29] D. G. Von Bank, C. M. Shab, and R. W. Sebesk A Untited Modet of Paindise Equivalence of Pro. etedurel Compotorions. Tech Report TR.pE EASCS-93-3. Computes Sctence Deparment, Universsicy of Colorado, Afr. 1993.

[30] D. W. Waton, H. J. 5teget, J. K. Antonio, M. A. Ningks, and M. J. Atrltab, "A tramework for compile-time selection of peritel modes in in SIMD/SPMD heverogeneous envitonment," Workhop on Helerageneous Procossing, Apr. I993. pp.57-64. 


\title{
LOOKING UNDER THE HOOD WHILE DRIVING THE INFORMATION HIGHWAY
}

\author{
Ed Krol, University of Illinois
}

Id like to talk about the Intemec todry. My approach will be to tell you a bit about what it is, how its structured and how to use ic, but at each point also give you a hand waying explansion of how it works as well. It tarns oul it may be big but lie concepts betind it are pretry sunightronward.

The Internet is a large number, over 29000 , of networks who bave all agreed to use the same basic techmology and carry exch others traffic. For the end user, this means that if you are connected to any one of those netwoiks, you have arcess to computational and data resources on any of the others.

Thene is no central control or chief operating officer of the Internet. Each networt is independently nu. In its original incarnation if a netwots warted to become part of the Intemer, it would be connecied over a dedicated data communications line. Routers, networking nodes on the joiting network wonlf sendd a message to the closest neighbor. saying that it lnew bow to get to and would act as an agent for a list of new networks. The neighbor would pass this infortuation on tritil fairly quickly, the entire net would know how to reach those new networks.

This model bas a number of consequences, the most basic is that we have know idea exactly how many people or conputers there are on the Internet When a network joins the Internet il can be counied, but the owner of that network did not have to register or ask permission to add any of the computers on il. Each of those computers may service any number of people, again we don't know how many. Estimates of these pumbers ron about 2 million nachines and 20 million peopte-

The growh of the Intemet has led to a slight change in this model for foute acquisition. Consider the problem, what if a pet tells jis nejghtoor th can reach a network bet it really can't? In this sifuation, comminications destined for the orphaned network pour into the nelwork claiming a commection and they are lost. To get around this ptoblem, many of the major cransit netwoiks of the Inturoel maintain a believability database, which says which announcements should be believed when received by the transit network.

So we have this odd network of networks with no one in charge, what are the properties which raakes it special? One major property is that it is peet to peer. Every conputer on the Intemet can either be a consumer of a provider of resoerces. This allows resources to be toade avaihatle for really small cliestele, with no necessity for their economic viability or profit potential.

The second property is that what is provided is a commanications perbway. with all the smarts in the peer machines. This allows the end machines to do experinental things and in fact improve over time. Alt it takes is new saftwate and there is new functionality.

To understand bow these peer machines contrumitate, consider the globat postal service. It's an internet, too. You can send a message from the US to France without ever knowing the underlying transport. This works becanse the postal services have apred to act as each others agents, agneed on a standard forrat for handiling mail, and will pass messages closer to a destination even if there is no direct routh.

The Integlet is the same. The agneernent is the Intemea Protocol (P) which specifies the format of an envelope for a shor packet of data, usually less than 1500 bytes, and an 
address fomrat An applicatuon on a computer nerely has in put fis message in one of these packets and address it correcty. The Internet will take it and atteropt to get it to its destimation.

Of course we all know the stereotypical stories stopt the post office being an unrebiable delivery mexbanism. The design criteria for the Internet assumes the same. Al any time an IP packet might get losh, or dietivered ou of sequence. A basic IP network is apt a particularly useful cormaunications tool

To fix this, the Ttanswission Control Prolocol (ICP) is usually run between the application and the IP network It assures that data is presented in the sante order to the receiver as it is sent, and that all missing or comupted packets are neiransmitted. So 10gether TCPTP gets you a reliable byte strean between any two Interned connected computers in the wordd.

Most people don't get endhused by reliable byte streams - they want to do real work or real science. Doing real work on the Inleistet involves clients and servers. Clients are piects of software which are manipulated by a human to do something useful. If necessary clients contact servers across the pet to provide them with resources reguired to do the furmats bidding. Everything on the Internet happens in this manner. And. one of the benefits of this type of computing, is that the server can handle reguests ftom a vartety of platforms.

In the late 60's or early 70's the origtnal applications on the Internel were harmmered out. These wene electrosic mail, remote login (cistesinaring across the Intemet), and file transfer. As was typical of the time, before grophical user inlerfaces and mise became popular, these application were cornmand line driven.

This is where the linternet's developinent faltered. The first problem encoumtered bos been finding the resource to access. In its earlier days, the major means of funding resonices, was human networking to support the Internet. People would go to confenences and meetings, hess about good things, and write down thetr location. When they returned home, they could use their new found information to access what was there.

This is where the ocher miscue occured. Since a client program had to be written for each piationm used, developers could have designed it use the command structure of the local machine wherever posslble. This would have allowed the users knowledge to be applied to its new found tasks. Rather, they wrote a set of global commands for the Internet applications. Even if you were quite compelent on a TOPS-10, Unix, or an IBM machine, you had to leam "fip" to use the retwork. It kept people from trytsg.

Its only been reently that this trend has reversed. Now we are starting to see clients, which use the intrinsic characteristics of uhe spectfic computer to io networt access. This mears that anyone competent on a Macintosh, or Microsoft windows taachine, can use the Internet in a manner dtar they are familiar with.

Another trend we see in the development of new applications is a move to integrate just like the evolution that occurred in the PC world. The PC staned as something that could run BASIC. Next, people developed word propessors, spreadsheets, and graphics packages. You could write your texh, do your calculations, and rake grapis. You would then have to print thern all out, cut and paste them with real scissors and paste. Now, there are integrated packages that allow you to do all of those things and print a finished product

The sarne thing is happening on the Intenet. We started with a bunch of discrete low level tools and have worked our way up to tools which allow you to find a resource and say give 


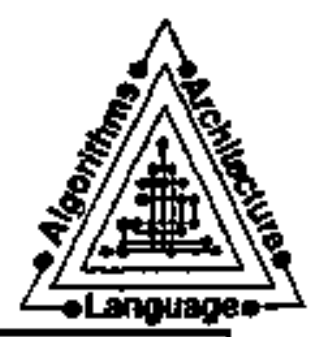

me that, and it appears. Interestingly enough, these new tools were so simpte in concept that they took forever to be developed.

The first of these tools which brought the Intemet out of the reatm of computer geek and atlowed its use by the common computer literate person was gopher. Gopher is a ment oriented tool for deliwering grimarily tex! files. It started out as a campus informacion system at the University of Minnesole. In the course of ahout 3 years it las gone from ane site to well over 1000 servers.

A gopher client presents to the user menus. This is a sereen from Tuzbogopher on a Macintosh, but it doesn't mattec. You could have accessed the same data froto just

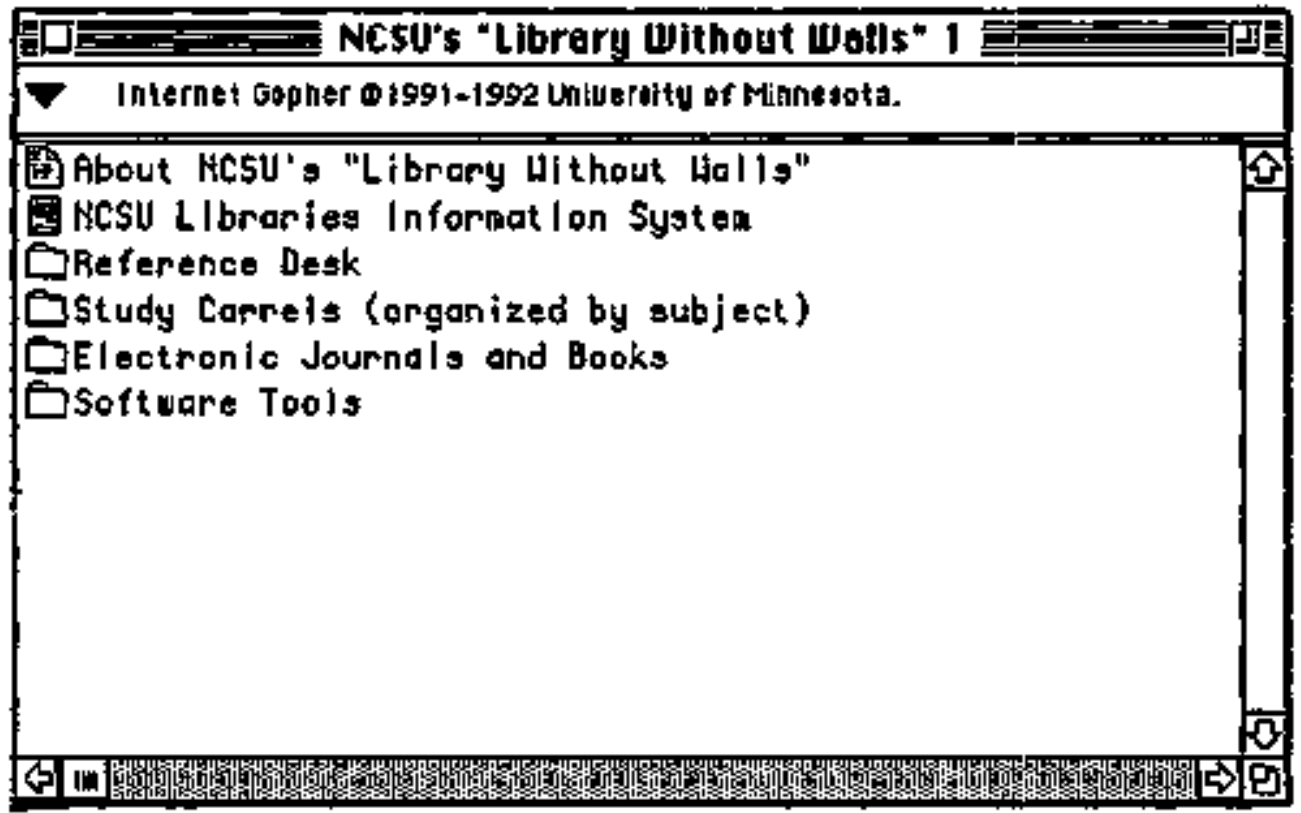

about any type of machine, including those with non-graphical displays. Notice that every tine has a type icon to its left. The documents are documents - if you click on that you will see the document. The folders are sub-menus - click one of them and another toenu appears. The computer icon is a timesharing resource. If you select it gopber wil] aviornatically stmole login to that resource.

How does this all work? Notice the similarity between a gopher serwer 's menu structure and a file structure. A menu is sirolar to a direcloty and files are files. In fact that's the inplementation. You nun server software on a computer somewhere and point it at a file structure. The one inleresing twiss is that it by default tisplays filentames and ditectories as menu ilems, but if you define a "tiltes" file it will substitute a human readable tite for a filename.

Name-Study Carels (organized by subject)

Type=1

Port $=70$

Pathelijorar/disciplines 


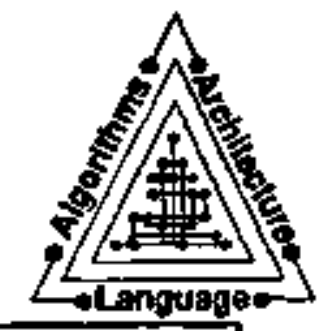

Host=dewey.libscsu.edu

There is no long term relationshjp between a gopher client and a particular server. Wher you access a server it sends your client a menu and some hidden data which tells your client how to scess the each item. That itern may be served from the same or another server it doess'l toatter. When you choose another ien, your client vill contact the host specified on the port specified, and ask for the path. This will return sonething to be displayed depenaing on the type.

That's how gopher works, but the engineering push for simplicity aiso limited its high end capabilities. The data displayed is a file of some type, nomally text or a GIF image. This makes it quite easy' to taake documents available, boc there is no real way to have inbedded itoages and other types presenti problems.

The alternative to gopher is to choose the higher end, but more maintenance intensive technology of the world wide web. It has been around longer than gopher but has always suffered, because the document preparation time was grealer for litte payback. The refomlating effort necessary to add hypertext links to olher docundenis was just not worth it since whal you got end looked a tot like gopher. This leck of payback was doe to there being no good display clients. With the advent of a client called Mosaic this has all changed. Mosaic, from NCSA, is the best of the WWW browsers around. Allowing multimedia presentacion of audio, pictures, video, and text in a complene package.

Web documents are prepared and stored in an SGML derived markup langoage call Hypertext Markup Language (HTML). When a client nequests a document it is returned in raw form and formatted by the client. This allows the cliest to do formatitis in the best possibie marner for the display provided.

This is a tisplay from Mosaic for a Macintosh (there are $\mathrm{X}$ and Microsofl windaws clients as well). Notice the variely of ext fotnals and the thumbrail stzed jnage. This trmage is displayed and should the user wanl wo pay the time to get a foll sized higher resolution image il can be fetcheof by clicking on it 


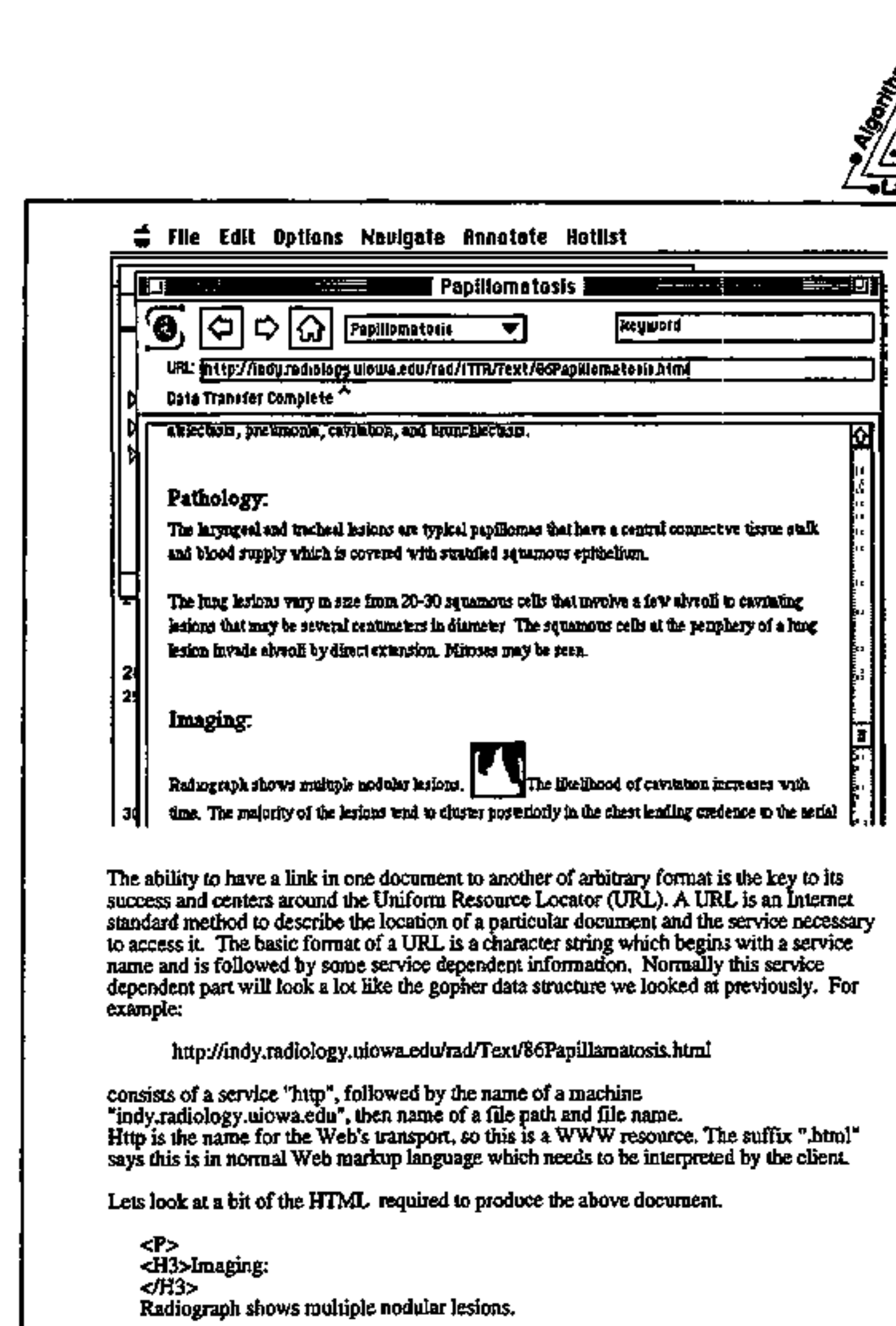




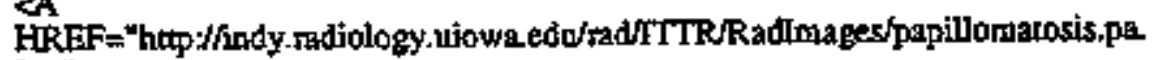
jPg">

\section{$\checkmark \mathrm{MMO}$}

SRC="hntp/londy, radiology.uiowhedu/radiTTTR/Radlmagesjpapillonatosis.paic on.gif"s

$\angle A>T$ The itrelihood of cavitadion increases with time. The majority of the lesions tend to cluster posteriorly in the chest lending credence to the aerial dissemination theory.

This section of document starts with a paragraph marker ( $<P)$. Then it puts out 2 level 3 section header beginning with $\mathrm{CH} 3\rangle$ and ending with a $\langle\mathrm{H} 3\rangle$. There is some tanton text followed by some pointers to other documents berween the $\angle A>$ and $\langle A\rangle$. The string beginning with HREF is a URL convection to anothes documlent $f($ conld be text, audio or a picture. This happens to be a JPEG graphics image (the ending ".jpg"). The inline thutabnail inage is located through the URL following the $\angle M M O S$ SRC... directive. After the $\angle / A>$ follows some nompal text again.

So now we see bow the Internet hangs together and how you might use it. Now lets think a little about the challenges facing it first, the techtnology is neat, but peopic don't really know how to apply it They are applying fi inappropriately by trial and error, typically building a worse mousetrap. If you consider the medical nesource early, ask yourself why they should builo that. They are producing a medical exibook which can only be read while you are seated al a conpected computer. If you want io study at the beach, you can oniy do it for 2 bours and lose significant resolution. Granted the texthology will inprove, bul at this point its a waste of time.

Correnly, we are in the trial and erfor phase of deploying Web technology. Not only don't we know when it should be deployed, but the actual format of these documents is also being hammered out Currently authors don't really know whien and bow to include inages or when to include líns to olher resources. Many web documents have so many links iss like reading a magazine article with lots of side bars - there is no obvious way to proceed through it. The course will become more apparent as more documents get writlen, read, and critiqueas.

Another problem we have is that the culture is biased against onlinte resources. Libraries woik pretry pootly, bus ahey are tolerated. If you look up a book in she card catalog, and then proceed to the sbelf and dan't find it - you were unlucky. If you find a network resource and try to connect but can't access it - the network doesn't work.

People forget about how to do research in an online environment. Traditionaliy, if you need to kenm sbout a new topic one of the ways of doing it is to get one article and look at the reterences. That method works on the net too, especially in the WWW. If people find one document they like, it will usually have livks to others. People just refuse to do the old stuff in a metworked environment

Thent is also a problem with citability of onlime resource. How do I know the avthor is authoritative and bow do I know a work has not been and will not be altered after it has been cited? This is purely a tectunological problem, solved by deploying digital signatures.

Finally, there is support inertia. As the Intemet grows larger and larger, it gets harder and harder to do both support and experimentation. You need to sBctifice technological solutions in deference to the installed base. And, you might neod to slow deployment of 


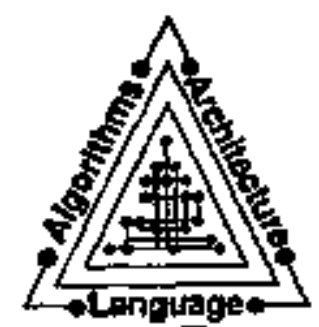

new technology because having many versions deployed leads to too mech of a support problem. This in facl will culbinate when the NII ts deployed because the software will probably be locked in silicon.

In conclusion, the Intemet is a communication pipe usable for whatever you want. There are standard things to do, but you can use it to do any kind of buman collaboration or conputer coltaboration you can imagine. 


\section{INTERNET DEMO}

Tom DeBonl, LLNL, and Dale Land, LANL

\section{The Internet: \\ "Takin' her out for a spin around the block"}

\section{define: Internet}

The Internet is a Global interconnection of some 30,000 separate, autonomous nel,works. Many of these networks are outside the Appropriate Use Policies as set forth by the US Government. There are no uniform laws that direct use and misuse.

The Internet Society has been given stewardship responsibilities for this Global Internet.

Your mileage may vary. 


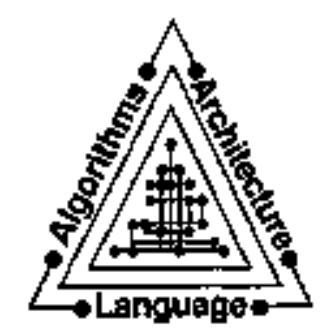

\section{The Scenery}

- Basic Functionality

- Remote login, file transfer, remote process communication .

- Services and Servers

- E-mail, FTP, USENET Nows

- Information retrieval agents

- Copher, WAIS, Archle, WWW and hypermedia.

- The "Killer" application

- Mosaic

- Inter-human communication

- Multicast; NV, VAT, and WE

\section{Basic Functionality}

- Remote login

- Virtual terminal sessions with non-local computer

- File transfer

- Machine to machine file copy

- The beginning of moving information, not people

- Remote process communication

- Fundamental for all uses to come

- Bujlding block of higher level services 


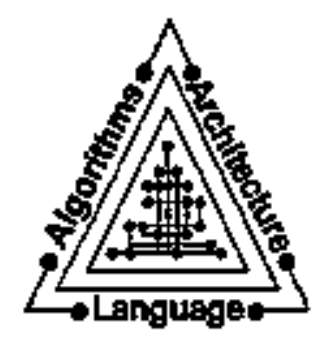

\section{Services and Servers}

- E-mail

- Asynchronous person to [one, some, many]

- Straight text initially, MIME to the rescue!

- FTP

- Scalable, low-cost Information distribution

- USENET News

- Thousands of globel bulletin boards

- Over 6000 subject areas

- Inflnite time sync for the undiscipllned

- Open ended technical advice from experts

\section{Information Retrieval Agents}

- Gopher

- FiP cllentserver palr

- Stateless - less impact on server

- Vtsual - more impect on the user

- Archie

- Filename search service - use it to find whtch servers have named files.

- Database built by automatic monthly combing through anonymous FTP servers on the Internet.

- Queries to Archie are searched in Its database

- Querlable by Telnet or E-mall. 


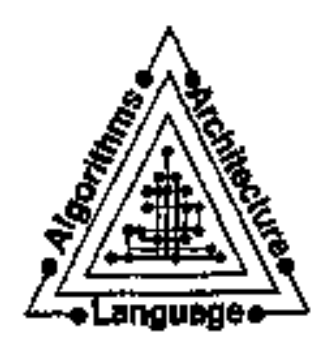

\section{Information Retrieval Agents}

- Wide Area Information Systems (WAIS)

- Content addressable FTP server search sarvice

- Invented by TMC.

- General keyword searches of servers and their directories.

- World Wide Web (WWW) and hypermedia.

- Integrates all of the above services.

- WWW protocol defined at CERN

- Hypertext + Multimedia = Hypermedia

n Hypertext - semantic network overtaid on linear text

2 Multimedia - multi-modal data delivery

\section{The "Killer" Application Mosaic}

- Developed by NCSA - freeware

- Available on MAC, UNIX / X11, PC platforms

- Implements WWW protocols with pleasing user interface

- Provides common interface to FTP, telnet, gopher, USENET News, and multimedia applications

- Responsible for large jump in internet traffic

- Home pages are appearing with increasing frequency -or- more info available daily

- Demo (with any luck at all....) 


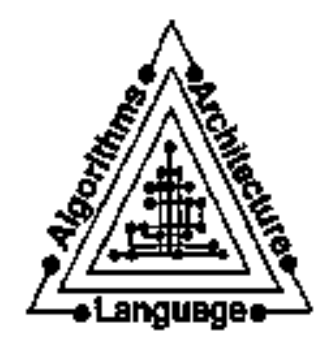

\section{Inter-human Communication}

Teleconferencing and Telecollaboration

- Network Video (WV), V Audlo Tool (VAT), Whilaboard (WB)

- Developed by Van Jacobson al LeL

- These tools used in concert provide a glimpes linto the tuture of Nill based human communication.

- Network TV (example - Los Alamos broadcasta to the Internet Clinton's vistt there)i vlewed on SPARGsidiolions at LLNL

- Imternet Ratio uses this medium - also avalable for FTP using torementioned technologles

- Mulftcast (IP)

- Foundetlon for above technologies

- Broddcast llke radlo - you "tune in" to an IP addrass

\section{Aside}

- Comblnet bridges are a good solution to the "last mile problem"

- Pre-requisite: switched Digital or ISDN service must be available in your area to make use of this technology

- Bridges two Ethernets across digital phone lines

- 2 besic flavors -

- ISDN Baslc Pate Interface uses bandwidth of both B-channels (64 kbps each)

- switched 56 lines uses bandwidth of one or two 56 kbps fines

- Costs "about as much" as a modern

- Offers 5 to 10 times the bandwidth

- In active use at LLML 


\section{ATOMIC/MYRINET - A NEW GIGABIT LAN TECHNOLOGY}

Danny Cohen, Myricom, Inc.

\section{Overview}

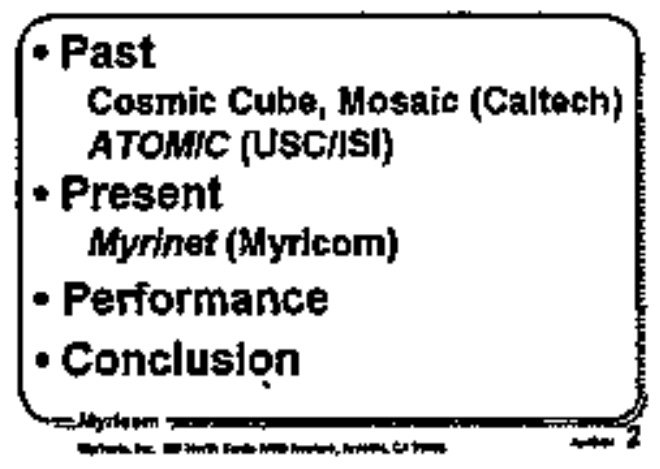

Seitz's Cosmic Cube

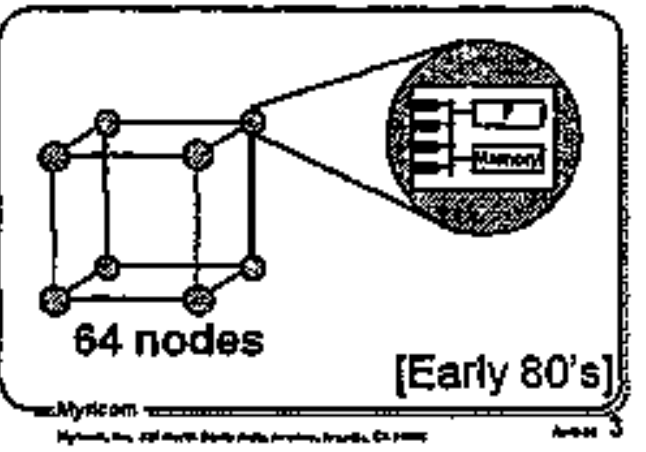

Mosaic Communication

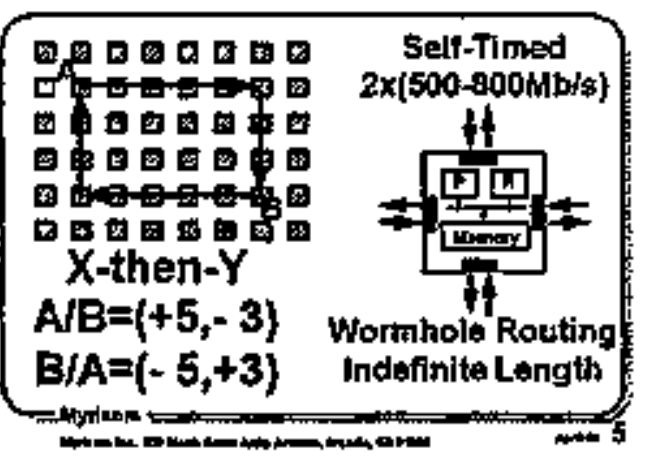

Seitz's Mosaic

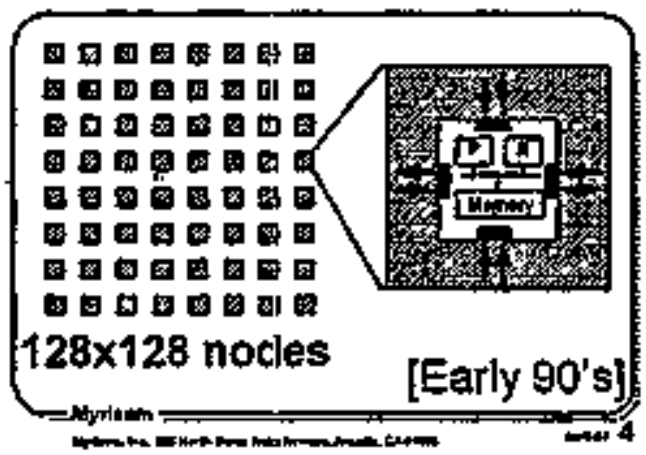

\section{Distributed Comm'n}

Mosaic uses a totally distributed communication, both for routing (by using stateless switches] and tor data transter.

Speed implies Stateless;

Stateless implies source Routing. 


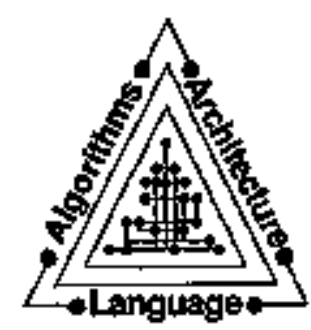

\section{USCASI'S ATOMIC}

\section{ATOMUC is an extension (and} expansion) of the Mosaic internal multicomputer communication, with performance similar to that of system buses.

\section{Larce "backplane".} not small WANI

שו

\section{ATOMIC's Components}

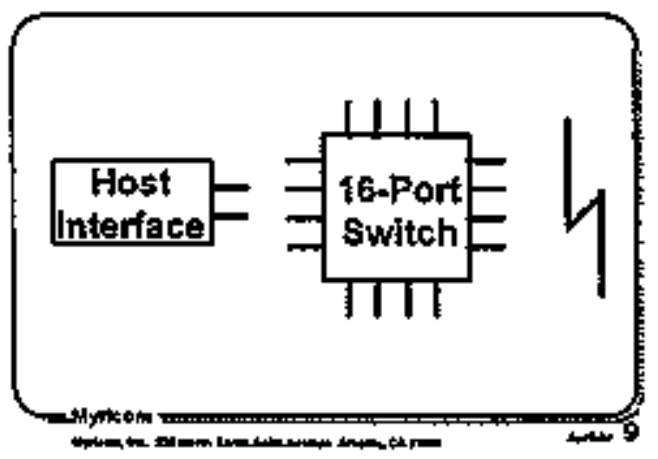

\section{Problems}

1. Topology (incomplete meshes)

2. Longer distances

3. Host interfaces

4. Addressing and Routing

ATOMIC solved these problems

A backplane is not a LAN!
ATOMIC LAN

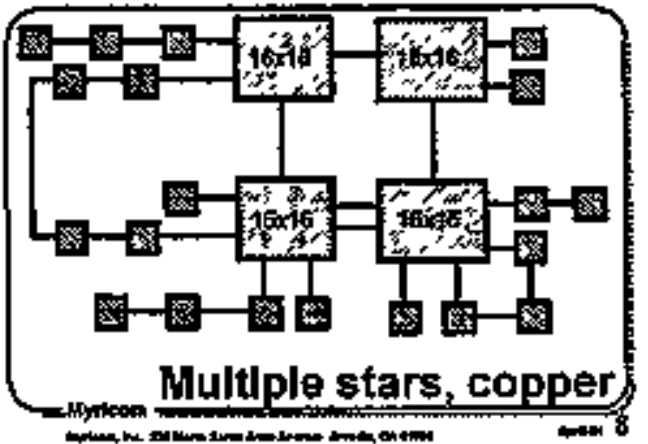

ATOMIC Switches

-000000 ATOHC uses Mosajc

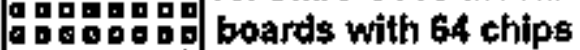

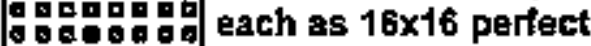
switches or as $32 \times 32$ bowbo blocking switches.

Tha boards are "mass-produced" for the Mosaic multicomputer, and are available at low cost.

\section{Protocol Level}

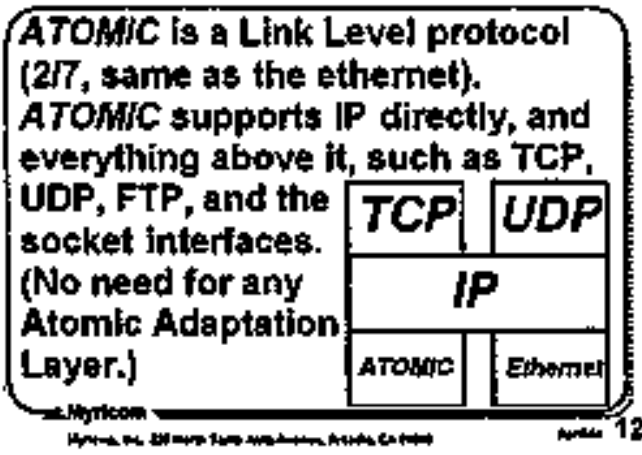




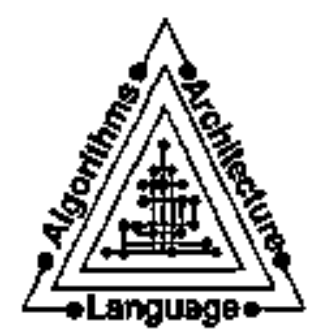

\section{Host Interface}

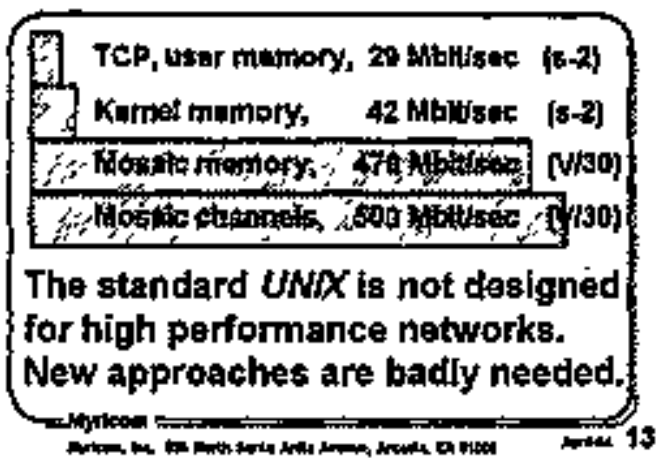

\section{Addressing}

ATOMC doesn't have addresses.
it usess Source-Routes to direct
packets to their destinations.
This allows switches not to have
any routing knowledge, and to
be very simple (simplicity brings
low latency and high dath rate).

\section{Source Routing}

All the knowledge about routing is at the hasts around the network. None is inside the network. All the switching elements operate with the latency of one byte, 18ns (on 500hb/s channels).

\section{Direct Mapping}

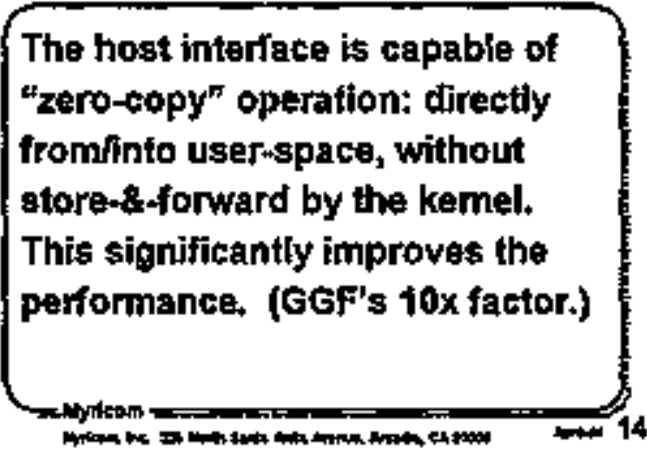

\section{AC: Address Consultant}

- Logically contralized, Iodundant, and fautt-tolerant protess

- Finds the network topology

- Provides Source-Routtes to hosts

- May provide Mos (high load streams)

- Montors health (self healing)

- Supports multicast and broadcast

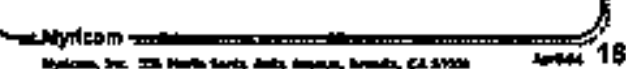

\section{Reflection}

Koeping all the routing information outside the nenwork, in the hosts, does not scale to large networks, but works vary well for limited networks, such as LANs. 


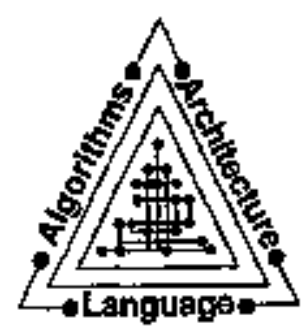

Mosaic Performance

\begin{tabular}{|c|c|c|}
\hline \multicolumn{3}{|c|}{$\begin{array}{c}\text { Single Flow, programmed ISO } \\
\text { VME at } 30 \mathrm{MHz}=480 \mathrm{Mbls}\end{array}$} \\
\hline Bytelpit & Kplatsec & Mbltts \\
\hline 4 & 788 & 25 \\
\hline 54 & 475 & 205 \\
\hline 1,500 & 37 & 450 \\
\hline
\end{tabular}

Switch Comparison

\begin{tabular}{|c|c|c|c|c|}
\hline & Mpits & $\begin{array}{c}\text { latuncy } \\
\text { (ns) }\end{array}$ & $\begin{array}{c}\text { Channe } \\
\text { (Hbls) }\end{array}$ & $\begin{array}{l}\text { Switch } \\
\text { (Gbig) }\end{array}$ \\
\hline AN-1 & 2 & 2,000 & 100 & 1.2 \\
\hline Weclar & 14 & 700 & 100 & 1.6 \\
\hline $\begin{array}{l}\text { ATOMC } \\
\text { (Ex) }\end{array}$ & 31 & 125 & 500 & 1.3 \\
\hline \multicolumn{5}{|c|}{ All measured } \\
\hline
\end{tabular}

\section{Intra-Computer}

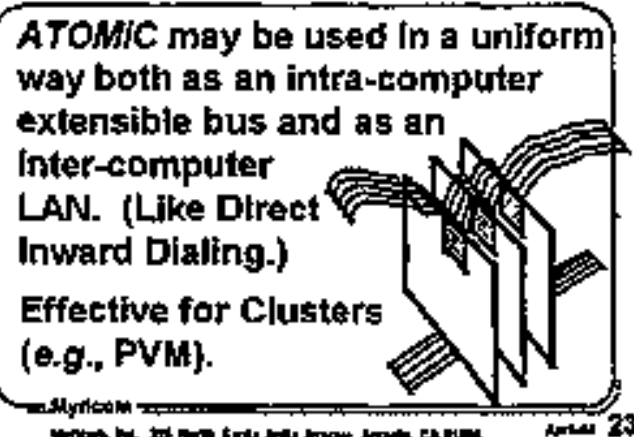

\section{Channel Performance}

Multiple Flows, programmed Iro
VME at 25MHz = 400Mb/s
\begin{tabular}{|c|r|r|r|}
\hline Flows & Bytelpkt & Kpkt/sne & Mbits \\
\hline 8 & 4 & 5,250 & 168 \\
\hline 2 & 54 & 793 & 343 \\
\hline 2 & 1,500 & 39 & 405 \\
\hline
\end{tabular}

\section{Reliability}

Over peta (101-15) bit transfers occurred without a single bit-error or a packet loss.

(p.s., the program was verified)

a the 32

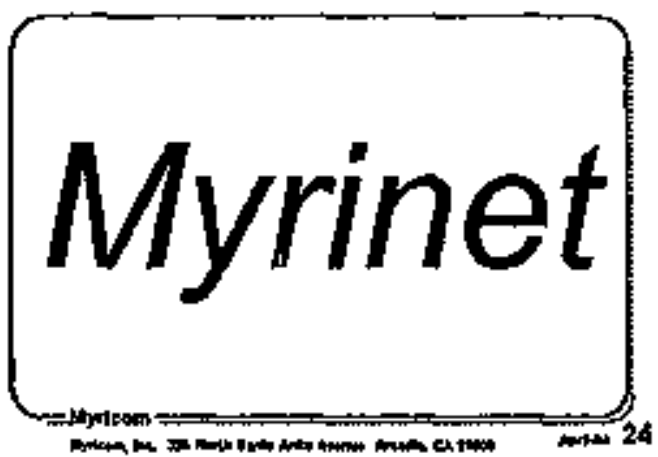




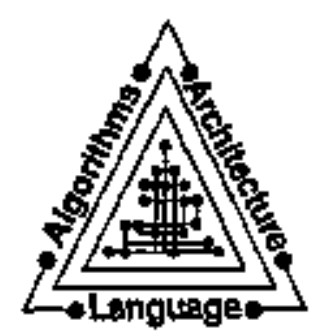

\section{Myrinet}

A refined commerclal version of ATOMNC, bujlt by Myricom.

It uses higher performance components, at about $\$ 1,500$ for a Gigabit host connection (including share of the switeh). Muriner is a fastertsmancer atowe

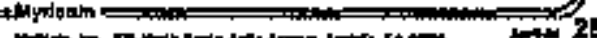

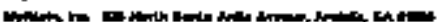

\section{The People - 2}

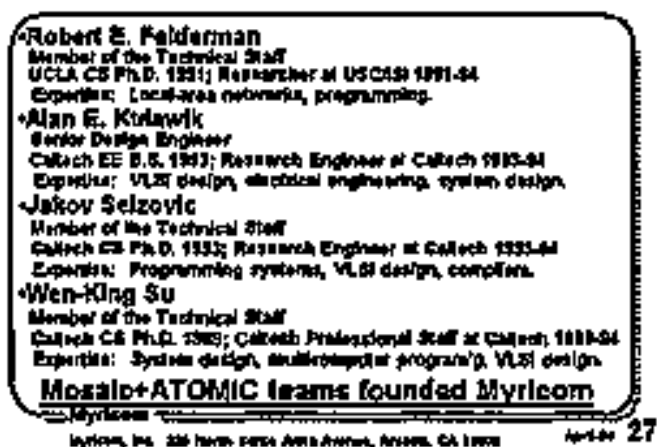

\section{Myrinet}

\section{Myrinet uses more robust} channels sultable for several physical media, coping with $40 \mathrm{~m}$ delay, with CRC on every link.

DMA based, smarter interfaces. Shipping in 6/94.

\section{The People of Myricom}

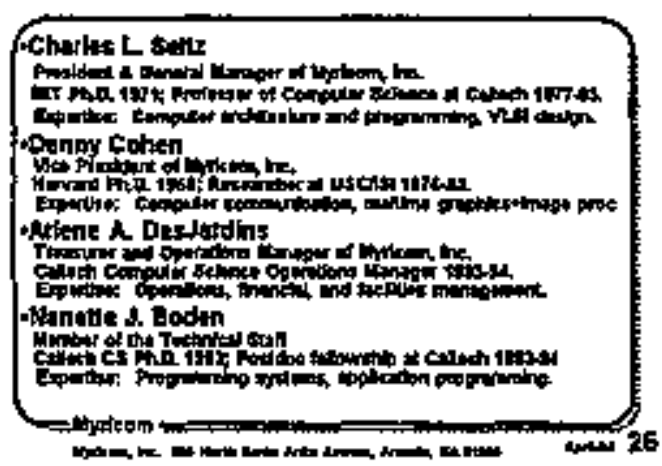

Myrinet, an Example

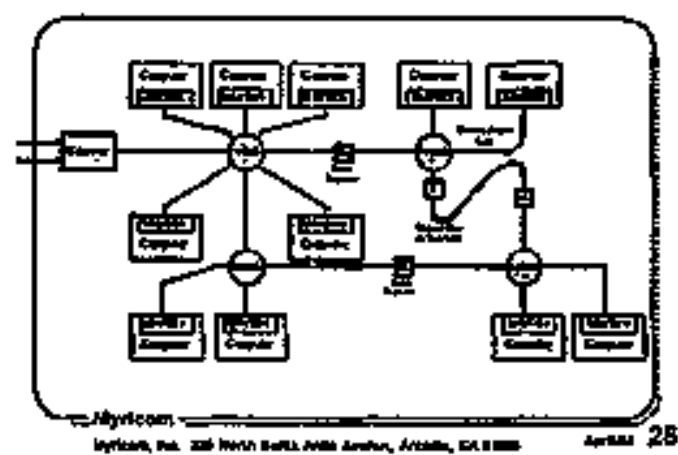

Myrinet Channels

the link protocol is called dialog. Dialog is opentpublic.

9 ieads, for 8-bit data plus control. Startstop hop-by-hop flow control. CRC (cummulative) on every hop. Synch XMT (infext), self-timed RCV. 80Byte FiFO on the RCV side $(40 \mathrm{~m})$ Timeouts and fault detection. 


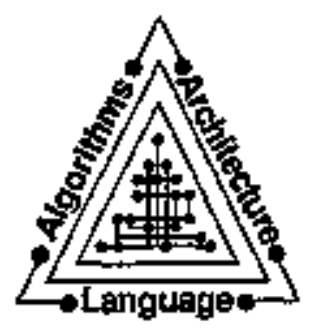

Myrinet and fiber

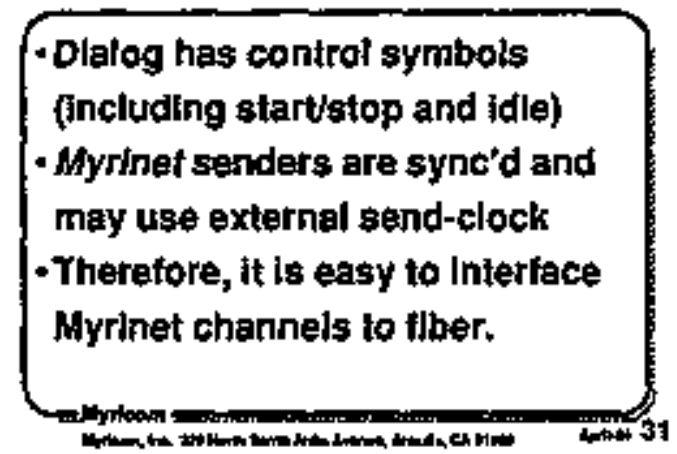

Encapsulation

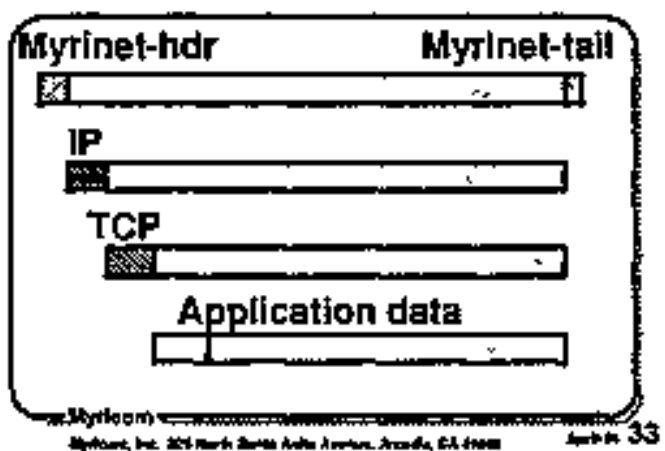

Myrinet Switches - 2

- The switches bave no Internal memory ("stored state").

- One source-route byte selects the out-port.

- Hence, they don't have routing tables that have to be loaded, initlalized, coordinated, verified, and checked.

\section{Protocol Level}

Myrinet is a Link Level protocol (27, same as ethernet+ATONIC). Myrinel supports IP directly, and everything above it, such as TCP, UDP, FTP, and the socket interfaces. (No need for any Afyrinet Adaptation Layor.)

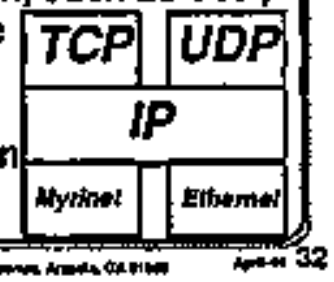

\section{Myrinet Switches - 1}

- Myrinet switches have $4,8,12,16$, ...32 ports.

- Perfect crosshars, wthout any interference among flows (unless they have same destination port). - All ports have fair access (no head-of-the-the priority).
Myrinet Routing

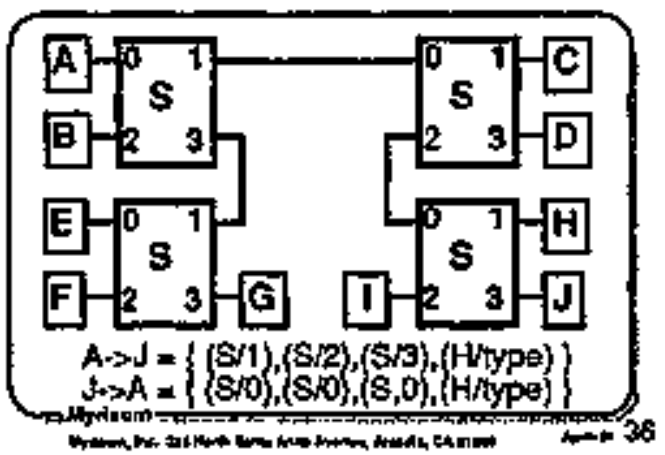




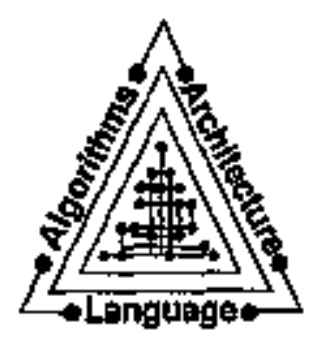

Myrinet 4-Port Switch

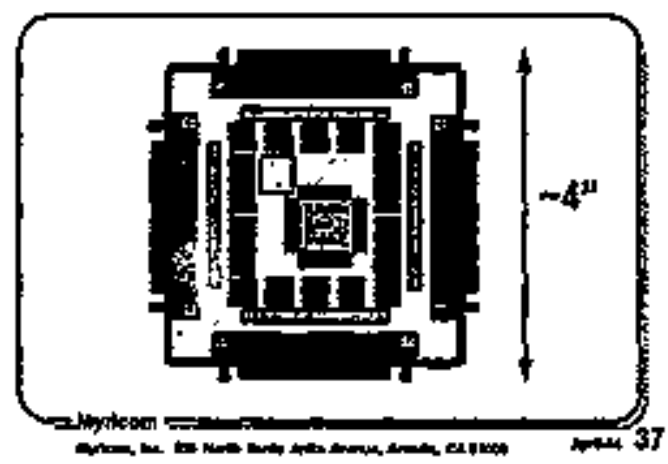

\section{Components}

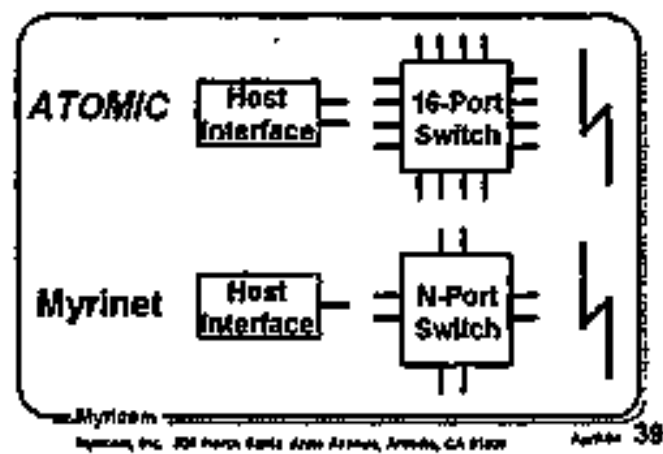

\section{Myrinet Management}

- The Myrinet Route Manager (RM) helps hosts find each other (like ATOMC's AC).

- The RM is clistributed among all the host interfaces on the net.

- The RM uses MIBs to report about the network.

\section{Myrinet Packet}

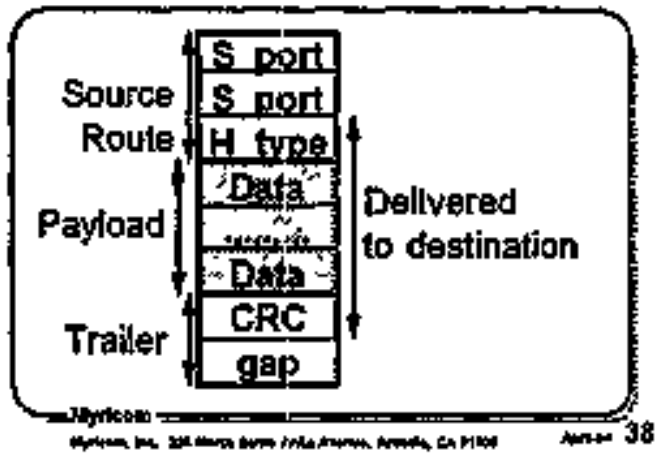

\section{Myrinet vs. ATOMIC}

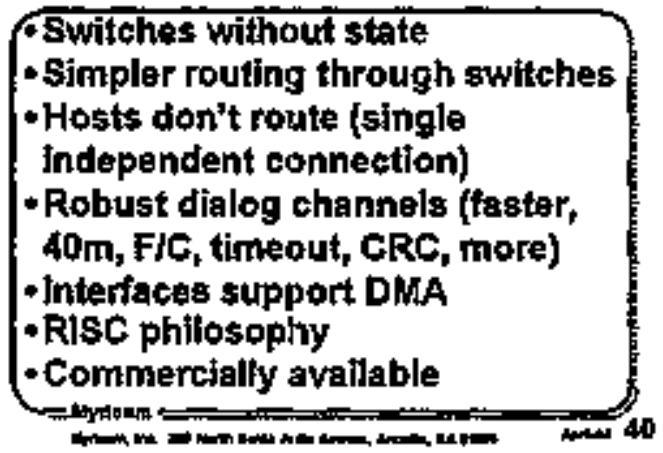

\section{Myrinet Host Interfaces}

- Host interfaces match the host speed to the channels.

- They provide hardware assist for Internet checksums.

- They have DMA capability.

- SBus, SGl, HP, IBM, DEC, VME, $\mathrm{PCl}_{1}, .$. 


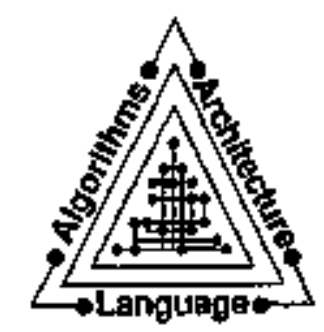

\section{Myrinet/Sbus Interface}
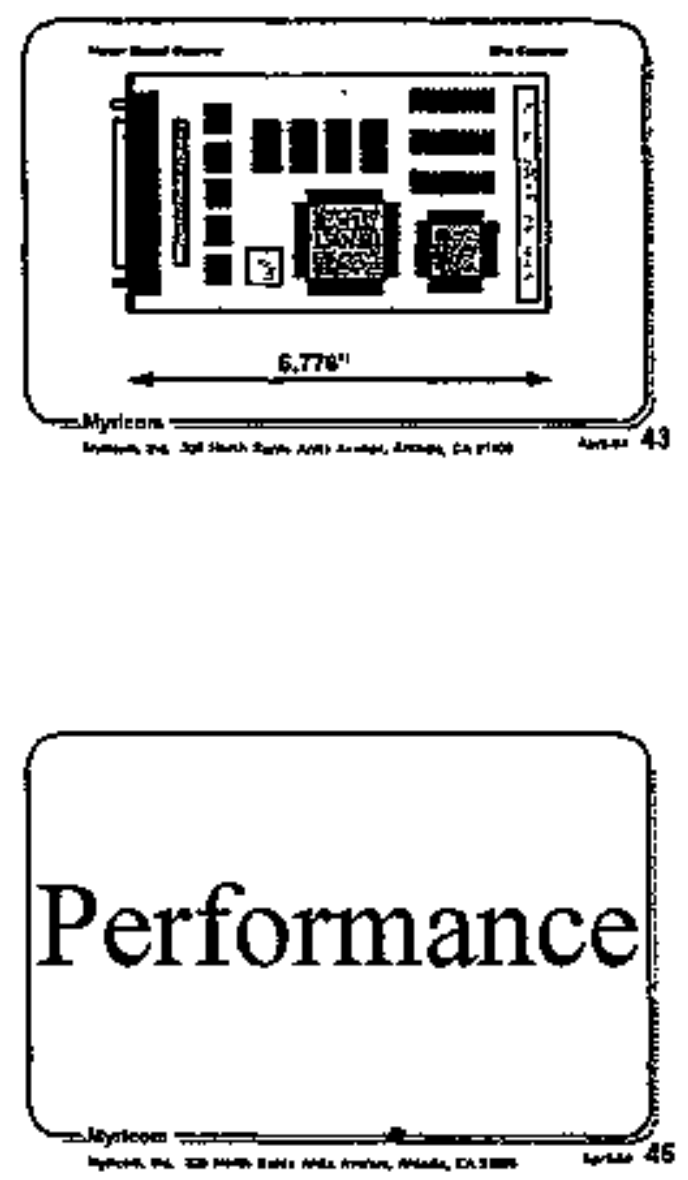

Store-\&-Forward Timeline

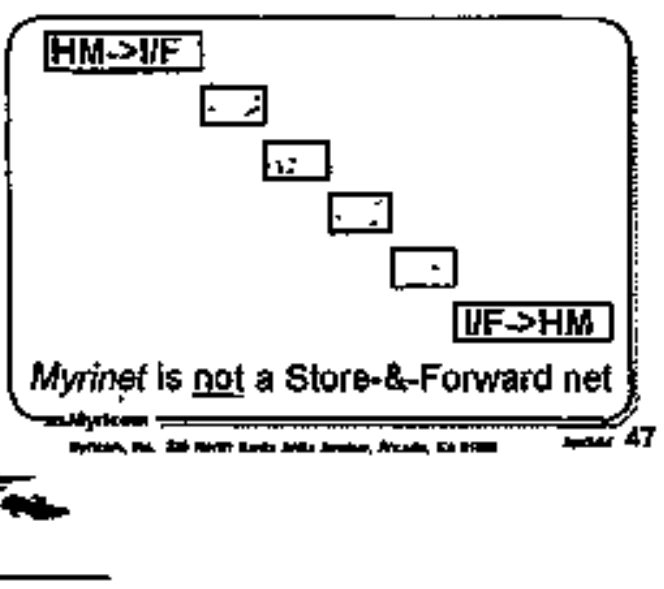

The LANai Chip

Host interfaces uses LANai, a derivative of Mosaic-C, with a RISC processor, packet interface, and interfaces to local and to external memories.

It controls the transfers tolfrom the host's memory and fromito the Myrinet channel.

\section{The News}

\section{Good News:}

Myrinet ls very fast

Bad News:

Host are slower

Goad News:

Myrinet can help the hosts

The hardware problem is solved; but not the software problem.

\section{Cut-through Timeline}

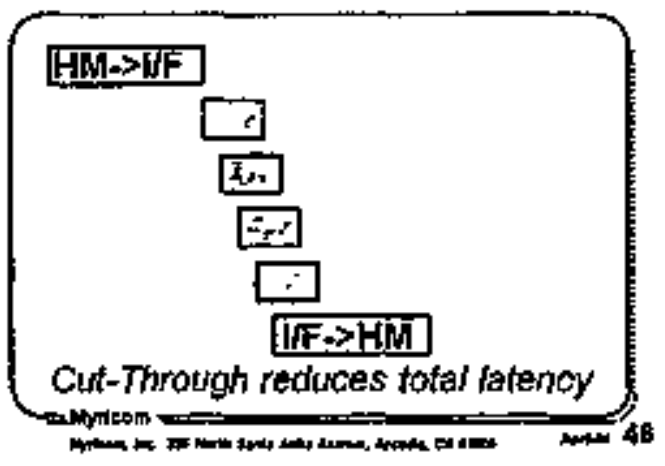




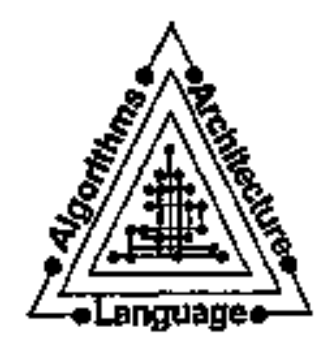

\section{Myrinet timeline}

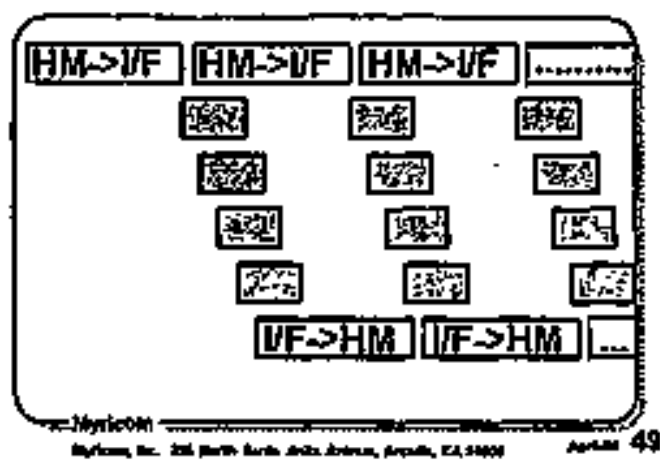

Performance (def'n)

Pertormance depends both on the per-byte and the per-packet processing.

The time to handle a packet of size $L$ is: $T(L)=A+B^{\prime} L$

PacketRate $=\frac{1}{T(L)}$ DataRate $=\frac{L}{T(L)}$

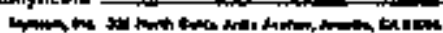

\section{Performance}

The performance of Myrinet is determined by lts channels and by its topology.

Its channels operate at $480 \mathrm{Mb} / \mathrm{s}$, with a latency of less than 30 Byte (500ns) per 8-port switch.

This performance will advance with the sillicon technology.

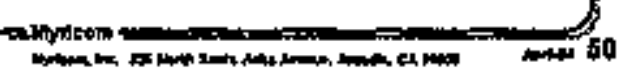

The Bottleneck

When conveylng TCPIIP or UDPIP packets over a Myrinet, the performance bottleneck is definitely the protocol stack as implemented, not as defined (sockets, copies, etc.).

\section{Good News}

We expect our MyrinedsBus
interface, SUnOS device driver,
and modified protocol stack to
achiove end-to-end TCPJIP and
UDPIIP transfer rates of about
150Mb/s with $4 K B$ packets (HTUs)
between the faster Sun models,
such as SPARCstation 10s.

\section{Future Performance}

As faster workstafions become available, the end-to-end TCPJIP and UDPJP transfer rates will creep closer to the $480 \mathrm{Mb} / \mathrm{s}$ Myrinot-channel rate. (The Myrinet channel pertormance is also expected to improve.)

$$
4 B 0 \rightarrow 640>1,250 \rightarrow \ldots
$$




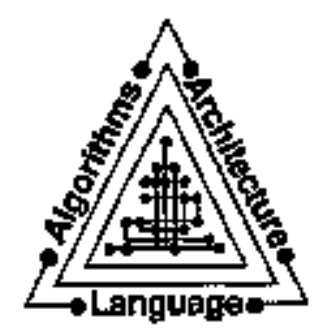

\section{One or Zero Copies?}

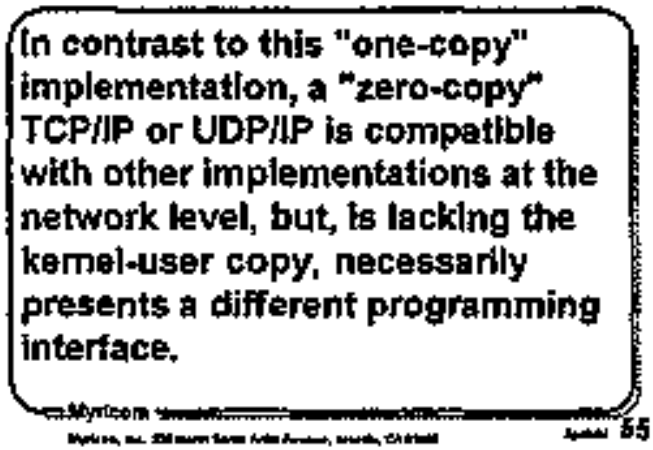

\section{Myrinet's Own}

Myricom will also provide a "feather-weight" protocol, essentially native Myrinet packets - for use between hosts on the same Myrinet network, for applications such as MPI.

\section{Expectations from SBus}

\section{We expect to be able to achiove end-to-end feather-weight transfers at about $300 \mathrm{Mb} / \mathrm{s}$ in the best-case benchmarks on these SBus systems.}

(The SBus guarantees that these figures will not be exceeded.)

\section{Zero-Copy}

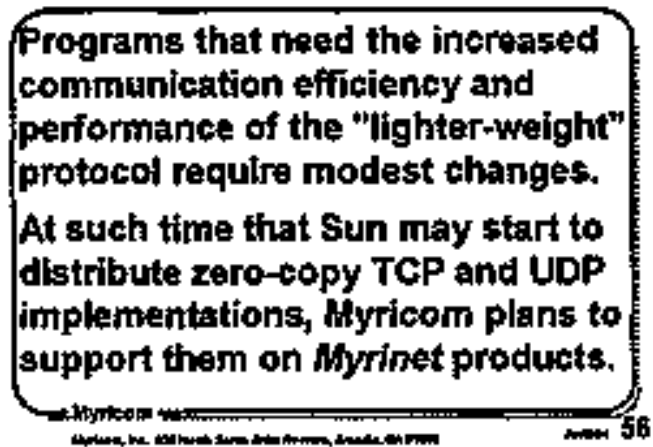

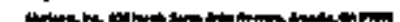
anch

\section{SBus Performance}

the performance bottleneck when using this protocol is the SBus, limiting the transfer rates between the interface's and the SPARC's memory to somewhat less than $40 \mathrm{MB} / \mathrm{s}$ (320Mb/s) on models with a 20MHz sBus, or to somewhat less than 50MB/s (400Mb/s) on models with a $25 \mathrm{MHz}$ sBus.

\section{Host Performance}

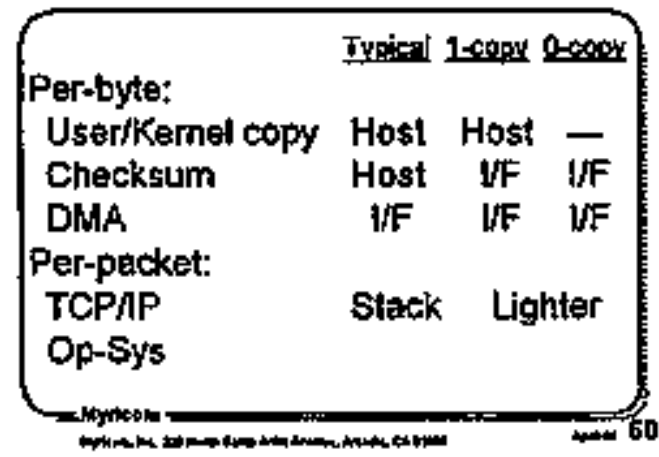



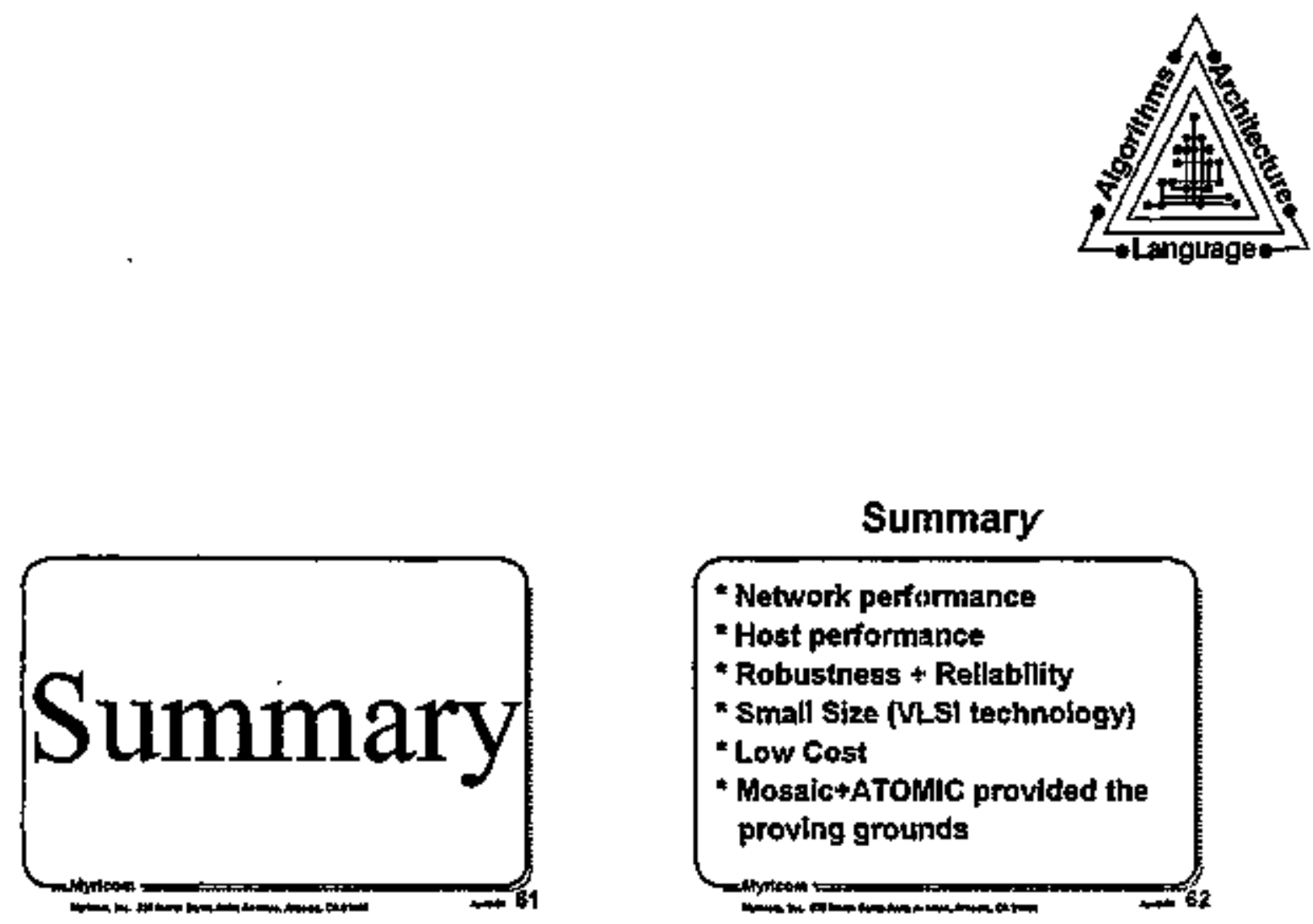

\section{Summary}

\section{- Network performance}

- Host performance

* Robustness * Rellabtlity

* Small Size (VLS1 technology)

- Low Cost

- Mosaic+ATOMIC provided the proving groumds

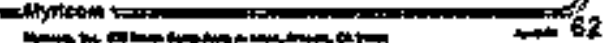

\section{Conclusion}

There will always be need for more local bandwidth than for remote. Luckily, it's more affordable. Myrinet provides low-cost Gigabit communication, intra- and inter-computer, supporting LANs, clusters, and multicomputers.
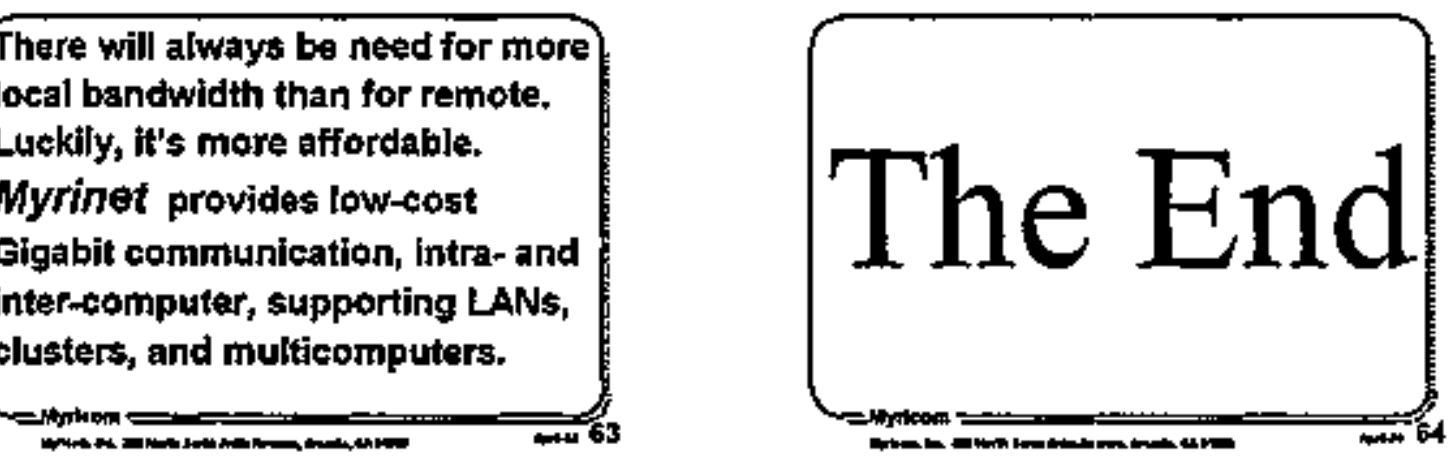


\title{
NEW FRONTIERS IN \\ WIRELESS COMMUNICATIONS
}

\author{
James Stuart, Calling Communications
}

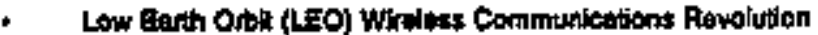

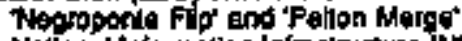

Nationtal hitamation Irírasinucture (Nal) and LEO's Role

- Wifotats setellte Servioes on tha Hortzon

- GSO Woblle and Wideband Systoms on the boizon

- LEO Communicesons Advaritoges

- LEO MSS Froquanty Adocalions (WAaC-ge)

- LEO hoblia Seidolile Serices (MSS) Cralpoodas and SyElens on Harizon

LEO wss Syanm; and Comparieone

FCC Approval Stalus of MSS LEO Syems

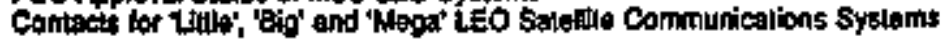

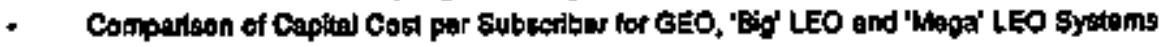

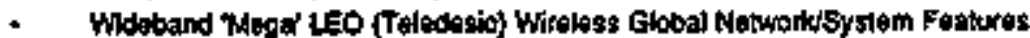

Tiglatasio Copportiton Bactoround and Slatus

Telectasic Notwowx and System Fealuies

Teledesic Space and Ground Sagment Fuatured

- Wiretass Ravolution in Now Sarvice Providert and Now Equipmend Suppilers

\section{The "Negroponte" Flip}

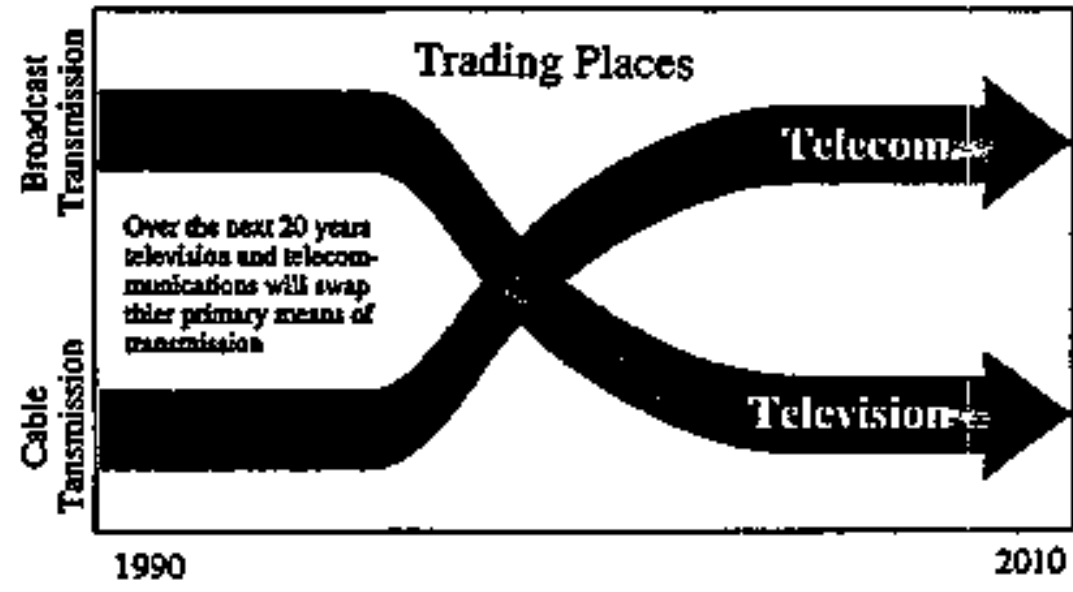




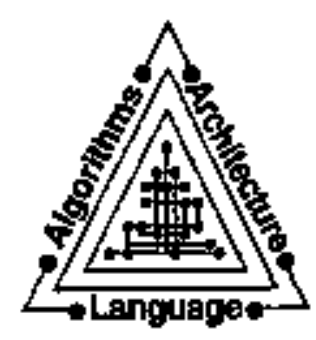

A nore Recent Vlew of the Cormunleations Áevolution

\section{The "Pelton" Merge}

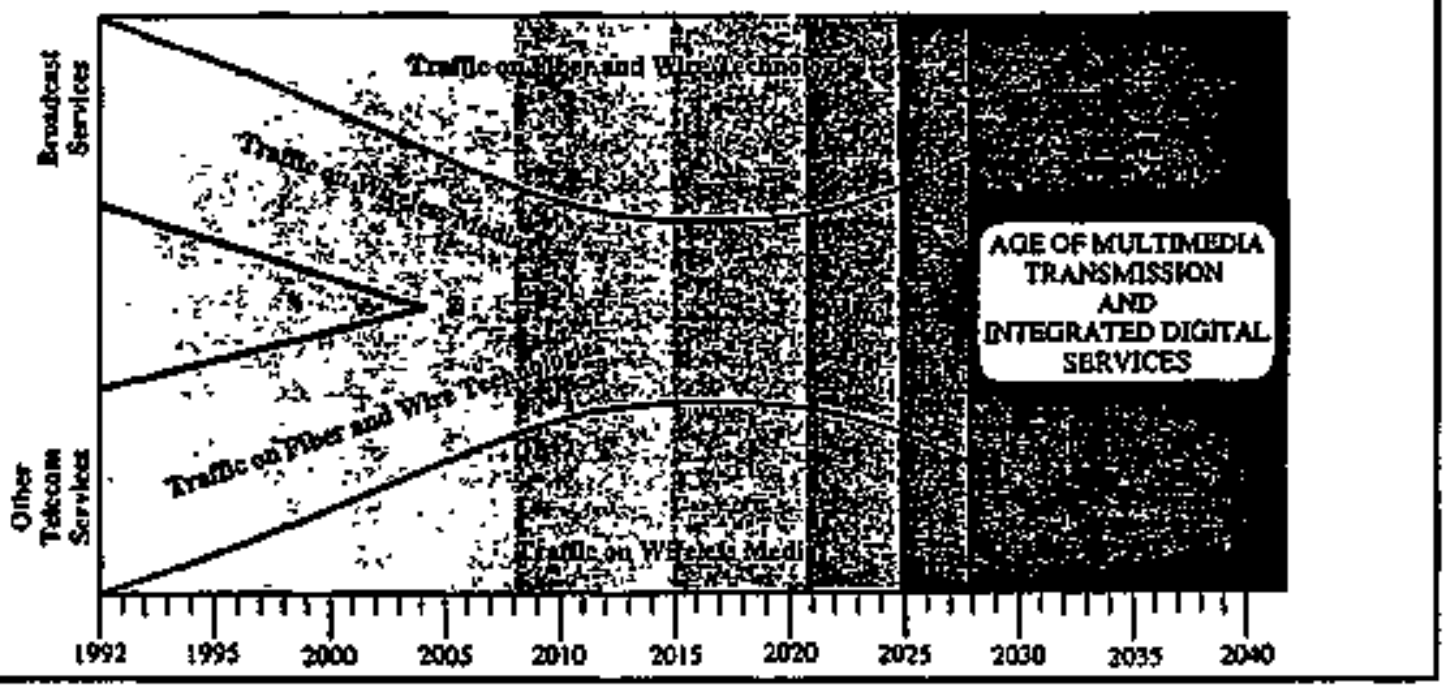

Low tarth Oroll (L9O) Wirelass Communications favelutbon

- LFO Communicetions Senves Hrid Be Avallable Giobaly and Econorically.

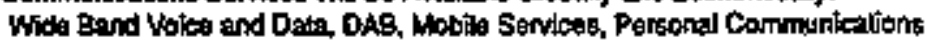

FAX, E-mall Short mostaghs. Monitoring, Aarms, Positioning. Tracking and Locallan

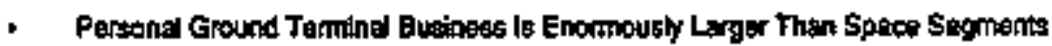

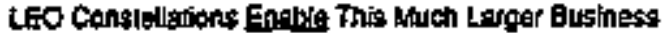

Hottesi Now Parsonal Elogtonle Products since PCo and VCR's Wil $B e:$

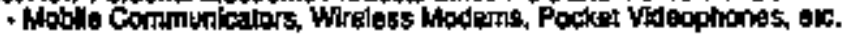

- Shih from Last 30 Years of Setolite Carmminications Evoluban:

Bjgarr. Lore Powertul, Langer Liled Setellites

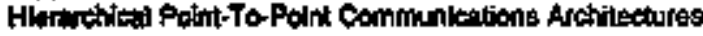

- Blogest Advaneg ho Satollte Comownicotions in 30 Yams:

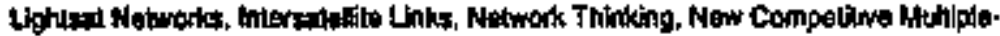

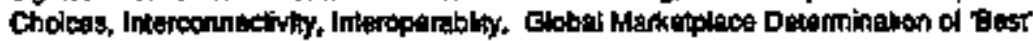

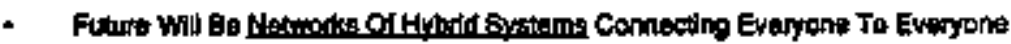

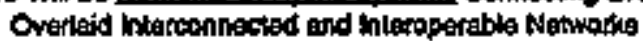

- Torrettiol Wire, Celutar, Coaxiol Cable, Fiber Oplte Colble. elc

- CSO Lage Satedites, end the New LEO, MEO and CSO Lighisds

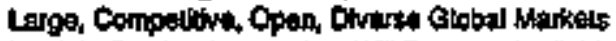

Muliele Senvica Approectes Will Become Avallable to All Custorners

Continsous Evolution of Host Hifective Set of Comrunications Natworks

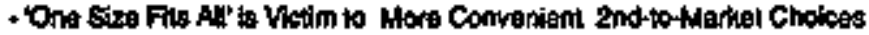

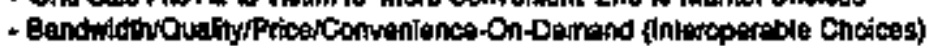




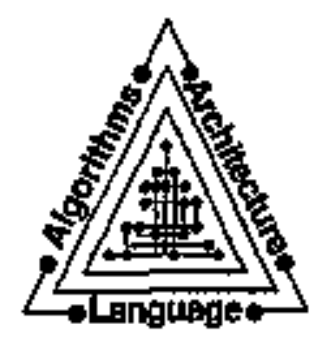

Nailonsi intotmation infresirutture (Nis)

- NII is a Vision of a Untrassily Accossible Web of Huliple inlerconnected Netwotls

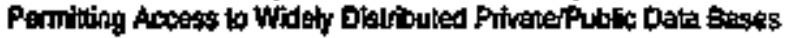

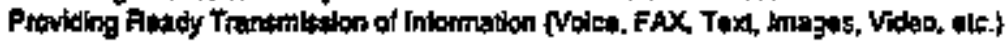

- in Any Format, To Anyope, In Any Ptace, and At Amytine

- Nit is on Erdre Nil Byotem.

- Hurnas Users \{and Developers\}

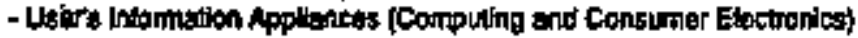

- Acossed Intomatorn, Dala Bases and Computing Resoutcest

- Nontroiks:

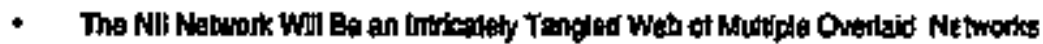

Wing and Wheless

Terrostifal and Space

Pmysterar and Vinial

Phroto, Comunated and Government

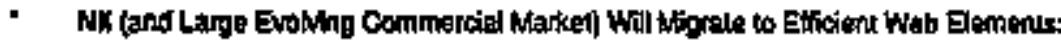

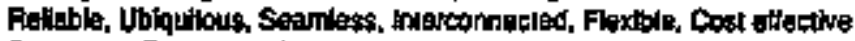

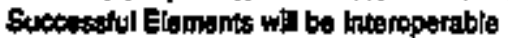

- 'Operí Imbraces with Accepred Stindarts

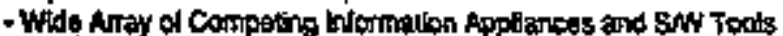

Inleroptrable and Ińlerchangatable by Desigr

Siand ard User-Friendy (Eesy) Intarleces for HWW and SAnt:

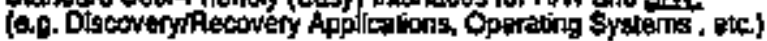

- Hery Interchangeable Comjoting Sentes Providers and Equpment Supplins

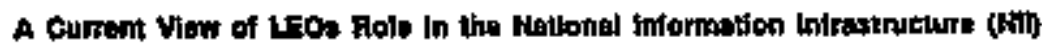

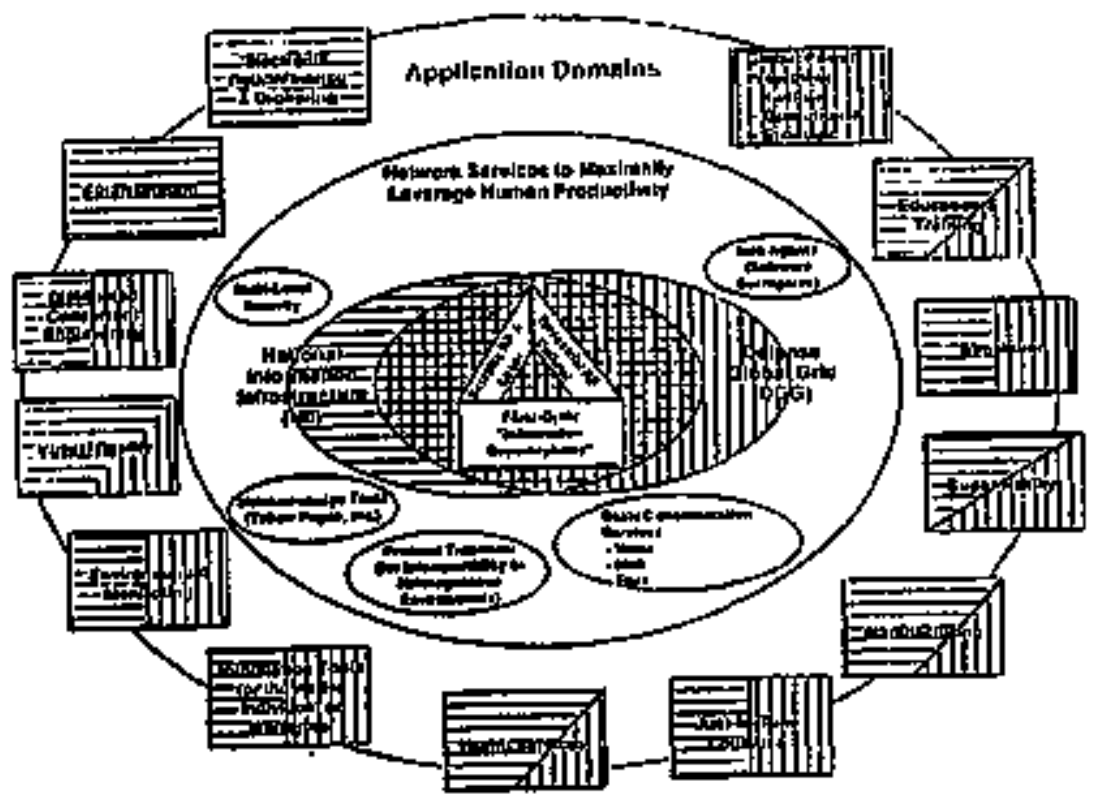




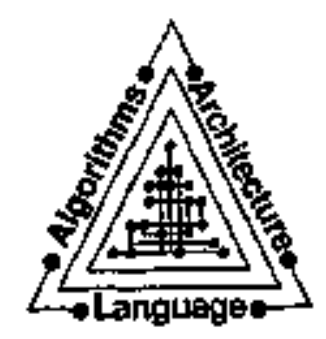

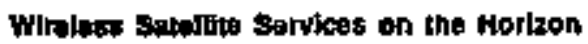

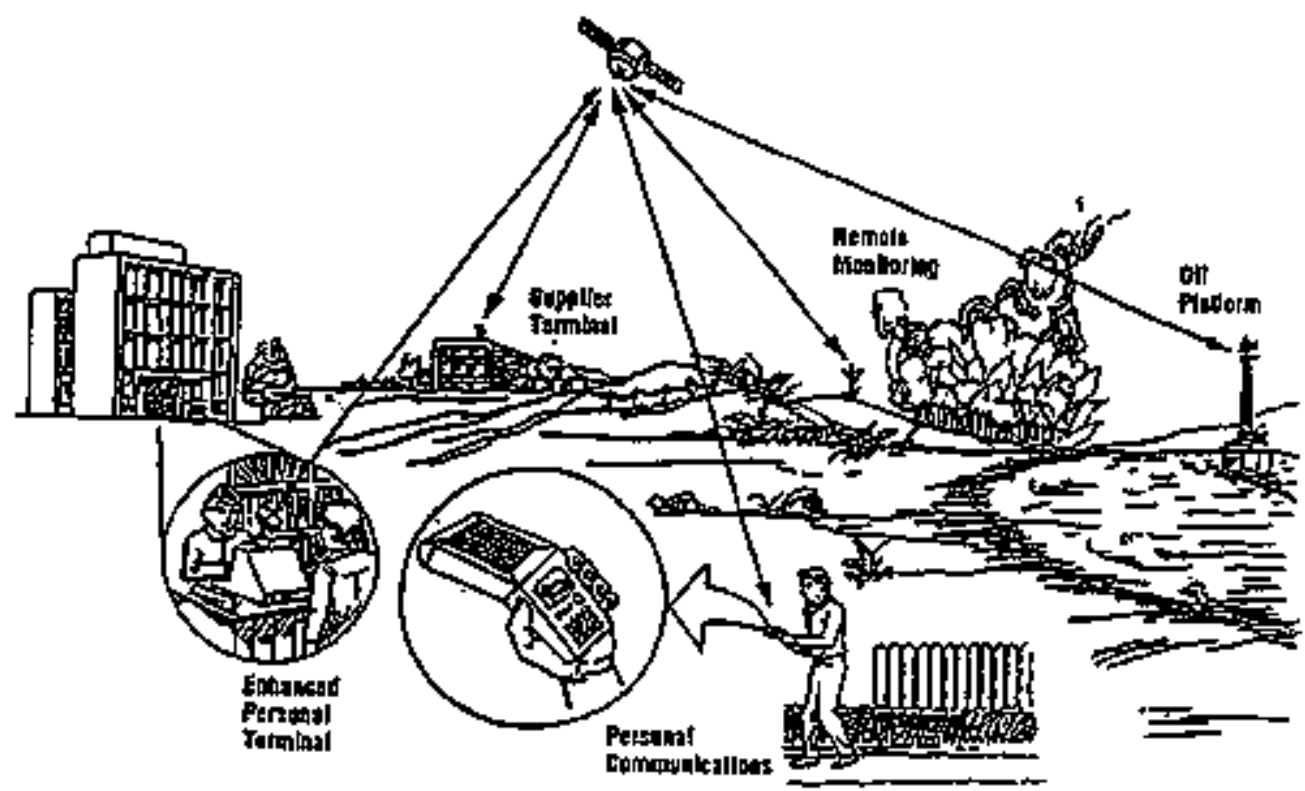

\$80 thotho and WIdeband Communlcallons Byatems on the Horlzon

- MSS ESOF Abovin 1 CHtz:

ANSC MABAT, LSA

Cod topt (Colvtar), USA

WMARSAT (Inrat:al), Europe

Mexico (Solltarldad), Mipition

Totoral (USAT), Goneda

(+Othar Wallongl and Roptonol GEOS)

- MSs 6sos a $2400 \mathrm{ct}$

ISAS (ETE-VD), Japon

Nond (Nowstah, USA

NTT (N-Stay, Jiapen

NASA AACTS, USA

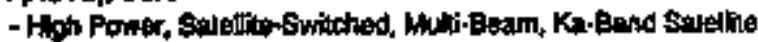

2,4 Year Lituline, in 100 W Stok.

E Ka Geand TWTA's (20 GHz, 48W) thtoun $3.3 \mathrm{~m}$ Anlenna

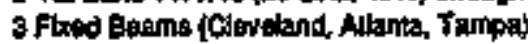

Stowrtbla Hopping Spot Beam (650 km dam. at mi ckmel)

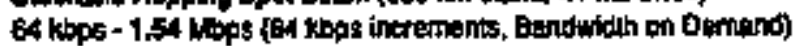

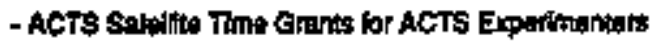

770 Experimenters to Date

10 Senice Prowders, 8 Exupmenl Providers.

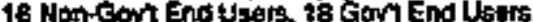

17 Untwerstiog an. Universily of Colorado al Boudder (CU)

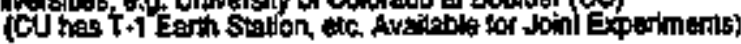

Conber (or ACTS Experimenl Mro: Tom Weyter (503) 494-8144 


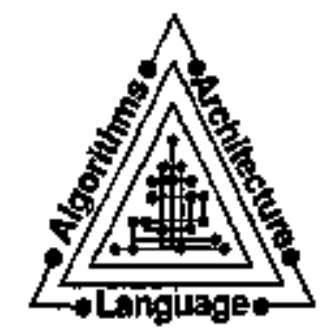

ACTS Moblia Exporiments (Extimplas)

\begin{tabular}{|c|c|c|}
\hline Exposment Tho & Pringlas monstiration & 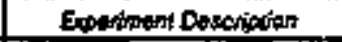 \\
\hline Ind Model & 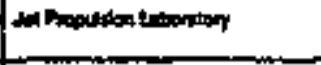 & 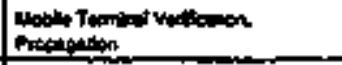 \\
\hline (1) & 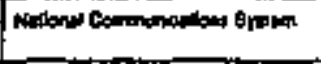 & 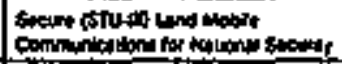 \\
\hline Cothinthon & wh. Amy & 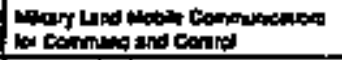 \\
\hline 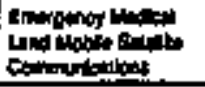 & timess. & 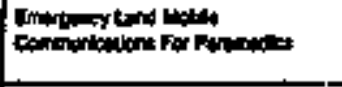 \\
\hline tritim & 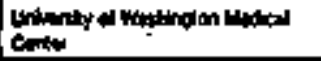 & 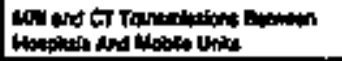 \\
\hline 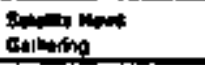 & 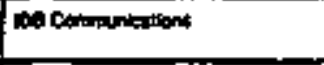 & 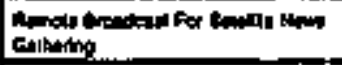 \\
\hline 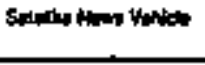 & vac & 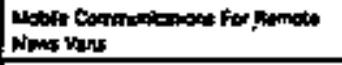 \\
\hline 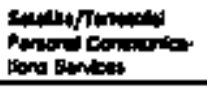 & 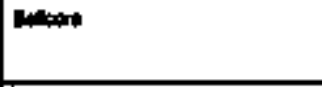 & 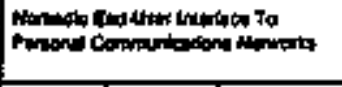 \\
\hline 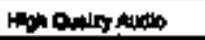 & cas ands & 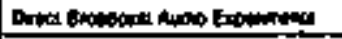 \\
\hline $\sin$ & 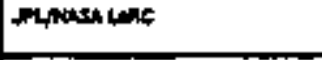 & 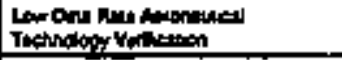 \\
\hline 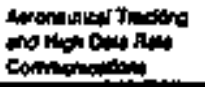 & Fophwircesins & 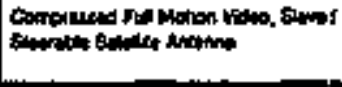 \\
\hline
\end{tabular}

Commundeations Advanteges of LEO Syetims

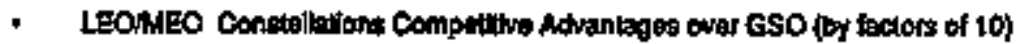

- LFO Parkrmanco Advantages

Conmunicatons Uniformithy

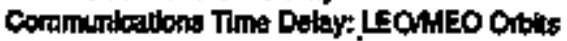

increased Lhak Hargins (to timies dowar thoin GSO)

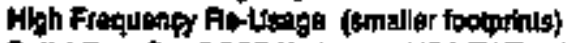

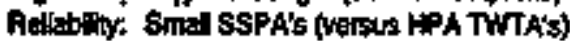

Aedundanty: On-Oth Spart Lohlints

Graceful Introduction of Naw Techndogies

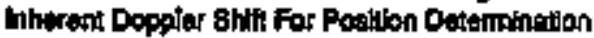

- 250 Pilco Advantages

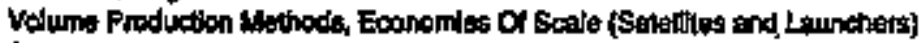

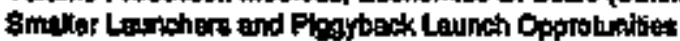

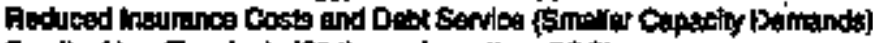

Smaliar Uas Teminals (50 times doser thar CSO)

inerementot Ixerapes in Cepasty Can Follow Actual Dersand

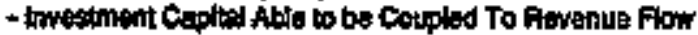

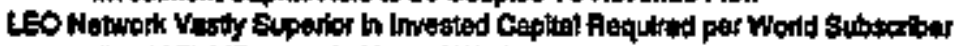

- "Lest Wa' (Perrata in Hos of World)

- Marainal Cost Oa Nent subserbers, ele.

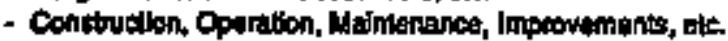




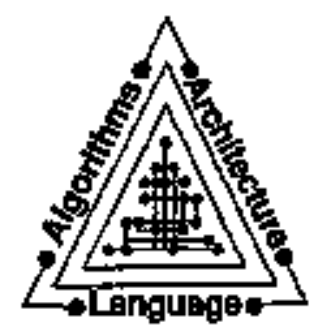

WARC-92 LEO usS FroqLendy Allooatlions.

WAf:C 82 (Torrtrolinos, Spain) Conduded on 3 Nisch 1 tige

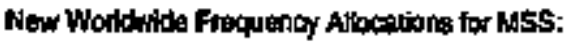

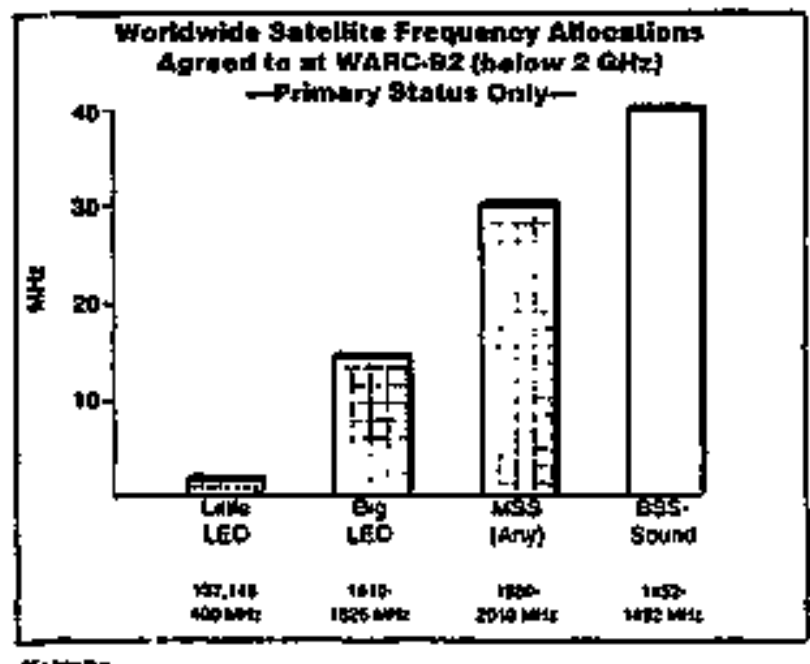

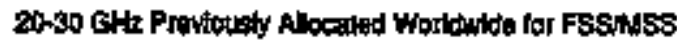

IEO Hoble satellte Serviou (MSS) Cotegorias

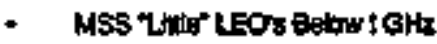

Noncontrusous Workwide Coverage,

No imerselallite Lints (yet), "Sthe-and-Foward"

Catentsy, PSTN Contectians, By toss option

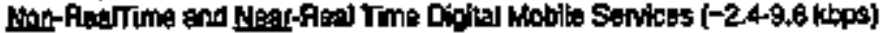

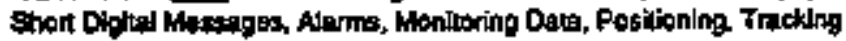

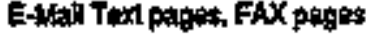

Typicel Dolvery Detay Timps

Within Footprint ( $4000 \mathrm{~km}$ Dipmeter): st0-30 minuras

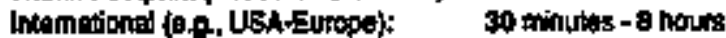

Typical subectlber costs

Tominglat $\quad 1500-\$ 100$

Date 1.06 -0.001e per byte

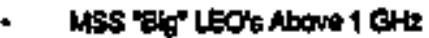

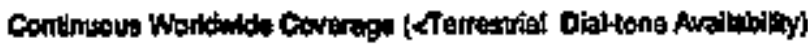

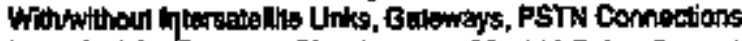

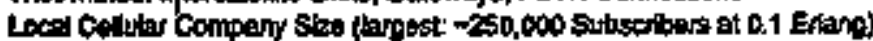

Roal Time Kotite Senveas (2 -4,8 kpps)

Diplos Voice, Natouband brie (cToll Cualty)

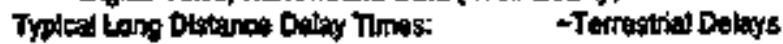

Thploal Subsaibur Costs

Torminads; $\quad \$ 1000.5500$

Dota: $\quad \$ \$ .00-50.50$ per miravle 


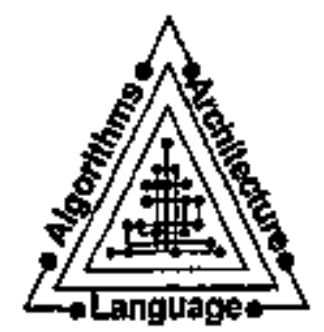

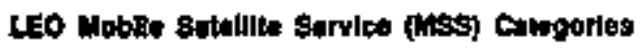

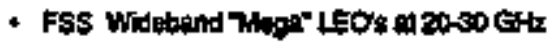

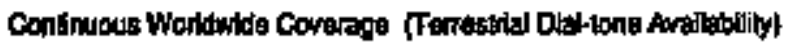

Apothe Ball Oparting Compary Size

$>20,000,000$ subsechors al 0.1 Ertang

intorealellie' in's, Ealeways, PSTN

Roal Trre Flud and Upbie Swicas (\$6 kbps-1.2 Cbps\})

Bandwitth on Deinlind

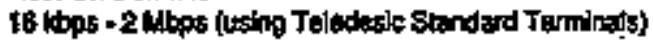

155 Htops - 12 Gsps (using Teledesic VigaLink' Teminals)

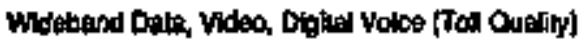

A Typleal Para Compary Servess and Faoturas

Typited Long Distance Detay Tínes: < a fiber

Typiagl Subuthor Cosis

Terminals: $\quad$-\$1,500 (and tallng sherphy whith woluma and compeition)

-57,500 for Cigalnk' Terminals (aud falind shaphy)

Data: Corparable to local PTT chappes (elew 2 per mintese)

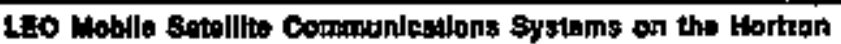

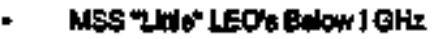

LEO CNE Panematcana (LEO ONE, Maripo

12 Sotellicas (4 inglined 1100 tem oblst)

Osc tortemm?, usA

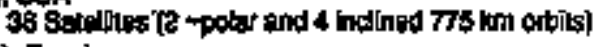

Smaksal (Conset, Rusist

35 Sateilites (6 inctind $1400 \mathrm{~km}$ othtss)

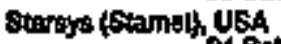

VTHA (NTA VAA

Q4 8durians (s halind 1,370 kr orbits)

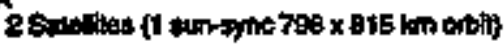

- MSSTHEOH Above 1 crz

Contstitiofitan Coinmunitations inc (Aviesh, USA

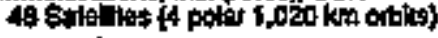

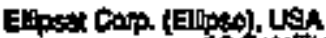

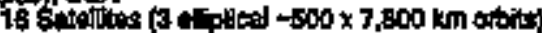

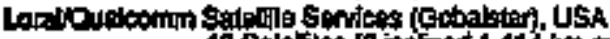

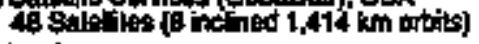

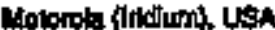

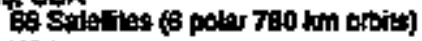

ThW (codyosoy), USA

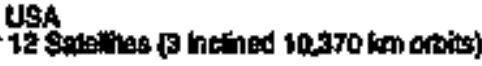

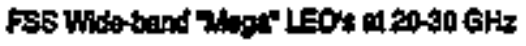

Telofoelc Corponation (Teledesich, USA

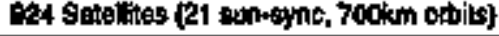




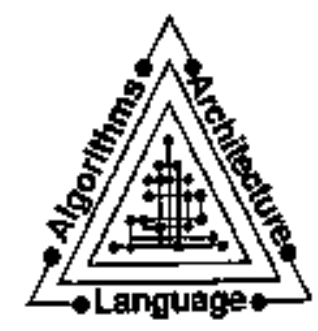

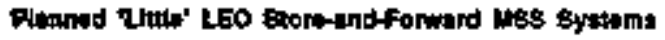

\begin{tabular}{|c|c|c|c|c|c|c|c|c|c|c|c|c|}
\hline 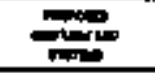 & 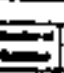 & 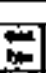 & & 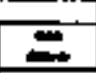 & 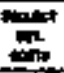 & aسm & ind & הוחו & mix & Da & $=$ & كئس \\
\hline 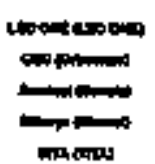 & $\begin{array}{l}\mathbf{x} \\
\mathbf{u} \\
\mathbf{v} \\
\mathbf{n} \\
\mathbf{t}\end{array}$ & $\begin{array}{l}\infty \\
\infty \\
\infty \\
\infty\end{array}$ & ש1: & 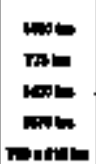 & 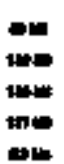 & 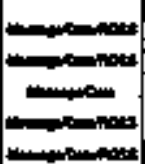 & $\mid$ & $\begin{array}{l}\omega \infty \\
\omega \\
\omega \\
4\end{array}$ & |مهمبتب & |مس & $\begin{array}{l}x=7 \\
i=1 \\
i=1\end{array}$ & im \\
\hline
\end{tabular}

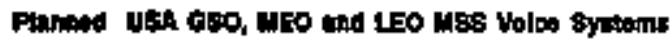

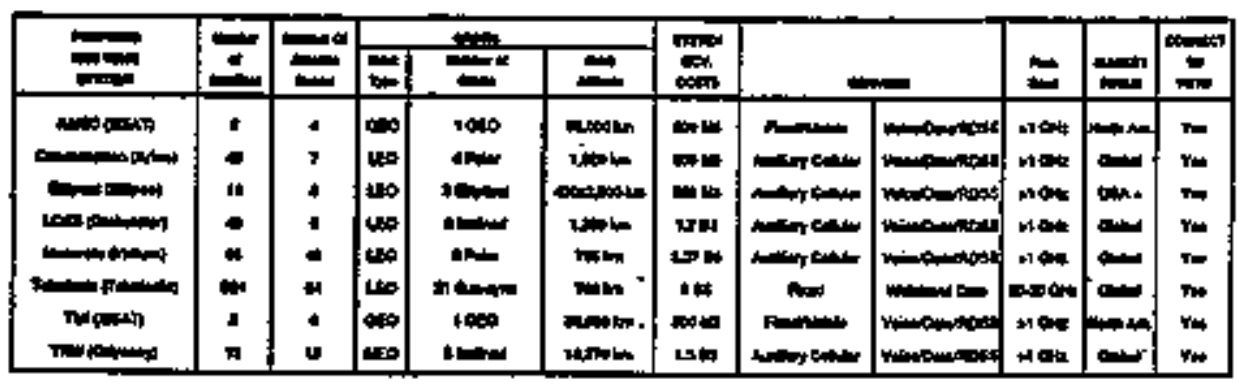

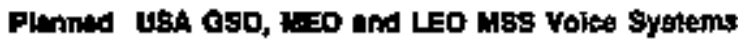

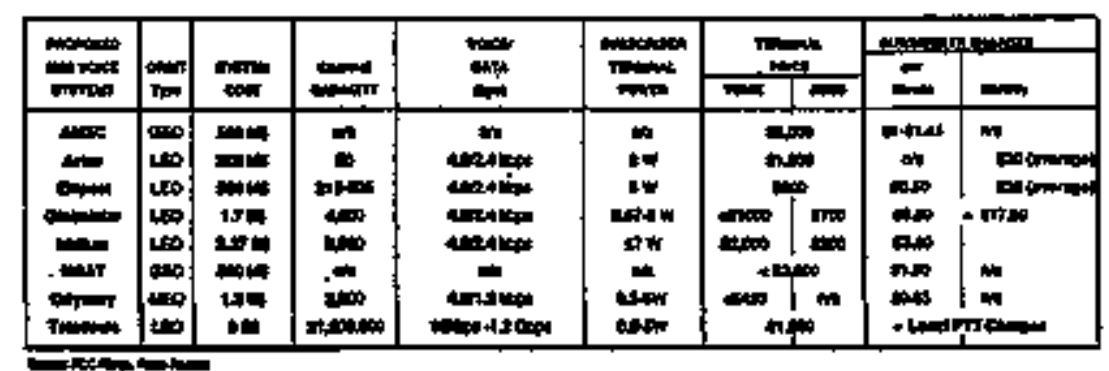

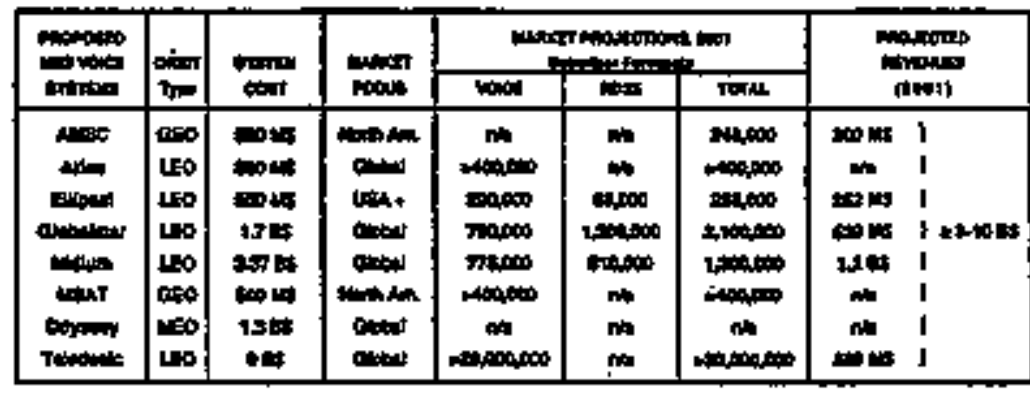

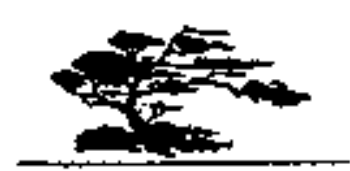




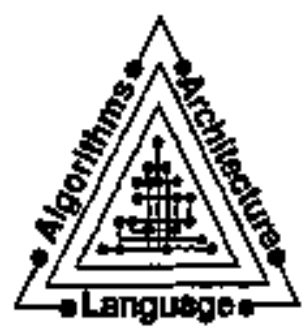

FCC Approwal siotul of MBS LEO symems

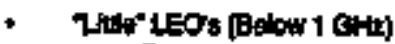

Expirdmental Leonseas cranted to 3 of the Unit 1EO/s

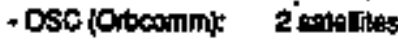

- Staroys fotameth ground lests

- VIA (VITASAT): i antiti

Pianeers Foptatanos Desigration Awarded to VTA

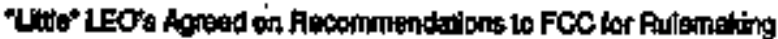

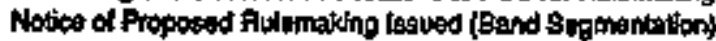

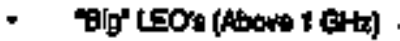

Experimental Loonses Grarled to 4 of the 5 Ein LEO's

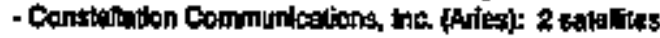

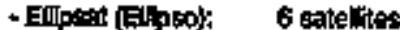

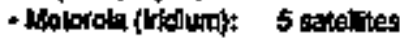

- TAH (Odjssy); ground lests

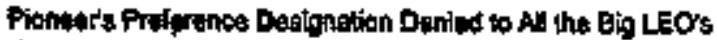

tig" LEO's unable to Agros on Reocommandatene for FCC Autemaking

Notiso of Proposed Fudemaking fssued (Bland Segmamiation)

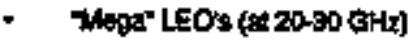

20-30 EHt Already Aliocated Wortwide for FSSnass oy ITU

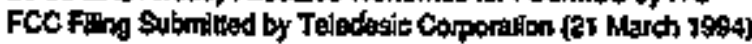

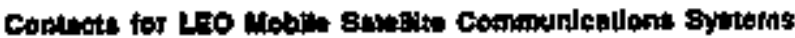

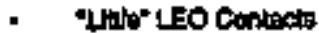

Suon F. Gomez, LEO ONE Pummintiten (LEO ONE)

(202) 429.2023, $\operatorname{tax}(20$ ) 126.6282

Alan Ferker, OSC (Otbosma)

(ro3) B18-3762, tax [70) $081-3610$

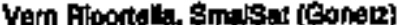

(914) $2806904, \operatorname{tax}(874)$ ses-3075

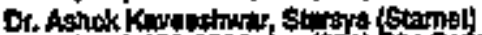

(301) 4504832, tax (301) 744-710

D. Gory Garko VTA (VITA)

(70s) 278000, tox $(70) 2434685$

- HoLEOCOnto

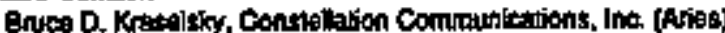

(703) $733-2879, \mathrm{f} \times(703) 793-2027$

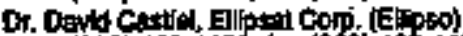

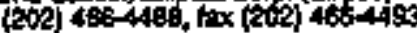

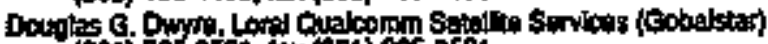

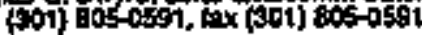

Ficbort W. Mar's, Molorala (Indym)

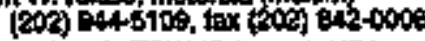

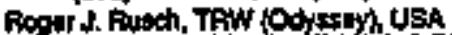

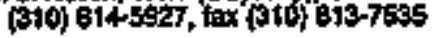

- Tena- IEOContar

Merk Lamence, Thladalo Corporadion [Tolodesict

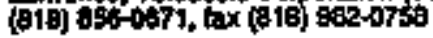




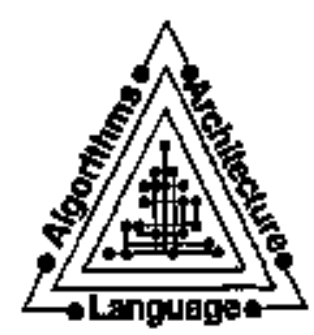

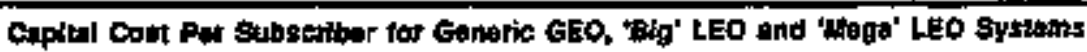

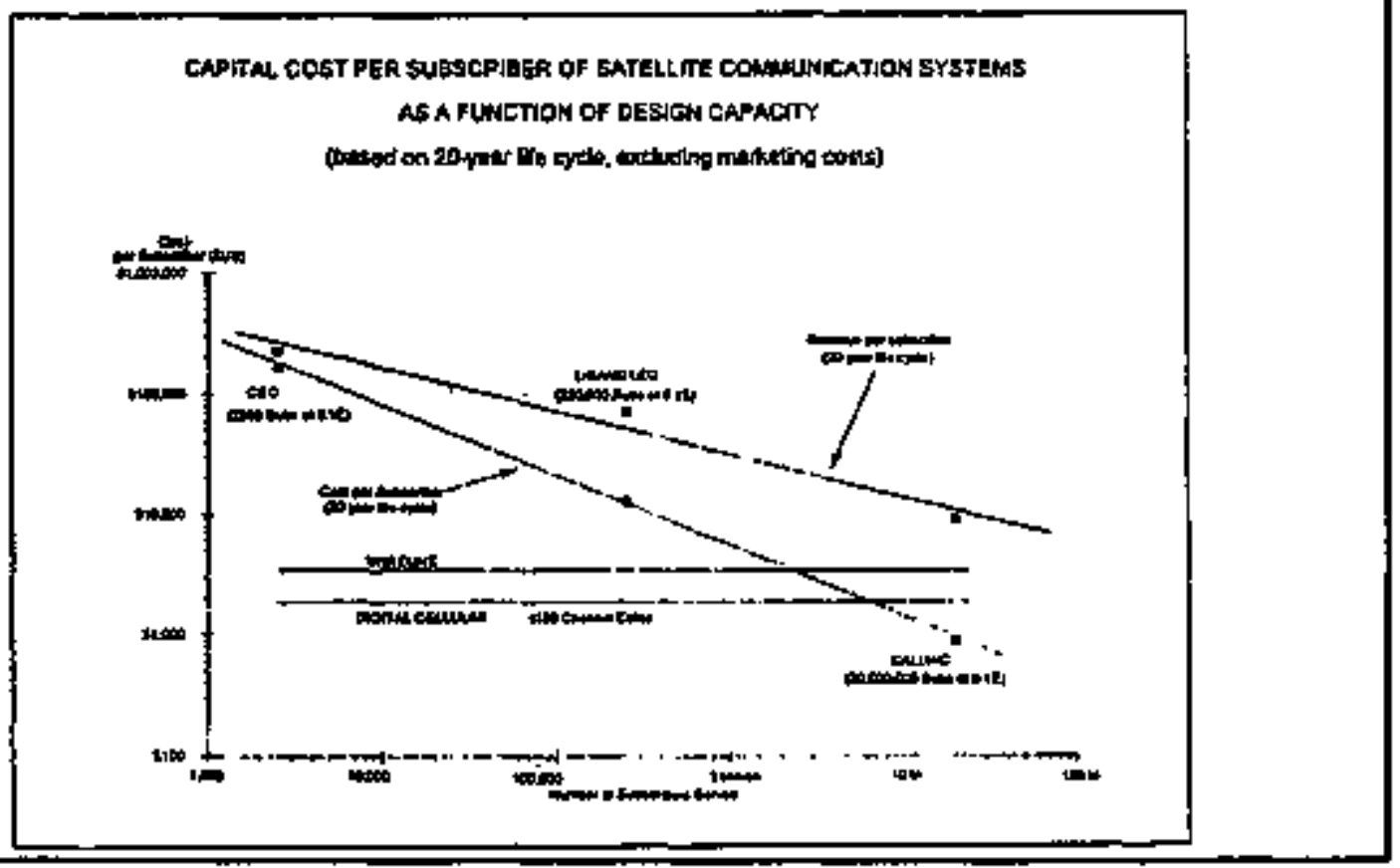

Tolodock Corporalon enokground and status

- Tolodesic Backoround

Founded in July, 1090 (as Calling Communications Cotp.)

Concept Oiginally Devaloped (redsced to wfting) in toes

Cument (end Oxis inel) Coporals Mlsstion Stalement:

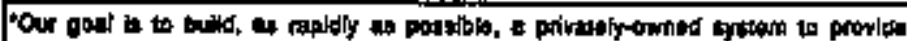

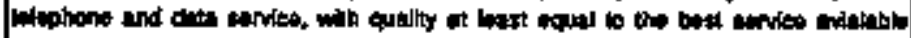

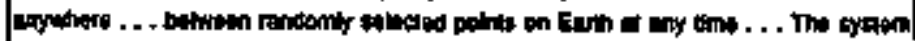

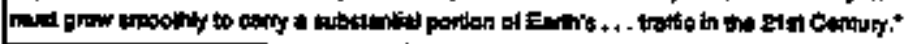

- Telodosia Sianus

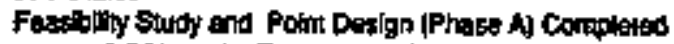

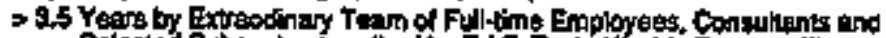
Belected Stbeontractors (Led by Ed F. Tuck, Knstip Partinats ill)

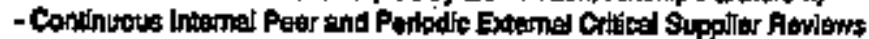

- Extanal Toledasic-Contracted Tedinleal Amiews Desion Aucits

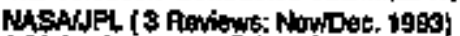

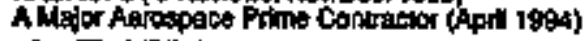

FCC Applinetion Find (3/94)

Primay Shariaholdts:

- Hr. Coigo. Necom

- Mr. Witim H. chates

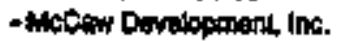

- Kintep Patrers-ll

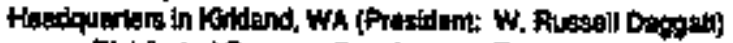

- Distrlatiod Program Dowolopotrend Tean 


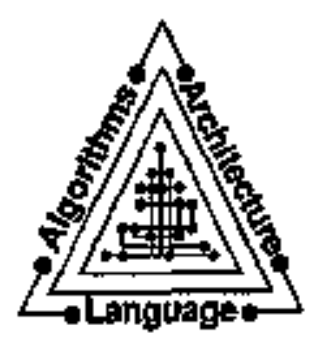

Telodesic tarvicens and Applicationg

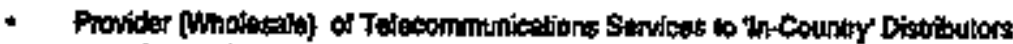

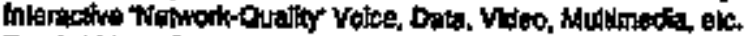

Bendwitth-ton Oomand lo Waten Usir's Applipations

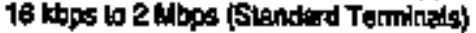

155 Whos to 1.2 Chps (Cobalnk Torminats)

- Swished and Potit-to-folnt Connesilons

Directy Bothwesn Taledasia Notwonk Torminals

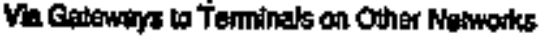

- Teledesle Brrice Ouality

Comparabta to Medem Utam Nobmenk

'Flber-Like' Dolays

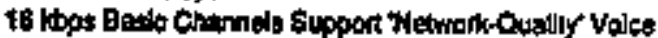

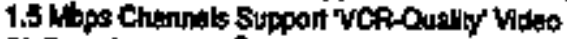

Et Eror Alates $10^{\circ}$

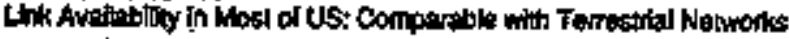

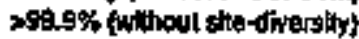

s.99.89\% (wh the-diversiby)

Toladoso capathy and Coverag:

- Toipdeste fionork Caparth

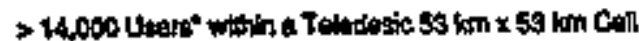

> abo00,000 Usorst Clobely

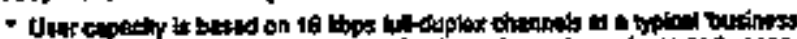

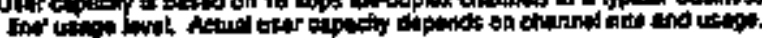

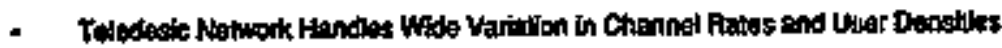

- Telodastc Conliwour Coverage Zone

- Hox of Earth buntion

$>$ Sagx of Poptation

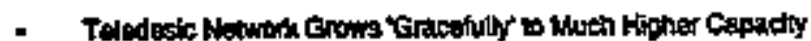




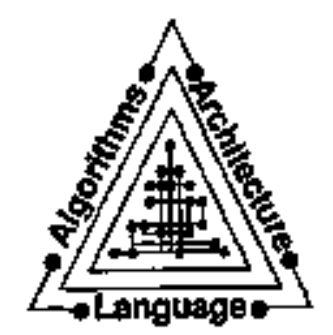

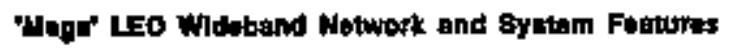
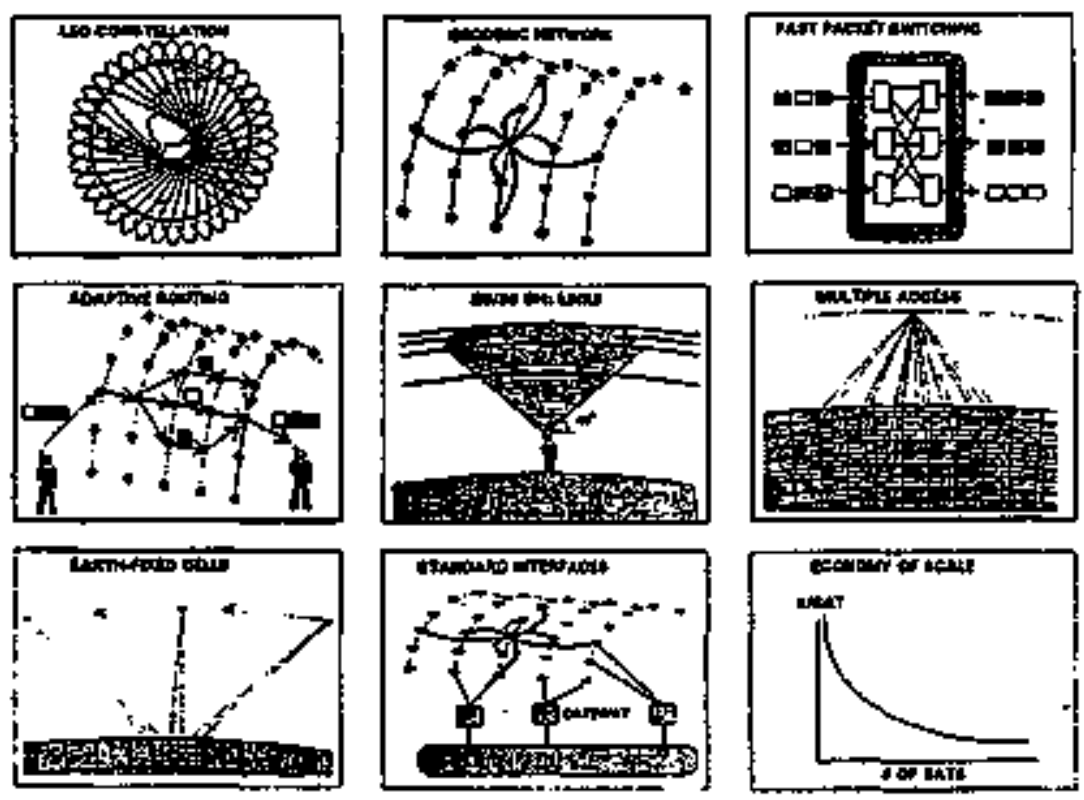

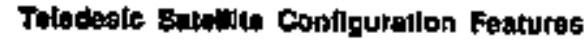
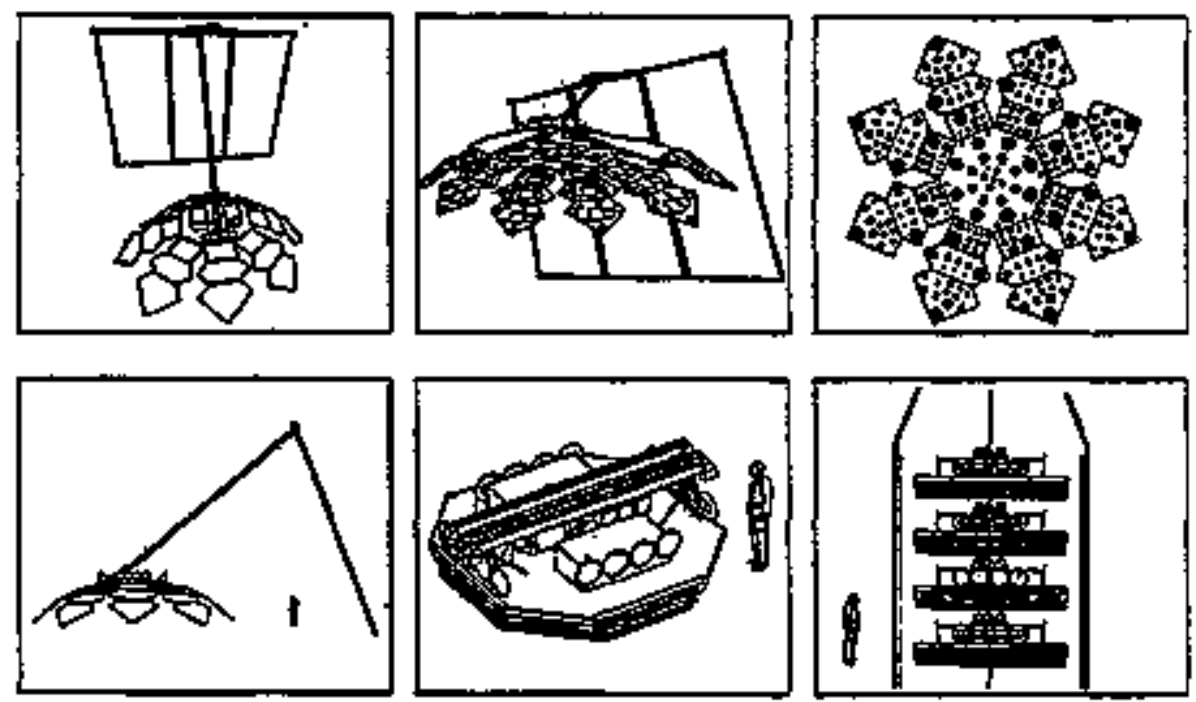


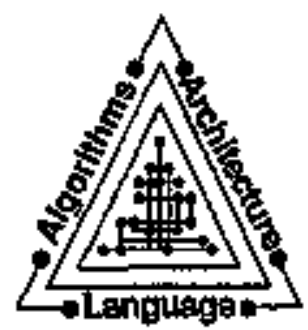

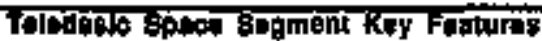

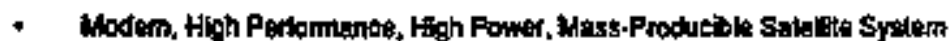

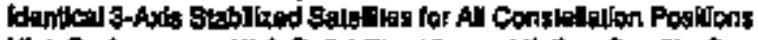

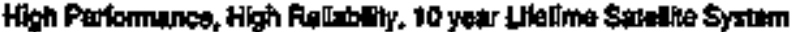

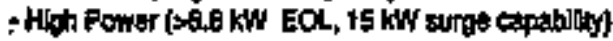

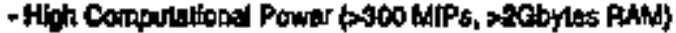

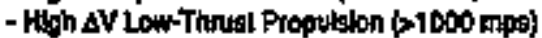

- Lohireigha (7so kg)

Actus Phase A Polnt Ousign with Lene Design Hayghts

- 20\% un Woss Volumo

$>40 x \mathrm{~h}$ Power

$>65 \%$ in Proputitiva $\Delta V$

$>300 \%$ in NlFS and 200\% in Ray

$>$ ox in Fitlobility

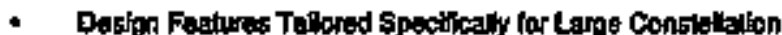

High Voums Prodiution ol Componen's (Large Economis of Scala)

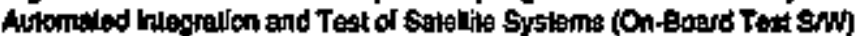

Self-Stadked, Sein-Doployed Group Launch by Vatoly of Launchers

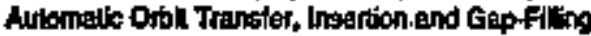

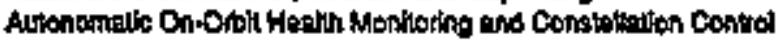

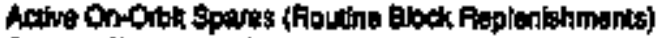

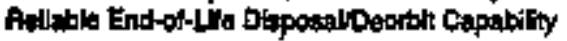

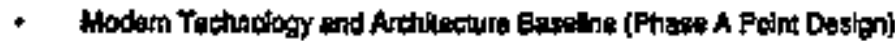

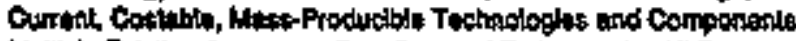

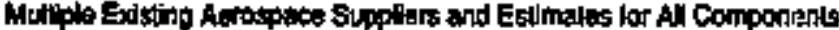

Eximing USA and miematonal Lanchers lor Pedomancercost Estimates

Toindosis Ground Sapment Key Elamapis

Terminats

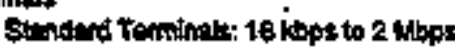

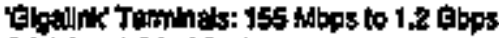

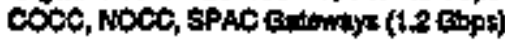

Newwork Operalians and Cordrot Canlers (NOCC)

Fedundant Fadilias, providing o.

Eltosertbar and Netwoik Dalaboses

Feathre Processors

Llawok Nanagemem

Clobal Admistution and Biling Systems

Onnod and Opinoted by Toledesto

Servoe Prowder Adminkowdian Cenlars KSPAC)

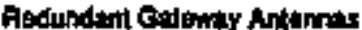

Aeglonal Adrainistrewen and Baling Syskems

Omsed and Oparaled by sentce Prowider

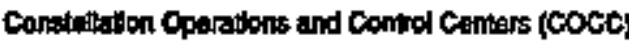

Rodundenl Factios for 4 Taens

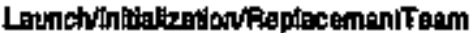

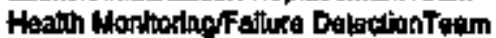

Dtepnoalc Tean

Disposald Deorbi" Team

Owned and Optrited to Tolpolosio 

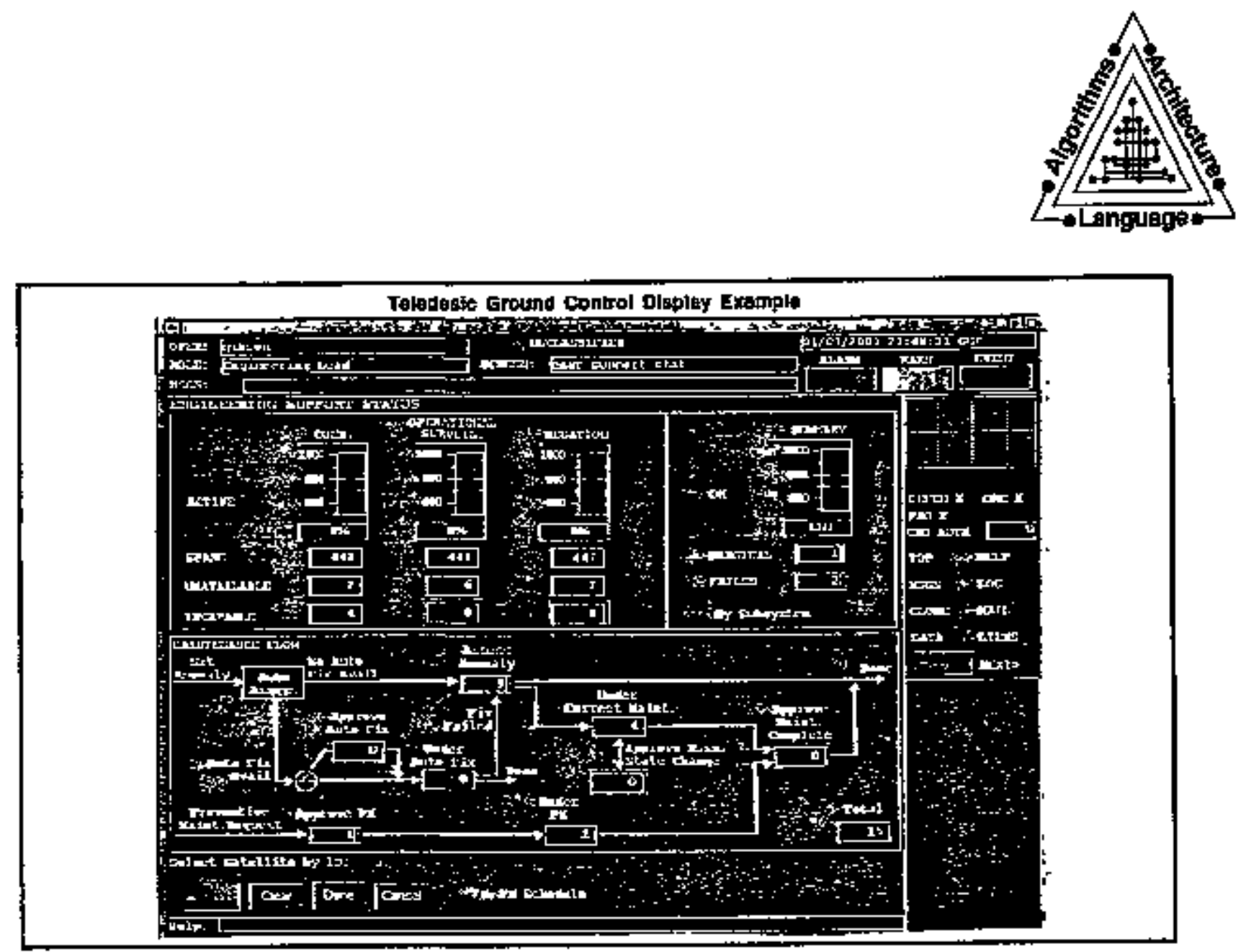

THE THLFOESW BPACE SEGUENT KEY TECHMOLOG1ES

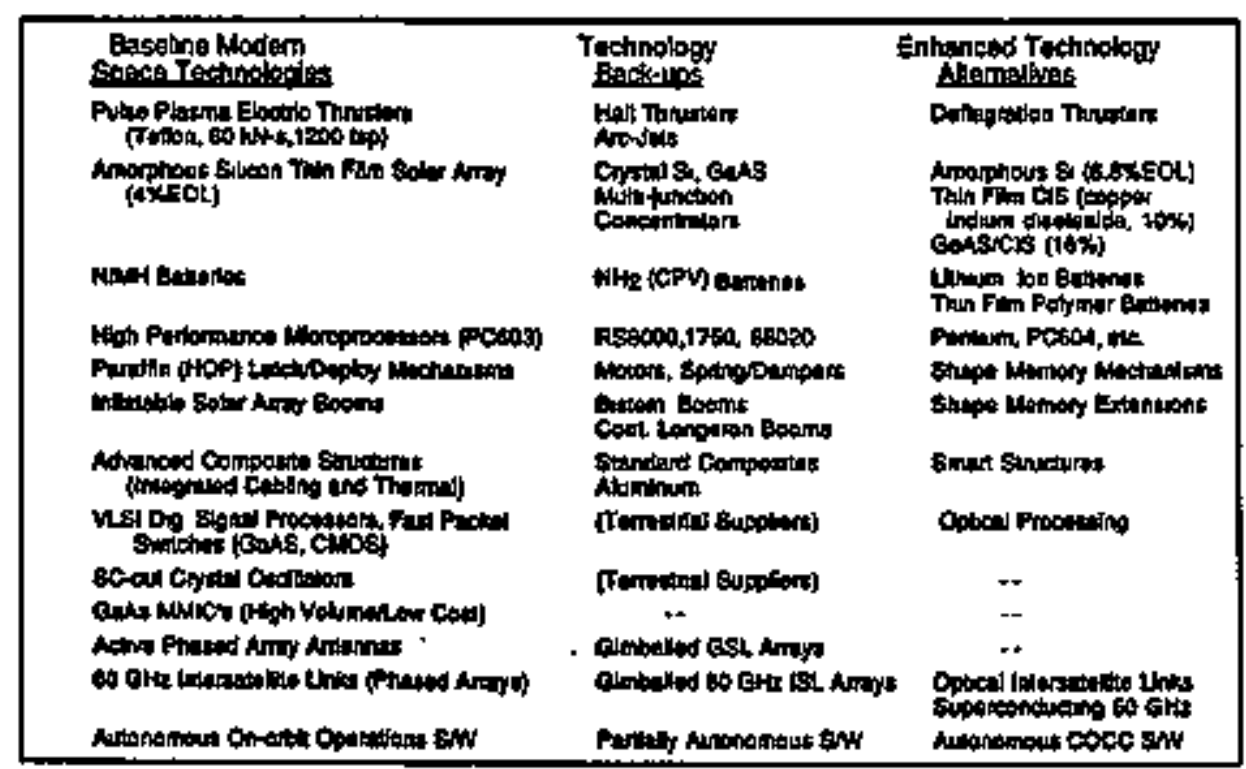




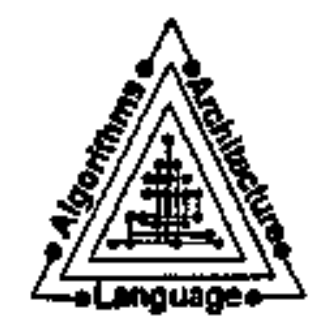

Wrakess fevolukion in Mow Service Provlders and Now Exufpment Suppliars

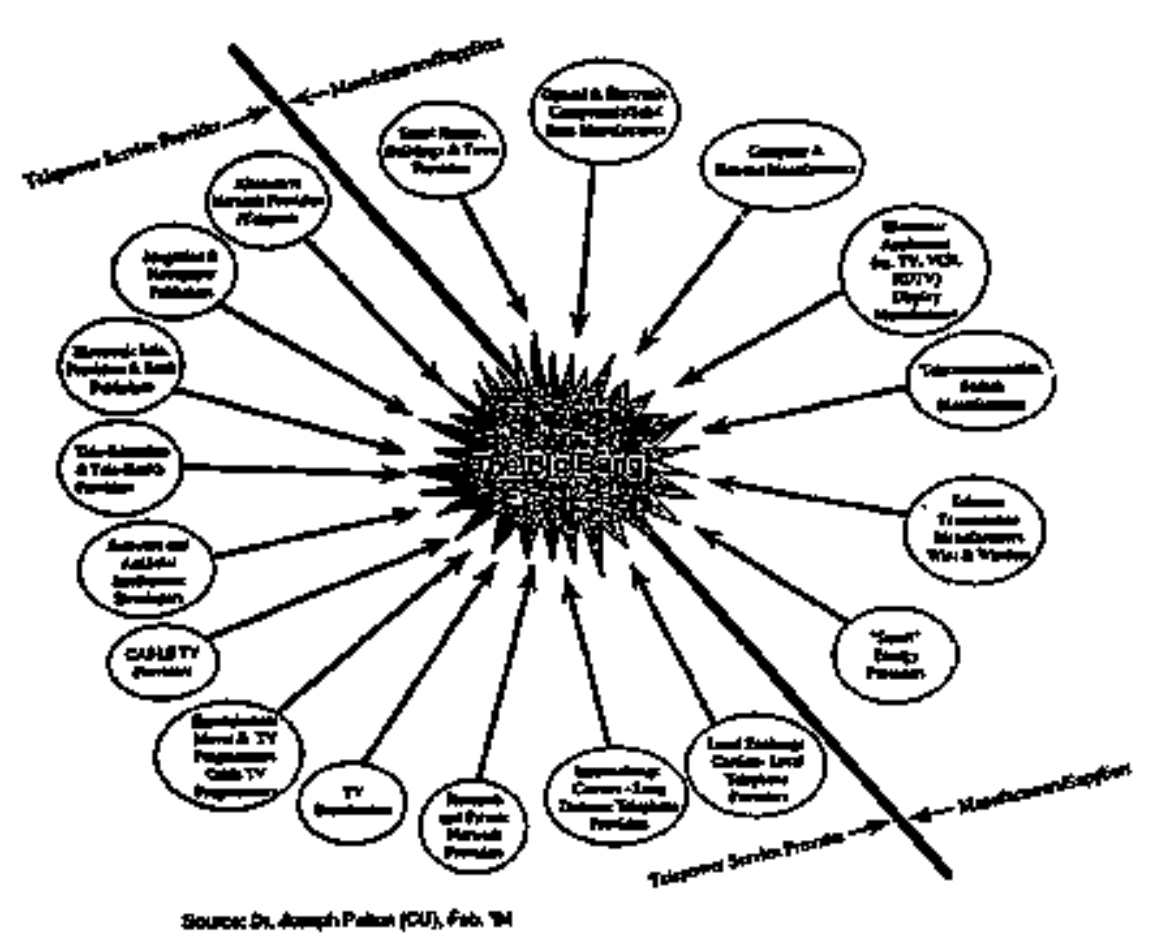

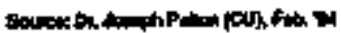




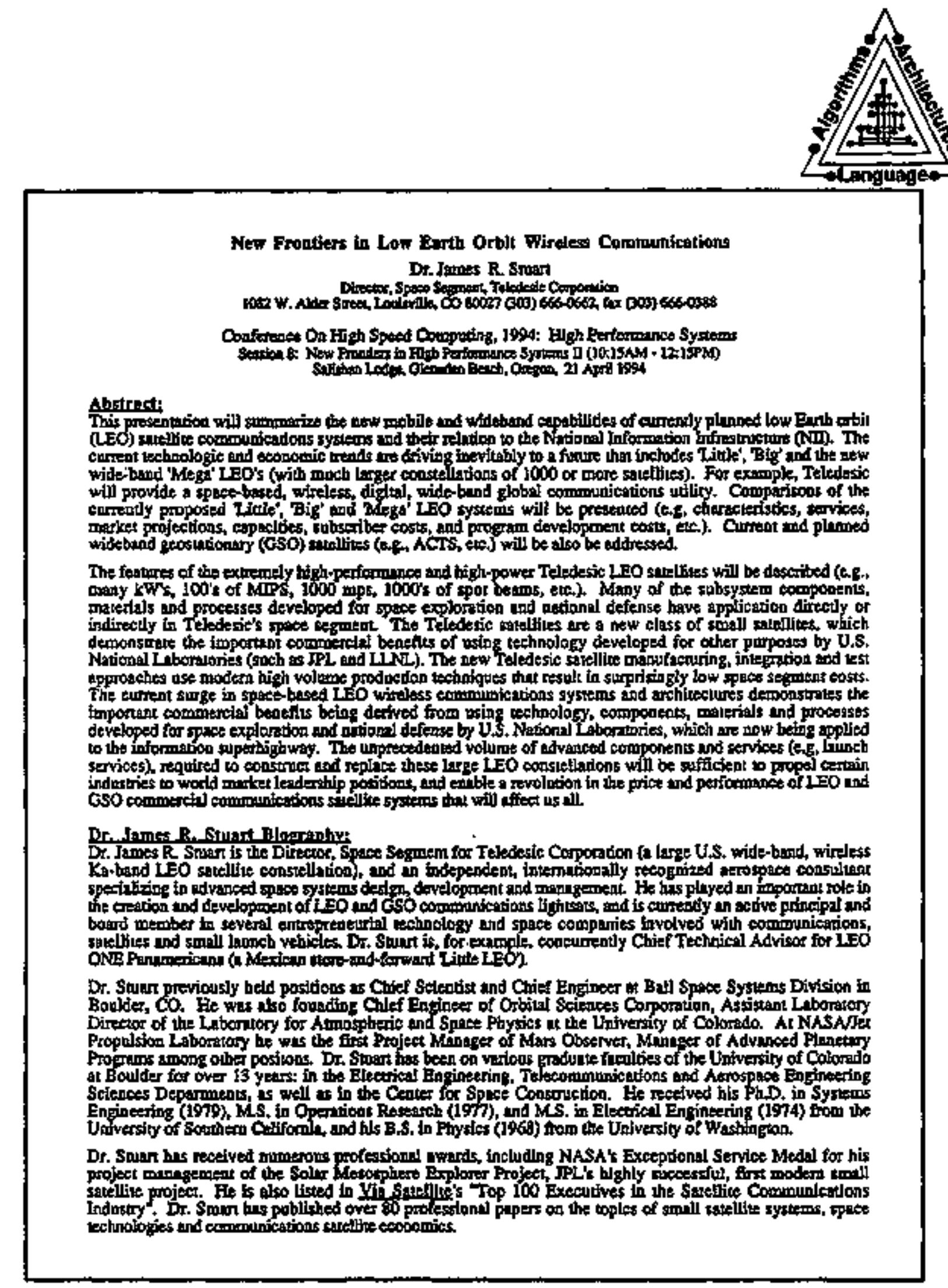

Abstreat:

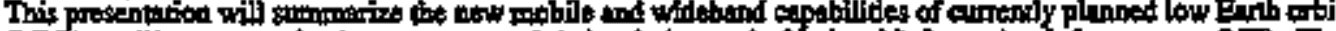
E

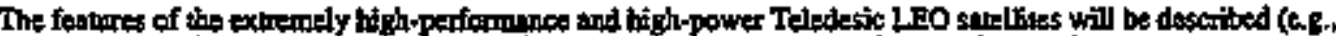

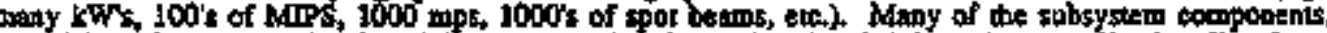

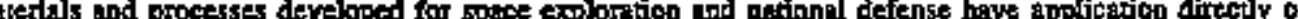

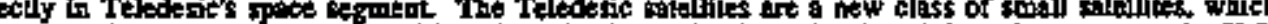

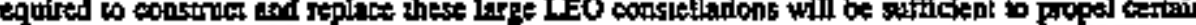

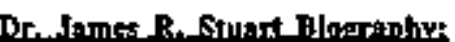

Dr. James R. Sman is the Director, Spates Segmem for Teledesic Corpordion (a large U.S. wide-bord, wirdess

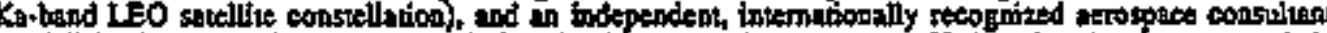

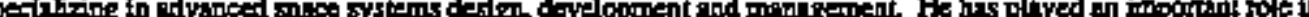

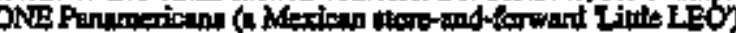

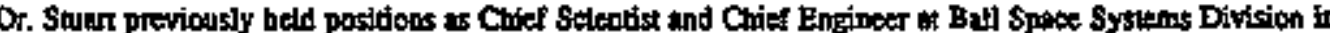

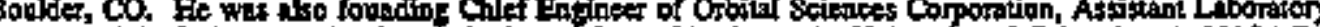

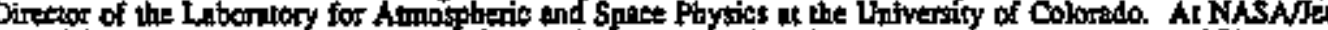

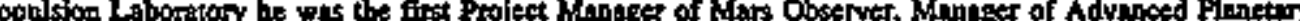

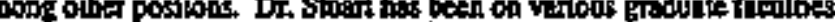

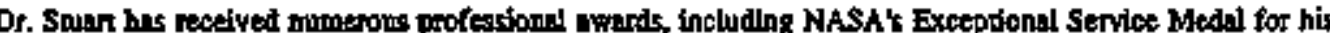

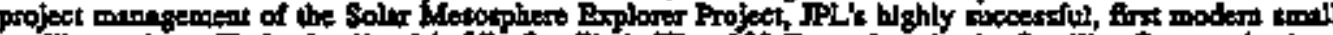

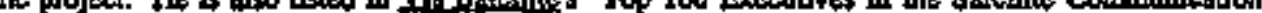

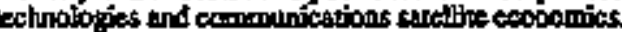




\section{SPECULATIONS ON THE STRUCTURE OF SOFTWARE IN THE 21ST CENTURY \\ Michael Gorlick, Aerospace Corp.}

Agenda

- The Sotware Concens of The Aerospeace Corporalion

- The Iniomation Economy

- Hinis of the Sothware Structures of the Future

- Testing the Software Sinuclures of the Future

- Predictions

\section{Just Who is The Aerospact Corporatlon?}

- FFROC consiluled as a pryate non-proll corponalion

- siglas arganizalions inchuts AAND, Mitre, and JPL

- Cenerdil systems enginesing and integralion for milhary space byslenss

- Primary cuslamer ls Air Force Space and Massijle Syelemo

- responstble lor everything ine militery blts into space commurtitefions, rectoninaissence, newigation, weather

- we see space sysiens trom fust to dual

enticslate requirements

wite specillealions

monlor design and fabricalon

Iradeofís

probtem resolulion

crists management

investigation and research

- Why do we cere about sotware?

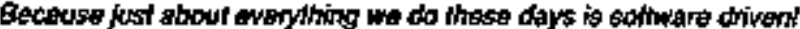

- simulal on \& modeling

- saled live leflemely processing

- netwatking

- huritaricompuler isleraction

- sothware woik emironmognis.

- arge-scalo soltware enginesering 


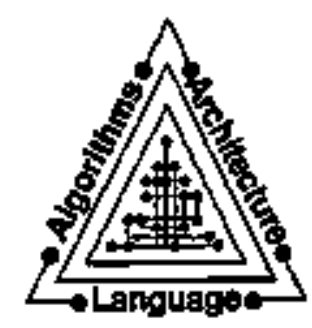

- Why do we care?

\section{The Ascendency of Informetion}

- Aerospace is one of the puregl examples of an iniomation conpany

- Aerospace hes an 16ath century infiomakion archilecture

- The survival ol Acrospece depends upon ready access lo infomition

- Jugl abouk avaryona is in the information business whether thry reglize th os not

The ascentancy of information products over phystical products

- jue infomirikn products

stock markei analyses

technied reports

data base and indiaxing sorvices (Lexus, Nexus, WAtS)

moderaked news digests (Nodnews Pusks)

- robolk manulachuing

NoxT Futroglion facility

- programinablo assembly lines

oulomolve

Hosis

- purchasing

FAST

- dasstąal manulacturing

lactory condrol

manket anabrsks, planning. sales

degign, simulailon

What are the Furdatrenlal Underplnnings of the Mformation Economy?

- Peason by analogy with the industrtal rewohtion

- eneryy

sloarn a powerful, choep Cous

- Iransportzation

roads, raihways $\Leftrightarrow$ high bandwedih nehworks

- raw materials

luthber, melels, wod = intomation \$ soltware

- socialal s legal framowork

economic, lepal, intellectual property a copynight, safware patonts

- Where will intormalion gend sothware come from?

- no shortage al sources of inlatimation

nowswires

enterpitse InIomation

MASA Eath Observing System

Intemel tratitic analysis

MAONE

- who will wite all the solhware Ihal we neadt?

Answer, Everyone will be wriling soltwers whether they realize il or not.

Wmy? Look to the earby history of the lalephone network prior to the introduction of automaled swithes (< 1920) 

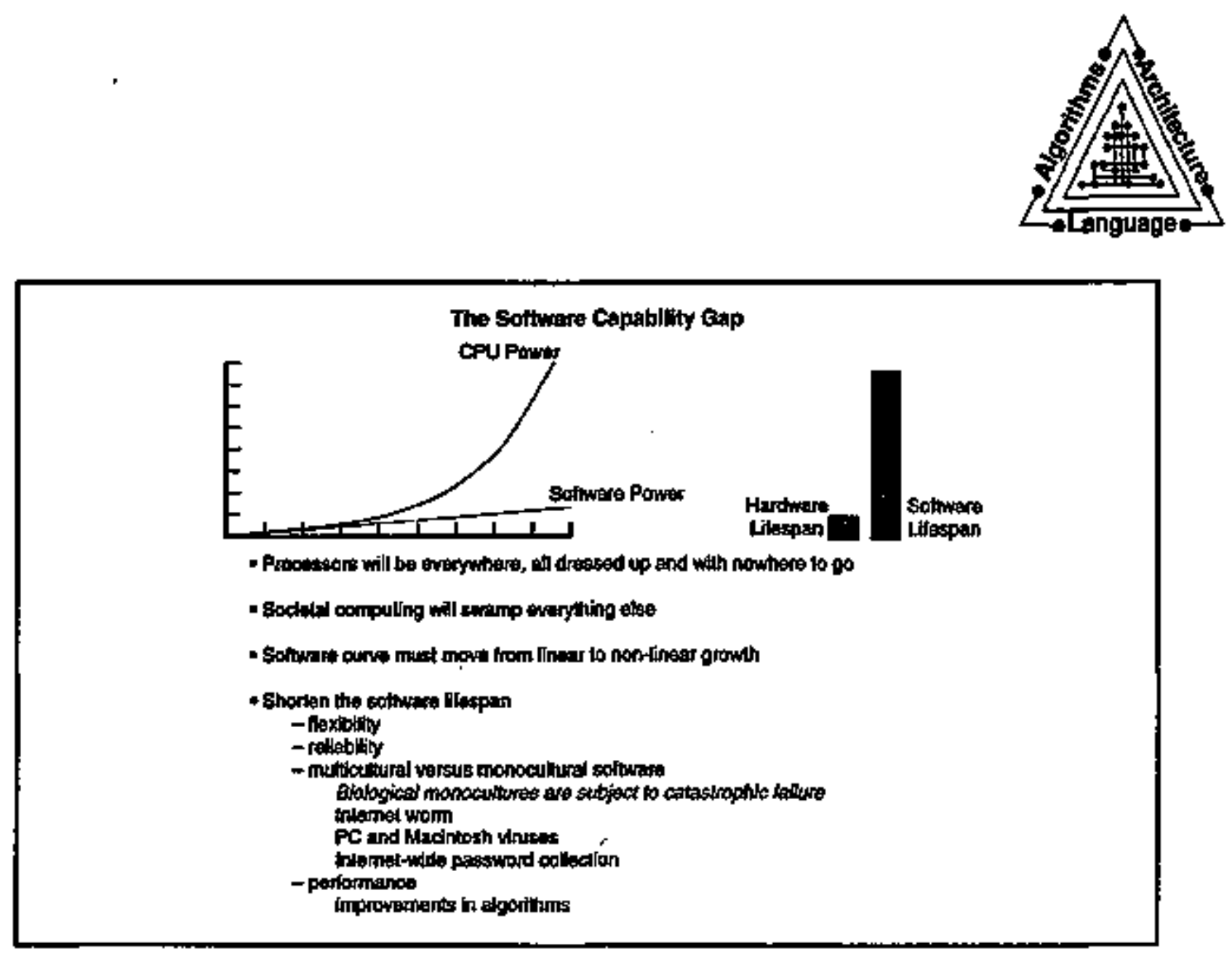

Floxlble Sotware is the Hohy Gret of the 21su Century

- Drivers for change

- etrolution in cumpuling handware every 2 yers

- the Information economy is ingatieble

- growth in miemet trafíc

- Mosaic, Copher, WAIS

- Inlerpedia

- MOONE

- infomitation spece will be highty chactic and easily disropled

- hardware feilures

- service tatures

- errors

- dellberade sabotage

- We don'l know whal we wanl umil we've bulk it

- spiral model ol software dewelopment

- rapid protohyong

Everyoting is a protalype

- Eystams so complex that no one Is smarl enough to get thern righ the first time

- Resitience in eventhing

- PTCP dichm

Accepl anything from anyone and sohere striethy to the prolosol 


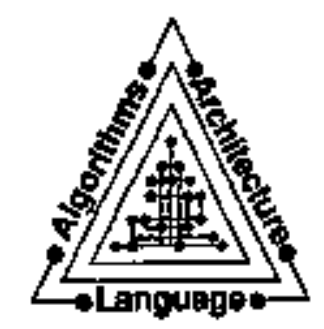

\section{Compostional and Integration Servlces as Leveragg}

- The andytical maxim ol computer sclence is divide and conquer

- 1ho synthetic maxim wil be compose and unite

- The ababration of archilectured structures is the search for composilionel operalais

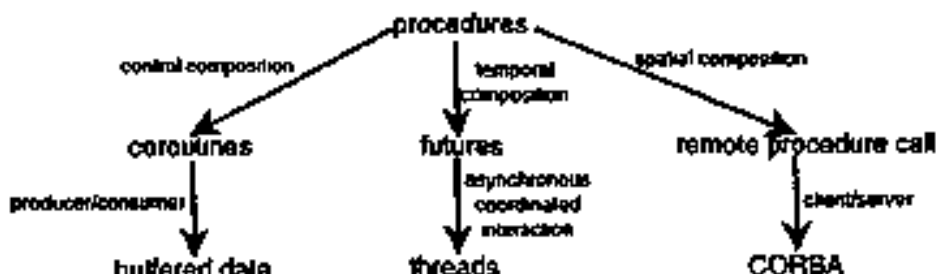

bubered dala

vileraction

- The secred is in tha glue

- Uinir pipes and tulers

- inilernels of Unbx utrites

in's ad smohe and mingots

- kitemel

If [otate composulon]

tinal (controd composiinon)

- Mosaic

threads

CORBA

a N or

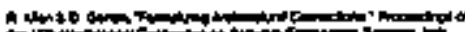
Cing

40

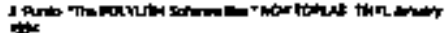
tor

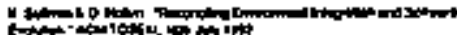

- Compositionel services are the large force mullipliers

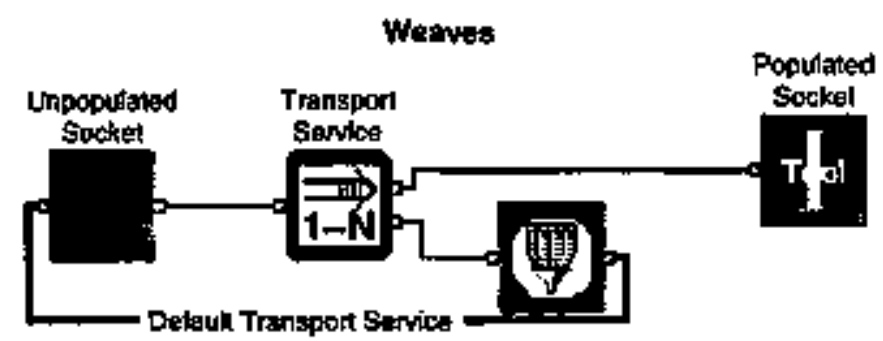

- Weaves are nelworks of injerconnecied tood tragments communicaling thocal or femolid by sending and receivitg objects

- Computalion is structly siparaled Irom communtzalion

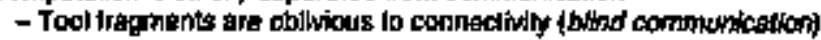

- Puntims recondleguration tol the neturork

- Each toot lraginent nuns in paraliel with other components

- Appditalions characierized ty sireans of dala

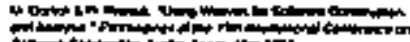




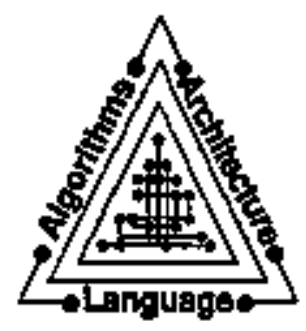

A Portion of a Weave for Siereo Tracking

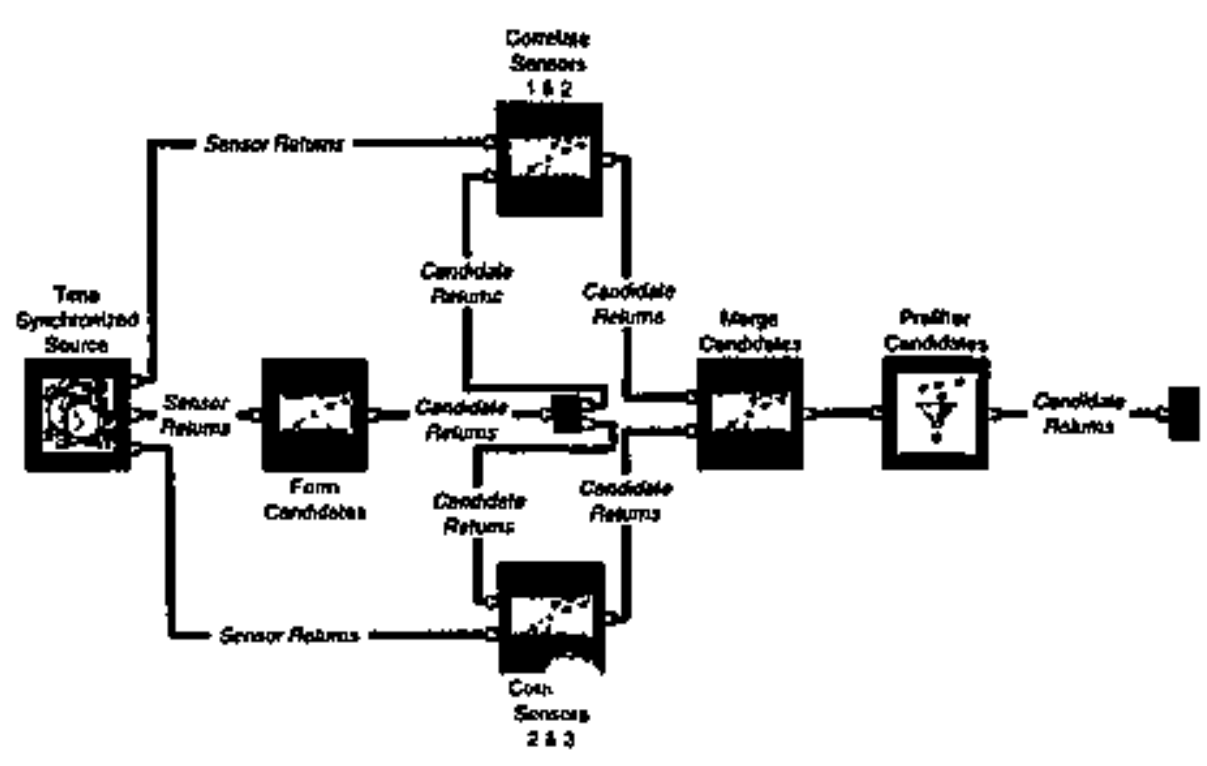

EdIIng the Weave to Insert Instrumintotion

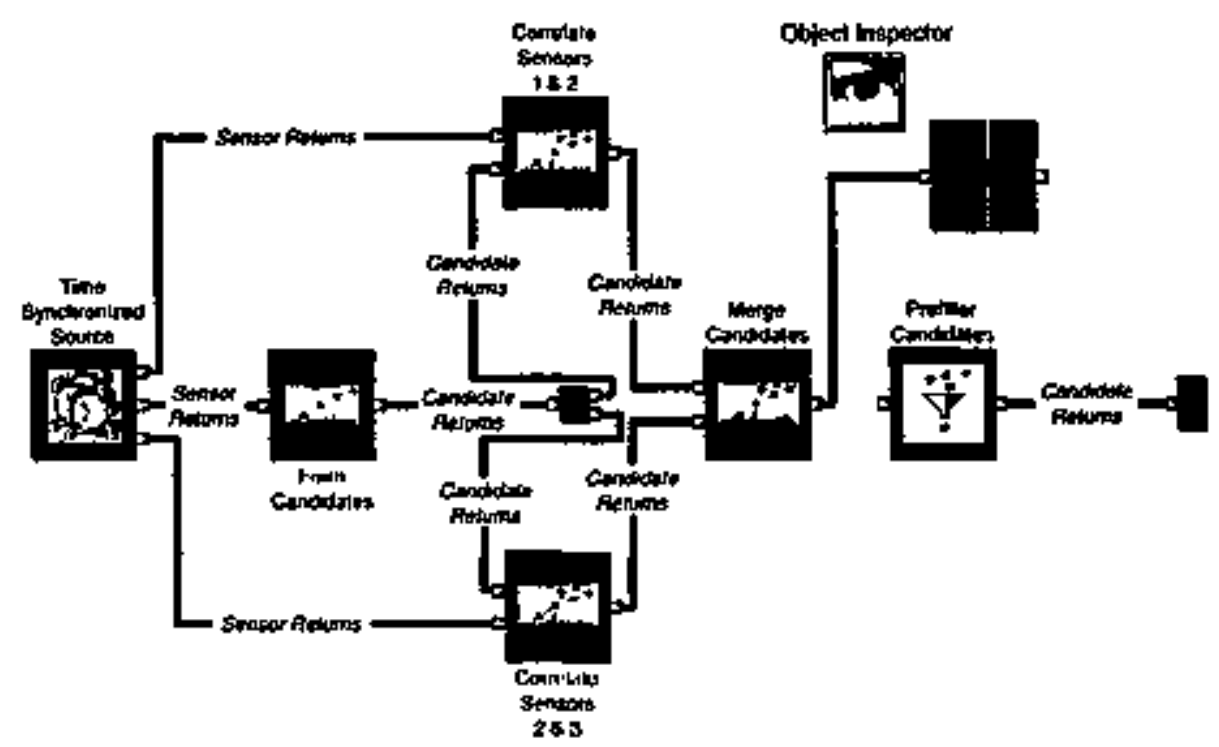




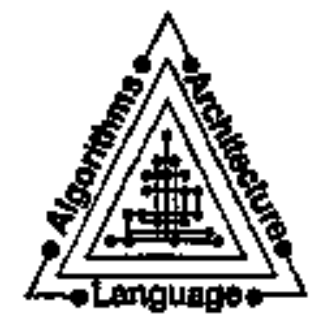

Editing the Weove vo insert tinstrumentetion
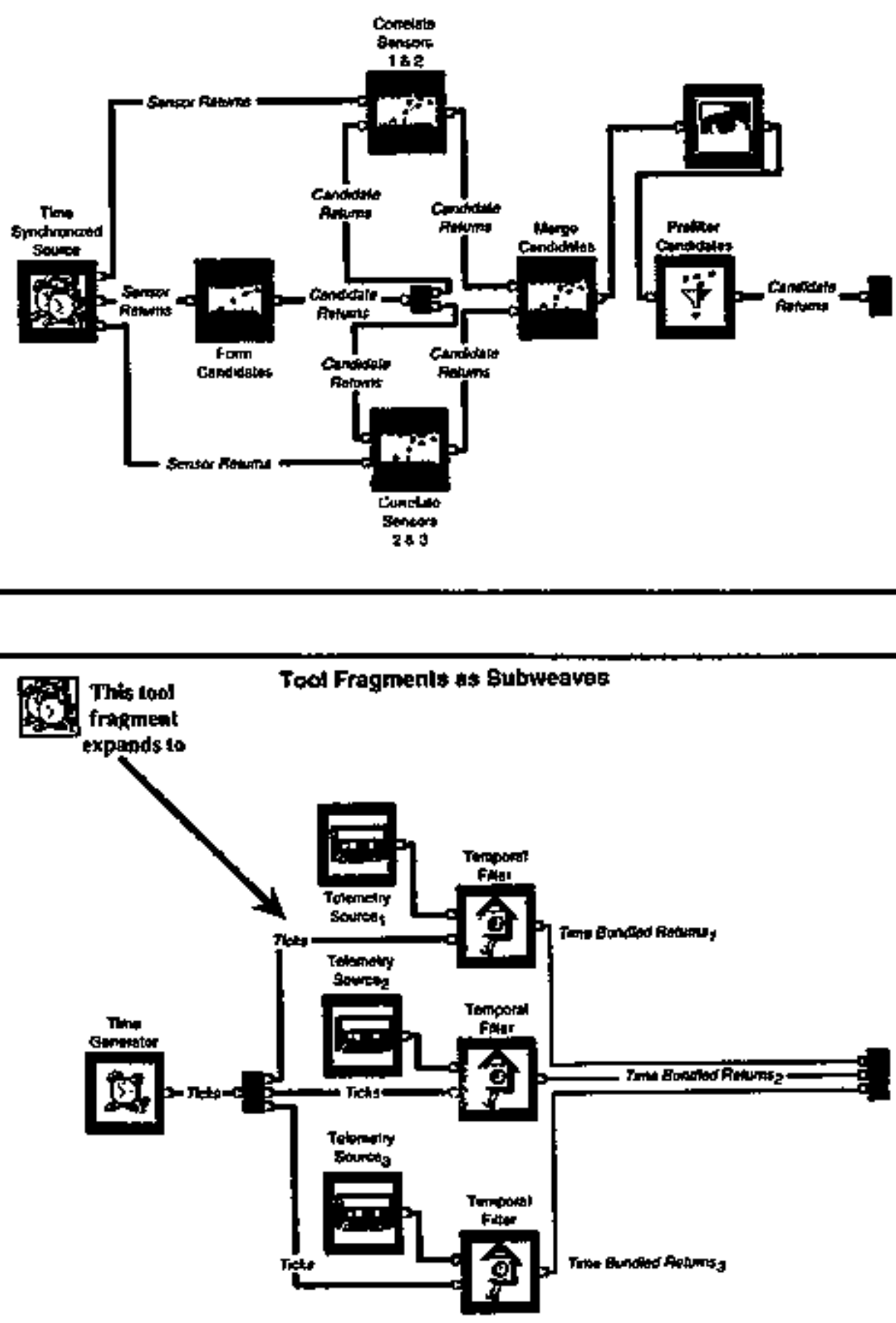


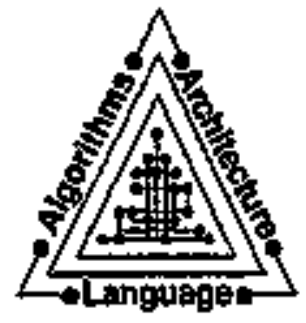

Framework for ProchuceriConsumer

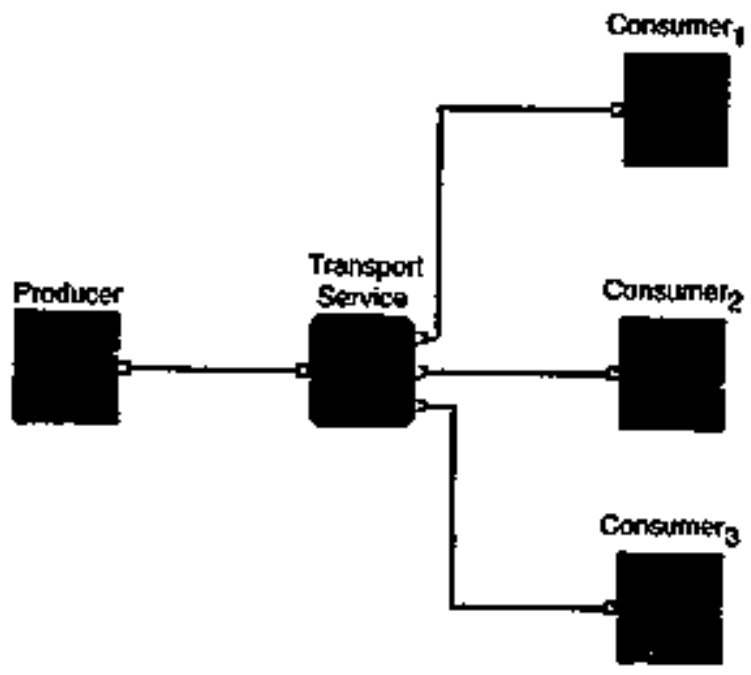

Framework for ProducerfConsumer Relationship
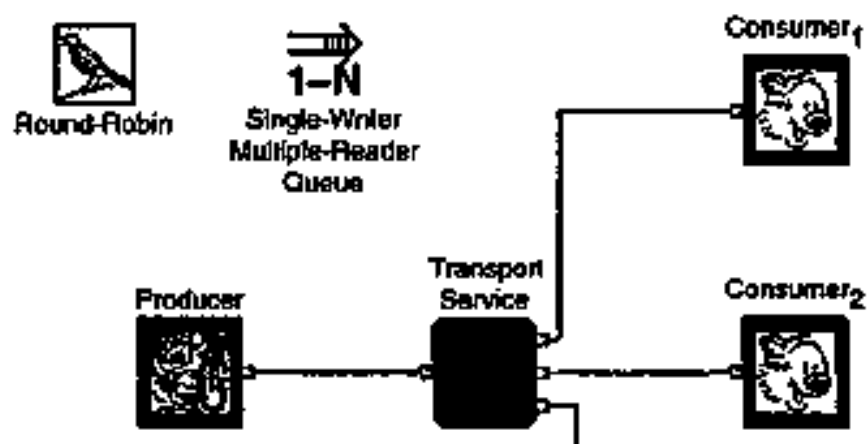

Conswner 3

sis

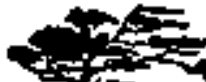




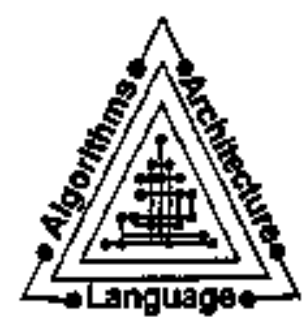

First-Come First-Served Pooducor/Consumer Fielationship

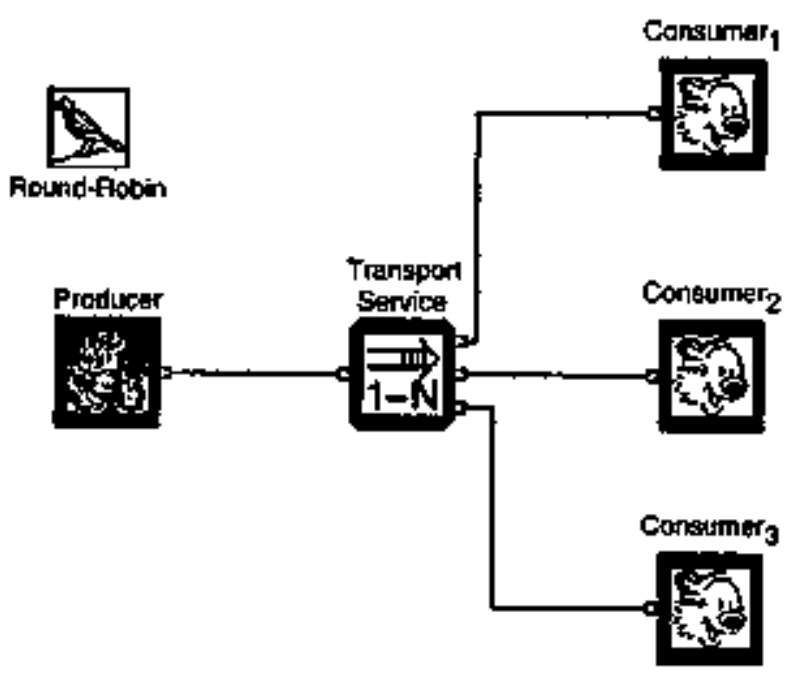

Hound-Robin ProducerfConsumer Rolatlonshlp

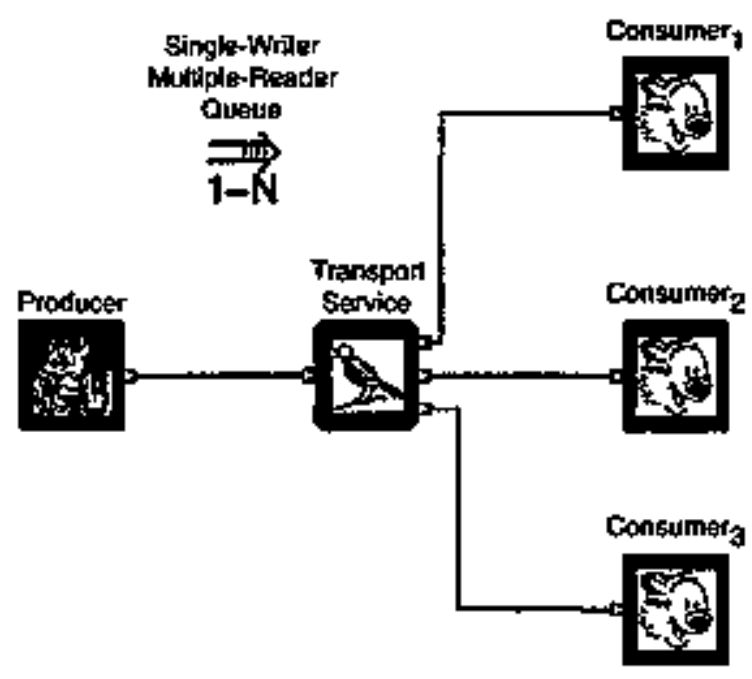




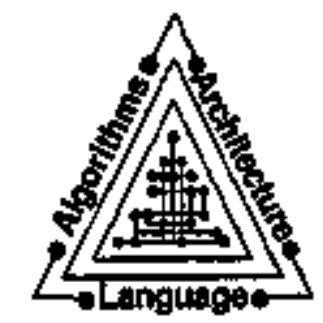

Round-Fobin Transpont Service

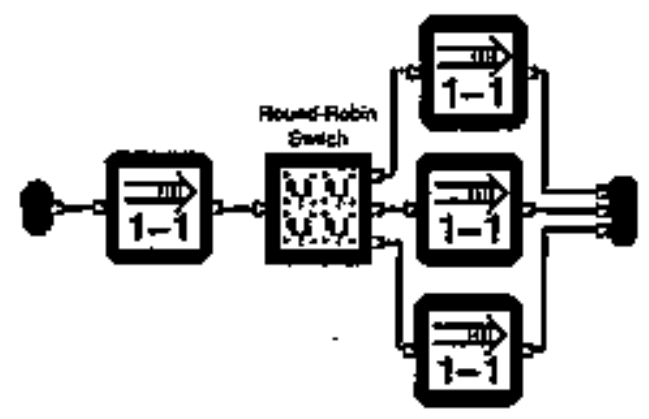

Mlorarchical Software hessage Buses

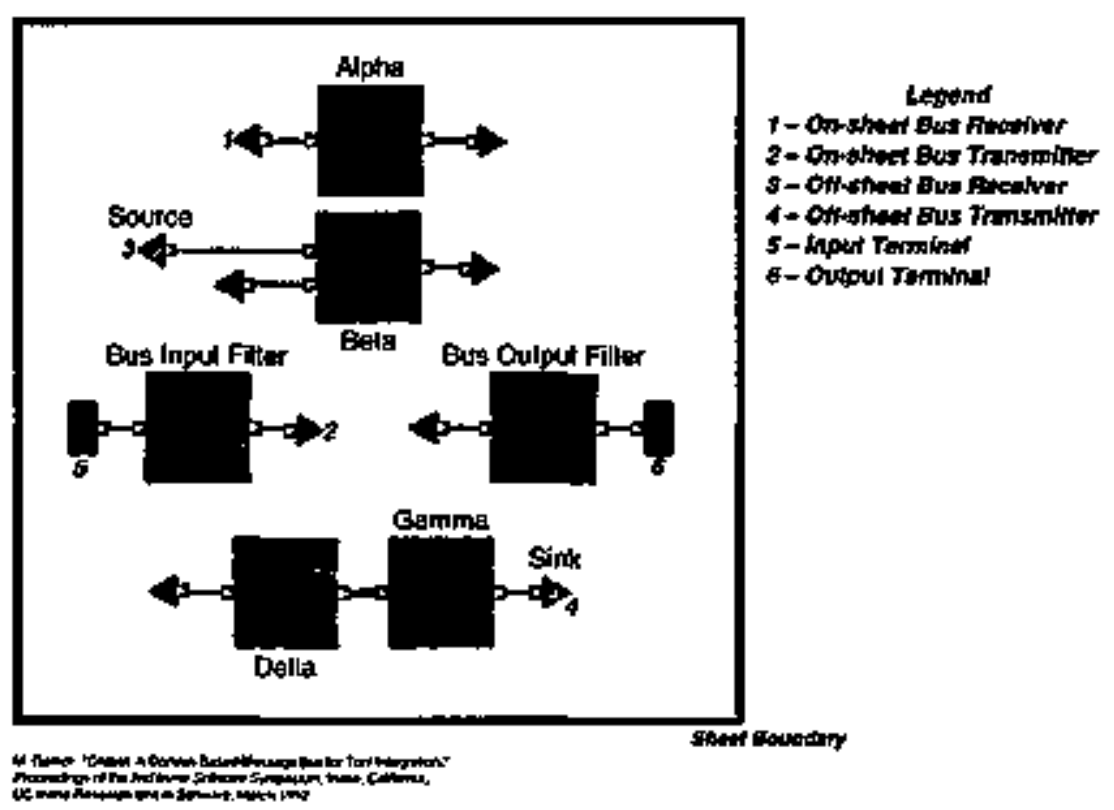




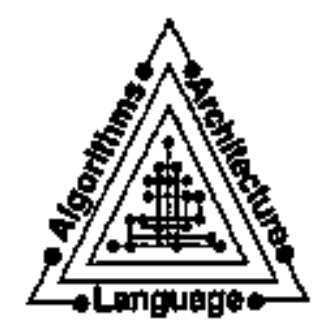

Composilion of Hierarchicad sotware Massage Euses
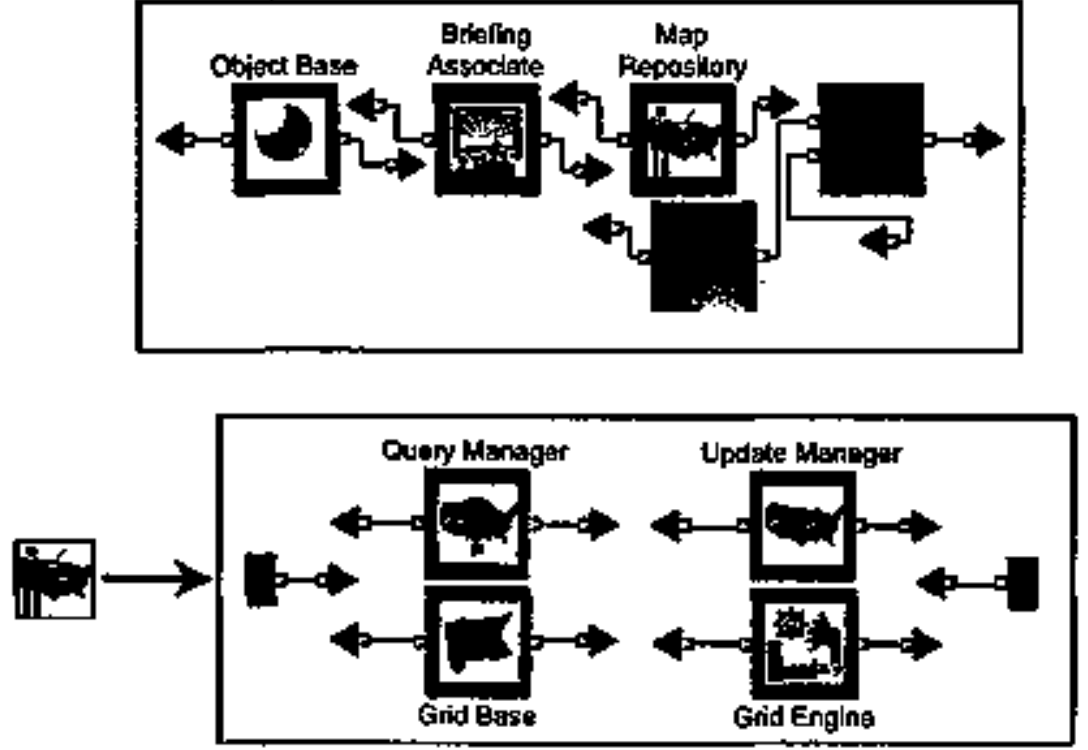

Telescript

- Commenciat product from Eenaral Magic

- Telegcript is to notworking as Posistripl is to pags deseription

- inlerpreted, object-orlented rentake progaramning language

- concepts

-placas

- agants

- traver

- mietings

- Obverse of RPC

don1 send data sand programs instegd

- Daftereft viow of composilion and integralion from weaves

- One possble martiage of the two epproaches is to use Telegcript agentes as woavers

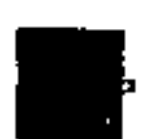

두를

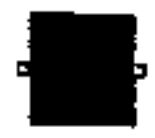

Hi

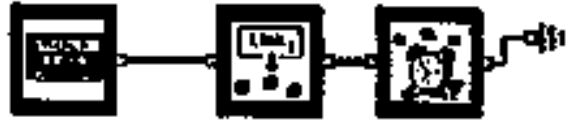

Agent leates with assambled watve

Component hepastiary 


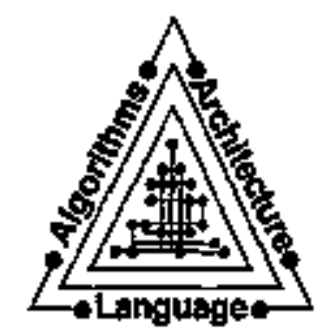

Tostint the Softwore Struptures of the Future

- Tasl early and otion (Debra Richardson)

- spedlcaliens can be altached to weave trameworks and components

+ embedded disectly in the weava

- travel with the Weave

- can be evakualed al wapave construction lime or deteyed umil nunime

- imansparenl spitcing of tesing coonponenls al any Time

- Transpanency ol execultion

- weaves fich in lightweight buthlin tratinumentalkon

- seabinte animation of execulitan

- perkormarea and behavior logging

- Conlinuous selfesting

- essertions

pra- \& post-condlilionts

range chacks

retalionship \& indegrily checks

- robusiness

make the beti of what your hawe and never tail

sale hartors

- Continuous sedFmontioring

- observers can monlior behaver of woave

- Moght reconder

Testing the software Structures of the Futur

- Comilnuous selt-rapark

- isck (BSo Unntx)

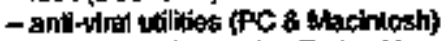

- crypiographle checks (Tfojan Horses)

- scavengers

* conlinualy non in the beckground pollng about in the innerts of a system

- repali inconslstencles and log irouble teports

telephora swttohing systems

network roubers

- High assarance couthponents

- softurare siructures of the fulute wit be highly componenk besed

- "Wied and tuse" componanls

- verilied componenks

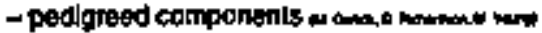

- Tesiling raerilies

- solkwere stuctures wil by highly dynamis

- solhwarg sinutiures and components witi by necessshy be paranold

- you win have no idea of where your sottwara is execuling

- Elgrileand fradion ol processing power wil be devoled lo soll-checing

- cistributed debugging will be the norm 


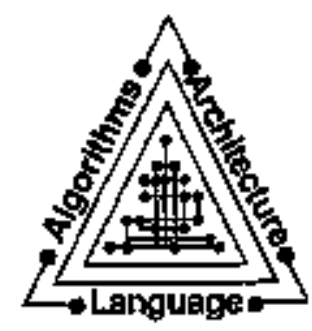

Predictions

Nearterm is going to be very unpleasant in ciequale developorrent methudologies

Iradequale composition mecherisms

inadequala nolwodk lechnology

inadequale esting ineory and mechankes

The information economy is going to steamoller averrone

We ave all goting to be rostikin an ine intomalion sighway

Traditioned softurare methods amount to crimingl negligence

The government and marketplace will demand a new research agenda

Don'l wrile soltware generale il

Don't generate sokwase corripose it

Sothrare as a by-producl of olhar processes

Don'I do II heres when yout ben do II theire 